Energy Systems Environmental Restoration Program ORNL Environmental Restoration Program

\title{
Hydrologic Data Summary for the White Oak Creek Watershed at Oak Ridge National Laboratory, Oak Ridge, Tennessee (January-December 1993)
}

D. M. Borders

D. K. Reece

J. A. Watts

B. J. Frederick

W. L. McCalla

K. S. Ziegler

Date Issued-October 1994

\author{
Prepared by \\ Environmental Sciences Division \\ Oak Ridge National Laboratory \\ ESD Publication 4293
}

Prepared for

U.S. Department of Energy

Office of Environmental Restoration and Waste Management

under budget and reporting code EW 20

Environmental Restoration and Waste Management Programs

Oak Ridge National Laboratory

Oak Ridge, Tennessee 37831 managed by

MARTIN MARIETTA ENERGY SYSTEMS, INC.

for the

U.S. DEPARTMENT OF ENERGY

under contract DE-AC05-84OR21400 


\section{Author Affiliations}

J. A. Watts is a member of the Environmental Sciences Division, Oak Ridge National Laboratory, Martin Marietta Energy Systems, Inc. D. M. Borders and B. J. Frederick are research associates in the Department of Civil Engineering, The University of Tennessee, Knoxville. D. K. Reece and W. L. McCalla are research associates with Analysas Corporation and K. S. Ziegler is with Midwest Technical, Inc. 


\section{DISCLAIMER}

This report was prepared as an account of work sponsored by an agency of the United States Government. Neither the United States Government nor any agency thereof, nor any of their employees, make any warranty, express or implied, or assumes any legal liability or responsibility for the accuracy, completeness, or usefulness of any information, apparatus, product, or process disclosed, or represents that its use would not infringe privately owned rights. Reference herein to any specific commercial product, process, or service by trade name, trademark, manufacturer, or otherwise does not necessarily constitute or imply its endorsement, recommendation, or favoring by the United States Government or any agency thereof. The views and opinions of authors expressed herein do not necessarily state or reflect those of the United States Government or any agency thereof. 


\section{DISCLAIMER}

Portions of this document may be illegible in electronic image products. Images are produced from the best available original document. 


\section{CONTENTS}

FIGURES $\ldots \ldots \ldots \ldots \ldots \ldots \ldots \ldots \ldots \ldots \ldots \ldots \ldots \ldots \ldots \ldots \ldots$

TABLES $\ldots \ldots \ldots \ldots \ldots \ldots \ldots \ldots \ldots \ldots \ldots \ldots \ldots \ldots \ldots \ldots \ldots$ vii

ABBREVIATIONS $\ldots \ldots \ldots \ldots \ldots \ldots \ldots \ldots \ldots \ldots \ldots \ldots \ldots \ldots \ldots \ldots$

ACKNOWLEDGMENTS ......................... xiii

EXECUTTVE SUMMARY $\ldots \ldots \ldots \ldots \ldots \ldots \ldots \ldots \ldots \ldots \ldots \ldots \ldots \ldots$

1. INTRODUCTION $\ldots \ldots \ldots \ldots \ldots \ldots \ldots \ldots \ldots \ldots \ldots \ldots \ldots \ldots \ldots \ldots$

1.1 PURPOSE AND SCOPE $\ldots \ldots \ldots \ldots \ldots \ldots \ldots \ldots \ldots \ldots \ldots \ldots$

1.2 SITE DESCRIPTION $\ldots \ldots \ldots \ldots \ldots \ldots \ldots \ldots \ldots \ldots \ldots \ldots \ldots$

1.3 GEOLOGY AND SOILS ..................... 5

1.4 CONTAMINANTS IN WOC WATERSHED ............. 6

1.5 STATION UPGRADE AND MAINTENANCE .............. 6

1.6 FLOW FREQUENCY ANALYSES ................... 9

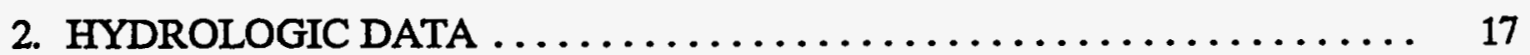

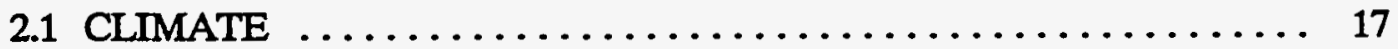

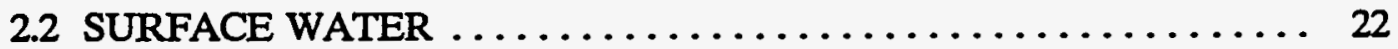

2.2.1 Discharge ........................ 22

2.2.2 Flow Augmentation in the White Oak Creek Watershed ..... 41

2.2.3 Outfalls to the White Oak Creek Flow System ......... 45

2.2.4 Surface Water Quality ................... 45

2.2.5 Contaminants in Sediments ................ 50

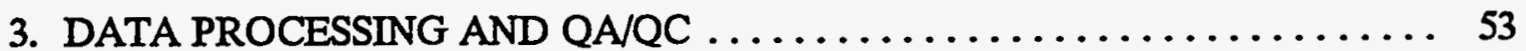

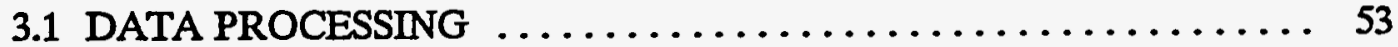

3.1.1 Stream Discharge Data $\ldots \ldots \ldots \ldots \ldots \ldots \ldots \ldots \ldots \ldots \ldots$

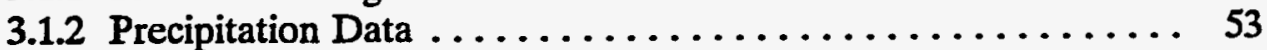

3.1.3 Software Systems $\ldots \ldots \ldots \ldots \ldots \ldots \ldots \ldots \ldots \ldots \ldots \ldots \ldots$

3.2 DATA AVAILABILTTY $\ldots \ldots \ldots \ldots \ldots \ldots \ldots \ldots \ldots \ldots \ldots \ldots \ldots$

3.2.1 Environmental Sciences Division ............... 54

3.2.2 U. S. Department of the Interior, Geological Survey ..... . . 55

3.2.3 Environmental Surveillance Section .............. 55

3.2.4 Oak Ridge Environmental Information System ......... 55

3.3. QUALITY ASSURANCE/QUALITY CONTROL .......... 55

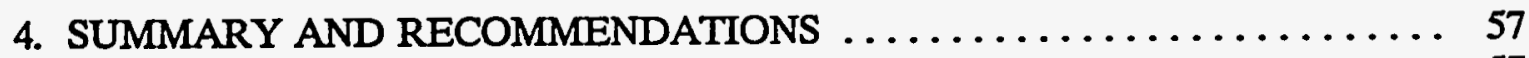

4.1. PROGRESS DURING THE PAST YEAR ............. 57

4.2. RECOMMENDED IMPROVEMENTS $\ldots \ldots \ldots \ldots \ldots \ldots \ldots \ldots . . \ldots 8$

4.2.1 Issues Within the ERP Hydrologic Monitoring Activity . . . . . . 58

4.2.2 Issues for Upper Level Management Approval . . . . . . . . . 59

4.2.3 Future Activities ...................... 60 
APPENDIX A-Daily Precipitation Totals for Stations in the White Oak Creek Watershed

APPENDIX B-Descriptions of Surface Water Monitoring Stations in the White Oak Creek Watershed

APPENDIX C-Daily Streamflow for Surface Water Monitoring Stations in the White Oak Creek Watershed

APPENDIX D-Revisions and Additions to Rating Tables for Surface Water Monitoring Stations in the White Oak Creek Watershed ...........

D-1 


\section{FIGURES}

Page

1 Map of the White Oak Creek Watershed with waste area groupings (WAGs)

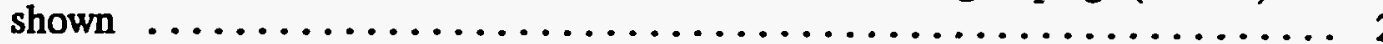

2 White Oak Creek watershed soils classified according to hydrologic soil groups (HSGs)

3 Flow-frequency and flow-volume fraction curves for the White Oak Creek monitoring station (MS3), based on four years of 15-minute discharge data . . 11

4 Flow-frequency and flow-volume fraction curves for the Melton Branch monitoring station (MS4), based on four years of 15-minute discharge data . . 12

5 Flow-frequency and flow-volume fraction curves for the White Oak Dam monitoring station (MS5), based on four years of 15-minute discharge data . . 13

6 Flow-frequency and flow-volume fraction curves for the East Seep monitoring station, based on five years of 15 -minute discharge data . . . . . . . . . 14

7 Flow-frequency and flow-volume fraction curves for the West Seep monitoring station, based on five years of 15 -minute discharge data . . . . . 15

8 Meteorological stations in the White Oak Creek watershed for which data are available through the ORNL/ERP data base systems $\ldots \ldots \ldots \ldots \ldots$

9 Daily precipitation measured at the First Creek (1ST) Creek raingage in the White Oak Creek watershed during the period January-December 1993 . . . 24

10 Daily precipitation measured at the NOAA/ATDD raingage in Oak Ridge during the period January-December $1993 \ldots \ldots \ldots \ldots \ldots \ldots \ldots \ldots$

11 Locations of surface-water monitoring stations in the vicinity of the White Oak Creek watershed . . . . . . . . . . . . . . . . . . . 27

12 Locations of surface-water monitoring stations in the Walker Branch

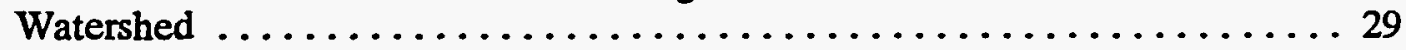

13 Daily streamflow at the White Oak Creek monitoring station (MS3) for the

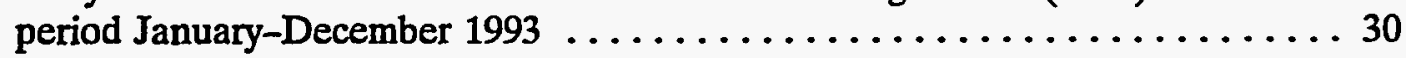

14 Daily streamflow at the Melton Branch monitoring station (MS4) for the period January-December 1993 
15 Daily streamflow at the White Oak Dam monitoring station (MS5) for the

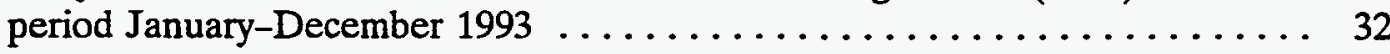

16 Comparison of monthly mean discharge at USGS monitoring station GS3 and ESD monitoring station MS3 $\ldots \ldots \ldots \ldots \ldots \ldots \ldots \ldots \ldots \ldots \ldots$

17 Comparison of monthly mean discharge at ESD monitoring stations MS3,

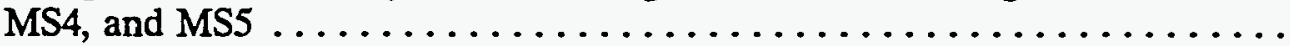

18 Comparison of monthly mean discharge at USGS monitoring station GS6 and ESD monitoring station WOCHW $\ldots \ldots \ldots \ldots \ldots \ldots \ldots \ldots \ldots \ldots$

19 Comparison of monthly mean discharge at USGS monitoring stations GS1, GS3, GS4, and GS5

20 Comparison of monthly mean discharge at USGS monitoring stations GS5 and GS6 ............................... 44

21 Monthly discharge of ${ }^{3} \mathrm{H}$ at NPDES monitoring stations X13 (MS4), X14 (MS3), and X15 (MS5) for the period January-December $1993 \ldots \ldots \ldots \ldots$

22 Monthly discharge of total Sr at NPDES monitoring stations X13 (MS4), X14 (MS3), and X15 (MS5) for the period January-December 1993

23 Monthly discharge of ${ }^{137} \mathrm{Cs}$ at NPDES monitoring stations X13 (MS4), X14 (MS3), and X15 (MS5) for the period January-December 1993 . . . . . . . . 48

24 Monthly discharge of ${ }^{60} \mathrm{Co}$ at NPDES monitoring stations X13 (MS4), X14 (MS3), and X15 (MS5) for the period January-December 1993 


\section{TABLES}

Page

1 Historical changes in the surface of White Oak Lake and major events associated with significant changes in the lake $\ldots \ldots \ldots \ldots \ldots \ldots \ldots$

2 Meteorological stations in the vicinity of the WOC watershed $\ldots \ldots \ldots 18$

3 Rainfall vs frequency for areas up to $25.9 \mathrm{~km}^{2}(10$ miles $)$ in Anderson and Knox counties, Tennessee ........................ 19

4 Precipitation measurement descriptions for raingages located in the vicinity of the WOC watershed and the NOAA/ATDD Oak Ridge station $\ldots \ldots \ldots \ldots 21$

5 Monthly precipitation totals at the WOC watershed and NOAA/ATDD raingages for the period January-December $1993 \ldots \ldots \ldots \ldots \ldots \ldots$

6 Maximum storm event analyses for the 1 ST raingage $\ldots \ldots \ldots \ldots \ldots \ldots$

$7 \quad$ Maximum storm event analyses for the ETF raingage $\ldots \ldots \ldots \ldots \ldots \ldots$

8 Monthly flow and runoff statistics for ESD surface-water monitoring stations located in the vicinity of the WOC watershed $\ldots \ldots \ldots \ldots \ldots \ldots \ldots \ldots$

9 Monthly flow and runoff statistics for USGS surface-water monitoring stations located in the vicinity of the WOC watershed ............... 35

10 Summary of rating tables published in previous 1991 and 1992 Annual Surface Water Hydrology Reports and revisions/additions included in the 1993 Annual Report

A1 Daily precipitation totals at the First Creek (1ST) raingage for the period January-December 1993 . . . . . . . . . . . . . . . . . . . . . . A A-3

A.2 Daily precipitation totals at the Engineering Test Facility (ETF) raingage for the period January-December 1993 . . . . . . . . . . . . . . . . . A-4

A.3 Daily precipitation totals at the SWSA 7 (SW7) raingage for the period January-December $1993 \ldots \ldots \ldots \ldots \ldots \ldots \ldots \ldots \ldots \ldots \ldots \ldots$. . . . . . . .

A4 Daily precipitation totals at the 49-Trench (49T) raingage for the period January-December $1993 \ldots \ldots \ldots \ldots \ldots \ldots \ldots \ldots \ldots \ldots \ldots \ldots$. . . . . . . . . .

A.5 Daily precipitation totals at the SWSA 4 (SW4) raingage for the period January-December 1993 
A6 Daily precipitation totals at the Ish Creek (ISH) raingage for the period January-December $1993 \ldots \ldots \ldots \ldots \ldots \ldots \ldots \ldots \ldots \ldots \ldots \ldots$. A . 8

A.7 Daily precipitation totals at the Walker Branch Watershed (RG1) raingage for the period January-December 1993

A.8 Daily precipitation totals at the Walker Branch Watershed (RG3) raingage for the period January-December $1993 \ldots \ldots \ldots \ldots \ldots \ldots \ldots \ldots \ldots$. A-10

A.9 Daily precipitation totals at the Bear Creek Burial Ground (BUR) raingage for the period January-December 1993

A.10 Daily precipitation totals at the NOAA/ATDD raingage in Oak Ridge for the period January-December $1993 \ldots \ldots \ldots \ldots \ldots \ldots \ldots \ldots \ldots \ldots$. A-12

C.1 Daily streamflow at the White Oak Creek (MS3) monitoring station for the period January-December $1993 \ldots \ldots \ldots \ldots \ldots \ldots \ldots \ldots \ldots \ldots \ldots \ldots \ldots \ldots \ldots$ C-3

C.2 Daily streamflow at the Melton Branch (MS4) monitoring station for the period January-December $1993 \ldots \ldots \ldots \ldots \ldots \ldots \ldots \ldots \ldots \ldots \ldots \ldots \ldots \ldots$ C-4

C.3 Daily streamflow at the White Oak Dam (MS5) monitoring station for the period January-December $1993 \ldots \ldots \ldots \ldots \ldots \ldots \ldots \ldots \ldots \ldots$ C.5

C.4 Daily streamflow at the White Oak Creek Headwaters (WOCHW) monitoring station for the period January-December $1993 \ldots \ldots \ldots \ldots \ldots \ldots \ldots$. C-6

C.5 Daily streamflow at the East Seep monitoring station for the period

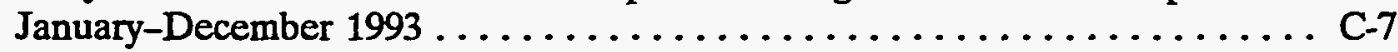

C.6 Daily streamflow at the West Seep monitoring station for the period

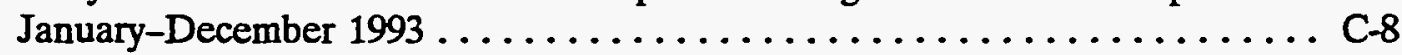

C.7 Daily streamflow at the Raccoon Creek monitoring station for the period January-December 1993 . . . . . . . . . . . . . . . . . . . . . . C-9

C.8 Daily streamflow at the Ish Creek monitoring station for the period January-December $1993 \ldots \ldots \ldots \ldots \ldots \ldots \ldots \ldots \ldots \ldots \ldots \ldots$. C-10

C.9 Daily streamflow at the Walker Branch East weir (WBE) monitoring station for the period January-December $1993 \ldots \ldots \ldots \ldots \ldots \ldots \ldots \ldots$ C-11

C.10 Daily streamflow at the Walker Branch West weir (WBW) monitoring station for the period January-December $1993 \ldots \ldots \ldots \ldots \ldots \ldots \ldots \ldots \ldots$ C-12

C.11 Daily streamflow at monitoring station GS1 (USGS 03536450) for the period January-December 1993 ... 
C.12 Daily streamflow at monitoring station GS2 (USGS 03537100) for the period January-December 1993 . . . . . . . . . . . . . . . . . . . . . .

C.13 Daily streamflow at monitoring station GS3 (USGS 03536550) for the period January-December 1993 . . . . . . . . . . . . . . . . . . . . . . . . . C-15

C.14 Daily streamflow at monitoring station GS4 (USGS 03536440) for the period January-December 1993 . . . . . . . . . . . . . . . . . . . . . . . . . C-16

C.15 Daily streamflow at monitoring station GS5 (USGS 03536380) for the period January-December 1993 . . . . . . . . . . . . . . . . . . . C-17

C.16 Daily streamflow at monitoring station GS6 (USGS 03536320) for the period January-December $1993 \ldots \ldots \ldots \ldots \ldots \ldots \ldots \ldots \ldots \ldots \ldots \ldots$. . . . . . . . . . . .

C.17 Daily streamflow at monitoring station GS16 (USGS 03537050) for the period January-September 1993 . . . . . . . . . . . . . . . . . . . . . . C-19

C.18 Daily streamflow at monitoring station GS17 (USGS 03537200) for the period January-September 1993 . . . . . . . . . . . . . . . . . . . . . . . . . . . C-20

C.19 Daily streamflow at monitoring station GS18 (USGS03537300) for the period January-September 1993

D.15 Rating table for the critical-flow flume at the First Creek monitoring station (GS1, USGS 03536450) located above the confluence with Northwest

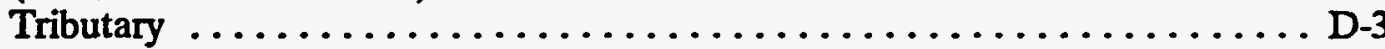

D.18 Rating table for the short-crested V-notch weir at the Northwest Tributary monitoring station (GS4, USGS 03536440) located above the confluence with First Creek . . . . . . . . . . . . . . . . . . . . . . . D 6

D.22 Rating table for the $\mathrm{H}$-flume at the Center Seven Tributary monitoring station (GS17, USGS 03537200) located on the center tributary to Melton Branch

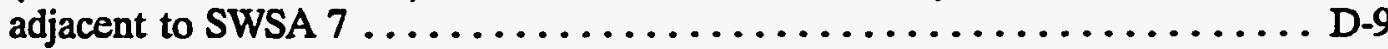

D.25 Rating table for the V-notch East and West Fork weirs on Walker Branch located in the Walker Branch Watershed 



\section{ABBREVIATIONS}

\begin{tabular}{|c|c|}
\hline 1ST & First Creek raingage \\
\hline ATDD & Atmospheric Turbulence and Diffusion Division \\
\hline BMAP & Biological Monitoring and Abatement Program \\
\hline cfs & cubic feet per second \\
\hline CYRTF & Coal Yard Runoff Treatment Facility \\
\hline CWHMP & Comprehensive Watershed Hydrologic Monitoring Program \\
\hline $\mathrm{DCP}$ & Data Collection Platform \\
\hline DOE & Department of Energy \\
\hline ECE & Environmental Consulting Engineers \\
\hline EPA & Environmental Protection Agency \\
\hline ERMA & Environmental Restoration Monitoring and Assessment \\
\hline ERP & Environmental Restoration Program \\
\hline ESD & Environmental Sciences Division \\
\hline ESP & East Seep monitoring station \\
\hline ESPS & Environmental Surveillance and Protection Section \\
\hline ETF & Engineering Test Facility \\
\hline FY & Fiscal Year \\
\hline GIS & Geographic Information System \\
\hline HFIR & High Flux Isotope Reactor \\
\hline HRT & Homogenous Reactor Test \\
\hline HSG & Hydrologic Soil Group \\
\hline LLW & Low Level Waste \\
\hline MB (MBR) & Melton Branch \\
\hline MSL & Mean Sea Level \\
\hline MS & Monitoring Station \\
\hline MSS & multispectral scanning \\
\hline NOAA & National Oceanic and Atmospheric Administration \\
\hline NPDES & National Pollutant Discharge Elimination System \\
\hline NRWTF & Non-Radiological Wastewater Treatment Facility \\
\hline NWT & Northwest Tributary \\
\hline OECD & Office of Environmental Compliance and Documentation \\
\hline OREIS & Oak Ridge Environmental Information System \\
\hline ORNL & Oak Ridge National Laboratory \\
\hline ORR & Oak Ridge Reservation \\
\hline PCB & Polychlorinated Biphenyl \\
\hline PWTP & Process Waste Treatment Plant \\
\hline QA/QC & Quality Assurance/Quality Control \\
\hline RCRA & Resource Conservation and Recovery Act \\
\hline RFI & RCRA Facility Investigation \\
\hline SI & Site Investigation \\
\hline STP & Sewage Treatment Plant \\
\hline SWSA & Solid Waste Storage Area \\
\hline TRU & Transuranics or Transuranium Processing Facility \\
\hline USGS & United States Geological Survey \\
\hline WAG & Waste Area Grouping \\
\hline
\end{tabular}




$\begin{array}{ll}\text { WBE } & \text { Walker Branch East Fork } \\ \text { WBW } & \text { Walker Branch West Fork } \\ \text { WOC } & \text { White Oak Creek } \\ \text { WOCE } & \text { White Oak Creek Embayment } \\ \text { WOCHW } & \text { White Oak Creek Headwater } \\ \text { WOD } & \text { White Oak Dam } \\ \text { WOL } & \text { White Oak Lake } \\ \text { WSP } & \text { West Seep monitoring station }\end{array}$




\section{ACKNOWLEDGEMENTS}

The authors wish to acknowledge the technical review and helpful suggestions of Scott M. Gregory and Telena D. Moore. Several others provided information or guidance for this report in many ways. We thank all of them. Without their assistance, this report would have been difficult to prepare. 



\section{EXECUTIVE SUMMARY}

This report summarizes, for the 12-month period (January through December 1993), the available dynamic hydrologic data collected, primarily, on the White Oak Creek (WOC) watershed along with information collected on the surface flow systems which affect the quality or quantity of surface water. The collection of hydrologic data is one component of numerous, ongoing Oak Ridge National Laboratory (ORNL) environmental studies and monitoring programs and is intended to:

1. characterize the quantity and quality of water in the flow system,

2. assist with the planning and assessment of remedial action activities,

3. provide long-term availability of data and quality assurance, and

4. support long-term measures of contaminant fluxes at a spatial scale to provide a comprehensive picture of watershed performance that is commensurate with future remedial actions.

Characterization of the hydrology of the WOC watershed provides a better understanding of the processes which drive contaminant transport in the watershed. Identification of spatial and temporal trends in hydrologic parameters and mechanisms that affect the movement of contaminants supports the development of interim corrective measures and remedial restoration alternatives. In addition, hydrologic monitoring supports long-term assessment of the effectiveness of remedial actions in limiting the transport of contaminants across Waste Area Grouping (WAG) boundaries and ultimately to the off-site environment. For these reasons, it is of paramount importance to the Environmental Restoration Program (ERP) to collect and report hydrologic data, an activity that contributes to the Site Investigations (SI) component of the ERP.

This report provides and describes sources of hydrologic data for Environmental Restoration activities that use monitoring data to quantify and assess the impact from releases of contaminants from ORNL WAGs. The majority of the data summarized in this report are available from the Oak Ridge Environmental Information System (OREIS). Surface-water data available within the WOC flow system include discharge and runoff and surface water quality. Climatological data available for the Oak Ridge area include precipitation, temperature, relative humidity, wind speed and wind direction, pan evaporation, and solar radiation. Anomalies in the data and problems with monitoring and accuracy are discussed. Appendices contain daily precipitation measurements, daily discharge at surface-water monitoring stations, descriptions of surface-water monitoring stations located in the vicinity of the WOC watershed, and rating table updates for hydraulic control structures that have been recalibrated since the last report. In addition, the rating table for the East Fork and West Fork weir of Walker Branch Watershed has been included in this report. 


\section{INTRODUCTION}

This report, prepared as part of the Environmental Restoration Program (ERP) at the Oak Ridge National Laboratory (ORNL), is the sixth in a series of reports that summarize the hydrologic data collected on and in the vicinity of the White Oak Creek (WOC) watershed (Fig. 1). White Oak Creek drains the ORNL and receives radioactive and nonradioactive effluents (treated and untreated) from Laboratory activities as well as leachates from subsurface waste storage areas in use since the early 1940s. Sherwood and Loar (1986) summarized the available information on hydrogeological and ecological characteristics of the WOC flow system and the nature and quantity of contaminants released into and from the system. Previous annual summaries of hydrologic data (i.e., Borders et al. 1989, 1991, 1992, 1993) were prepared in response to Sherwood and Loar's (1986) recommendation that the hydrology of the WOC watershed be characterized in order to better understand trends in both temporal and spatial patterns of the watershed.

The collection of hydrologic data is an integral component of numerous ongoing ORNL environmental studies and monitoring programs and is designed to help (1) characterize the quantity and quality of water in the flow system, (2) plan and assess remedial action activities, (3) provide long-term data availability and quality assurance, and (4) support long-term measures of contaminant fluxes at a spatial scale to provide a comprehensive picture of watershed performance that is commensurate with future remedial actions. This report continues the characterization and provides the sources of data needed for long-term assessment of the effectiveness of remedial and restoration activities.

\subsection{PURPOSE AND SCOPE}

This report documents hydrologic data collected in the vicinity of the WOC watershed for the period January 1 through December 31, 1993. Available dynamic hydrologic data collected during 1993, along with information collected on the surface flow systems which affect the quantity or quality of surface water, are summarized. In addition to presenting data collected during the past year, we have attempted to summarize data collected over several years to show trends in both spatial and temporal scales.

\subsection{SITE DESCRIPTION}

The WOC watershed is located primarily in the Roane County portion of the Oak Ridge Reservation. The headwaters region of WOC, making up the northeast corner of the watershed, lies partially in Anderson County. The WOC watershed is bounded by Copper Ridge to the south, White Wing Road (State Highway 95) to the west, Chestnut Ridge to the north, and approximately the Roane/Anderson County boundary to the east. The majority of ORNL's facilities, active and inactive waste management areas, and potential sources of contaminants lie within the watershed boundaries. Therefore, most waste effluents produced as a result of ORNL operations are released into the WOC system.

WOC rises from springs on the southwest slopes of Chestnut Ridge and, with its tributaries, drains much of Bethel and Melton Valleys (which include ORNL) to the Clinch 


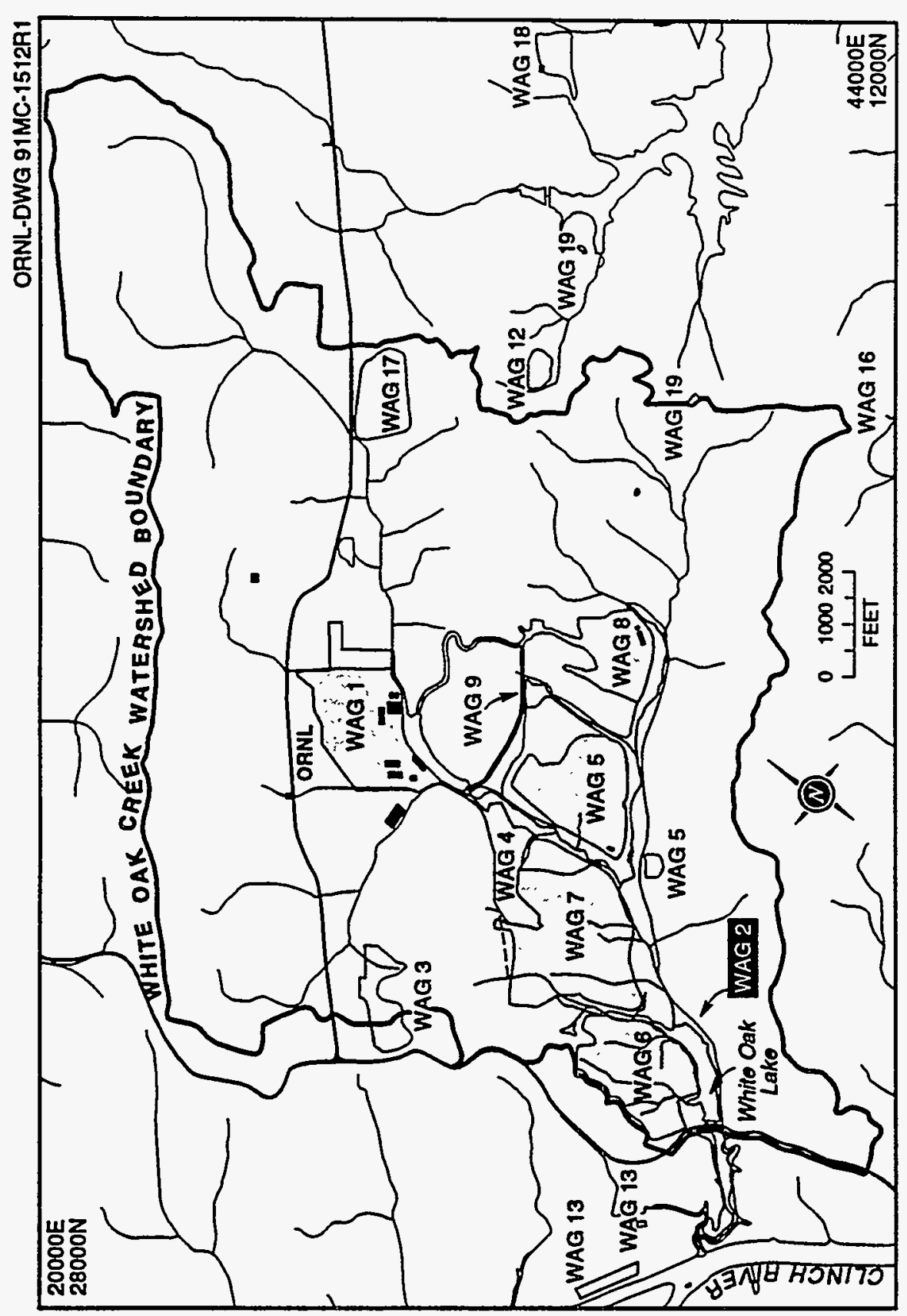

焉 
River. The waters of WOC are impounded by White Oak Dam (WOD), constructed $1.0 \mathrm{~km}$ (0.6 miles) upstream from the Clinch River in 1943, to form White Oak Lake (WOL) which serves as a holding pond for ORNL waste effluents. The drainage areas upstream from the Clinch River and WOD are approximately $16.8 \mathrm{~km}^{2}\left(6.5 \mathrm{miles}^{2}\right)$ and $16.0 \mathrm{~km}^{2}\left(6.15 \mathrm{miles}^{2}\right)$, respectively (Martin Marietta Energy Systems, Inc. 1985). Elevations in the watershed range from $226 \mathrm{~m}$ (741 ft) mean sea level (MSL) at the mouth of WOC to $413 \mathrm{~m}$ (1355 ft) MSL at the top of Melton Hill, the highest point on the Oak Ridge Reservation (McMaster 1963; McMaster and Waller 1965).

Since WOL was created in 1943, a number of studies have been undertaken to determine contaminant sources, quantities of contaminants released into and retained in the lake, and the geology and hydrogeology of WOC/WOL. Table 1 summarizes some of the more important studies conducted since 1945. In some instances, the references in Table 1 represent summaries of the information; individual investigators have reported in greater detail their efforts in other reports and papers.

White Oak Dam is a low-head structure with a normal lake elevation of $227.1 \mathrm{~m}(745 \mathrm{ft})$.

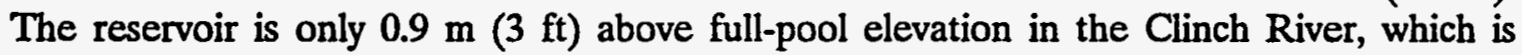
$226.6 \mathrm{~m}$ (742 ft). Cox et al. (1991) indicated that the volume of WOL at normal pool level was approximately $43,890 \mathrm{~m}^{3}\left(1,546,330 \mathrm{ft}^{3}\right)$ in the summer of 1988 . This effort has tentatively been scheduled to be repeated later in Fiscal Year (FY) 1994 as part of the Waste Area Grouping (WAG) 2 program. Flow from WOL discharges through a weir and concretebox culvert to the lower reach of WOC. In 1983, the flow system at the dam was modified to increase flood discharge capacity to approximately $56.6 \mathrm{~m}^{3} / \mathrm{s}\left(2000 \mathrm{ft}^{3} / \mathrm{s}\right)$. Tschantz (1987) estimated the 100-year flood peak discharge to be approximately $44.6 \mathrm{~m}^{3} / \mathrm{s}\left(1574 \mathrm{ft}^{3} / \mathrm{s}\right)$.

Until recently, backwater from the Clinch River created an embayment in WOC below WOD only when the Watts Bar Reservoir was near full pool level (approximately April to October). The WOC Embayment (WOCE) extends $1 \mathrm{~km}(0.6 \mathrm{mi})$ downstream from WOD to its mouth at Clinch River kilometer 33.5 (Clinch River mile 20.8). Water levels and flow in the WOCE were largely controlled by the operation of Melton Hill Dam $(3.7 \mathrm{~km}$ [2.3 miles] upstream on the Clinch River) and summer and winter pool levels on Watts Bar Reservoir, formed by Watts Bar Dam ( $94 \mathrm{~km}$ [58.8 miles] downstream on the Tennessee River). When the generators at Melton Hill Dam are operating, the release of water from the dam can increase the depth of water at the mouth of the embayment by over $0.3 \mathrm{~m}(1 \mathrm{ft})$ in two minutes. When the generators shut down, the water level drops almost as quickly. This rapid change in water level and pulsing of flow caused by daily peaking operations at Melton Hill Dam were contributing to the erosion of sediments from the embayment. Water levels typically vary by approximately $0.6-1.2 \mathrm{~m}(2-4 \mathrm{ft})$ per day, with monthly ranges up to $2.5 \mathrm{~m}(8 \mathrm{ft})$ or more.

A sediment retention structure, constructed at the mouth of WOC on the Clinch River, was completed in April 1992. It was constructed to reduce the scour of contaminated sediments in the WOCE. The spillway of the retention structure consists of sheet pile coffer cells constructed to an elevation of $738 \mathrm{ft}$ MSL with gabions on top of the cells to elevation $743 \mathrm{ft}$ MSL. This limits the winter drawdown in the embayment to an elevation greater than $738 \mathrm{ft}$ MSL, resulting in a year-round embayment below WOD. The gabions form a 
Table 1. Historical changes in the surface of White Oak Lake and major events associated with significant changes in the lake

\begin{tabular}{|c|c|c|c|}
\hline DATE & $\begin{array}{l}\text { SURFACE } \\
\text { AREA (ha) } \\
\end{array}$ & EVENTS & REFERENCES \\
\hline 1941 & NA & Highway fill and culvert installed by TVA & Smith (1945) as in Krumholz (1954a) \\
\hline 1943 & 14.5 & $\begin{array}{l}\text { (a) Sheet piling dam installed with spillway with vertical sliding gate; (b) Generation of } \\
\text { radioactive waste at ORNL began and lake served as final settling basin ( } 750 \mathrm{ft} \mathrm{MSL)}\end{array}$ & $\begin{array}{l}\text { (a) Krumholz (1954b,c); (b) Clinch } \\
\text { River Study Steering Committee (1967) }\end{array}$ \\
\hline 1944 & NA & Dikes at WOC $\mathrm{km} 3.3$ and 3.9 washed out ( 7.75 in., $26 \mathrm{~h}, 3.5$ in. runoff) & Setter and Kochtitsky (1950) \\
\hline 1945 & 12.2 & Investigation of structural strength of dam (746.5 fi) & Oakes et al. (1982) \\
\hline 1948 & 10.3 & $\begin{array}{l}\text { Lake lowered to } 745.5 \mathrm{ft} \text { to facilitate sediment sampling, normal operation from } 1948 \text { to } \\
1955 \text { varied from } 747-749 \mathrm{ft} \text { ) }\end{array}$ & Oakes et al. (1982) \\
\hline 1953 & NA & Lake partially drained during rotenone survey of fish populations & Oakes et al. (1982) \\
\hline 1955 & 2.8 & $\begin{array}{l}\text { Lake drained; radionuclides in lake sediment and water believed to be in equilibrium so } \\
\text { lake served no useful function in retaining radioactivity but could function as an } \\
\text { emergency storage basin. }\end{array}$ & $\begin{array}{l}\text { Clinch River Study Steering Committee } \\
\text { (1967) }\end{array}$ \\
\hline 1956 & 0.4 & $\begin{array}{l}\text { Significant releases of }{ }^{137} \mathrm{Cs} \text { probably from erosion of freshly exposed sediment after lake } \\
\text { was drained. }\end{array}$ & Lackey (1957) \\
\hline 1959 & NA & Gate structure renovated to prevent inflow of backwaters from Clinch River & $\begin{array}{l}\text { Clinch River Study Steering Committee } \\
\text { (1967) }\end{array}$ \\
\hline 1960 & 3.2 & Dam closed, surface level raised & Kolehmainen and Nelson (1969) \\
\hline 1963 & 6.0 & Completion of Melton Hill Dam & Kolehmainen and Nelson (1969) \\
\hline 1967 & 8.1 & None reported & McMaster (1967) \\
\hline 1969 & 10.5 & None reported & Kolehmainen and Nelson (1969) \\
\hline 1979 & 4.6 & Lake level gradually dropped from 745 to $742 \mathrm{ft}$ due to potential instability of the dam & Oakes et al. (1982) \\
\hline 1980 & 6.9 & Construction of a berm to stabilize dam was completed & Boyle et al. (1982) \\
\hline 1983 & 6.9 & Discharge channel and weir constructed, roadbed rerouted & \\
\hline 1988 & 6.9 & Estimate of surface area and volume $\left(43,900 \mathrm{~m}^{3}\right)$ at lake level of $745 \mathrm{ft}$ & Cox et al. (1991) \\
\hline 1992 & 6.9 & Sediment retention structure constructed at mouth of WOC on the Clinch River & \\
\hline
\end{tabular}


permeable crest intended to attenuate the rapid rise and drawdown resulting from the diurnal pulsing of Melton Hill Dam.

\subsection{GEOLOGY AND SOILS}

Four major geologic units underlie the WOC drainage basin. All formations strike northeast at about $56^{\circ}$ and dip southeast at angles between $30^{\circ}$ and $40^{\circ}$. The Knox Group (Cambrian and Ordovician Age) underlies Chestnut and Copper Ridges, which bound the WOC drainage basin to the north and south. The Knox Group, mostly composed of cherty dolomite in which sinkholes and caverns have developed, is the principal water-bearing formation in the watershed. The springs along the southern slopes of Chestnut Ridge are the principal sources of the base flow in the upper portion of WOC (McMaster and Waller 1965).

The Chickamauga Group (Ordovician Age) underlies Bethel Valley, where the ORNL Main Plant area, and Solid Waste Storage Areas (SWSAs) 1, 2, and 3 are located. This formation is primarily limestone, interbedded with shales, siltstones, and bedded chert. Generally, the strata are thin- to medium- bedded. Solution openings and fractures occur in the Chickamauga, but the openings are smaller than in the Knox Group.

The Conasauga Group (Cambrian Age) underlies Melton Valley, where SWSAs 4, 5, and 6 , and the pits and trenches area are located. The stratigraphic sequence through the Conasauga formation is gradational, from shale at its base to bedded limestone at the top. WOL and the lower part of WOC rest on limestone or shaley limestone of the Conasauga Group.

The Rome Formation (Cambrian Age) is exposed along Haw Ridge. This formation consists of sandstone, shale, siltstone and locally, dolomite.

The Knox Group and the underlying Maynardville Limestone of the Consauga Group form the Knox aquifer (Solomon et al. 1992), which is the source of most natural base flow in streams in the WOC basin.

The Rome Formation, the Conasauga Group and the Chickamauga Group discharge smaller quantities of water to the streams. Water is found in weathered rock of all units near land surface.

The soils of Roane County were mapped in the 1930s and the results were published in 1942 (Swann et al. 1942). Tschantz and Rghebi (1989) analyzed soil survey maps of Roane and Anderson Counties and identified approximately 40 different soil groups in the WOC watershed. The soils, most of silty or very fine loam texture, fall into three of the four major hydrologic soil groups (HSGs).

Soils categorized into the four hydrologic soil groups are denoted by the letters A, B, C, and $\mathrm{D}$. Soils in the A group have high infiltration rates. They are chiefly deep, well drained sands or gravels with low runoff potential. Soils in the B group have moderate infiltration rates. They are mostly moderately deep, well drained soils of moderately fine to moderately course texture. Soils in group $\mathrm{C}$ have slow infiltration rates. They are mostly moderately 
deep, well-drained soils of moderately fine to moderately course texture. Soils in group D have very slow infiltration rates and a high runoff potential. They are chiefly clay soils with a high swelling potential, soils with a permanently high water table, soils with a clay pan at or near the surface, and shallow soils over nearly impervious materials.

Soils in the WOC watershed are clustered into six broad bands running east to west (ORNL grid) (Fig. 2). Soils are distributed in the watershed as follows: $54.1 \%$ of the watershed area is HSG B, $20.0 \%$ is HSG C, and $25.9 \%$ is HSG D. Therefore, the natural soils of the watershed, in both Bethel and Melton Valleys, have relatively slow infiltration rates and tend to yield relatively high runoff.

\subsection{CONTAMINANTS IN THE WOC WATERSHED}

Water in WOL contains measurable quantities of dissolved ${ }^{3} \mathrm{H}$ and ${ }^{90} \mathrm{Sr}$, which are released through the monitoring station at WOD. Controlled releases of ORNL treated and untreated effluents to WOC include those from the Process Waste Treatment Plant (PWTP), the Sewage Treatment Plant (STP), the Coal Yard Runoff Treatment Facility (CYRTF), and a variety of process waste holding ponds scattered throughout the ORNL complex. The PWTP effluent goes to the Non-Radiological Wastewater Treatment Facility (NRWTF) before being discharged into WOC. The WOC flow system also receives effluent through both surface and groundwater flow from nonpoint sources, the SWSAs and low level waste (LLW) pits and trenches. Sediments within the WOC flow system have sorbed chemical and radioactive contaminants and have accumulated in the WOC floodplain and WOL. Oakes et al. (1982) estimated that approximately $5 \times 10^{6} \mathrm{ft}^{3}$ of contaminated sediment had collected in the lake bed since 1943. The sediment in the lake bed contains an estimated $650 \mathrm{Ci}$ of radioactive isotopes, primarily ${ }^{137} \mathrm{Cs},{ }^{60} \mathrm{Co}$, and ${ }^{90} \mathrm{Sr}$. These estimates will be revised according to the results of efforts by the WAG 2/SI program to be conducted in FY 1994 and beyond. During periods of heavy runoff, dissolved radionuclides and resuspended and new suspended, contaminated sediment are released from the lake into the WOCE and the Clinch River.

\subsection{STATION UPGRADE AND MAINTENANCE}

The integrity of the system that monitors surface water discharge on the WOC watershed has been deteriorating for several years due to the unmitigated deposition of sediments in stilling pools, inadequate design and lack of calibration of engineered flow measurement devices, and general lack of a consistent and comprehensive monitoring station and channel maintenance program. This section addresses the problems encountered in monitoring surface-water discharge and collecting data at sites in the WOC watershed and vicinity. Accurate, continuous discharge measurements are critical to the ERP's goal of quantifying and characterizing contaminant discharges from waste sites at ORNL for future remedial actions.

In the early 1980s, the primary surface-water monitoring stations on WOC and Melton Branch (MB), above their confluence, and at WOD, were upgraded (redesigned) for improved discharge measurements and water quality sampling. At each site, the engineered hydraulic control (i.e., flow measurement structure) consists of separate low-flow and 


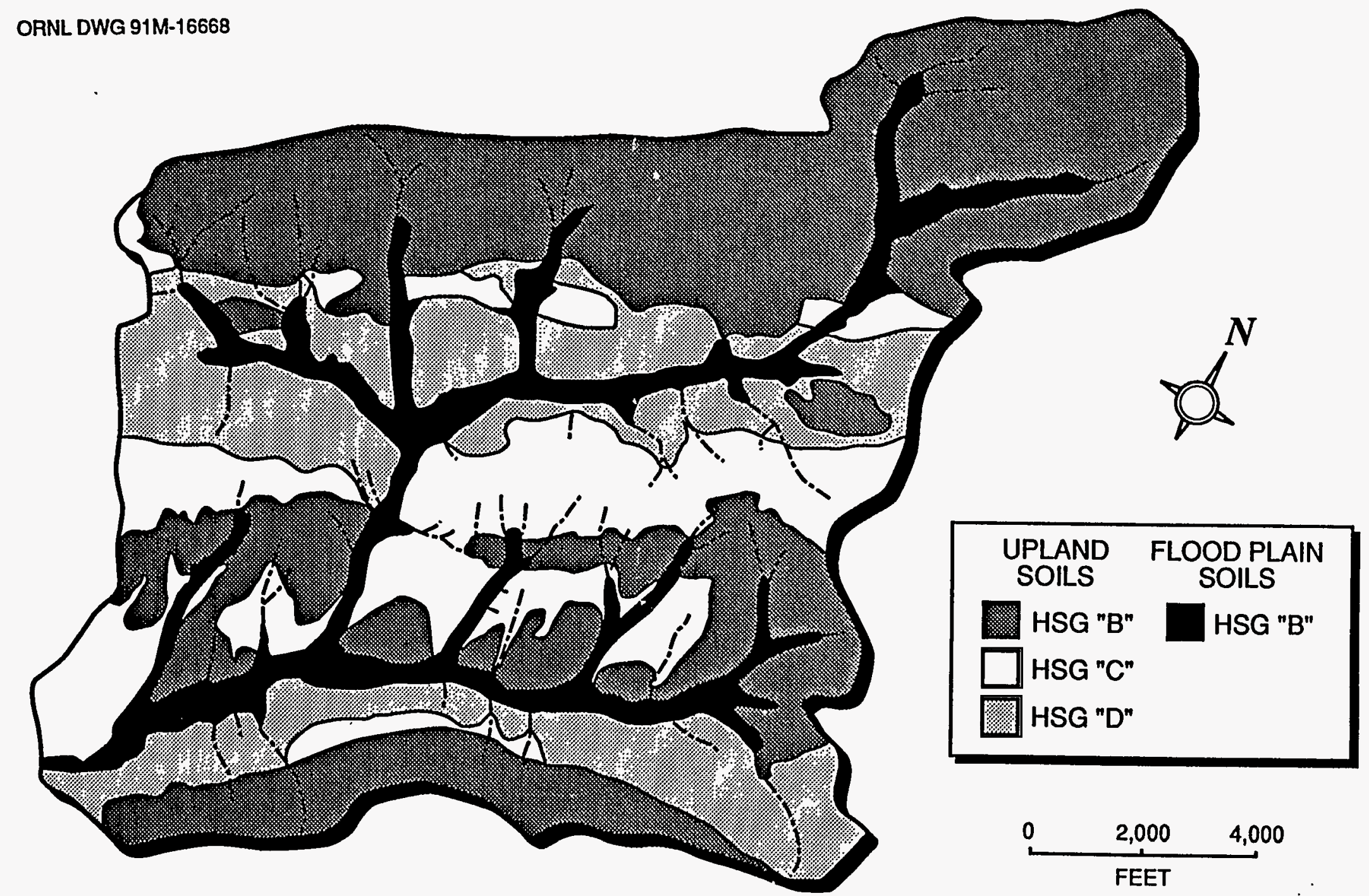

Fig. 2. White Oak Creek watershed soils classified according to hydrologic soil groups (HSGs). 
high-flow devices (i.e., weirs) for measuring discharge. The low-flow weirs were designed to accurately measure a range of flows from the minimum expected to occur at the respective site to a given flowrate considerably higher (by a factor of two or more) than wet season base flowrates. The high-flow weirs were designed to measure flows in a range from slightly less than the maximum low-flow weir discharge to maximum discharges associated with a moderate to extreme flood event of approximately 25 to 100 -year return periods.

The original stage-discharge relationships for these three monitoring stations were developed from scale model tests. In 1984-85, the low-flow control devices (sharp-crested $\mathrm{V}$-notch weirs on WOC and MB and a sharp-crested trapezoidal weir at WOD) were field rated by volumetric measurements made over a range of flows. These field ratings indicated that the original model calibrations were significantly in error. The high-flow control devices (broad-crested weirs) have never been field-rated to verify or adjust the stage-discharge relationships for determining discharge. However, standard theoretical derivations for each site indicate high-flow stage-discharge relationships significantly disagree with the original relationships still being used. For example, the maximum discharge at WOD, for a stage of $2.74 \mathrm{~m}(9 \mathrm{ft})$, calculated by the original scale model relationship and the theoretical relationship, is 2005 and $1860 \mathrm{cfs}$, respectively.

Similar conditions exist at the WOC and MB monitoring stations. However, at the MB station, much greater errors in discharge measurement occur under high-flow conditions due to submergence (drowning out) of the broad-crested weir. This happens because the channel downstream from the monitoring station is constricted. At high flows, the tailwater, unable to drain freely due to inadequate channel capacity, backs up and rises above the crest of the weir, drowning out the structure. At some critical degree of submergence (the ratio between the depth of water over the weir crest on the downstream side to the depth of water above the weir crest on the upstream side), the broad-crested weir no longer performs as designed. Above this critical degree of submergence, generally accepted to be about $0.7(70 \%)$ for rectangular broad-crested weirs, the upstream stage (head) over the weir begins to rise disproportionately to the discharge and the stage sensor detects an elevated stage for a given flow rate. Therefore, the monitoring station instrumentation calculates a higher flow rate than is actually occurring.

A theoretical rating has been developed at the MB monitoring station that uses the low-flow control with an extended rating for stages above the wall (weir sill) containing the sharp-crested weir. The method used for developing this extended rating is consistent with that used by the U.S. Geological Survey (USGS) in the past. The Environmental Sciences Division (ESD) Watershed Hydrology Group uses this extended rating to calculate flows at the MB monitoring station for flows which exceed the capacity of the low-flow weir $(34.7 \mathrm{cfs})$. Compared to the extended rating, the standard rating consistently overestimates the peak instantaneous flowrate for major storms by approximately $200 \%$.

Stage data collected during two major storm events in 1993 (March 23 and December 4) have verified that the high-flow control device (broad-crested weir) at the WOC Monitoring Station (MS3) also becomes submerged periodically due to backwater from WOL and the WOC floodplain. However, this is a transient condition occurring less frequently and for relatively short intervals. An extended rating, similar to that applied to high flows at MB 
MS4, has been developed and utilized to "correct" discharge calculations for flows occurring under submerged conditions.

Periodic submergence of the outlet structure at WOD, due to backwater from elevated stage in the Clinch River, has been identified. This condition, if unaccounted for, can cause significant errors in discharge measurement. According to Bos (1990) the high-flow control (triangular broad-crested weir) can sustain submergence of $80 \%$ without suffering a significant reduction in flow. However, above $80 \%$, the reduction due to submergence increases geometrically. A correction factor (or drowned-flow reduction factor) is applied to calculations during periods of high flow where submergence above $80 \%$ has occurred.

The high-flow measurement control devices on WOC and MB are currently being field-rated by USGS Water Resources Division staff for verification of (or adjustment to) the standard or extended stage-discharge relationships currently being used for discharge calculations at these sites. The resulting relationships will be incorporated into the data processing procedures for discharge calculations. In addition, the USGS evaluated methods for rating the high-flow control at WOD and submitted a proposal in late FY 1993. Field rating of the high-flow control at WOD, to be accomplished with discharge measurements made with an acoustic velocity meter between the sluice gates and the high-flow control (broad-crested weir), could begin as early as the summer of 1994.

The accuracy of discharge measurements at surface-water monitoring stations in the WOC watershed is being significantly degraded due to deposition of sediment and debris during high flow events resulting from heavy rainfalls. At the primary monitoring stations on WOC and $\mathrm{MB}$, the sediment and debris have essentially filled the stilling pools. At MB (MS4), sediment is now depositing on the downstream side of the station indicating that the "stilling pool" has filled to capacity and the stream has reached an equilibrium condition. That is, the approach to the sharp-crested (low-flow) weir at this station will not worsen substantially henceforth.

At least two projects have been initiated to alleviate the problems with sediment deposition at a number of sites on the WOC watershed. One project consists of removing the deposited sediments from the stilling pools at the WOC (MS3) and MB (MS4) monitoring stations. This task calls for removal of approximately 250 cubic yards of material from each site. This corresponds, approximately, to the original geometry of the approach channels as constructed in the early 1980s. This effort could be completed in the summer of 1994 . A second project is tasked with upgrading four smaller tributary monitoring stations on the WOC watershed. These upgrades will be completed separately beginning with channel dredging and instrument upgrades at the Northwest Tributary (NWT) monitoring station as early as the summer of 1994. The other three sites are the West Seep (WSP), East Seep (ESP), and Homogeneous Reactor Test (HRT) monitoring stations. Their upgrades, each to include will be completed according to a schedule not yet determined.

\subsection{FLOW FREQUENCY ANALYSES}

Whereas the emphasis for most compliance monitoring is to document and compare contaminant concentrations relative to concentration limits set forth in regulations, for the 
ERP the important information is contaminant flux, typically quantified over a period of 12 months. An appropriate measure of success for remedial actions is the reduction of this annual flux measured at key points in the hydrologic system. Measurement of the long-term contaminant flux is important because a decrease or increase in flux may lead to favorable or unfavorable assessments, respectively, of the consequences to potential health risks for individuals downstream from the Laboratory.

To generate a record of the annual flux, it is necessary to have complete and accurate flow measurements and flow-proportional water quality samples. In situations where contaminant concentrations are correlated to flow, it is possible to intensively sample stream water during storms and use these data, together with a correlation model and the annual streamflow hydrograph, to estimate annual fluxes. In all cases, reliable flow data are needed throughout the entire year.

Flow-frequency analyses are a standard method for evaluating the flow regime. These analyses indicate the magnitude and frequency of flows expected. However, the emphasis on monitoring is on measuring the total amount of contaminant discharged (product of flow rate, time, and concentration). High flows carry a disproportionate amount of contaminants for these small streams and tributaries. Therefore, it is important to measure the flow over a large fraction of the total flow volume rather than over a large fraction of the elapsed time. Volume-frequency analyses provide the necessary information to accomplish this strategy. Design flow ranges may be determined from a combination of these analyses to meet the Department of Energy (DOE) order 5400.1, General Environmental Protection Program and DOE order 5400.5, Radiation Protection of the Public and the Environment requiring the monitoring of contaminant releases in stream water on a regular schedule.

Flow-frequency and volume-frequency analyses were performed on continuous breakpoint data sets for five surface-water monitoring stations on the WOC watershed: WOC (MS3), MB (MS4), WOD (MS5), and the ESP and WSP monitoring stations. ESP and WSP each had approximately five years (1989-1993) of continuous data available for analysis, while each of the other three had four years (1990-1993) of continuous data (Figs. 3-7). Figure 7, for WSP, shows the flow-frequency curve (flow vs frequency) and the flow volume fraction curve (flow vs volume fraction) for the 5-year data set. The data show that discharge was between 0.1 and $1.0 \mathrm{cfs}$ approximately $50 \%$ of the time, with discharge seldom falling below $0.01 \mathrm{cfs}$ (< $5 \%$ of the time) and seldom exceeding $10 \mathrm{cfs}(<5 \%)$. This period of record is not enough to analyze frequency to accurately determine the discharge associated with infrequent return periods. However, the data should be fairly adequate to bracket the 95 th percentile. That is, discharge at WSP is between 0.01 and $5.0 \mathrm{cfs}$ approximately $95 \%$ of the time. However, volumetrically, $95 \%$ of the flow occurs between 0.1 and $40 \mathrm{cfs}$. This is because a disproportionately high percentage of total flow (volume) passes a point on a stream during a few major storms, whereas a small percentage of total flow (volume) passes under normal flow conditions. For example, flows of $0.1 \mathrm{cfs}$ and less occur approximately $35 \%$ of the time, yet account for less than 5\% of the total flow volume. Conversely, flows of $1.0 \mathrm{cfs}$ and greater occur less than $15 \%$ of the time, yet account for nearly $70 \%$ of the total flow volume. Likewise, flows of $10.0 \mathrm{cfs}$ and greater occur only about $1 \%$ of the time, yet account for approximately $20 \%$ of the total flow volume. This emphasizes the need to consider the discharge volumetrically because the percentage of contaminants passing a point in a stream more closely parallels flow volume. 


\section{WHITE OAK CREEK (MS3)}

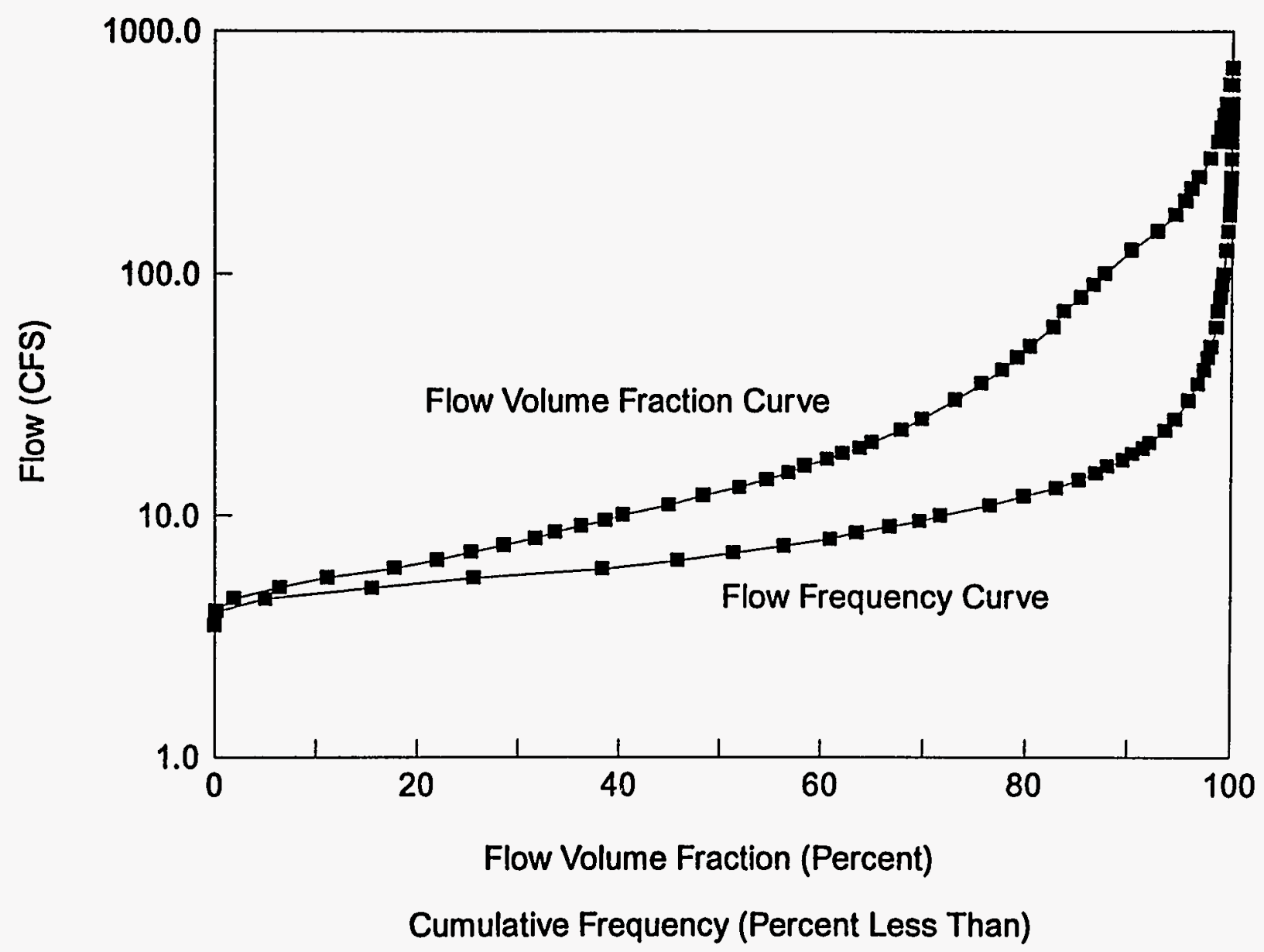

Fig. 3. Flow-frequency and flow-volume fraction curves for the White Oak Creek monitoring station (MS3), based on four years of 15-minute discharge data. 


\section{MELTON BRANCH (MS4)}

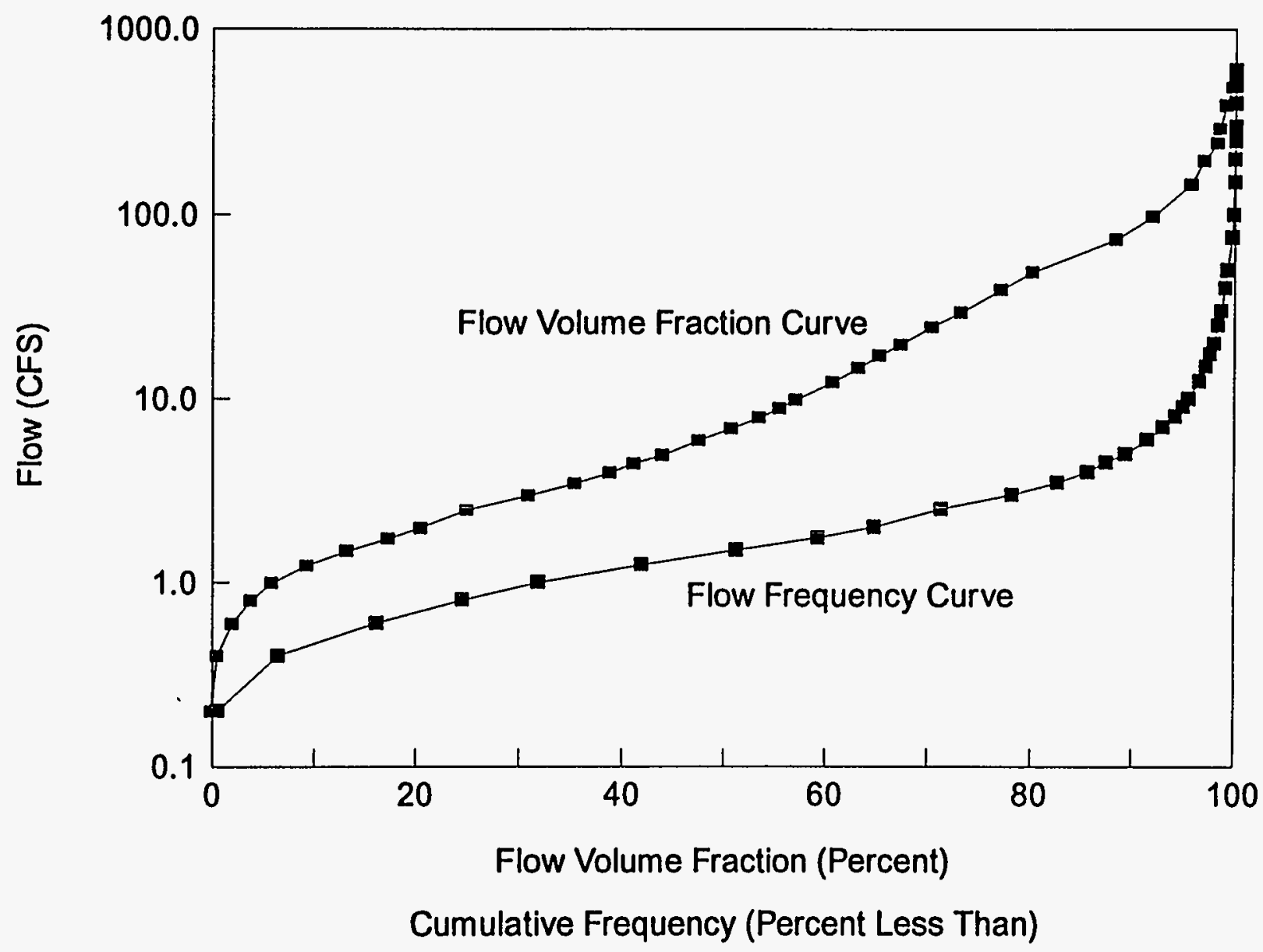

Fig. 4. Flow-frequency and flow-volume fraction curves for the Melton Branch monitoring station (MS4), based on four years of 15-minute discharge data. 


\section{WHITE OAK DAM (MS5)}

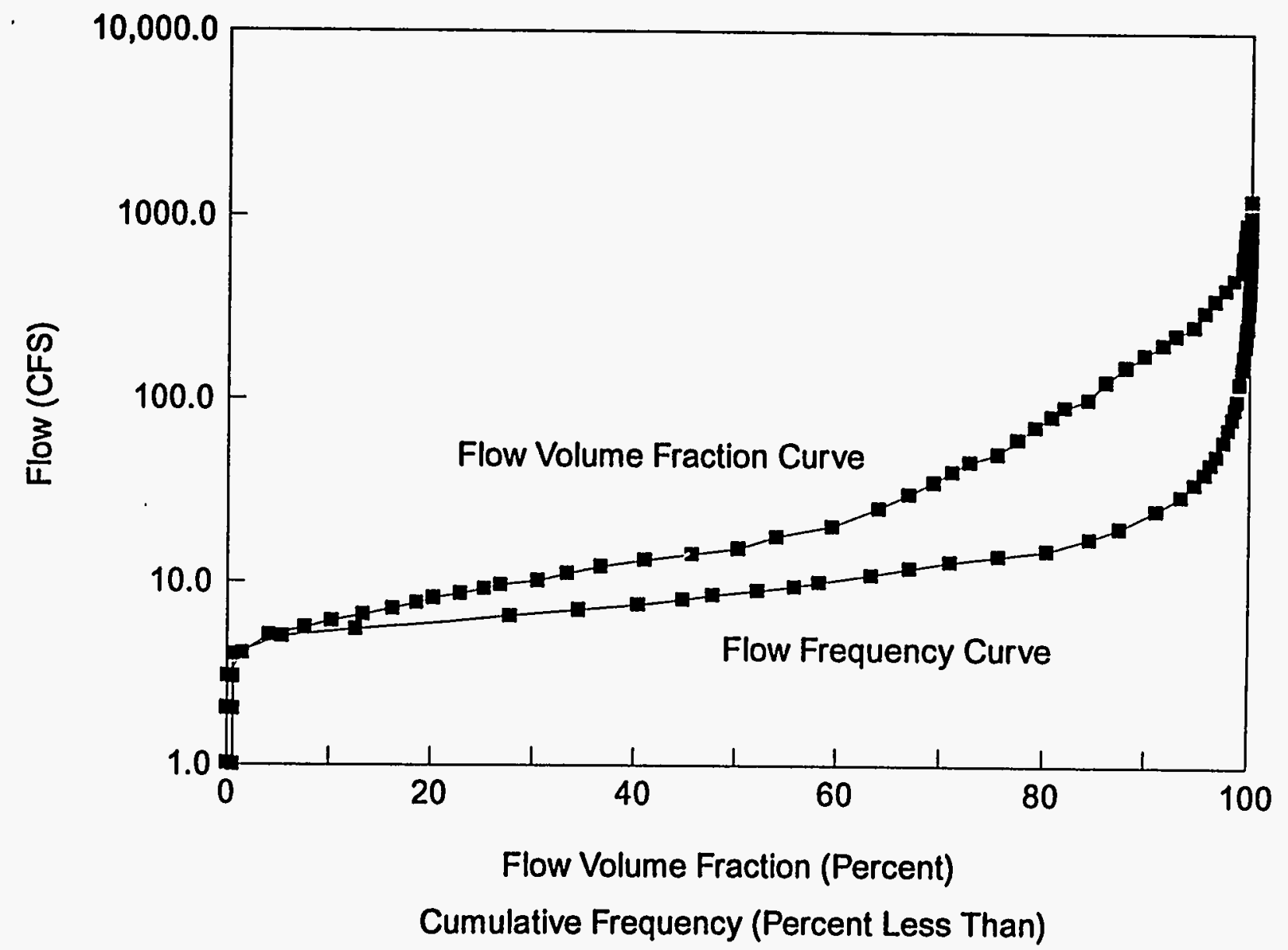

Fig. 5. Flow-frequency and flow-volume fraction curves for the White Oak Dam monitoring station (MS5), based on four years of 15-minute discharge data. 
ORNL DWG-94-10451

\section{EAST SEEP MONITORING STATION}

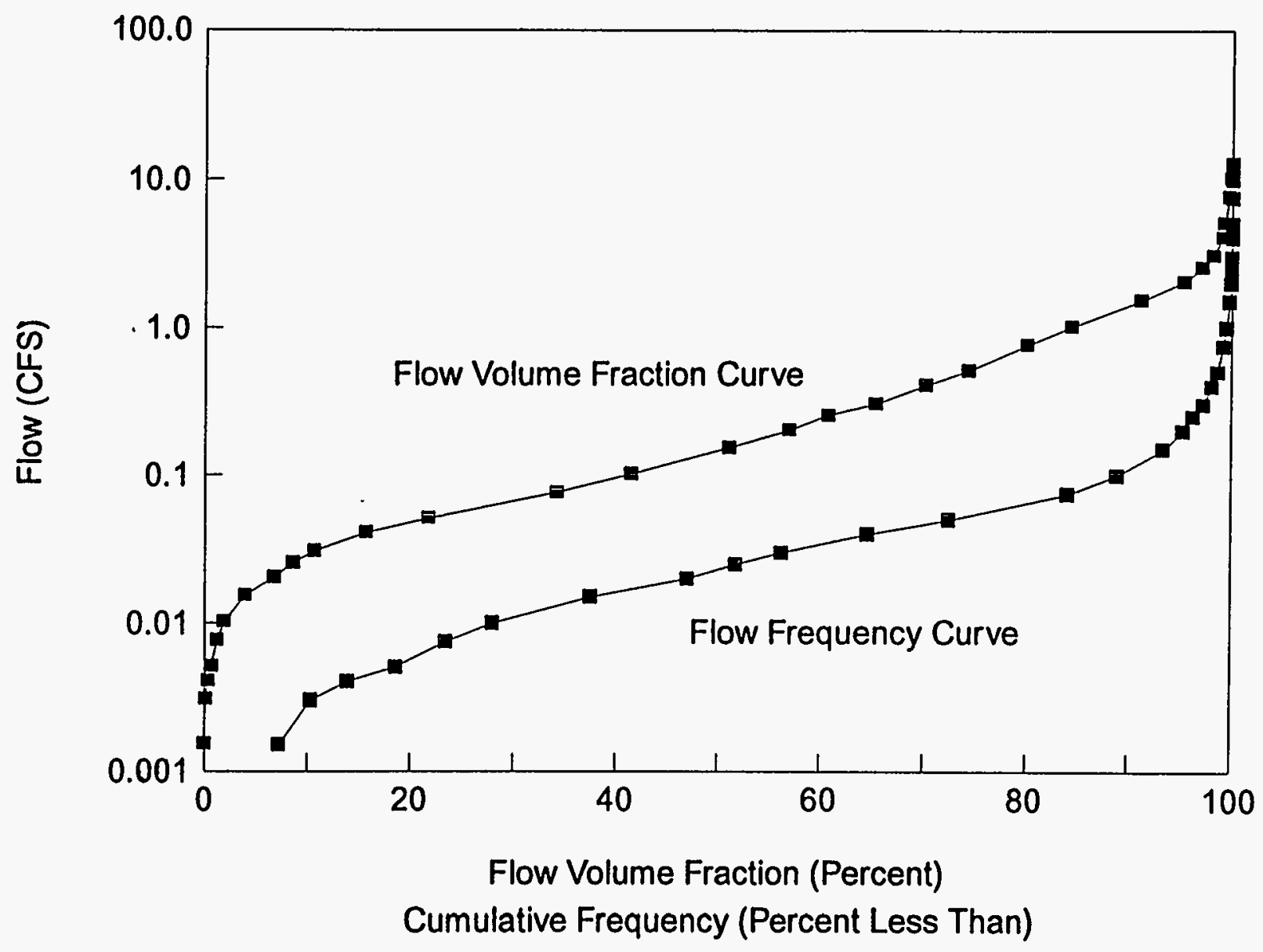

Fig. 6. Flow-frequency and flow-volume fraction curves for the East Seep monitoring station, based on five years of 15-minute discharge data. 


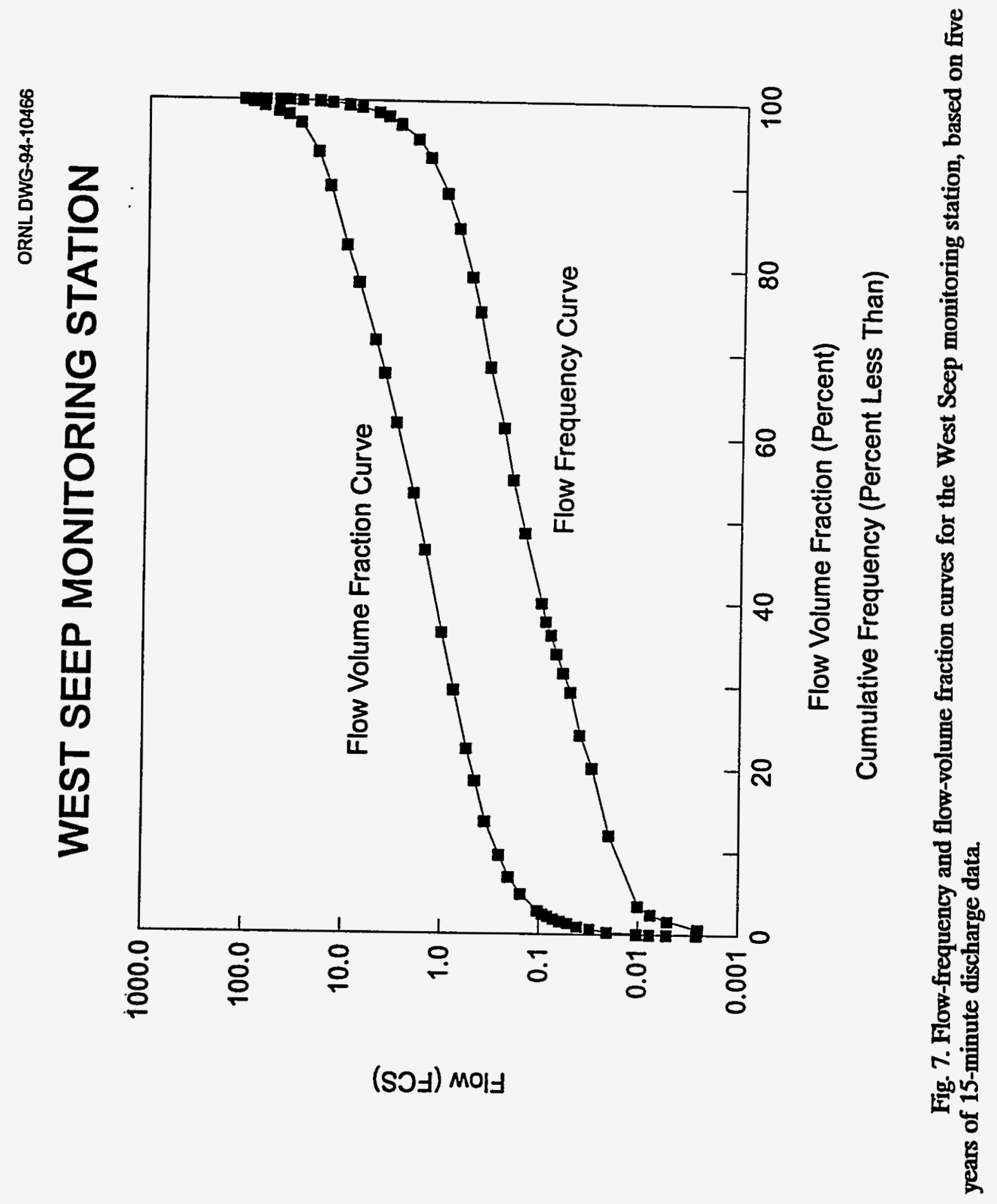





\section{HYDROLOGIC DATA}

The collection of hydrologic data in the WOC watershed began with facility planning studies in the early 1940s. Collection of these data has developed into a long-term program of environmental research studies and monitoring activities required to cope with the Laboratory's unique waste management needs.

The hydrologic data available for the report period were derived largely from ongoing studies of the ORNL ERP and, to a lesser extent, from the continuing effluent and environmental surveillance monitoring conducted by the Environmental Surveillance and Protection Section (ESPS) of the Office of Environmental Compliance and Documentation (OECD). Much of this monitoring is associated with the National Pollutant Discharge Elimination System (NPDES) permit for ORNL operations (EPA 1986). The following sections provide information on hydrologic data available in the WAG 2 and ORNL Consolidated Data Base information systems and data summaries for selected stations.

\subsection{CLIMATE}

Precipitation, temperature, humidity, wind speed and wind direction, solar radiation, relative humidity, and pan evaporation data are available for several stations located in the vicinity of the WOC watershed (Table 2). The period of record varies from station to station. The National Oceanic and Atmospheric Administration/Atmospheric Turbulence and Diffusion Division (NOAA/ATDD) monitoring station, located in Oak Ridge about $15.4 \mathrm{~km}$ ( 9.6 miles) north of the center of the watershed, is the closest long-term meteorological station, with records dating from 1947.

Precipitation is probably the most important climatic factor in hydrologic studies, since it establishes quantity and variations in runoff and streamflow. It also replenishes groundwater. Maximum, mean, and minimum annual precipitation for stations near ORNL during the period 1954-1983 were $190.0,132.6$, and $89.7 \mathrm{~cm}(74.8,52.2$, and $35.3 \mathrm{in})$, respectively (Webster and Bradley 1987). Monthly precipitation at the NOAA/ATDD station generally ranges from $13.46-15.75 \mathrm{~cm}$ (5.3-6.2 in) during the wettest months (January-March), and from 7.37-9.65 cm (2.9-3.8 in) during the driest months (August-October) (Borders et al. 1993). The normal (mean) precipitation for the NOAA/ATDD station, based on the 30-year (1963-1992) period of record, is $137.2 \mathrm{~cm}$ (54.03 in). Table 3 shows the frequency of occurrence for precipitation at various intensities over periods of 5 minutes to 24 hours (Huff and Frederick 1984). The mean annual runoff for streams in the ORNL area is $56.6 \mathrm{~cm}$ (22.3 in) (McMaster 1967). The remainder of the mean annual precipitation, about $76.2 \mathrm{~cm}$ (30 in), is consumed by evapotranspiration.

Figure 8 shows meteorological stations for which data are available and Table 4 contains site descriptions and information on data collection methodology. 
Table 2. Meteorological stations in the vicinity of the WOC watershed ${ }^{2}$ (adapted from Boegley et al. 1985)

\begin{tabular}{|c|c|c|c|}
\hline STATION DESCRIPTION & LOCATION & $\begin{array}{l}\text { PERIOD OF } \\
\text { RECORD }\end{array}$ & MEASUREMENTS \\
\hline Knoxville (TYS) ${ }^{6}$ & McGhee Tyson Airport & 1942-Present & $\begin{array}{l}\text { Precipitation, wind, temperature, temperature gradient, } \\
\text { and humidity }\end{array}$ \\
\hline Oak Ridge (ATDD) & City & $\begin{array}{l}\text { (a) } 1947-\text { Present } \\
\text { (b) } 1947-1979\end{array}$ & $\begin{array}{l}\text { (a) Precipitation, temperature, and temperature } \\
\text { gradient; (b) wind }\end{array}$ \\
\hline First Creek (1ST) & ORNL & 1987-Present & Precipitation ${ }^{\circ}$ \\
\hline USGS 7500 Bridge $(7500 \mathrm{~B})$ & 7500 Bridge & 1987-Present & Precipitation $^{e}$ \\
\hline ETF & SWSA 6 & 1980-Present & Precipitation $^{\circ}$ \\
\hline SW4 & SWSA 4 & 1986-Present & $\begin{array}{l}\text { Precipitation', temperature, wind speed and direction, } \\
\text { solar radiation, relative humidity, and pan evaporation }\end{array}$ \\
\hline ISH & Ish Creek & 1982-Present & Precipitation ${ }^{\circ}$ \\
\hline RG1 & Walker Branch & 1982-Present & Precipitation $^{\circ}$ \\
\hline RG3 & Walker Branch & 1982-Present & Precipitation ${ }^{e}$ \\
\hline BUR & Bear Creek Burial Ground & 1985-Present & Precipitation $^{\circ}$ \\
\hline $49 \mathrm{~T}$ & SWSA 6 & 1986-Present & Precipitation $^{\circ}$ \\
\hline sw7 & SWSA 7 & 1984-Present & Precipitation $^{e}$ \\
\hline
\end{tabular}

Meteorological measurements have been made at various times at the Y-12 Plant, the K-25 site, an early ORNL station, and the Tower Shielding Facility. Measurements also exist for the period 1871 until the station was moved to McGhee Tyson Airport.

Precipitation gages are not equipped to measure snowfall.

Records are discontinuous for all parameters collected at this site. 
Table 3. Rainfall vs frequency for areas up to $25.9 \mathrm{~km}^{2}(10$ miles$)$ in Anderson and Knox counties, Tennessee (adapted from Huff and Frederick 1984)

Units $=\mathbf{m m}^{2}$

\begin{tabular}{|c|c|c|c|c|c|c|c|c|c|c||}
\hline $\begin{array}{c}\text { DURATION } \\
\text { FREQUENCY } \\
\text { (years) }\end{array}$ & \multicolumn{9}{|c|}{ MINUTES $^{b}$} & \multicolumn{3}{c|}{ HOURS $^{c \mid}$} \\
\hline & 5 & 10 & 15 & 30 & 60 & 2 & 3 & 6 & 12 & 24 \\
\hline 2 & 10.9 & 16.5 & 20.3 & 29.0 & 38.1 & 45.7 & 50.8 & 61.0 & 71.1 & 83.8 \\
\hline 5 & 12.7 & 19.8 & 24.9 & 35.3 & 47.3 & 61.0 & 63.5 & 76.2 & 91.4 & 106.7 \\
\hline 10 & 14.2 & 22.6 & 28.5 & 41.9 & 55.9 & 68.6 & 73.7 & 88.9 & 104.1 & 121.9 \\
\hline 25 & 16.3 & 26.2 & 33.0 & 48.0 & 63.5 & 76.2 & 86.4 & 99.1 & 119.4 & 139.7 \\
\hline 50 & 18.0 & 29.2 & 36.8 & 53.6 & 71.1 & 86.4 & 94.0 & 119.4 & 134.6 & 154.9 \\
\hline 100 & 19.6 & 32.0 & 40.6 & 59.9 & 78.7 & 96.5 & 101.6 & 124.5 & 144.8 & 167.6 \\
\hline & & & \multicolumn{10}{|c|}{ Probable maximum, 6-h duration: 723.9} & & & \\
\hline
\end{tabular}

$11 \mathrm{~mm}=0.04$ in.

2-, 100-year and 5-, 15-, and 60-min data are from maps in NWS HYDRO-35 (Frederick et al. 1977). All other "minute" data are calculated using appropriate equations from the same publication. These equations are:

$$
\begin{array}{ll}
10 \mathrm{~min}: & (0.59)(15 \mathrm{~min})+(0.41)(5 \mathrm{~min}) \\
30 \mathrm{~min}: & (0.49)(60 \mathrm{~min})+(0.51)(15 \mathrm{~min}) \\
& \\
5 \text { year: } & (0.278)(100 \text { year })+(0.674)(2 \text { year }) \\
10 \text { year: } & (0.449)(100 \text { year })+(0.496)(2 \text { year }) \\
25 \text { year: } & (0.669)(100 \text { year })+(0.293)(2 \text { year }) \\
50 \text { year: } & (0.835)(100 \text { year })+(0.146)(2 \text { year })
\end{array}
$$

Interpolated from maps in USWB TP 40 (Hershfield 1961). 
ORNL-DWG 92M-2097R

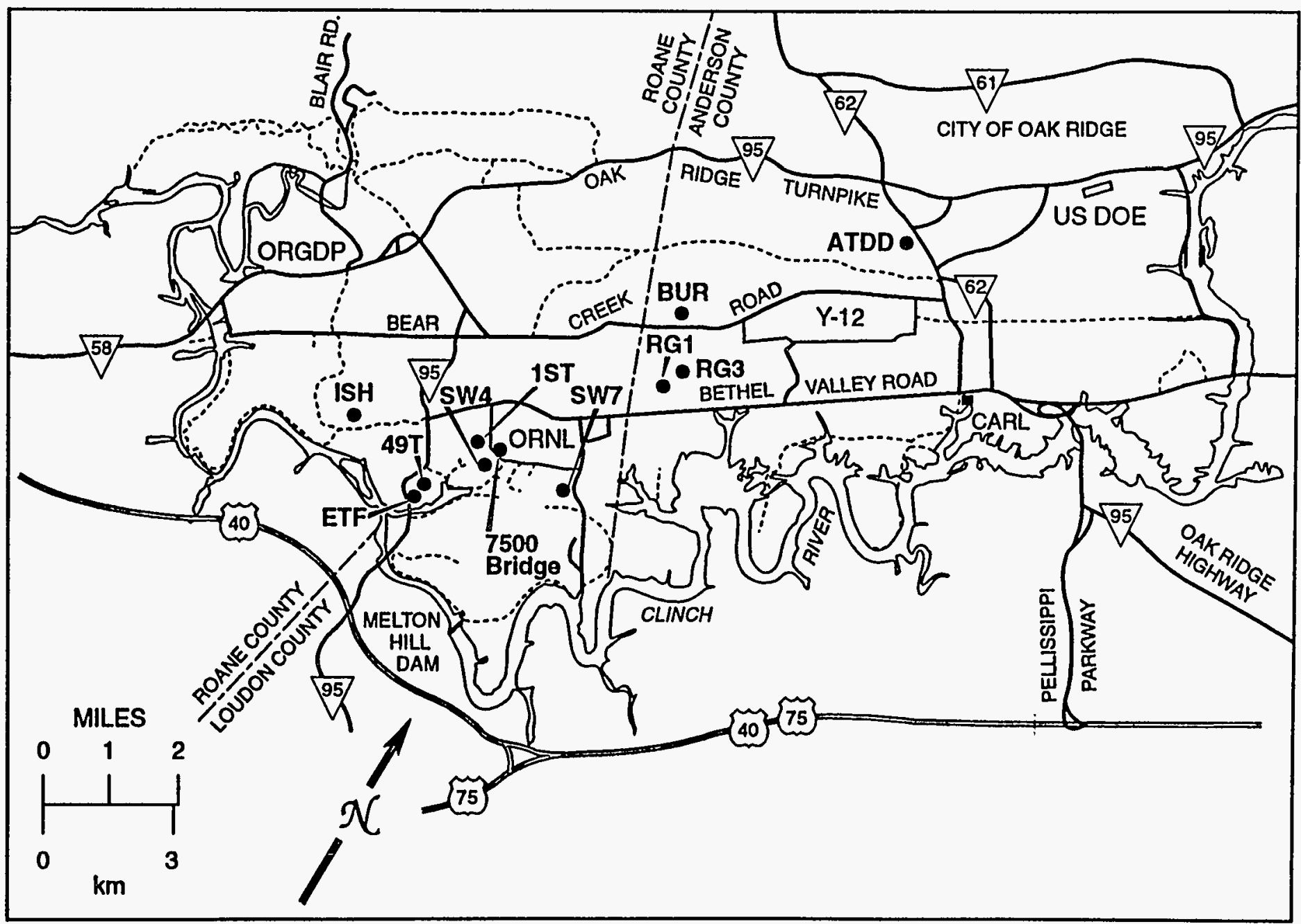

Fig. 8. Meteorological stations in the White Oak Creek watershed for which data are available through the ORNL/ERP data base systems. 
Table 4. Precipitation measurement descriptions for stations located in the WOC watershed and the NOAA/ATDD Oak Ridge station

\begin{tabular}{|l|l|l|l||}
\hline \multicolumn{1}{|c|}{ STATION DESCRIPTION } & \multicolumn{1}{|c|}{ TYPE OF GAGE } & \multicolumn{1}{c|}{$\begin{array}{c}\text { FREQUENCY OF } \\
\text { DATA COLLECTION }\end{array}$} & $\begin{array}{c}\text { SMALLEST UNIT } \\
\text { OFEASURE FOR } \\
\text { GAGE } \\
\text { (in) }\end{array}$ \\
\hline Oak Ridge (ATDD) & Belfort Weight \& Stick & Hourly & 0.01 \\
\hline First Creek (1ST) & Belfort Weighing & Hourly & 0.01 \\
\hline USGS 7500 Bridge (7500B) & Electric Tipping Bucket & 15-min & 0.01 \\
\hline ETF & Belfort Weighing & Hourly & 0.01 \\
\hline SW4 & Belfort Weighing & Hourly & 0.01 \\
\hline ISH & Belfort Weighing & Hourly & 0.01 \\
\hline RG1 & Belfort Weighing & Hourly & 0.01 \\
\hline RG3 & Belfort Weighing & Hourly & 0.01 \\
\hline BUR & Belfort Weighing & Hourly & 0.01 \\
\hline 49T & Belfort Weighing & Hourly & 0.01 \\
\hline SW7 & Belfort Weighing & Hourly & 0.01 \\
\hline
\end{tabular}


Table 5 displays monthly precipitation for the period January through December 1993 at sites in the vicinity of the WOC watershed and at the NOAA/ATDD station in Oak Ridge. Daily precipitation at these sites is shown in Appendix A.

Precipitation for the current reporting period (January through December 1993) averaged $120.7 \mathrm{~cm}$ (47.51 in) for raingages in the vicinity of the WOC watershed. Precipitation measured at the NOAA/ATDD station was $125.7 \mathrm{~cm}$ (49.01 in), $91 \%$ of normal for the 30 -year period of record. Table 6 shows precipitation at the NOAA/ATDD station was below average for 8 months and above average for 4 months of the current reporting period, resulting in a below-normal year with a deficit of approximately $12.8 \mathrm{~cm}$ (5.0 in) for the 12-month period. Figures 9 and 10 compare the annual plots (hyetographs) of daily precipitation at the First Creek (1ST) raingage in the WOC watershed with the NOAA/ATDD station in Oak Ridge for the 12-month reporting period.

Tables 6 and 7 display maximum storm event analyses for stations 1ST and the Engineering Test Facility (ETF) for the cumulative period of calendar years 1990-1993. Analyses were performed at each site to determine the maximum total rainfall recorded for durations of $1,2,3,6,12,24,48$, and 72 hours over the 4-year period. The maximum storms of short duration and high intensity, commonly associated with convective thunderstorm events, occurred during the spring (May 1990), while the maximum storms of long duration occurred in the late fall and winter months (November 1991 and December 1993). At both stations, storms of 1- to 6-hr duration occurred in May and/or December while storms of 24to 72 -hr duration occurred in late November and December.

\subsection{SURFACE WATER}

Data on surface-water discharge and quality are collected at several sites in the WOC flow system: (1) from numerous studies conducted by the ERP, (2) as part of the ESPS monitoring and compliance program associated with the NPDES permit, (3) from numerous ESD research projects, (4) from evaluations by the Interim Waste Operations group, and (5) as independent research. Some water quality data are also collected periodically as part of the Biological Monitoring and Abatement Program (BMAP), which is required by the NPDES permit (Loar 1993).

\section{Discharge}

Data on streamflow in the vicinity of the WOC watershed are collected by ESD, the USGS, and ESPS. Historic daily streamflow data have been collected at 20 sites (Fig. 11) in the WOC system are available in the OREIS consolidated data base. Three sites; WOD (MS5), WOC (MS3), and MB (MS4) are operated by ESPS as part of the NPDES permit requirements, and 6 sites are currently operated by the USGS as a component of ERP studies to isolate individual contributions from upstream hydrologic units and for application in modeling studies. An additional ESPS site (WOC Headwaters [WOCHW] monitoring station) was established on WOC, upstream of all ORNL facility effluents and Bethel Valley Road, to monitor background water quality and flow in the headwaters area. 
Table 5. Monthly precipitation totals at the WOC watershed and NOAAATDD stations for the period January-December 1993

Units $=\mathbf{c m}$

\begin{tabular}{|c|c|c|c|c|c|c|c|c|c|c|c|}
\hline DATE & 1ST & EIF & SW7 & $49 T$ & SW4 & ISH & RG1 & RG3 & BUR & $\begin{array}{l}\text { ATDD } \\
\text { Actual }\end{array}$ & $\begin{array}{l}\text { ATDD } \\
\text { Normal }\end{array}$ \\
\hline January 1993 & 9.9 & 10.5 & 9.6 & 9.8 & 9.6 & 9.9 & 8.9 & 9.0 & 10.3 & 10.1 & 8.9 \\
\hline February 1993 & 8.5 & 7.9 & 8.1 & 7.7 & 7.7 & 8.6 & 9.0 & 9.2 & 9.9 & 10.5 & 10.0 \\
\hline March 1993 & 17.6 & 17.5 & 17.2 & 16.1 & 16.5 & 19.7 & 16.1 & 16.0 & 18.0 & 16.3 & 14.4 \\
\hline April 1993 & 10.8 & 11.4 & 9.9 & 11.0 & 10.4 & 10.8 & 9.7 & 9.8 & 10.6 & 9.4 & 9.8 \\
\hline May 1993 & 8.2 & 10.4 & 7.7 & 9.5 & 9.0 & 7.9 & 7.5 & 7.6 & 9.2 & 10.9 & 8.5 \\
\hline June 1993 & 6.7 & 6.5 & 6.2 & 6.3 & 6.7 & 7.0 & 4.0 & 4.2 & 5.3 & 4.1 & 6.9 \\
\hline July 1993 & 3.5 & 3.3 & 4.5 & 3.4 & 3.7 & 3.9 & 6.4 & 6.3 & 7.4 & 5.1 & 10.3 \\
\hline August 1993 & 10.8 & 11.7 & 9.0 & 11.9 & 12.2 & 10.2 & 7.6 & 7.7 & 8.2 & 8.2 & 13.6 \\
\hline September 1993 & 11.0 & 10.9 & 9.7 & 10.7 & 11.1 & 11.4 & 12.1 & 12.4 & 14.0 & 13.0 & 13.3 \\
\hline October 1993 & 6.2 & 6.0 & 5.9 & 5.9 & 6.2 & 5.9 & 5.2 & 5.5 & 5.4 & 5.4 & 13.3 \\
\hline December 1993 & 19.0 & 20.1 & 18.8 & 18.9 & 18.9 & 20.0 & 19.9 & 19.7 & 21.3 & 21.1 & 10.7 \\
\hline CY' Total (cm) & 121.0 & 125.5 & 115.3 & 120.4 & 121.0 & 124.1 & 115.1 & 116.0 & 128.6 & 124.5 & 133.5 \\
\hline
\end{tabular}

${ }^{\prime} \mathrm{CY}$ - Calendar Year 


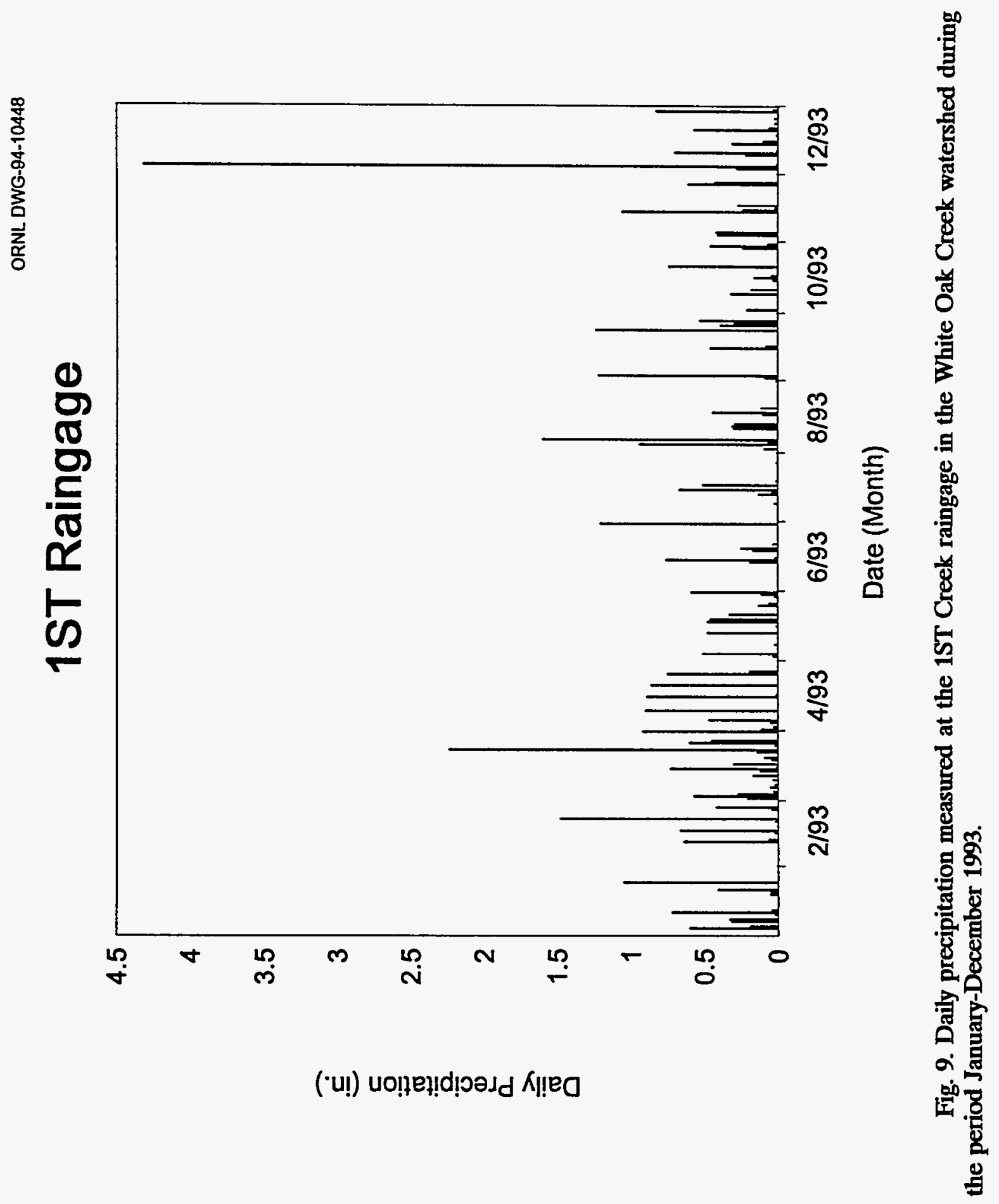




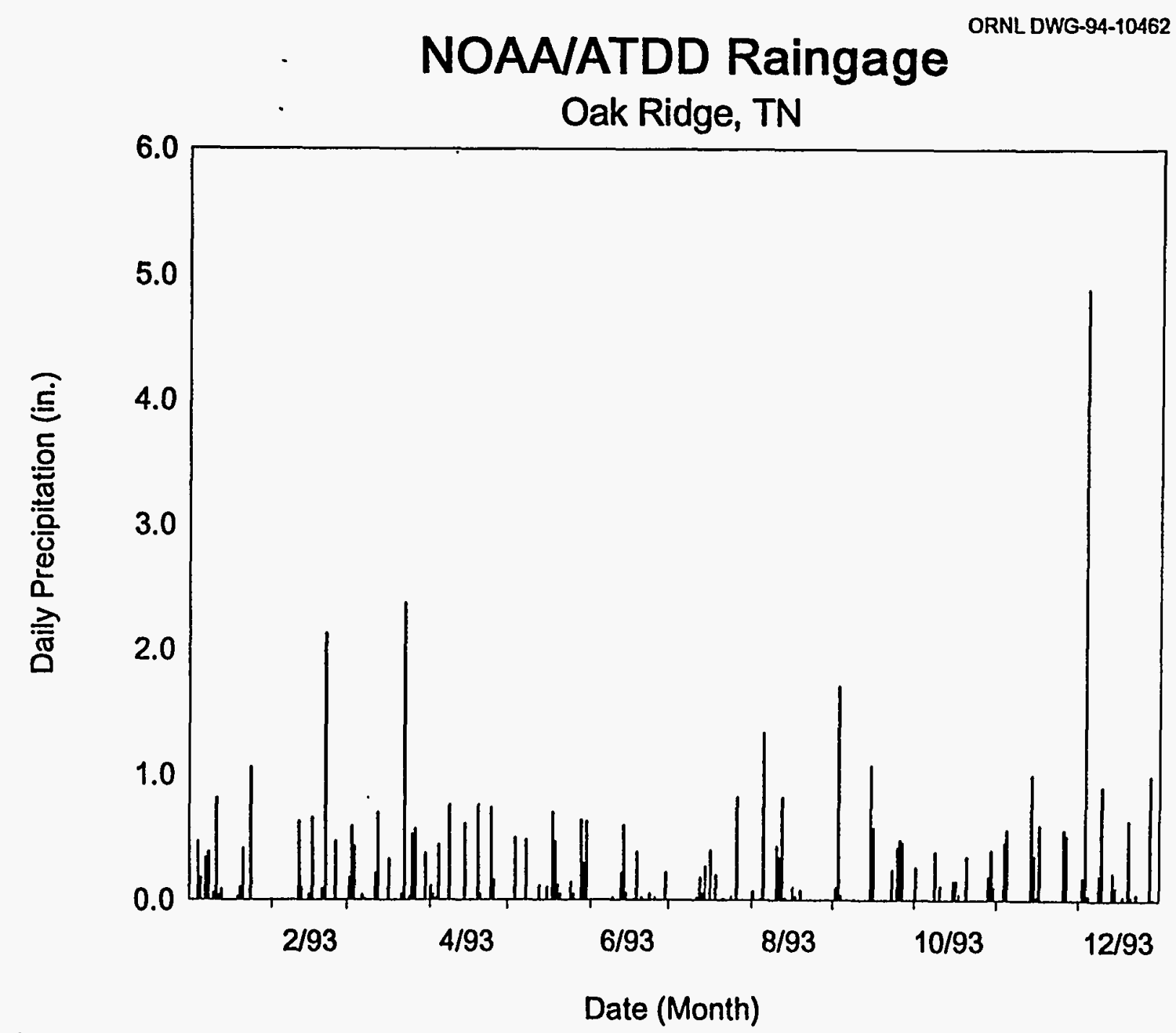

Fig. 10. Daily precipitation measured at the NOAA/ATDD raingage in Oak Ridge during the period January-December 1993. 
Table 6. Maximum storm event analysis for station 1ST

\begin{tabular}{|c|c|c|c|}
\hline \multicolumn{2}{|l|}{$\begin{array}{l}\text { RECORD BEGINS ON JANUARY 1, 1990 AT .00 HOURS } \\
\text { RECORD ENDS ON DECEMBER 31, 1993 AT 24.00 HOURS }\end{array}$} \\
\hline DURATION (hrs) & DATE & START TIME (hrs) & $\begin{array}{c}\text { RAINFALL } \\
\text { (in) }\end{array}$ \\
\hline \hline 1.00 & May 1, 1990 & 15.31 & 2.02 \\
\hline 2.00 & May 1, 1990 & 15.31 & 2.04 \\
\hline 3.00 & May 1, 1990 & 15.31 & 2.07 \\
\hline 6.00 & December 4, 1993 & 8.60 & 2.14 \\
\hline 12.00 & December 4, 1993 & 2.85 & 3.10 \\
\hline 24.00 & December 3, 1993 & 20.73 & 4.40 \\
\hline 48.00 & November 30, 1991 & 18.50 & 6.05 \\
\hline 72.00 & November 30, 1991 & 10.02 & 7.01 \\
\hline
\end{tabular}

Table 7. Maximum storm event analysis for station ETF

\begin{tabular}{|c|c|c|c|}
\hline \multicolumn{6}{|l||}{$\begin{array}{l}\text { RECORD BEGINS ON JANUARY 1,1990 AT .00 HOURS } \\
\text { RECORD ENDS ON DECEMBER 31, 1993 AT 24.00 HOURS }\end{array}$} \\
\hline DURATION (hrs) & DATE & START TIME (hrs) & $\begin{array}{c}\text { RAINFALI } \\
\text { (in) }\end{array}$ \\
\hline \hline 1.00 & May 1, 1990 & 14.55 & 1.59 \\
\hline 2.00 & May 1, 1990 & 14.55 & 2.21 \\
\hline 3.00 & May 1, 1990 & 14.55 & 2.22 \\
\hline 6.00 & May 1, 1990 & 14.55 & 2.25 \\
\hline 12.00 & December 4, 1993 & 7.37 & 3.08 \\
\hline 24.00 & December 3, 1993 & 20.80 & 4.52 \\
\hline 48.00 & November 30, 1991 & 16.83 & 6.26 \\
\hline 72.00 & November 30, 1991 & 8.23 & 7.30 \\
\hline
\end{tabular}




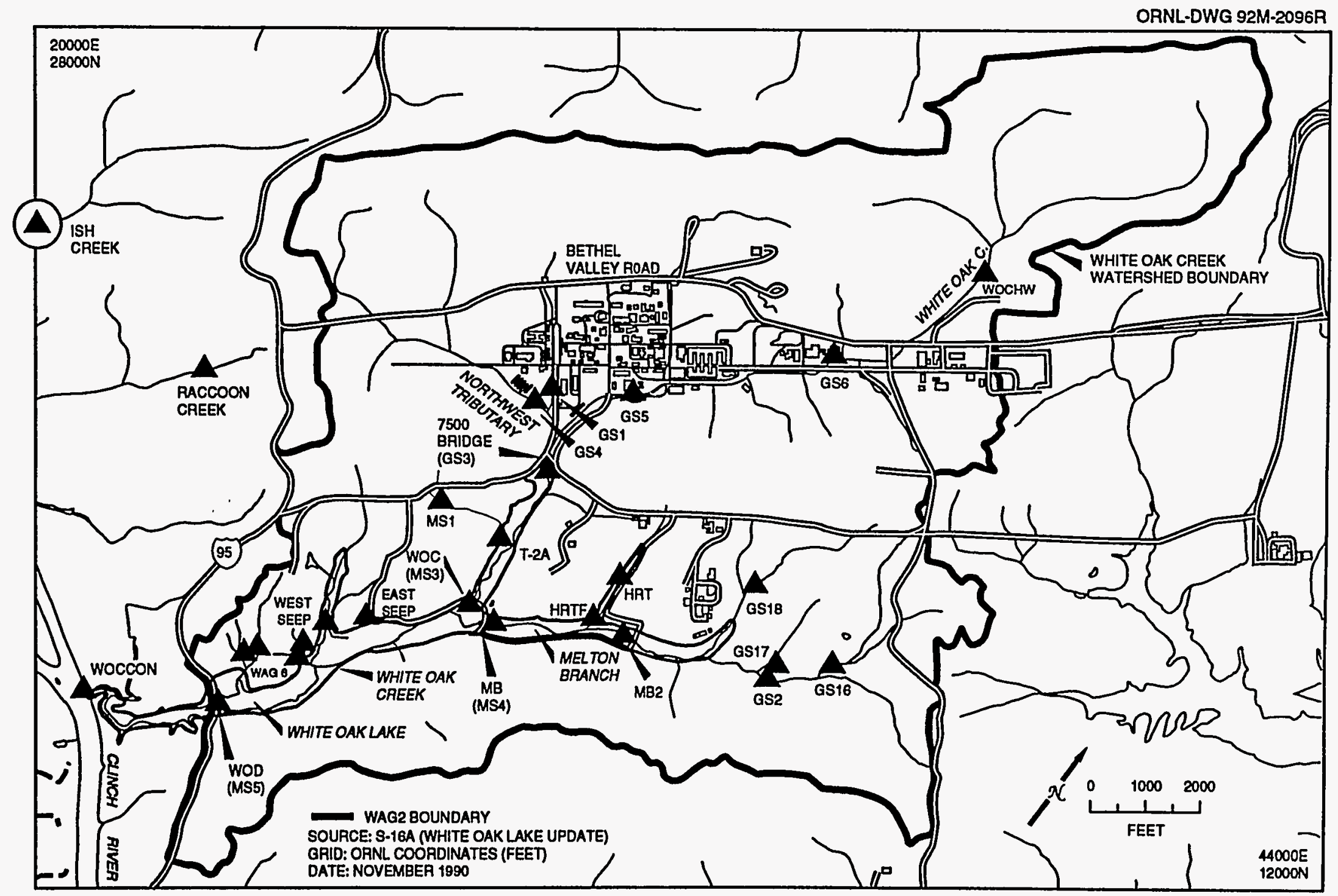

Fig. 11. Locations of surface water monitoring stations in the vicinity of the White Oak Creek Watershed. 
Stream discharge data are also currently being collected by ESD's Surface Water Hydrology Group at 12 sites. Discharge is monitored simultaneously at the four ESPS stations (above) and at eight additional surface-water monitoring stations independently. These include two sites (ESP and WSP) on tributaries that drain the pits and trenches area (WAG 7) northeast of WOL, two sites (MS1 and T2A) that drain SWSA 4 to the south into WOC, one site (HRT) that drains WAG 9 into MB above WAG 5, and three sites located outside the WOC watershed. These are Raccoon Creek, which drains a portion of WAG 3 into the Clinch River, west of State Highway 95, and the East and West forks of Walker Branch (WBE and WBW, respectively) (Fig. 12). Discharge data from both Walker Branch monitoring stations for 1993 appear in this report for the first time. Stage data have been collected at MS1, T2A, and HRT for the WAG 2 Tributary Assessment Task. These data have not been fully processed and quality assured and verified for publication. Figures 13-15 show discharge hydrographs for the three major monitoring stations on WOC (MS3), MB (MS4), and WOD (MS5) for the 12-month reporting period.

In the current reporting period, streamflow data were collected at 22 monitoring stations in and near the WOC watershed (Figs. 11-12). Ish Creek monitoring station was discontinued at the end of February 1993 due to access problems and three USGS monitoring stations in the SWSA 7 area (GS16, GS17, and GS18) were discontinued at the end of September 1993 due to funding constraints.

Physical descriptions and monitoring status information on both operating and nonoperating stations have been summarized in previous reports (Borders et al. 1993). Refer to Appendix B for revisions and/or additions to station descriptions (changes are noted in italics).

Tables 8 and 9 allow comparison of flows at selected gaging stations, monthly discharge and runoff summaries for the ten ESD sites (for which data are available from the ESD Watershed Hydrology Group) and nine USGS sites (for which data are available in the ORNL Consolidated Data Base), respectively. The total monthly volume of runoff (natural and imported) from each station was divided by its drainage area to express monthly runoff volume in inches of water. Historically, loss of water to the atmosphere is approximately 55\% of the total annual precipitation in the Oak Ridge area. The remaining $45 \%$, on the average, occurs as runoff (or discharge). At a number of stations (GS1, GS3, and GS5) in the main plant area or downstream from plant effluents, runoff volumes are greater than precipitation totals for several months of the year (see Table 9). In addition, annual runoff volume approaches annual precipitation totals at the same stations: approximately $75 \%$ at GS1, 79\% at GS3, and $67 \%$ at GS5. This highlights the magnitude and influence of imported water to monitoring stations in the WOC watershed. For comparison, two gaging stations upstream of ORNL effluents, GS2 and the WOCHW station, had runoff volumes of approximately $30 \%$ and $37 \%$, respectively. Drainage areas for each station in the flow system are listed in Tables 8 and 9, respectively. Daily flow data for these sites are listed in tables in Appendix C.

Figure 16 shows monthly mean discharge in WOC at GS3 downstream from Haw Ridge, at MS3 on WOC upstream from the confluence with MB, and the difference between monthly discharge at the two stations. Unpublished stream surveys done by the USGS in the late 1980s indicated that the average difference between GS3 and MS3 was approximately 4.5\% (Borders et al. 1993), indicating that this section of WOC is a gaining reach. Part of 


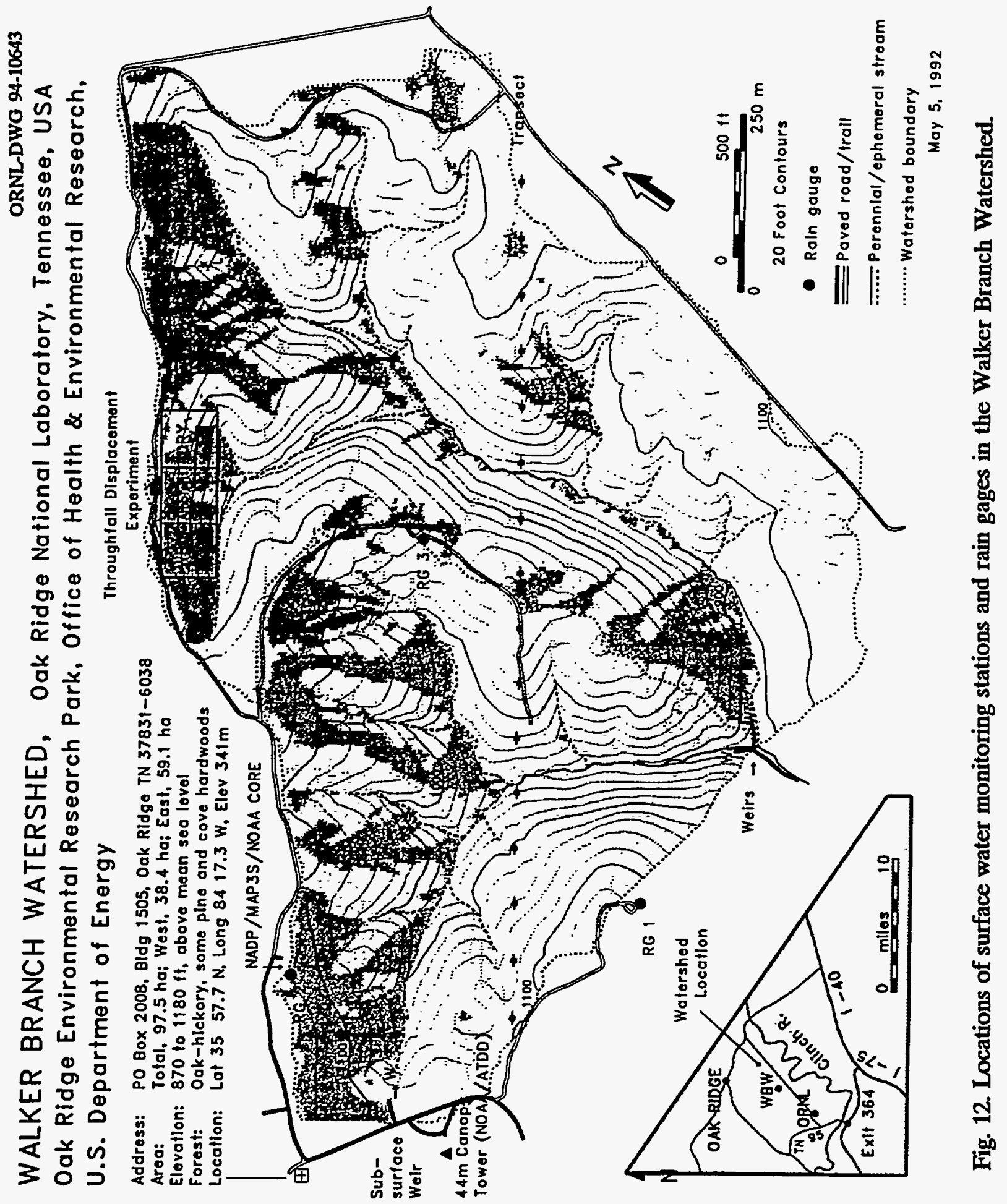




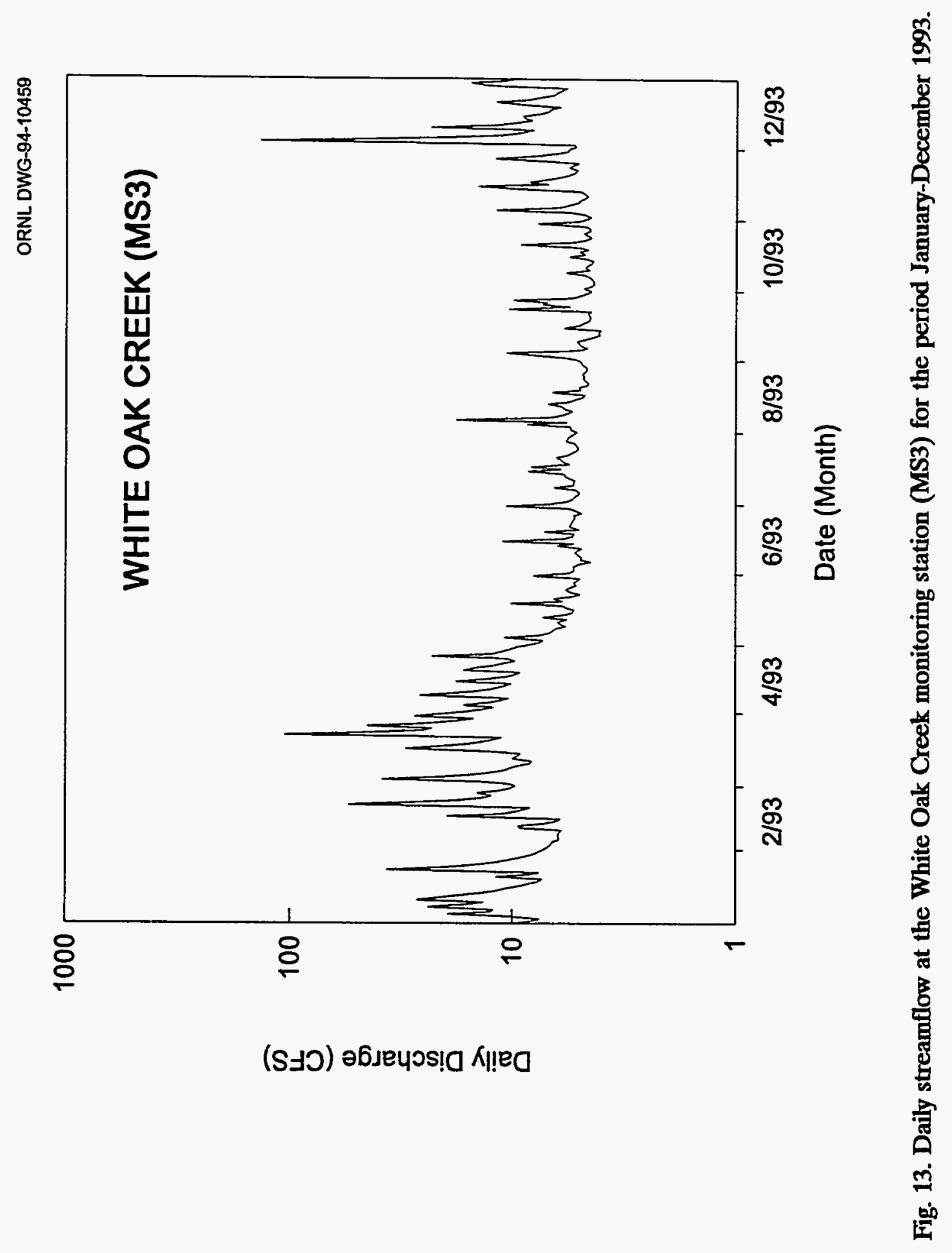




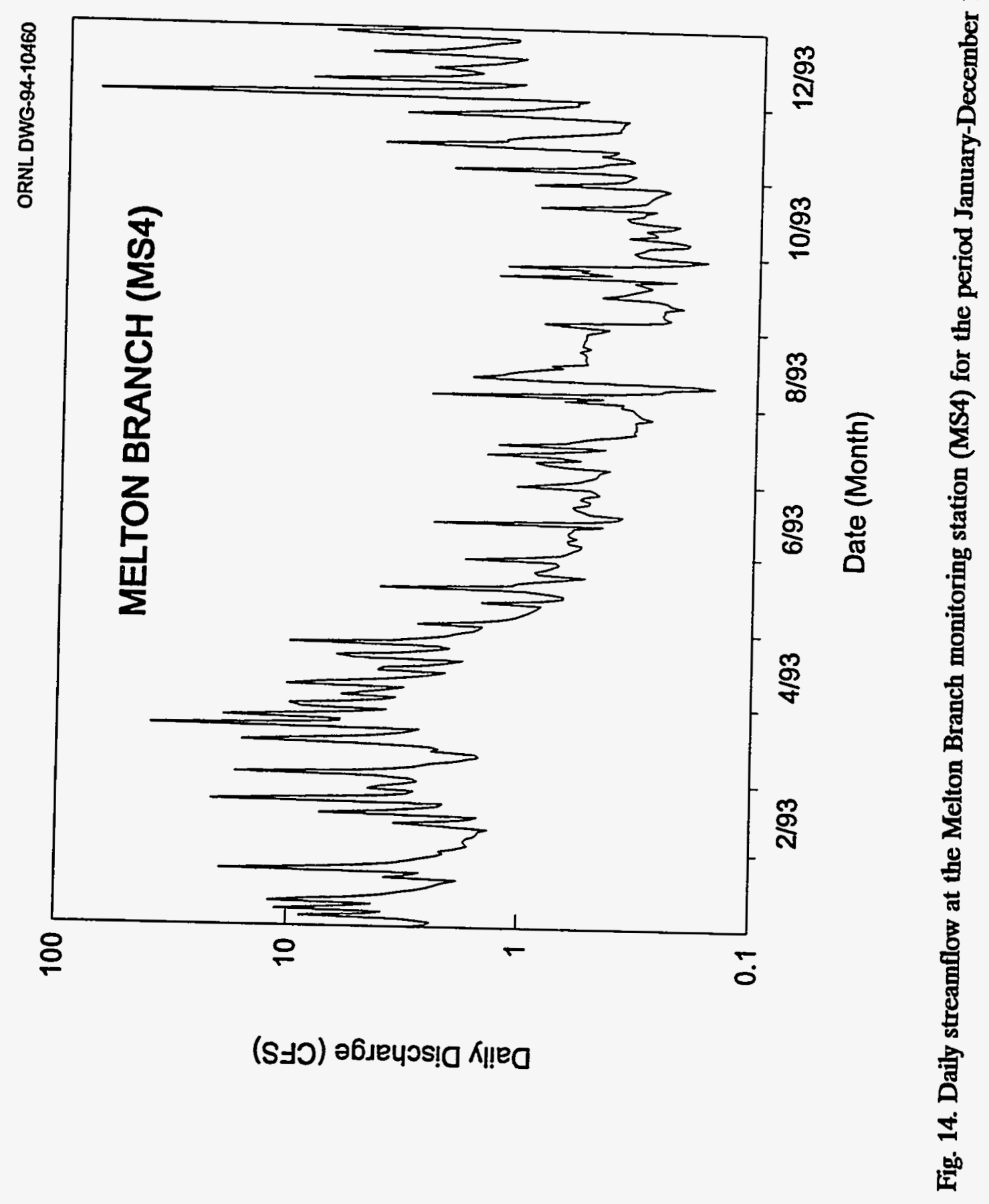




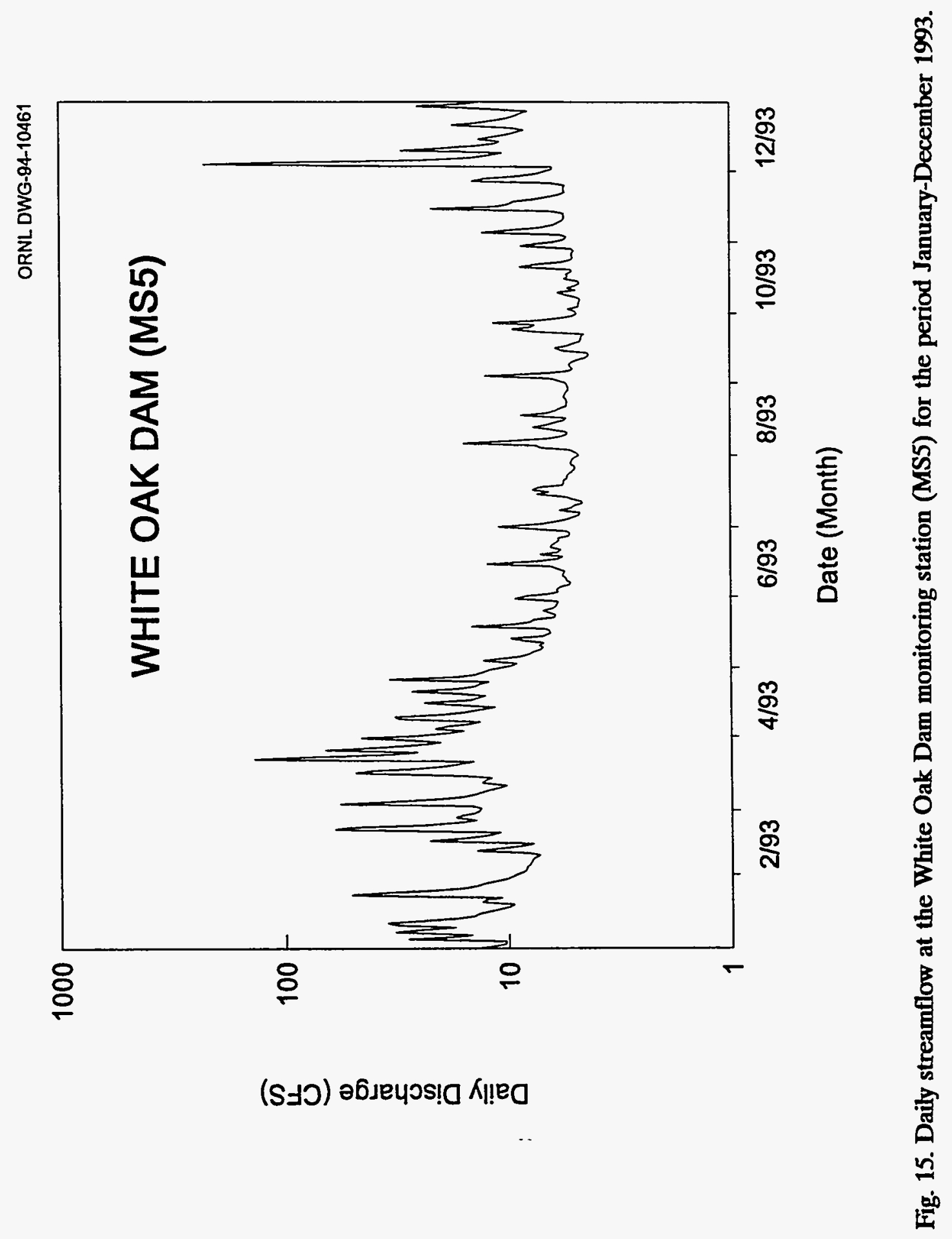


Table 8. Monthly flow and runoff statistics for ESD stations located in the vicinity of WOC watershed

Fow rate units=cfs

\begin{tabular}{|c|c|c|c|c|c|c|c|c|c|c|c|c|}
\hline & & & \multicolumn{10}{|c|}{ SIBD } \\
\hline & & & $\begin{array}{l}\text { woc } \\
\text { (Mos) }\end{array}$ & MgRo & mop & Woatw & Enesecp & Wen Soxp & $R=00000 \alpha$ & $\operatorname{mat}$ & Writur Broch & $\begin{array}{l}\text { Willorer Broud } \\
\text { Waxt }\end{array}$ \\
\hline \multicolumn{3}{|c|}{ DRAINAGE AREA (GP) } & 30 & 151 & a.15 & 200 & 20032 & 205 & 233 & 25 & 23 & ats \\
\hline 1993 & JANUARY & MEAN & 13.2 & 475 & 181 & L.86 & .074 & .65 & .48 & 208 & 0.49 & as7 \\
\hline & & MINIMUM & 7.31 & 1.76 & 9.17 & .86 & .023 & .17 & .000 & .65 & 0.13 & 0.27 \\
\hline & & MAXIMUM & 365 & 20.0 & 50.0 & 3.52 & 31 & 3.23 & 3.18 & 1.67 & 226 & $\mathbf{1 . 1 5}$ \\
\hline & & RUNOFP (n) & 4.23 & 3.62 & 340 & 2.68 & $2 B 5$ & 3.02 & 2.67 & 2.52 & 247 & 4.40 \\
\hline & FEBRUARY & MEAN & 11.6 & 3.57 & 15.0 & 1.53 & .054 & .51 & .42 & 1.60 & $a_{41}$ & 0.50 \\
\hline & & MINIMUM & 5.96 & 1.31 & 7.26 & so & .016 & .12 & .035 & .37 & 0.06 & a.n \\
\hline & & MAXIMUM & 542 & 24.8 & 59.6 & 6.89 & .30 & 3.25 & 1.54 & 6.27 & 260 & 1.98 \\
\hline & & RUNOFP (in) & 3.34 & 246 & 254 & 1.99 & 1.88 & 2.12 & 1.32 & 1.75 & 1.87 & 3.47 \\
\hline & MARCH & MEAN & 21.1 & 6.70 & 28.8 & 3.51 & .12 & 125 & 1.08 & & 0.96 & 0.93 \\
\hline & & MINIMUM & 802 & 1.50 & 10.1 & .87 & .030 & .28 & .063 & & 0.40 & 0.30 \\
\hline & & MAXIMUM & 114 & 409 & 139 & 18.0 & .69 & 9.21 & 10.5 & & 470 & 3.04 \\
\hline & & RUNOFP (in) & 674 & 5.12 & 5.40 & 5.06 & 4.45 & $5 . \pi$ & 3.79 & & 1.79 & 7.14 \\
\hline & APRIL & MEAN & 13.7 & 1.23 & 19.0 & 207 & .067 & 2.05 & .40 & & 0.57 & 0.67 \\
\hline & & MINIMUM & 9.27 & 179 & 11.4 & 1.47 & .023 & 38 & .093 & & Q40 & 0.53 \\
\hline & & MAXIMUM & 25.9 & 10.3 & 45.3 & 3.05 & .18 & 226 & L.85 & & 1.06 & 0.96 \\
\hline & & RUNOFP (in) & 4.22 & 3.12 & 3.45 & .38 & 251 & 4.67 & 1.34 & & 275 & 5.03 \\
\hline & MAY & MEAN & 644 & 2.16 & 803 & .57 & .018 & .22 & .050 & & Q.13 & a.30 \\
\hline & & MINIMUM & 4.97 & .53 & 5.93 & .33 & $<.01$ & .050 & .016 & & 0.07 & 0.23 \\
\hline & & MAXIMUM & 10.8 & 1.14 & 14.5 & 1.23 & .005 & .49 & .19 & & Q.34 & 0.46 \\
\hline & & RUNOFP (in) & 206 & 0.89 & 250 & .11 & .70 & 1.01 & .17 & & 0.66 & 2.28 \\
\hline & JUNE & MEAN & 5.71 & .65 & 7.13 & $.2 \pi$ & $<.01$ & .045 & .029 & & 0.05 & 0.21 \\
\hline & & MINIMUM & 4.45 & .37 & 5.21 & .18 & $<.01$ & .012 & $<.01$ & & 0.02 & 0.20 \\
\hline & & MAXIMUM & 11.0 & 245 & 123 & .38 & .026 & .23 & .12 & & $a_{10}$ & 0.24 \\
\hline & & RUNOFF (in) & 2.76 & 0.48 & 1.29 & .08 & .16 & .20 & .10 & & 0.25 & 257 \\
\hline
\end{tabular}


Table 8 (continued)

\begin{tabular}{|c|c|c|c|c|c|c|c|c|c|c|c|c|}
\hline & \multicolumn{10}{|c|}{ STIBD } \\
\hline & & & $\begin{array}{l}\text { WOC } \\
\text { (MSO) }\end{array}$ & $\begin{array}{l}\text { MBRR } \\
\text { (MSS) }\end{array}$ & $\begin{array}{l}\text { WOD } \\
\text { (NAS) }\end{array}$ & woarw & Bensexp & Weat Soop & $R=00000$ Cx. & $\omega \alpha_{0}^{1}$ & 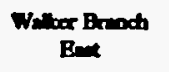 & $\begin{array}{l}\text { Woltor Brench } \\
\text { Wore }\end{array}$ \\
\hline & JULY & MEAN & s.m & .56 & 2.24 & .15 & $<.01$ & .015 & $.010(e)^{2}$ & & 0.03 & 0.18 \\
\hline & & MINIMUM & 5.06 & .28 & 4.95 & .094 & 0 & 0 & $<.01$ & & $<0.01$ & 0.17 \\
\hline & & MAXIMUM & 8.48 & 1.46 & 13.0 & .23 & .012 & .094 & .053 & & 0.05 & 0.21 \\
\hline & & RUNOFP (in) & 1.84 & .43 & 2.19 & .2 & .06 & .07 & $.04(e)$ & & 0.14 & 1.40 \\
\hline & AUGUST & MEAN & 5.82 & .67 & 633 & $.14(6)$ & $<.01$ & $.042(e)$ & $.017(e)$ & & 0.01 & 0.17 \\
\hline & & MINIMUM & 4.59 & .15 & 475 & .061 & 0 & 0 & $<.01$ & & 0.00 & 0.15 \\
\hline & & MAXIMUM & 17.8 & 2.56 & 15.6 & .41 & .049 & .40 & .07 & & 0.09 & 0.26 \\
\hline & & RUNOFF (in) & 1.86 & .51 & 1.19 & $.20(0)$ & .16 & $.19(c)$ & $.06(c)$ & & 0.03 & 1.32 \\
\hline & SEPTEMBER & MEAN & 5.64 & .12 & 609 & .14 & $<.01$ & $.044(c)$ & .020 & & 0.01 & 0.16 \\
\hline & & MINIMUM & 100 & .17 & 130 & $.0 n$ & 0 & $<.01$ & $<.01$ & & 0.00 & Q.15 \\
\hline & & MAXIMUM & 10.6 & 1.34 & 12.5 & .32 & .030 & .25 & .16 & & 0.09 & 0.18 \\
\hline & & RUNOFF (in) & 1.74 & .31 & 1.11 & .19 & .10 & $.19(0)$ & .07 & & 0.05 & 1.16 \\
\hline & OCTOBER & MEAN & 197 & .34 & 5.46 & $.11(0)$ & $<.01$ & .038 & .016 & & 0.01 & 0.16 \\
\hline & & MINIMUM & 4.32 & .20 & 4.69 & .068 &.$\infty$ & .012 & $<.01$ & & 0.00 & 0.15 \\
\hline & & MAXIMUM & 9.22 & .6 & 8.65 & .19 & .014 & .16 & .075 & & Q.04 & 0.19 \\
\hline & & RUNOFF (in) & 1.59 & .26 & 1.02 & $.16(0)$ & .07 & .18 &.$\infty$ & & 0.03 & 220 \\
\hline & NOVEMBER & MEAN & 6.54 & .93 & 7.84 & .20 & .012 & .14 & .092 & & 0.04 & 0.18 \\
\hline & & MINIMUM & 4.49 & .35 & 5.37 & .099 & $<.01$ & .021 & $<.01$ & & 0,00 & 0.13 \\
\hline & & MAXIMUM & 14.3 & 4.29 & 21.7 & 57 & .000 & .82 & .84 & & 0.15 & 0.25 \\
\hline & & RUNOFF (in) & 202 & .69 & 1.42 & .28 & .42 & .61 & .31 & & 0.17 & 2.36 \\
\hline & DECEMBER & MEAN & 15.4 & 5.16 & 2ns & $1.86(0)$ & .063 & .97 & .91 & & a.39 & 0.42 \\
\hline & & MINIMUM & 5.25 & .58 & 624 & .16 & $<.01$ & .065 & .02 & & 0.01 & Q.15 \\
\hline & & MAXIMUM & 158 & 73.1 & 266 & 188 & 236 & 160 & 16.7 & & 120 & 266 \\
\hline & & RUNOFF (in) & 199 & 3.94 & 1.2 & $268(e)$ & 296 & 149 & 3.17 & & 194 & 3.25 \\
\hline $\begin{array}{l}\text { wo } \\
\text { wo } \\
\text { Mo } \\
\text { wol }\end{array}$ & $\begin{array}{l}\text { Vhilcoast Creet } \\
\text { =ouk Creet (M) } \\
\text { o Branch (MS } \\
\text { eoak Dam (MS }\end{array}$ & adwatera. & & & & & & & & & & \\
\hline
\end{tabular}

${ }^{1}$ Ish Creek monitoring station was not accessible after February, 1993.

${ }^{2}(\mathrm{e})$ - Estimated data. 
Table 9. Monthly flow and runoff statistics for USGS stations located in the vicinity of WOC watershed

Flow rate units $=\mathrm{cfs}$

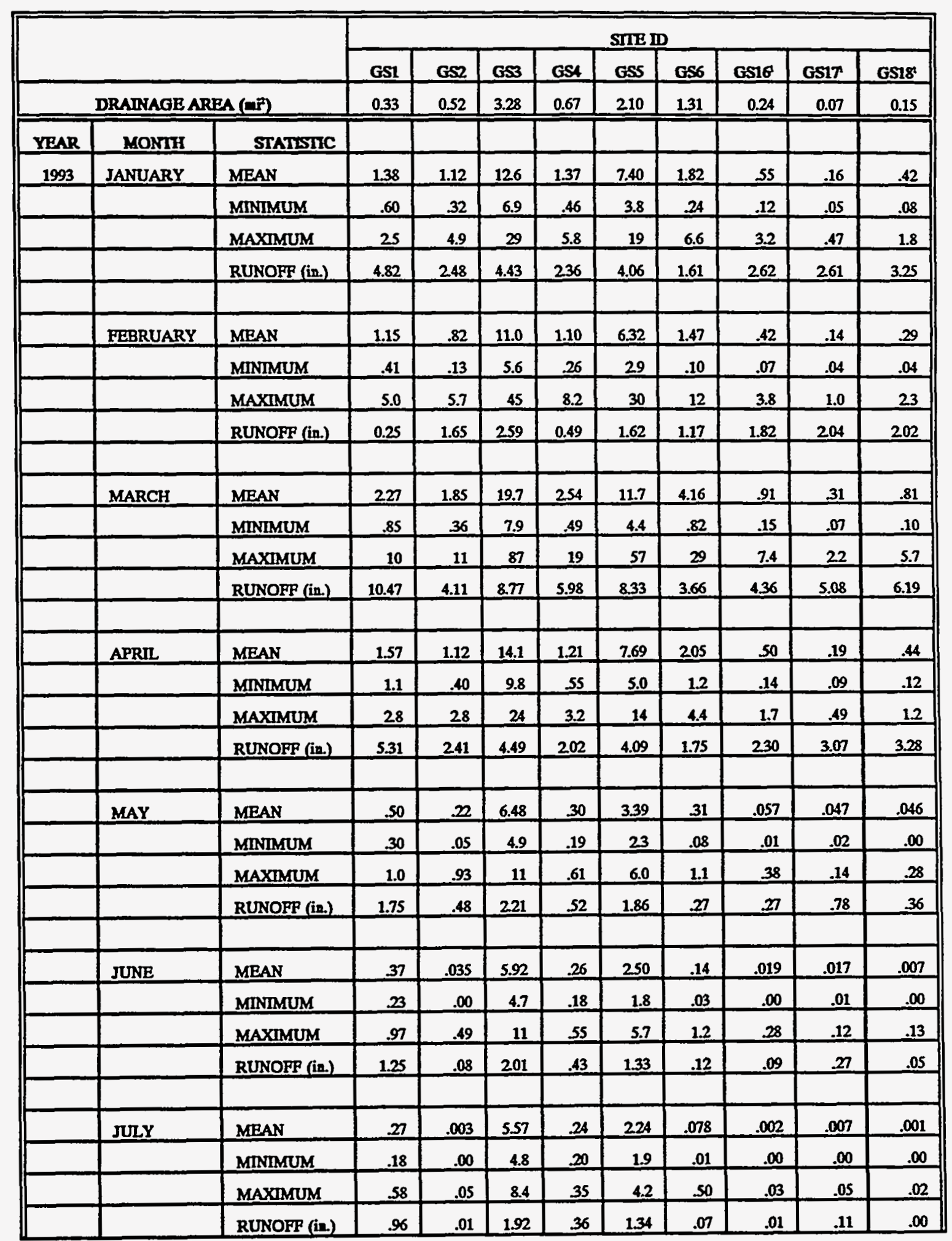


Table 9 (continued)

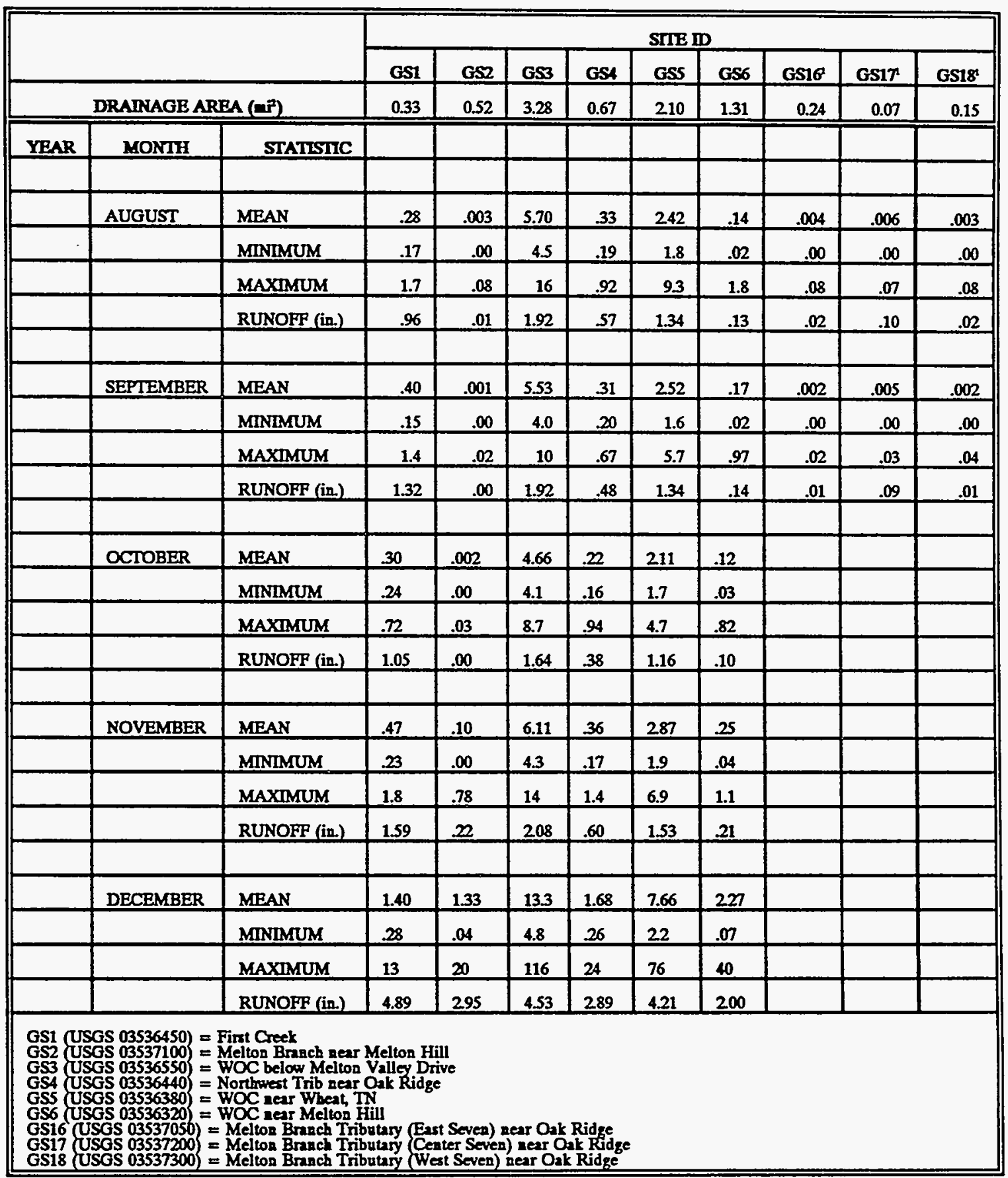

'GS16, GS17, and GS18 were discontinued on September 30, 1993. 


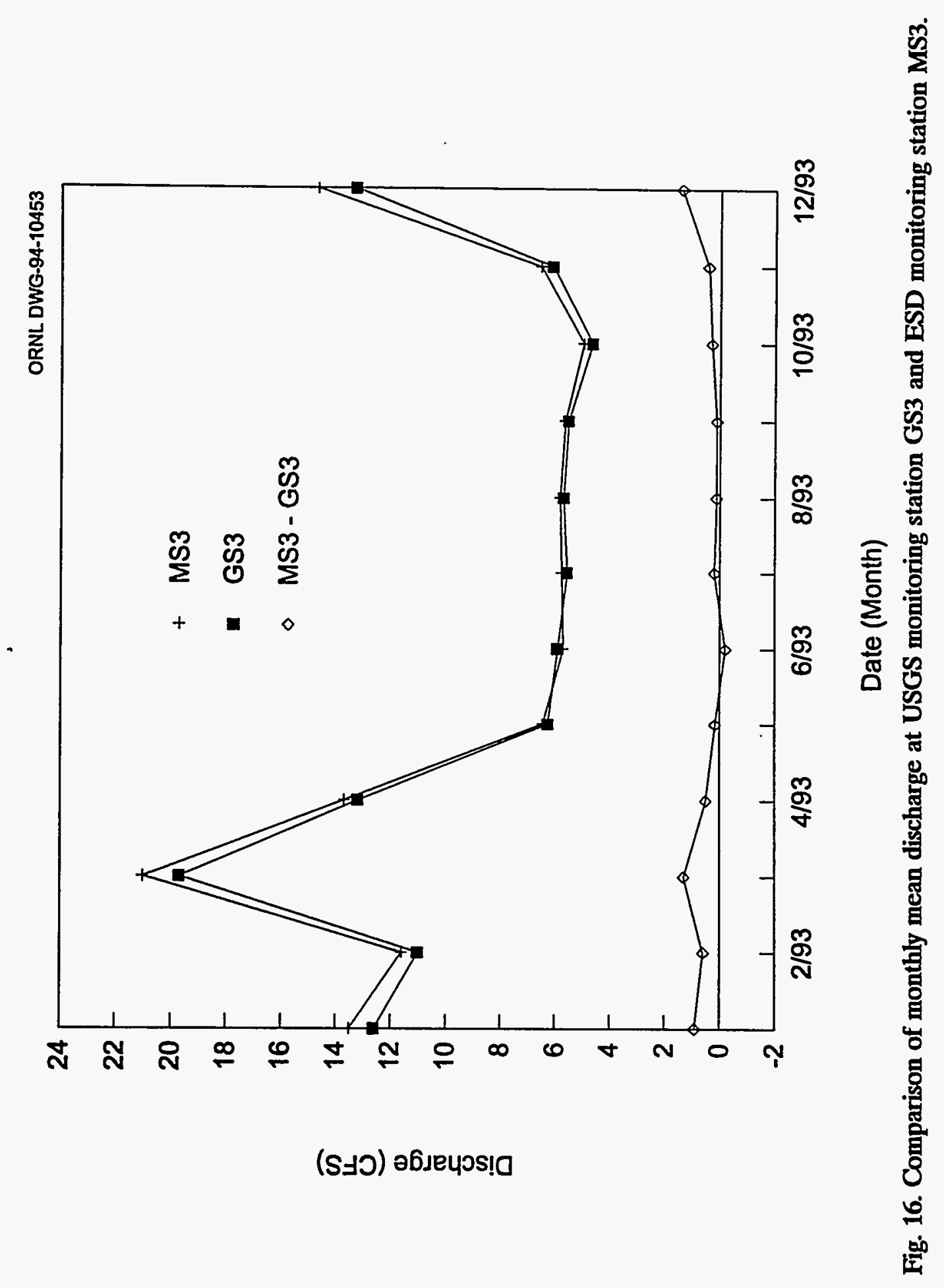


this difference can be attributed to the contribution from the small tributary draining the southern boundary of WAG 4. Differences in monthly discharge for the current reporting period were negative for only one month (June 1993). The difference in discharge for the 12-month period was approximately $5.7 \%$. This is slightly higher than previously reported but less than the relative difference in drainage area $(10 \%)$ between the two sites. Differences may be expected to approach this value in wet years as runoff from the contributing area between the stations becomes more significant relative to the nearly constant process water inputs.

Figure 17 shows monthly mean discharge at MS3 on WOC, MS4 on MB above the confluence with WOC, MS5 at WOD, and the differences between the flow at MS5 and the sum of flows at MS3 and MS4. The occurrence of negative flows, despite an appreciable contributing drainage area $\left(1.04 \mathrm{mi}^{2}\right)$, highlights the need for field rating and verification of the high-flow, stage-discharge relationships at each of the three gaging stations (see Section 1.5). However, all the negative differences occurred in months (January, February, and June-August) with below-average precipitation, or in the summer when evapotranspiration rates are higher and soil moisture deficits tend to be high, resulting in less runoff. Local inflows from ungaged areas around the lake are also negligible at these times. In addition, sections of lower WOC above the headwaters of WOL may be losing reaches, and WOL presents a significant surface area for losses due to evaporation during hot, dry periods. Therefore, a significant portion of the negative differences may be accountable. Nevertheless, the causes of these negative differences should be verified or corrected.

Figure 18 shows monthly mean discharge at the WOCHW station north of Bethel Valley Road, at the foot of Chestnut Ridge, at GS6 downstream on WOC, south of Bethel Valley Road, and the difference between GS6 and WOCHW. Typically, during periods of high flow (wet season), discharge at GS6 is greater than at WOCHW, which is to be expected due to the increase in drainage area at GS6. However, during periods of low flow (dry season), WOCHW discharge has typically (historically) been greater than at GS6. During the two wettest months of 1993 (March and December) discharge at GS6 was greater than at WOCHW. For every other month in 1993, discharge ranged from nearly the same at the two stations to significantly greater at WOCHW.

The stream reach between these two stations is a losing reach. The Knox Group, which underlies Chestnut Ridge, is the major water-bearing formation in the watershed (see Section 1.3). The Chickamauga Group underlies Bethel Valley. The Benbolt formation of the Chickamauga Group lies directly under the losing reach between GS6 and WOCHW (Borders et al. 1991). This formation is made up of limestone layers which bisect WOC and in which pronounced solution channels have formed. Flow is along the strike of these limestone layers. The WOCHW flows from the southern slopes of Chestnut Ridge, bisects the shallow limestone layers of the Benbolt formation, and is partially intercepted.

It appears that the flow, originating as surface flow at WOCHW and ultimately being lost to the subsurface in the Benbolt formation before reaching GS6 through WOC, is reappearing as surface flow in the duck pond at Bethel Valley Road near the main portal to ORNL. The fact that the difference between the duck pond outflow and inflow is greater than that portion of flow lost from WOC is typical of the geohydrologic regime. Presumably, 


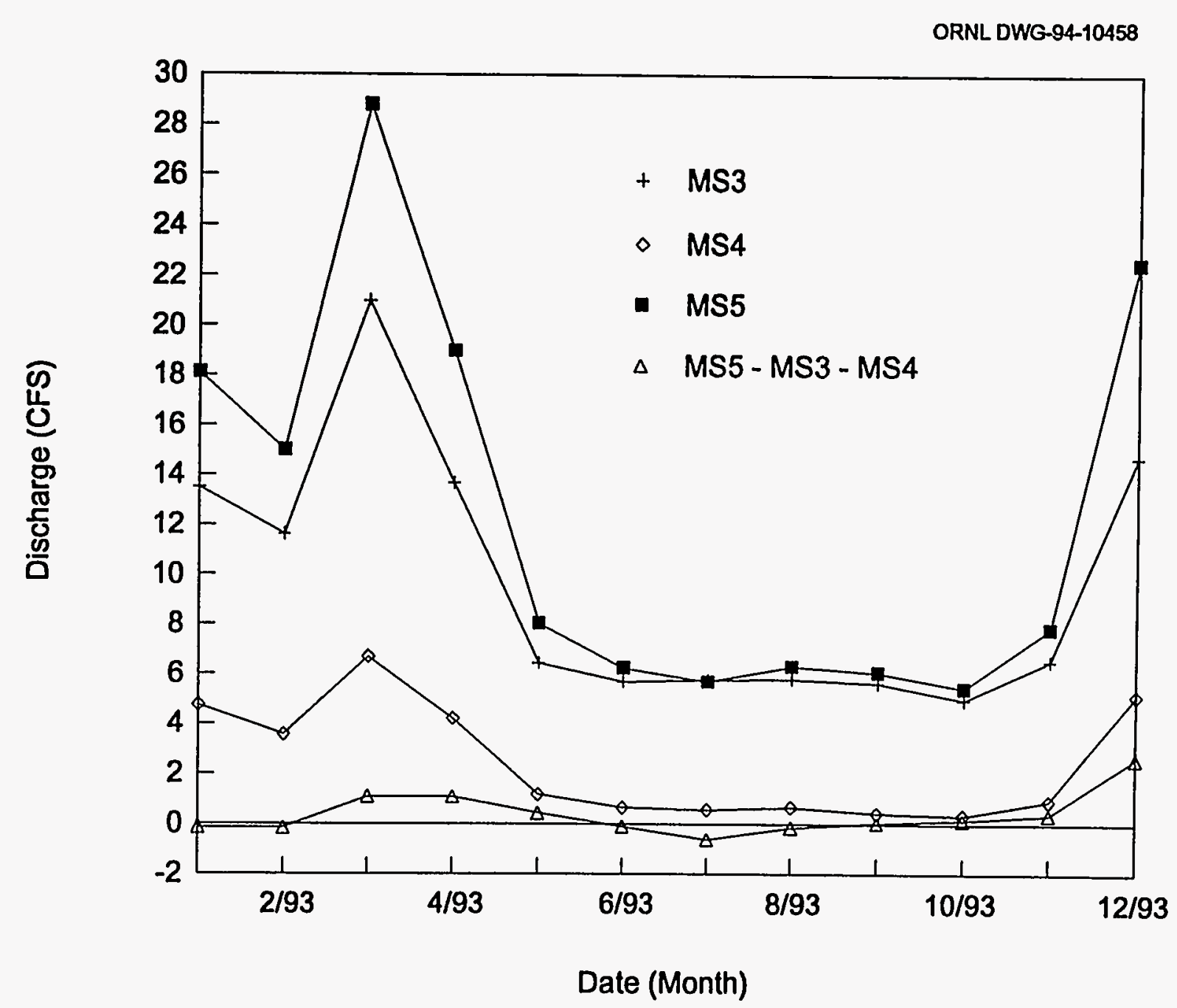

Fig. 17. Comparison of monthly mean discharge at ESD monitoring stations MS3, MS4, and MS5. 


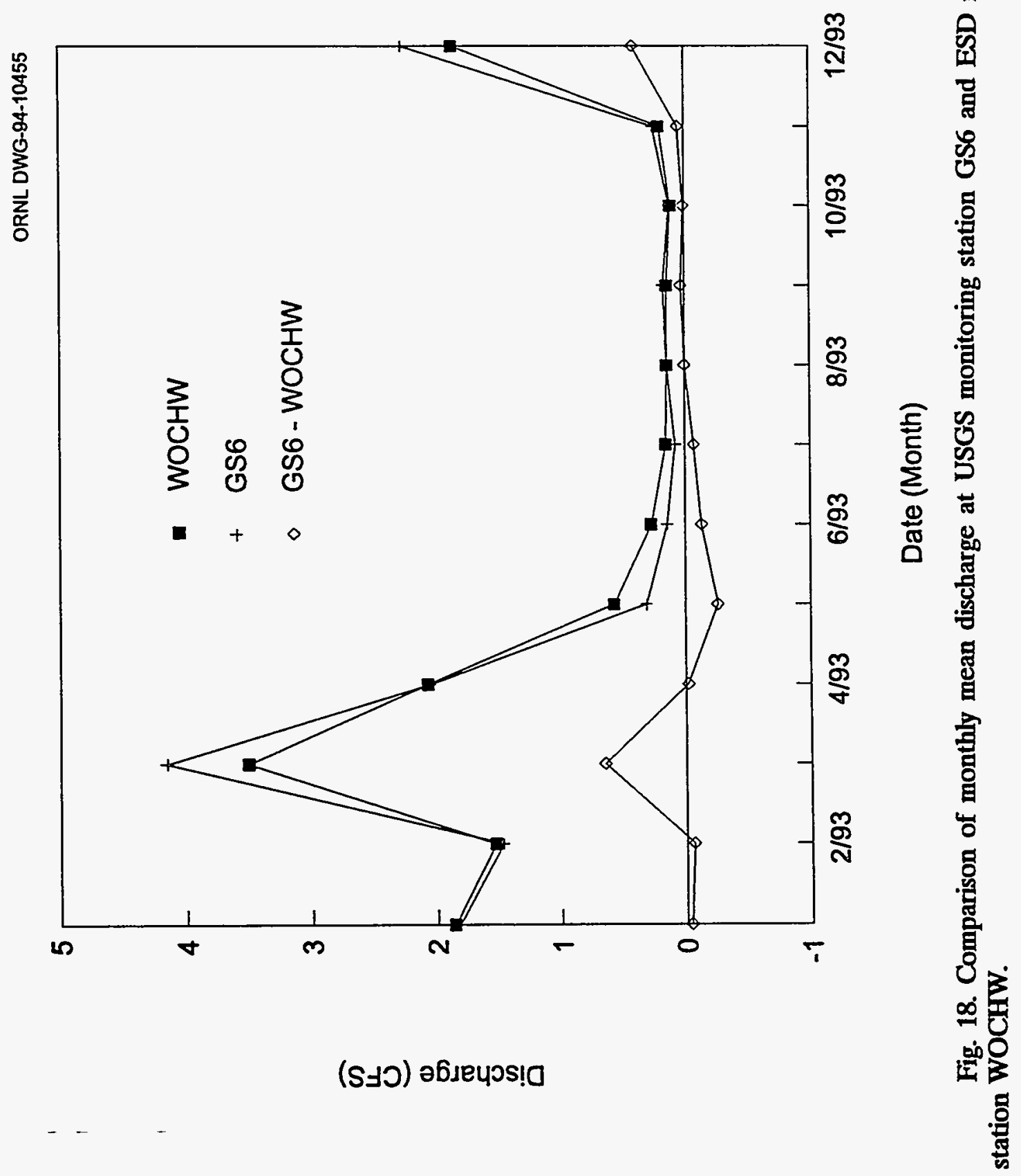


additional water is being supplied to the duck pond from the Knox formation underlying Chestnut Ridge.

Rating tables for most of these monitoring stations are available in previous reports (Borders et al. 1991, Borders et al. 1992, and Borders et al. 1993). In this report, only those rating tables that are known to have changed have been included with the rating table for the East and West Forks of Walker Branch as an addition (Appendix D). Table 10 summarizes the status of the ratings for weirs in the vicinity of the White Oak Creek watershed.

\section{2 .2 Flow Augmentation in the White Oak Creek Watershed}

Flow in WOC in the main ORNL plant area is augmented by the disposal of water imported for plant processes, potable supplies, and sanitary use. The flow is complex because of the effects of storm drainage, leakage into and out of an extensive system of underground pipes, and the increased permeability of disturbed subsurface materials along pipe lines and within construction sites. However, the discharge data from the five USGS stations in the vicinity of the main plant permit the isolation of flow from contributing areas where the majority of plant effluents and imported water enter the surface-water system. Figure 19 shows hydrographs of monthly mean discharge at monitoring stations GS3 (7500 Bridge) on WOC downstream from the main plant area, GS4 on the NWT, GS1 on First Creek, GS5 on WOC below its confluence with Fifth Creek, and the difference between flow at GS3 and the sum of the three upstream stations. This difference, consistently above $2 \mathrm{cfs}$, includes runoff from the contributing area between the three upstream stations and GS3 (approximately 0.18 $\mathrm{mi}^{2}$ ), as well as, and most significantly, the three major effluent discharges regulated under the ORNL NPDES permit: the STP, the CYRTF, and the NRWTF. These three facilities collectively release, on the average, approximately $1.1 \mathrm{cfs}$. This value was derived from the NPDES permit renewal application.

Figure 20 shows monthly mean discharge at WOC station GS5 compared to discharge at station GS6 which is outside the east gate of the main plant and upstream of most plant activities and effluents. The difference in flow between these stations includes the runoff from the contributing drainage area between the stations (approximately $0.8 \mathrm{mi}^{2}$ ). This area drains Fifth Creek as well as a number of minor effluent discharges from ORNL facilities, including Category I and II outfalls, cooling water discharges, and miscellaneous source discharges. This difference (GS5-GS6) is also consistently above 2 cfs.

Flow in Melton Branch was augmented by effluent discharges of about $0.25 \mathrm{cfs}$ from the High Flux Isotope Reactor (HFIR) and about $0.08 \mathrm{cfs}$ from the Transuranium Processing Facility (TRU) until November 1986 when the HFIR was shut down and discharges were substantially reduced. The reactor began operating again in January 1990 and reached full power in May 1990. However, in February 1990, the NRWTF went on-line to treat dilute ORNL process waste streams. This facility now receives the waste effluents from both the TRU and HFIR, facilities which were previously routed to temporary holding ponds 7908 and 7909, and 7905, respectively, before being released to MB. Currently, MB receives blowdown from the HFIR, an unidentified process water discharge coming from the headwaters region of the tributary to MB near the HRT facility (see Borders et al. 1991 for explanation), and 
Table 10. Summary of rating tables published in previous 1991 and 1992 Annual Surface Water Hydrology Reports and revisions/additions included in the 1993 Annual Report

\begin{tabular}{|c|c|c|}
\hline TABLE NO. & SITE & STATUS ${ }^{1}$ \\
\hline D.1 & White Oak Dam (MS5)-low flow & NC \\
\hline D.2 & White Oak Dam (MS5)-high flow & NC \\
\hline D.3 & White Oak Creek (MS3)-low flow & NC \\
\hline D.4 & White Oak Creek (MS3)-high flow & NC \\
\hline D.5 & Melton Branch & NC \\
\hline D.6 & White Oak Creek Headwaters & NC \\
\hline D.7 & East Seep & NC \\
\hline D.8 & West Seep & NC \\
\hline D.9 & Raccoon Creek & NC \\
\hline D.10 & Ish Creek & NC \\
\hline D.11 & HRT monitoring station on Melton Branch tributary & NC \\
\hline D.12 & White Oak Creek tributary near SWSA 4 & NC \\
\hline D.13 & T2A near SWSA 4 southern boundary & NC \\
\hline D.14 & MB2 monitoring station on Melton Branch & NC \\
\hline D.15 & First Creek (GS1, USGS03536450) & REVISION \\
\hline D.16 & Upper Melton Branch (GS2, USGS03537100) & NC \\
\hline D.17 & 7500 Bridge (GS3, USGS03536550) & NC \\
\hline D.18 & Northwest Tributary (NWT) (GS4, USGS03536440) & REVISION \\
\hline D.19 & GS5 (USGS03536380) & NC \\
\hline D.20 & GS6 (USGS03536320) & NC \\
\hline D.21 & East Seven Tributary (GS16, USGS03537050) & NC \\
\hline D.22 & Center Seven H-flume (GS17, USGS03537200) & REVISION \\
\hline D.23 & Center Seven-V notch weir (GS17, USGS03537200) & NC \\
\hline D.24 & West Seven Tributary (GS18, USGS03537300) & NC \\
\hline D.25 & East and West Fork weirs, Walker Branch Watershed & ADDITION \\
\hline
\end{tabular}

${ }^{1} \mathrm{NC}=$ No Change; REVISION=Revised table; $\mathrm{ADDITION}=$ Rating Table not included in previous reports. Rating tables with status $=\mathrm{NC}$ are not published in this report. Refer to the 1992 report (ORNL/ER-123) and the 1993 report (ORNL/ER-166) for previously published tables. 


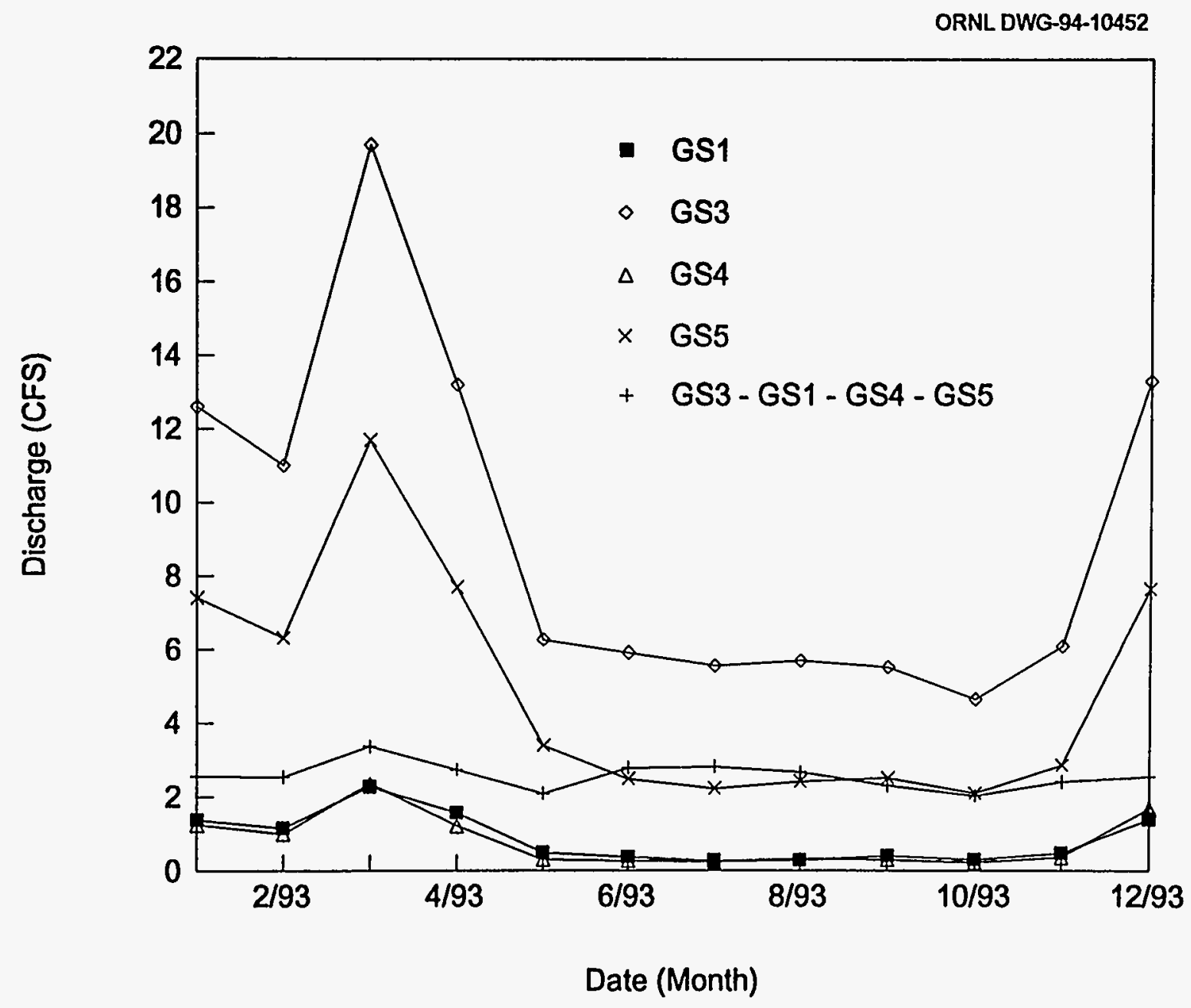

Fig. 19. Comparison of monthly mean discharge at USGS monitoring station GS1, GS3, GS4 and GS5. 


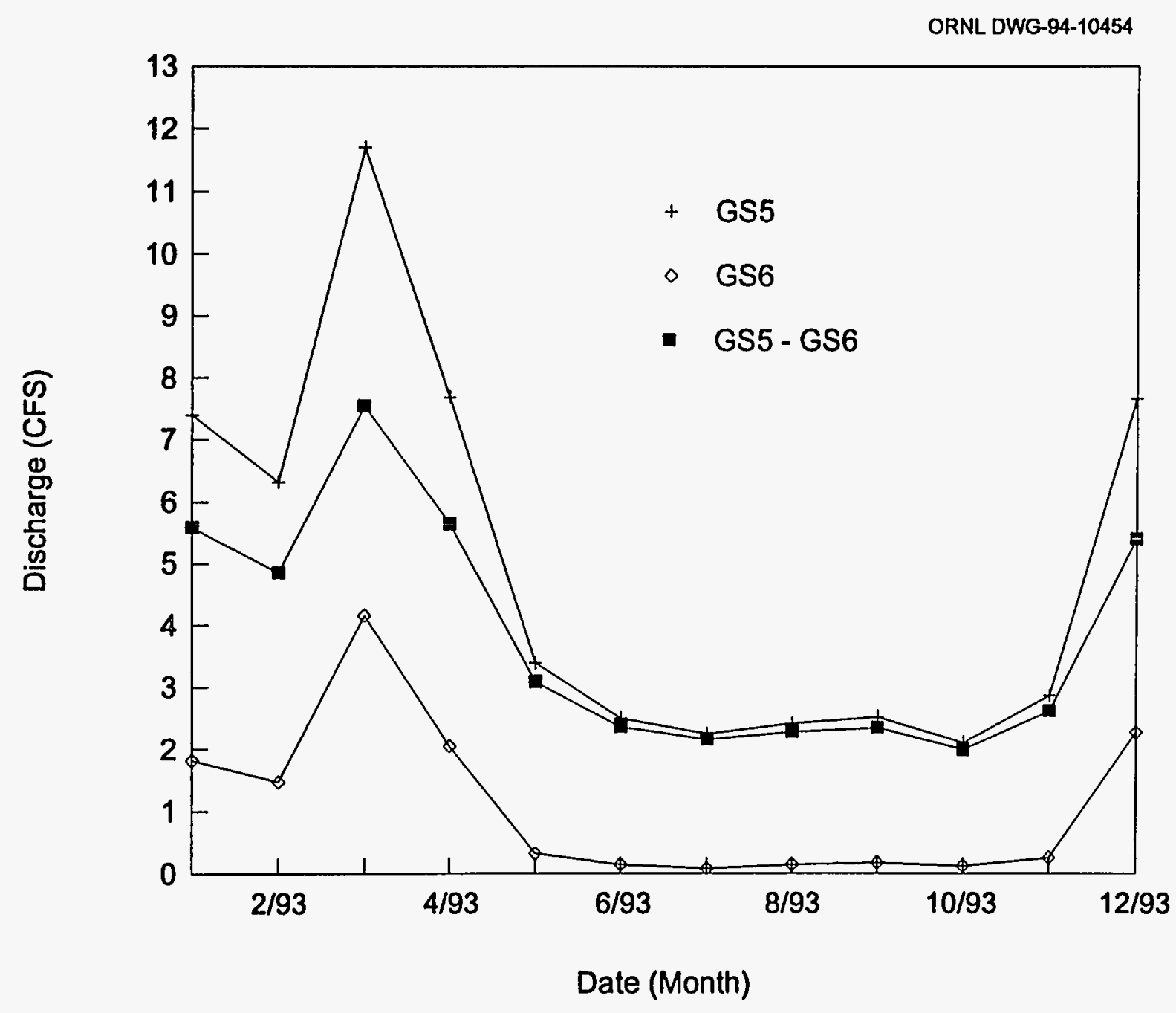

Fig. 20. Comparison of monthly mean discharge at USGS monitoring station GS5 and GS6. 
rainfall runoff. In addition, each summer, for at least the last four years (1990-1993), an unidentified discharge of approximately 0.5 to $1.5 \mathrm{cfs}$ has occurred for approximately the month of August (see Fig. 14).

\section{Outfalls to the White Oak Creek Flow System}

Water is supplied to the ORNL plant site from the DOE water treatment plant at an average rate of approximately 4.0 million gallons per day $(6.19 \mathrm{cfs})$. This water is then distributed to ORNL facilities through two separate systems: potable and process. Of the total amount of imported water, approximately $38 \%$ is lost to the atmosphere as evaporation via cooling towers. The remaining $62 \%$ (approximately $3.84 \mathrm{cfs}$ ) is subsequently discharged to the WOC surface-water system (Kasten 1986). According to Loar (1991), approximately $30 \%$ and $36 \%$ of the estimated total effluent volume to the WOC system are contributed by the cooling and process systems, respectively. Discharges from the STP, the steam plant, and leakage account for the remainder in approximately equal proportions (Kasten 1986). Process/imported water to the WOC watershed is described in detail in Borders et al. (1992).

\subsection{Surface Water Quality}

As part of the NPDES program, ESPS monitors surface-water quality for both radiological and chemical constituents at a number of sites in the WOC flow system. Additional water quality data have been collected at selected sites as part of the BMAP activities and other ERP studies.

Summaries of chemical and radiological data for in-stream monitoring sites appear in the previous ESPS quarterly environmental data reports (Goldberg 1992, 1993a-e) and also in the annual environmental reports for the Oak Ridge Reservation (ORR) (Energy Systems 1990, 1992, 1993).

Monthly discharge of selected radionuclides at the primary ESPS in-stream sites is calculated from flow and concentration values and presented in the quarterly environmental data reports. Figures 21-24 show the discharge of ${ }^{3} \mathrm{H}$, total radiological strontium, ${ }^{137} \mathrm{Cs}$, and ${ }^{60} \mathrm{Co}$ at WOC (MS3), MB (MS4), and WOD (MS5) for the 12-month reporting period (January-December, 1993). During 1993, as in 1992, the monthly radionuclide fluxes generally show a seasonal trend. As shown for the soluble contaminants ${ }^{3} \mathrm{H}$ and total strontium (Figs. 21 and 22, respectively), the minimum monthly fluxes occurred in September or October when conditions were the driest, and the maximum monthly fluxes occurred during the winter and spring when runoff was greatest.

Although ${ }^{137} \mathrm{Cs}$ shows some similarities, the ${ }^{137} \mathrm{Cs}$ flux at WOC (MS3) appears to be more randomly distributed, perhaps influenced more strongly by individual storms. The ${ }^{137} \mathrm{Cs}$ flux at WOD (MS5) was highest in March and lowest in July, however, at MS3 it was low in March and much higher in July (Fig. 24). During 1992 (Borders et al. 1993), lower WOC and WOL acted as a source of ${ }^{137} \mathrm{Cs}$ during the wet, non-growing season (winter) and as a sink during the dry, growing season (summer). For the current reporting period, lower WOC and WOL acted as a source of ${ }^{137} \mathrm{Cs}$ only during the months of January, March, and August, and most significantly in March. During every other month except May, lower WOC and WOL acted as a sink for a net loss of approximately $0.6 \mathrm{Ci}$. It appears that ${ }^{137} \mathrm{Cs}$ discharge from 


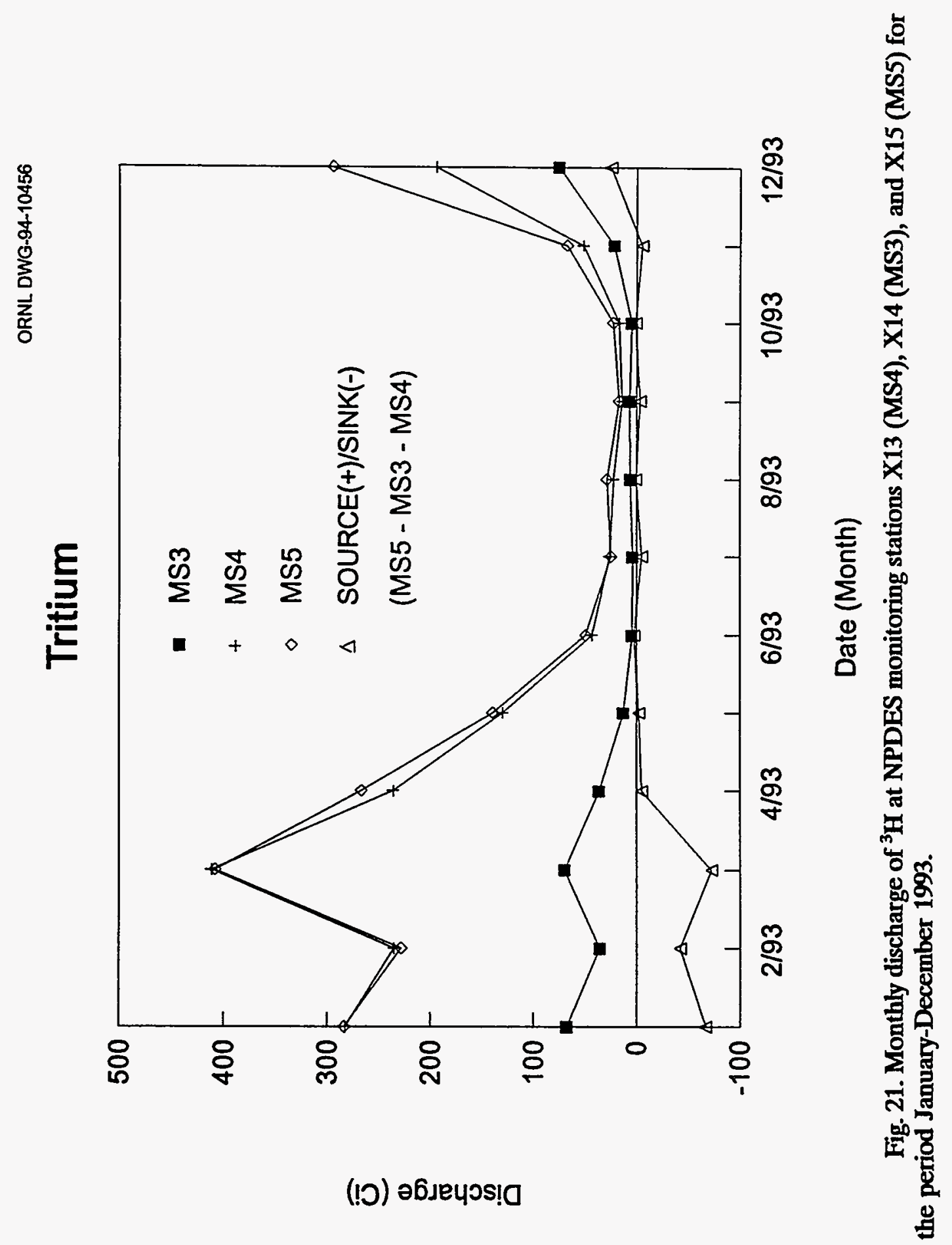




\section{Total Strontium}

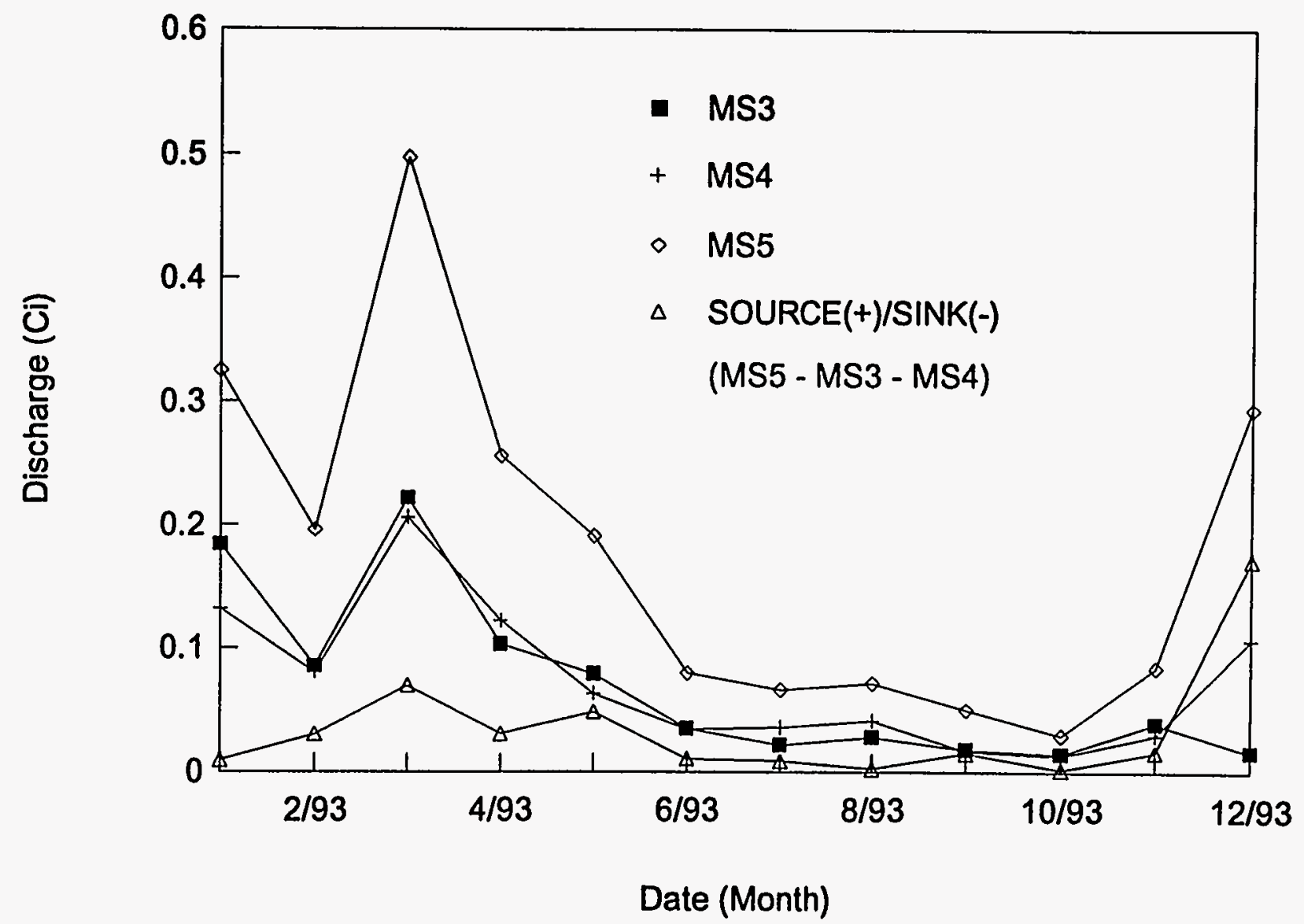

Fig. 22. Monthly discharge of total strontium at NPDES monitoring stations X13 (MS4), X14 (MS3), and X15 (MS5) for the period January-December 1993. 


\section{Cesium-137}

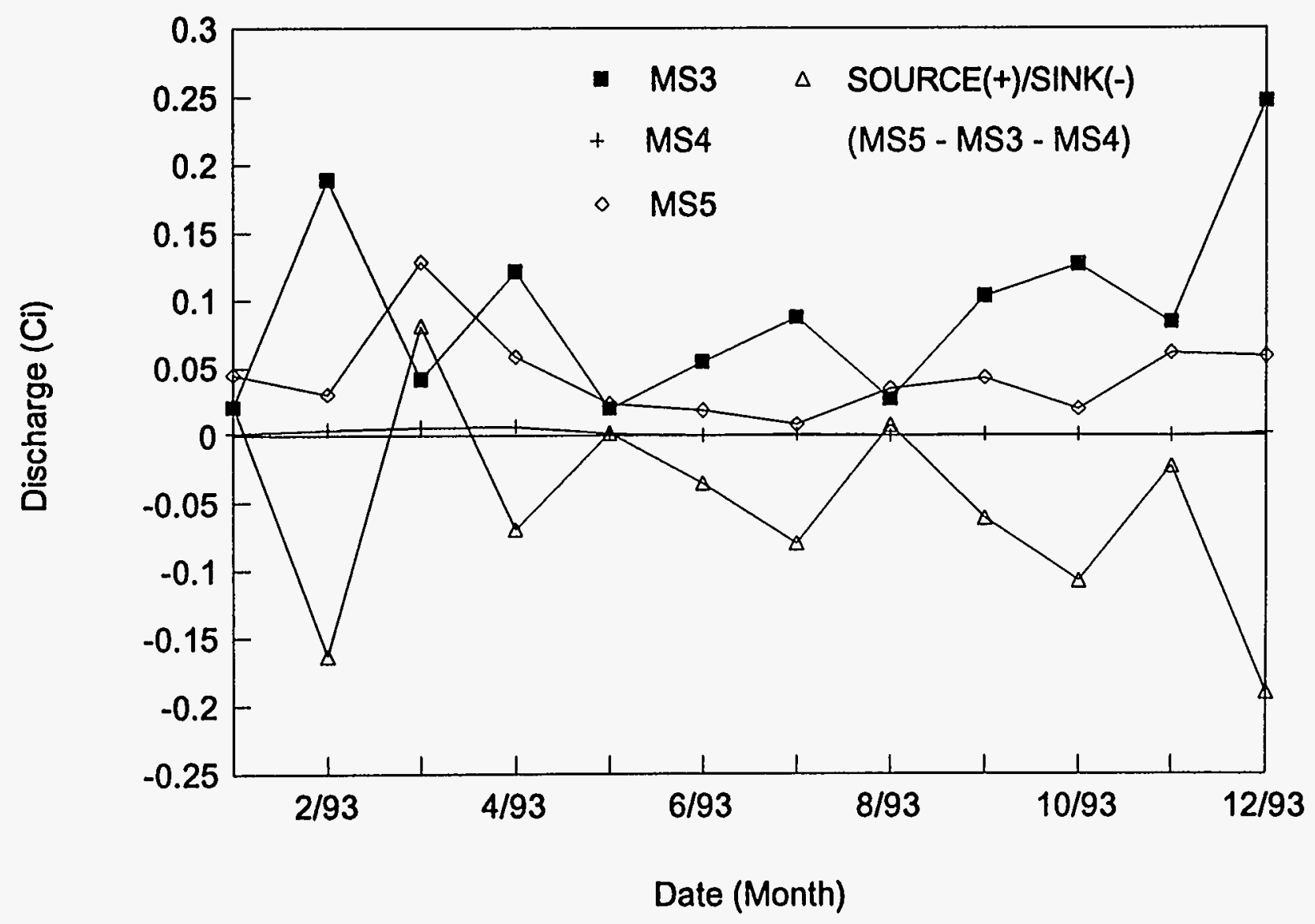

Fig. 23. Monthly discharge of ${ }^{137} \mathrm{Cs}$ at NPDES monitoring stations X13 (MS4), X14 (MS3), and X15 (MS5) for the period January-December 1993. 


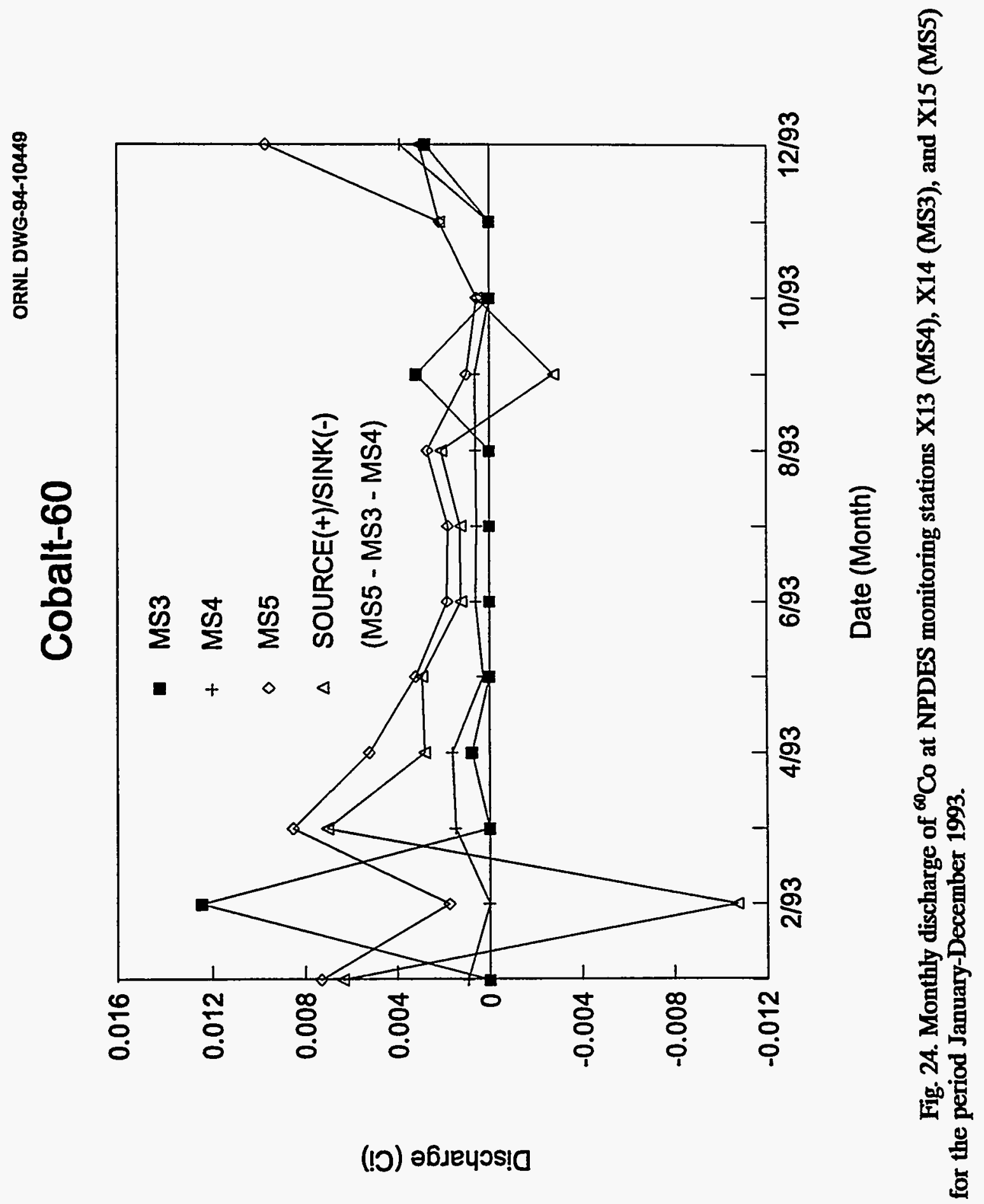


WOD is somewhat independent of input from WOC and more dependent on seasonal factors and individual storm characteristics.

In 1991 and 1992 , maximum ${ }^{60} \mathrm{Co}$ fluxes at WOD tended to occur 1-2 months after peak monthly flows. However, this pattern was more prevalent in 1991 than in 1992. For the current reporting period (1993), this pattern no longer prevails, and ${ }^{60} \mathrm{Co}$ fluxes roughly follow seasonal trends: higher disharges during wet months and lower discharges during dry months (Fig. 24). The major source of ${ }^{60} \mathrm{Co}$ is a groundwater seep in WAG 7 that drains to a small ungaged tributary to WOC. Perhaps its character is changing over time making the groundwater response from this seep less delayed relative to surface-water discharge.

Raccoon Creek receives surface runoff and, presumably, groundwater recharge from the western portion of SWSA 3. All other drainage from SWSA 3 is east toward the WOC watershed. The Raccoon Creek monitoring station facility was built to complete the Stream Sampling Network necessary to determine the extent of radionuclide migration from ORNL's SWSAs; however, composite sampling is not conducted at this site. ESD's Surface Water Hydrology Group collects discharge data at this site, and some evidence of contaminants has been detected in ESPS's water quality grab samples collected there.

\subsection{Contaminants in Sediments}

Studies of WOC streambed gravels as indicators of the degree and location of sources of radiological contaminants (Cerling 1985; Cerling and Spalding 1981) were continued during 1986-1987. Sobocinski et al. (1990) documented the results of studies of new sources of ${ }^{90} \mathrm{Sr}$ and ${ }^{137} \mathrm{Cs}$ in First Creek and upper WOC behind the ORNL main plant. Current studies to quantify radionuclide flux at selected sites based on radionuclide and metal concentrations on gravels and the associated streamflow, and to determine the mechanisms and rates of radionuclide and metal sorption and desorption on streambed gravels are being documented.

An aerial radiological survey was conducted during September and October of 1986 to provide detailed information on the nature and location of radiological contaminants in floodplain sediments. The study report by EG\&G Energy Measurements (Fritzsche, 1987) describes the survey methodology and shows detailed contours of total terrestrial gamma exposure rates and activities of ${ }^{137} \mathrm{Cs},{ }^{60} \mathrm{Co}$, and ${ }^{208} \mathrm{Th}$. In 1989 , a gamma survey of the ORNL facilities was conducted using a helicopter flying at an altitude of $300 \mathrm{ft}$. A comprehensive survey of the ORR was conducted in April 1992 (Maurer 1992). A gamma survey was conducted by helicopter at an altitude of $250 \mathrm{ft}$. In addition to the gamma survey, multispectral (MSS) imagery was taken at night from an altitude of $4000 \mathrm{ft}$ to search for seeps. MSS and color infrared were collected during the daytime at $3000 \mathrm{ft}$. Other flights flown at $6000 \mathrm{ft}$ collected MSS during the daytime and specific color photographs at various locations at varying heights for different facilities. A high-altitude $(43,000 \mathrm{ft})$ flight was made to survey the entire ORR. These data are being analyzed and will be included in the OREIS data base.

In August 1989, ESPS extensively sampled sediment at the monitoring stations on WOC (MS3) and MB (MS4). Multiple sediment samples were collected from the stilling pool upstream from the weir at MS3, and from the stilling pool upstream from the weir and from sediments downstream from the weir at MS4. Samples were analyzed for radionuclides, 
metals, and polychlorinated biphenyls (PCBs), to characterize the contaminated sediments as a waste for ultimate removal and disposal at a later time. Results of these analyses can be obtained from ESPS's Information Integration and Analysis Group. In addition, sediment samples have been collected from stilling pools at major surface-water monitoring stations by the WAG 2/SI program for similar analyses and for verification of earlier results.

As part of the Clinch River RFI [Resource Conservation and Recovery Act (RCRA) Facility Investigation], sediment sampling was conducted in the WOCE during the summer of 1990. Results of initial core sampling near the mouth of the embayment revealed elevated activities of ${ }^{137} \mathrm{Cs}$ for surface sediments. This finding prompted additional surface sediment and core sampling in the embayment. Subsequent sediment samples were analyzed for a wide range of contaminants including radionuclides, metals, and organics.

Preliminary risk assessments for WAG 2 (Blaylock et al. 1992) have indicated that the primary threat to human health is from direct exposure to gamma radiation. Therefore, in order to map the gamma-emitting sources in the soils and sediments in the WOC floodplain, a radiation walkover survey was conducted in the spring of 1992 (Clapp 1992). The results of the survey have been used to guide preliminary soil and sediment sampling for these gamma-emitting contaminants (primarily ${ }^{137} \mathrm{Cs}$ ). 


\section{DATA PROCESSING AND QA/QC}

\subsection{DATA PROCESSING}

\subsubsection{Stream Discharge Data}

The ESD Surface Water Hydrology Group collects stream stage data at flumes and weirs. These data are measured and recorded by either of two types of monitoring systems. Some sites are equipped with electronic data loggers and submerged pressure transducers that record data on electronic data storage packs, and some are equipped with mechanical float and pulley recorders that record data by punching paper tapes. After the paper punch tapes are translated and the data storage packs are downloaded, data processing for both methods is identical.

Computer files of raw, unaltered stage data are archived. The data are then reduced by removing redundancies. This reduction is done by producing files of breakpoint data with a program called EZ-BRK3 (Craig and Demaree, 1992a) written for ESD by Environmental Consulting Engineers (ECE). At this point in the processing procedure, the stage data are corrected according to weekly visual inspections of staff gage readings. The stage data are then processed to produce reports of discharge data with the REPORTER program, also developed by ECE. Hydrographs of the data are produced and compared with field notes to find inaccuracies such as those caused by debris clogging flow-measurement structures, faulty equipment, and submergence. Data are corrected when possible and, if the data cannot be corrected, they are removed from the record. Estimates, by hydrograph comparison and examination of precipitation records, using data from stations in the immediate vicinity, are then made. For the MS4 site on Melton Branch, all high-flow data are adjusted, according to the extended rating, to account for submergence effects. In addition, high flow-data at MS3 are checked for submergence, and discharge data are adjusted with an extended rating, when necessary.

\subsubsection{Precipitation Data}

Raingage charts are collected weekly from nine raingage sites equipped with Belfort Universal Recording Raingages. These charts are digitized to produce raw breakpoint data using RNF-DIG (Craig and Demaree 1992b). The breakpoint data are then converted into monthly reports of daily rainfall totals using PFREQ (Wilson 1992). The PFREQ program also has the ability to produce reports in the Terrestrial Ecology and Hydrology Model format.

Rainfall data for a site are validated by comparing the PFREQ-generated, daily rainfall totals for a site to the site's original raingage charts. Comparison of data from site to site is also done as an additional check. Original raingage charts are archived, and hardcopies of monthly reports of daily totals are retained. Computer files of the monthly reports and the breakpoint data used to create the reports are maintained by the ESD Surface Water Hydrology Group. 


\subsubsection{Software Systems}

In addition to the software packages, described in the previous section, that are used to process the streamflow and meteorological data collected by the ESD Surface Water Hydrology Group, the data may also be processed into LOTUS 1-2-3 or Statistical Analysis System files. The data, for the most part, are processed on personal computer systems. Data are stored on Bernoulli cartridges, floppy, and hard disks. Copies of the files are maintained with each notebook containing reports (listings) of the data. Copies are maintained in separate locations to protect against potential loss of data. Descriptions of the data backup and security procedures used in the ESD Surface Water Hydrology Group are contained in the "Surface Water Flow and Quality Measuring Sites and Surface Water Data Processing and Interpretation" Quality Assurance plan.

\subsection{DATA AVAILABILITY}

\subsubsection{Environmental Sciences Division}

For several years, the Surface Water Hydrology Group, Environmental Sciences Division has collected and processed discharge data at a number of stations in the WOC watershed and vicinity for modeling studies, independent research, and environmental restoration activities. Discharge data are available in raw-stage data format, hourly or daily discharge, and in hardcopy or computer formats. The ESD surface-water monitoring stations, for which data are available, have been described in previous reports (Borders et al. 1993). However, new stations and those with a change in monitoring status are documented in this report (Appendix B), with changes to monitoring station descriptions and additions noted in italics.

Nine precipitation gages in the WOC watershed and vicinity are operated by ESD's Surface Water Hydrology Group. Daily precipitation data collected at the Oak Ridge NOAA/ATDD station are available from the ESD Surface Water Hydrology Group.

In addition to surface-water discharge and precipitation data, ESD's Surface Water Hydrology Group collects meteorological data. Wind speed and direction, temperature, pan evaporation, solar radiation, and humidity data are available from a number of sites. However, the period of record varies from station to station, and some records are discontinuous.

Quarterly interim data reports have been published by the ESD Surface Water Hydrology Group in 1992 and 1993. These reports currently present daily discharge data at seven ESD and six USGS surface-water monitoring stations and daily precipitation totals at nine ESD raingages located in the vicinity of the WOC watershed and the NOAA/ATDD site located in the city of Oak Ridge. The data are presented in an informal manner in order to facilitate timely dissemination to potential users with multiple data needs. All data presented in the quarterly reports are provisional and subject to revision until published in the annual hydrologic data summary report (e.g., Borders et al. 1993). Reports are released near the middle of each following quarter. 


\subsection{U. S. Department of the Interior, Geological Survey}

Surface-water discharge and precipitation data are available from the USGS for a number of stations on the WOC watershed and the ORR. In addition, data on water quality, sediment, groundwater level, groundwater quality, and chemical quality of precipitation are available from the USGS for stations in Tennessee and are published in annual Water Resources Data Reports for the Water Year (USGS 1992, 1993, 1994).

All USGS surface-water discharge data published in this report, and data on precipitation from the 7500 Bridge station, are available by remote access to the USGS computer system based in Nashville, Tennessee. Data are available in unit values (5 to $15 \mathrm{~min}$ ) at selected stations and daily values for all stations. Rating tables (see Tables D.15-D.24, Appendix D in Borders et al. 1993), and the data collected for the development of the tables, are available for most surface-water monitoring stations in the system. In addition, near real-time discharge data are available from the 7500 Bridge monitoring station (GS3, USGS 03536550) connected to the USGS computer system by satellite telemetry via a data collection platform (DCP). The 7500 Bridge (GS3) station is the only such station in the WOC watershed on a DCP, thereby providing near real-time data (15-min delay) under high-flow conditions. The 7500 Bridge monitoring station also has a precipitation gage connected to the DCP with the capability to provide near real-time rainfall data at 15 -min intervals. These data (discharge and precipitation) are also available from the ORNL Consolidated Data Base management system.

\subsubsection{Environmental Surveillance Section}

The two primary monitoring activities of the ESPS are effluent monitoring and environmental surveillance. The general activities of the ESPS for the FY 1993 reeporting period are presented in their annual environmental report (i.e., Kornegay 1992).

\subsubsection{Oak Ridge Environmental Information System}

Many ORNL programs collect and report hydrologic data for a number of reasons. The OREIS is the repository of all validated data information generated by activities related to the ERP. The Document Management Center is a repository for all published reports produced for the program and for any other pertinent publications. The Document Management Center also indexes unpublished information (e.g., project plans and field notebooks) generated by the program. The OREIS numeric data base is a central repository for technical data generated in the ERP and data from other studies of interest. Data and the associated data management systems, prior to the OREIS system, used by the ERP have been documented in several annual reports (Voorhees et al. 1988, Voorhees et al. 1989, Hook et al. 1990).

\subsection{QUALTTY ASSURANCE/QUALITY CONTROL}

Quality assurance/quality control (QA/QC) for data collection and data processing in the ESD Hydrologic Data Center is governed by a quality assurance plan (Clapp and Borders 1992) developed to comply with the ORNL Quality Assurance Manual. In addition, a 
QA/QC plan for the WAG 2 RI Plan (ORNL 1990) and the ERP QA/QC Plan also apply to data collected in the surface-water monitoring project. Standard operating procedures for the WAG 2 investigations have also been developed and published as a controlled document for use by WAG 2 staff, with surface water hydrology-related procedures included in Section 3200 . Quality control is achieved through several steps. Procedures and guidelines have been developed covering data collection and data processing from the point of data origination in the field to final report preparation. Data verification is mentioned in the data processing section of this report. 


\section{SUMMARY AND RECOMMENDATIONS}

The collection and reporting of quality hydrologic data are essential to fulfilling the goals of the ER monitoring program to support a mass balance approach to determining sources and sinks of contaminants in the WOC system. This process includes defining and quantifying the input of wastes from ORNL WAGs and assessing the release of contaminants from the WOC system, because surface water is the primary pathway for the release of contaminants from the WOC system to off-site areas. The data are also used for the engineering design of remedial measures, evaluation of the effectiveness of past remediation measures, and prediction of remediation performance into the future.

\subsection{PROGRESS DURING THE PAST YEAR}

The network of raingages on and in the vicinity of the WOC watershed is currently being evaluated to determine optimum gage placement based on the number of gages, access capability (and restrictions), and spatial distribution. There are six raingages on the WOC watershed (counting the USGS gage at 7500 Bridge). Five of those gages are in Melton Valley and the sixth is near the water gap in Haw Ridge. In addition, two of these gages are in close proximity near WOD, the outlet of the drainage basin; no gages are located in the headwaters area of WOC. Therefore, one of the two gages near WOD (ETF) will soon be relocated to the WOC headwaters area. Other gages are also being evaluated for possible relocation.

Surface Water monitoring system upgrades have been supported in recent years by staff and by availability of data (discharge frequency analyses for sizing of flow measurement structures). The Northwest Tributary monitoring station is scheduled to be upgraded this summer with channel improvement and installation of a stilling well and upgraded sampling and data collection instrumentation planned. In addition, upgrades to three smaller tributary monitoring stations are planned for the near future.

The removal of deposited sediment from the stilling pools at MS3 and MS4 is in the planning stages. The responsibility for this effort recently shifted from the OECD to the ERP due to the intent to remove these two stations from the NPDES monitoring network (OECD's regulatory driver). An engineering project has been initiated and funding has been secured. A number of alternatives have been evaluated, NEPA documentation has been approved, and the final decision process is pending. Removal of the sediments is tentatively scheduled for the period August to October, 1994 to take advantage of seasonal low flows.

An extended rating was developed for the WOC MS3 surface-water monitoring station to adjust discharge calculations under submerged conditions. The extended rating is similar to that developed previously for the MB MS4 monitoring station. Adjustments were made to discharge data collected during the extreme storm events of December 4, 1993 and March 23, 1994.

Progress has been made by the USGS in rating the high-flow control devices at the WOC MS3 and MB MS4 monitoring stations. Results of measurements collected at MS4 compare 
favorably with discharge calculations derived from the extended rating used by the ESD Surface Water Hydrology group. At MS3, discharge measurements did not agree favorably with discharge calculated by ESD. Presumably, this was due to extreme turbulence over the broad-crested weir (the measurement location) during discharge measurements. However, a footbridge has been installed downstream of the monitoring station to facilitate the measurement directly from the stream where velocities are lower and more uniform. These efforts will continue into FY 1995.

The USGS has determined a practical method for measuring discharge at WOD (MS5) in order to rate the high-flow control device. An acoustic velocity meter (Neil Brown meter) will be utilized to measure velocities (and hence discharge) downstream from the sluice gates. Velocities in this section are too low for the standard Price current meter but within the applicable range of the Neil Brown meter. Preliminary tests have been made and field measurements will begin as early as this summer.

Walker Branch watershed discharge data (East and West forks) have been processed for CY 1993 by the Surface Water Hydrology Group, Environmental Sciences Division. These data are published in this report. Raw stage data (punch tapes) previously were being collected, processed, and archived but were not included in data reports. These two monitoring stations have the longest continuous period of record of any gages on the ORR and support a long-term ecosystem research project initiated in 1967.

The dissemination of quality hydrologic data to multiple users and programs continues to be the primary goal of this effort. Among the projects provided with data in 1993 were the WAG 2/SI Seep Task sampling initiative and sediment sampling and sediment transport modeling tasks, the ERMA report, other WAG investigations, Environmental Compliance for radiological analyses, and several groundwater investigations (including groundwater modeling of Melton Valley). Quarterly provisional hydrologic data reports continued to be issued in FY 1993, making data available to more users (the distribution list was expanded each quarter). These interim data reports are intended to provide provisional hydrologic data to potential users on an informal basis in a timely manner.

In FY 1994, the Tributary Assessment Task was established as a separate task from the Hydrologic Monitoring component of the WAG 2 program. Four tributary sites have been intensively sampled during storm events to characterize contaminant transport under a broad range of flow conditions and to quantify mass flux of contaminants migrating off-site via the surface-water pathway.

\subsection{RECOMMENDED IMPROVEMENTS}

\subsection{Issues within the ERP Hydrologic Monitoring Activity}

Several activities should be initiated to improve the quality and the appropriateness of the data generated for ERP functions. The activities listed below can be accomplished by ESD's Surface Water Monitoring staff in concert with other ERP groups. 
- Integration of data into a Geographic Information System (GIS). Surface-water data need to be added to the same systems currently used for analyzing and reporting groundwater data. Some progress has been made in linking ARC/INFO (the WAG 2 GIS) to MAPINFO. MAPINFO is the personal computer-based GIS currently used for analyzing and reporting much of WAG 2's and ORNL's groundwater data. WAG 2 staff in ESD's Surface Water Hydrology Group are being trained in the use of MapInfo as a tool for mapping, analyzing, and documenting hydrologic data. Efforts are currently being made to form small working groups to coordinate these activities between the various ORNL divisions and disciplines.

- Reconstitute the Ad Hoc Committee. This working group of ESD, ESPS, and Engineering staff, formed in 1990 to evaluate upgrades to surface-water monitoring stations on small tributaries at ORNL, has successfully evaluated design alternatives and made recommendations for one site. However, the evaluation process for upgrades to several other sites has not been duplicated, though the design process is scheduled to proceed. Moreover, the complicated issues described in Sect. 4.2 .2 have not been properly addressed.

- Coordination of surface-water monitoring activities at ORNL. A comprehensive surfacewater monitoring program, similar to the groundwater coordination efforts at ORNL, is needed to provide the data products required to satisfy various programs' goals while eliminating redundancy. A Comprehensive Watershed Hydrologic Monitoring Plan (CWHMP)is currently being developed for the ORNL ER Program. The purpose of the CWHMP is to integrate the surface-water monitoring programs of ER, OECD, ESD, and the USGS into a comprehensive monitoring system that meets the objectives of all groups and the needs of a reservation-wide surface-water monitoring program.

\subsubsection{Issues for Upper Level Management Approval}

This section describes improvements that will probably require decisions and assistance by upper level management within the ERP and ORNL if project goals are to be fully accomplished.

- Resolution of sedimentation problems at flow monitoring sites. Sediments, which are contaminated at most sites in the WOC flow system, have filled the stilling pools upstream from weirs and are adversely affecting the accuracy of discharge measurements. Some progress has been made (see Sect. 4.1), and if the current proposed schedule can be adhered to, deposited sediments will be removed from major monitoring stations this summer. However, this situation will recur in 5-10 years without the adoption of a watershed management program to maintain adequate operating conditions at all sites in the surface-water monitoring system.

- Regulatory guidance on manual methods and engineered structures (e.g., passing sediment downstream or installation of plugs in control structures) is needed on issues pertaining to sediment removal and disposal, and on mitigation issues. Some progress has been made here through the process of NEPA documentation, however, the process has been slow, particularly where sediment is contaminated (most sites). This effort is 
being coordinated with ESD hydrologists, ESPS, ORNL Engineering, and the ORNL Office of Environmental Compliance and Documentation. Alternatives are being evaluated for removal and disposal/storage of sediments.

- Resolution of tailwater problems at the MB (MS4) monitoring station. Discharge data collected from station MS4 have shown to be grossly in error during high-flow conditions because of submergence of the broad-crested weir. A number of measures have been employed or proposed to improve data accuracy, but they have not actually corrected the problem. An extended rating, which was developed theoretically using the upstream control above its intended range, has been used by ESD to improve the accuracy of highflow data. This extended rating is currently being field-verified by the USGS. This effort, to verify its accuracy or adjust it accordingly, will be completed in FY 1995. However, the monitoring station should be redesigned to establish a permanent hydraulic control at the upstream location (current low-flow location). An alternative is to remove a section of the concrete trunk line downstream crossing the channel to improve channel capacity enough to keep the upstream control from submerging. However, this trunk line is potentially contaminated.

- Elimination of redundancy in data collection. Currently, the compliance division collects flow data at numerous sites where ERP also collects data. ERP must continue to collect data as long as the compliance data logging system and processing systems do not provide for certain site-specific adjustments such as tailwater corrections, near real-time data, and finer resolution for modeling needs (i.e., hourly averages). Coordination of surface-water monitoring on a watershed scale should be developed under the direction and support of the upper levels of administration within ORNL (see Sect. 4.2.1). An alternative that should be given serious consideration is to have the USGS maintain all surface-water monitoring stations at ORNL for discharge data collection while providing the proper interfaces for water quality data collection by compliance organizations, ERP, and various research initiatives. The USGS is uniquely qualified to provide a high-quality, unbiased (disinterested) discharge data product.

\subsection{Future Activities}

The development and implementation of the CWHMP will continue to be supported. In addition, the collection and reporting of hydrologic data will continue to support ER's goals of identifying and characterizing sources of contamination migrating off-site via the surface-water pathway and the selection and subsequent evaluation of methods for their remediation.

Future hydrologic data summaries will continue to be produced as part of the WAG 2/SI Program. Staff, including subcontractors, will perform the data collection, compilation, and processing, as well as maintenance and oversight of surface-water monitoring system upgrade activities. The hydrologic data will be incorporated into annual Environmental Restoration Monitoring and Assessment (ERMA) reports that provide a comprehensive picture of ERP facilities at a watershed scale by identifying and interpreting spatial and temporal trends in contaminant movement within the WOC watershed. 


\section{REFERENCES}

Blaylock, B. G., M. L. Frank, F. O. Hoffman, L. A. Hook, G. W. Suter, and J. A. Watts. 1992. Screening of Contaminants in Waste Area Grouping 2 at Oak Ridge National Laboratory. ORNL/ER-58. Oak Ridge National Laboratory, Oak Ridge, Tennessee.

Boegley, W. J., et al. 1985. Characterization plan for Solid Waste Storage Area 6. ORNL/TM-9877. Oak Ridge National Laboratory, Oak Ridge, Tennessee.

Borders, D. M., C. B. Sherwood, J. A. Watts, and R. H. Ketelle. 1989. Hydrologic Data Summary for the White Oak Creek Watershed: May 1987-April 1988. ORNL/TM-10959. Oak Ridge National Laboratory, Oak Ridge, Tennessee.

Borders, D. M., S. M. Gregory, R. B. Clapp, B. J. Frederick, G. K. Moore, J. A. Watts, C. C. Broders, and A. T. Bednarek. 1991. Annual Hydrologic Data Summary for the Whiteoak Creek Watershed, Water Year 1990 (October 1989-September 1990). ORNL/ER-55. Oak Ridge National Laboratory, Oak Ridge, Tennessee.

Borders, D. M. S. M. Gregory, R. B. Clapp, B. J. Frederick, and J. A. Watts. 1992. Hydrologic data summary for the White Oak Creek Watershed at Oak Ridge National Laboratory, Oak Ridge, Tennessee (October 1990-December 1991). ORNL/ER-123. Oak Ridge National Laboratory, Oak Ridge, Tennessee.

Borders, D. M., J. A. Watts, R. B. Clapp, B. J. Frederick, and T. D. Moore. 1993. Hydrologic data summary for the White Oak Creek Watershed at Oak Ridge National Laboratory, Oak Ridge, Tennessee (January-December 1992). ORNL/ER-166. Oak Ridge National Laboratory, Oak Ridge, Tennessee.

Bos, M. G. 1990. Discharge Measurement Structures. 3rd revised edition. ILRI publication 20. International Institute for Land Reclamation and Improvement, Wageningen, The Netherlands.

Boyle, J. W., et al. 1982. Environmental analysis of the operation of the Oak Ridge National Laboratory (X-10 Site). ORNL-5870. Oak Ridge National Laboratory, Oak Ridge, Tennessee.

Cerling, T. E. and B. P. Spalding. 1981. Areal distribution of ${ }^{60} \mathrm{Co},{ }^{137} \mathrm{Cs}$, and ${ }^{90} \mathrm{Sr}$ in streambed gravels of the White Oak Creek Watershed, Oak Ridge, Tennessee. ORNL/TM-7318. Oak Ridge National Laboratory, Oak Ridge, Tennessee.

Cerling, T. E. 1985. Investigation of bedload transport of contaminated gravel in the White Oak Creek drainage. Summary Report to the Environmental Sciences Division. Oak Ridge National Laboratory, Oak Ridge, Tennessee.

Clapp, R. B. (ed.). 1992. Annual report of the Environmental Restoration Monitoring and Assessment Program at Oak Ridge National Laboratory for FY 1992. ORNL/ER-124. Oak Ridge National Laboratory, Oak Ridge, Tennessee. 
Clapp, R. B., and D. M. Borders. 1992. Quality assurance plan for Environmental Restoration Program (ERP) activities: Surface water flow and quality measuring sites and surface water data processing and interpretation. QAP-X-90-ES-079. Oak Ridge National Laboratory, Oak Ridge, Tennessee.

Clinch River Study Steering Committee. 1967. Comprehensive report of the Clinch River study. ORNL-4035. Oak Ridge National Laboratory, Oak Ridge, Tennessee.

Cox, D. K, N. D. Farrow, W. C. Kyker, M. A. Faulkner and L. M. Stubbs. 1991. The new definitive map of White Oak Lake. ORNL/TM-11204. Oak Ridge National Laboratory, Oak Ridge, Tennessee.

Craig, P. M. and L. K. Demaree. 1992a. Time series/hydrologic data reporting systems user's document. ECE-91-037. Environmental Consulting Engineers, Inc., Knoxville, Tennessee.

Craig, P. M. and L. K. Demaree. 1992b. Belfort rain gage charts digitizing program user's guide. ECE-91-038. Environmental Consulting Engineers, Inc., Knoxville, Tennessee.

Energy Systems (Martin Marietta Energy Systems, Inc.) 1985. Environmental monitoring report, United States Department of Energy Oak Ridge Facilities, calendar year 1984. ORNL-6209. Oak Ridge, Tennessee.

Energy Systems (Martin Marietta Energy Systems, Inc.). 1990. Oak Ridge Reservation environmental report for 1989, ES/ESH-13/V1. Oak Ridge National Laboratory, Oak Ridge, Tennessee.

Energy Systems (Martin Marietta Energy Systems, Inc.). 1992. Oak Ridge Reservation environmental report for 1990, ES/ESH-18. Oak Ridge National Laboratory, Oak Ridge, Tennessee.

Environmental Protection Agency (EPA). 1986. Authorization to discharge under the National Pollutant Discharge Elimination System, Permit No. TN0002941, Oak Ridge National Laboratory (X-10), and Fact Sheet, April 1, 1986, U.S. Environmental Protection Agency, Region IV. Atlanta, Georgia.

Fontaine, T. A. 1991. Monitoring and modeling contaminated sediment transport in the White Oak Creek watershed. ORNL/ER-65. Oak Ridge National Laboratory, Oak Ridge, Tennessee.

Frederick, R. H., V. A Myers, and E. P. Auciello. 1977. Five- to 60-minute precipitation frequency for the eastern and central United States. NOAA Technical Memorandum NWS HYDRO-35. Office of Hydrology, Silver Spring, Maryland.

Fritzsche, A. E. 1987. An aerial radiological survey of the White Oak Creek flood plain. Oak Ridge Reservation, Oak Ridge, Tennessee. EG\&G/Energy Measurements, Inc., EGG-10282-1136. 
Goldberg, P. Y. (coord.), R. C. Cooper, L. V. Hamilton, J. F. Hughes, B. M. Horwedel, R. S. Loffman, M. C. Salmons, M. M. Stevens, C. K. Valentine, and D. A. Wolf. 1992. Environmental surveillance data report for the first quarter of 1992 . ORNL/M-1757. Oak Ridge National Laboratory, Oak Ridge, Tennessee.

Goldberg, P. Y. (coord.), R. C. Cooper, L. V. Hamilton, J. F. Hughes, B. M. Horwedel, R. S. Loffman, M. C. Salmons, M. M. Stevens, C. K. Valentine, and D. A. Wolf. 1993a. Environmental surveillance data report for the second quarter of 1992. ORNL/M-1758. Oak Ridge National Laboratory, Oak Ridge, Tennessee.

Goldberg, P. Y. (coord.), R. C. Cooper, L. V. Hamilton, J. F. Hughes, B. M. Horwedel, R. S. Loffman, M. C. Salmons, M. M. Stevens and C. K. Valentine. 1993b. Environmental surveillance data report for the third quarter of 1992 . ORNL/M-1759. Oak Ridge National Laboratory, Oak Ridge, Tennessee.

Goldberg, P. Y. (coord.), R. C. Cooper, L. V. Hamilton, J. F. Hughes, B. M. Horwedel, R. S. Loffman, M. C. Salmons, M. M. Stevens and C. K. Valentine. 1993c. Environmental surveillance data report for the fourth quarter of 1992 . ORNL/M-1760. Oak Ridge National Laboratory, Oak Ridge, Tennessee.

Goldberg, P. Y. (coord.), S. E. Gheesling, J. C. Gideon, S. M. Gregory, L. V. Hamilton, B. M. Horwedel, R. S. Loffman, M. C. Salmons, and M. M. Stevens. 1993d. Environmental surveillance data report for the first quarter of 1993. ORNL/M-3022. Oak Ridge National Laboratory, Oak Ridge, Tennessee.

Goldberg, P. Y. (coord.), S. E. Gheesling, J. C. Gideon, S. M. Gregory, L. V. Hamilton, R. S. Loffman, M. C. Salmons, and M. M. Stevens. 1993e. Environmental surveillance data report for the second quarter of 1993. ORNL/M-3023. Oak Ridge National Laboratory, Oak Ridge, Tennessee.

Hershfield, D. M. 1961. Rainfall frequency atlas of the United States for durations from 30 minutes to 24 hours and return periods from 1 to 100 years. U.S. Department of Commerce, Weather Bureau Tech. Pap. No. 40. U.S. Government Printing Office, Washington, DC.

Hook, L. A., et al. 1990. Data base management activities for the Remedial Action Program at ORNL: Calendar year 1989. ORNL/ER-16. Oak Ridge National Laboratory, Oak Ridge, Tennessee.

Huff, D. D., and B. J. Frederick. 1984. Hydrologic investigations in the vicinity of the proposed central waste disposal facility, Oak Ridge National Laboratory, Tennessee. ORNL/TM-9354. Oak Ridge National Laboratory, Oak Ridge, Tennessee.

Kasten, J. L. 1986. Resource Management Plan for the Oak Ridge Reservation. ORNL/ESH-1/N21. Oak Ridge National Laboratory, Oak Ridge, Tennessee. 
Kolehmainen, S. E. and D. J. Nelson. 1969. The balances of ${ }^{137} \mathrm{Cs}$, stable cesium, and feeding rates of bluegill (Lepomis macrochirus Raf.) in White Oak Lake. ORNL-4445. Oak Ridge National Laboratory, Oak Ridge, Tennessee.

Kornegay, F. C. et al. 1992. Oak Ridge Reservation environmental report for 1991. Vol. 2: Data presentation. ES/ESH-22/V2. Martin Marietta Energy Systems, Inc., Oak Ridge, Tennessee.

Krumholz, L. A. 1954a. An ecological survey of White Oak Creek, 1950-1953. ORO-587, Vol. 1. U. S. Atomic Energy Commission, Division of Technical Information, Oak Ridge, Tennessee.

Krumholz, L. A. 1954b. An ecological survey of the limnology of White Oak Creek and Lake. ORO-587, Vol. 2. U. S. Atomic Energy Commission, Division of Technical Information, Oak Ridge, Tennessee.

Krumholz, L. A. 1954c. An ecological survey of the vertebrate fauna of White Oak Lake and environs. ORO-587, Vol. 3. U. S. Atomic Energy Commission, Division of Technical Information, Oak Ridge, Tennessee.

Lackey, J. B. 1957. The suspended microbiota of the Clinch River and adjacent waters in relation to radioactivity in the summer of 1956. ORNL-2410. Oak Ridge National Laboratory, Oak Ridge, Tennessee.

Loar, J. M. (ed.). 1991. Fifth Annual Report on the ORNL Biological Monitoring and Abatement Program. ORNL/M-1485. Oak Ridge National Laboratory, Oak Ridge, Tennessee.

Loar, J. M. (ed.). 1992. Sixth Annual Report on the ORNL Biological Monitoring and Abatement Program. ORNL/TM-12083. Oak Ridge National Laboratory, Oak Ridge, Tennessee.

Maurer, R. J. 1992. An aerial radiological survey of the Oak Ridge Reservation. EGG10617-1229. EG\&G Energy Measurements, Inc., Las Vegas, Nevada.

McMaster, W. M., and H. D. Waller. 1965. Geology and Soils of White Oak Creek Basin, Tennessee, ORNL/TM-1108, Oak Ridge National Laboratory, Oak Ridge, Tennessee.

McMaster, W. M. 1967. Hydrologic data for the Oak Ridge area, Tennessee. USGS Water Supply Paper No. 1839-N. U. S. Geological Survey, Washington, DC.

Oakes, T. W., et al. 1982. Technical background information for the ORNL Environmental and Safety Report, Vol. 4: White Oak Lake and Dam. ORNL-5681. Oak Ridge National Laboratory, Oak Ridge, Tennessee.

ORNL. 1990. Remedial investigation plan for Waste Grouping 2 at Oak Ridge National Laboratory, Oak Ridge, Tennessee. ES/ER-14\&D1. Environmental Restoration Program, Oak Ridge National Laboratory, Oak Ridge, Tennessee. 
Setter, L. R. and O. W. Kochtitzky. 1950. Studies of the White Oak Creek drainage system: 1. Drainage area of the creek and capacity of White Oak Lake. ORNL-562. Oak Ridge National Laboratory, Oak Ridge, Tennessee.

Sherwood, C. B. and J. M. Loar. 1986. Environmental data for the WOC/WOL watershed. ORNL/TM-10062. Oak Ridge National Laboratory, Oak Ridge, Tennessee.

Smith, M. S. 1945. Report on White Oak Creek dam structure and flood operation. CL-455. Nuclear Division-Union Carbide Corporation, Oak Ridge, Tennessee.

Sobocinski, R. W., T. E. Cerling, and S. J. Morrison. 1990. Sediment transport in a small stream based on ${ }^{137} \mathrm{Cs}$ inventories of the bed load fraction. Water Resources Research 26(6):1177-1187.

Solomon, D. K., G. K. Moore, L. E. Toran, R. B. Dreier, and W. M. McMaster. 1992. Status report: A hydrologic framework for the Oak Ridge Reservation. ORNL/TM-12026. Oak Ridge National Laboratory, Oak Ridge, Tennessee.

Swann, M. E., et al. 1942. Soil Survey Roane County Tennessee. U.S. Department of Agriculture, Bureau of Industry in Cooperation with Tennessee Agricultural Experiment Station and Tennessee Valley Authority. Washington, D.C.

Tschantz, B. A 1987. White Oak Creek hydrologic and spillway adequacy analysis. ORNL/SUB/87-32-CT 213V-1, The University of Tennessee. Knoxville, Tennessee.

Tschantz, B. A., and W. A. Rghebi. 1989. Hydrologic and Hydraulic Sensitivity Analysis for Supporting White Oak Dam Emergency Plan. The University of Tennessee, Civil Engineering Department, Knoxville, Tennessee.

USGS (U.S. Geological Survey). 1992. Water Resources Data Tennessee, Water Year 1991. USGS/WRD/HD-92/235. U. S. Geological Survey, Water Resources Division, Nashville, Tennessee.

USGS (U.S. Geological Survey). 1993. Water Resources Data Tennessee, Water Year 1992. USGS/WRD/HD-93/241. U. S. Geological Survey, Water Resources Division, Nashville, Tennessee.

USGS (U.S. Geological Survey). 1994. Water Resources Data Tennessee, Water Year 1993. USGS/WRD/HD-94/254. U. S. Geological Survey, Water Resources Division, Nashville, Tennessee.

Voorhees, L. D., L. A. Hook, M. J. Gentry, R. A. McCord, M. A. Faulkner, K. A. Newman, and P. T. Owen. 1988. Data base management activities for the Remedial Action Program at ORNL: Calendar year 1987. ORNL/TM-10694. Oak Ridge National Laboratory, Oak Ridge, Tennessee. 
Voorhees, L. D., et al. 1989. Annual report of data management activities for the Remedial Action Program at ORNL: Calendar year 1988. ORNL/TM-11147. Oak Ridge National Laboratory. Oak Ridge, Tennessee.

Webster, D. A., and M. W. Bradley. 1987. Hydrology of the Melton Valley RadioactiveWaste Burial Grounds at Oak Ridge National Laboratory, Tennessee, U.S. Geological Survey Open-File Report 87-686. Tennessee Water Resources Division, Nashville, Tennessee.

Wilson, J. M. 1992. User's Guide for PFREQ, Rainfall Analysis and Reporting Program. MMHE 1.09-002 (Rev. 1). Environmental Consulting Engineers, Inc., Knoxville, Tennessee. 
Appendix A

DAILY PRECIPITATION TOTALS FOR STATIONS IN THE WHITE OAK CREEK WATERSHED 
Table A.1. Daily precipitation totals at the First Creek (1ST) raingage for the period January-December 1993

(units =in)

\begin{tabular}{|c|c|c|c|c|c|c|c|c|c|c|c|c|}
\hline DAY & JAN & FEB & MAR & APR & MAY & JUN & JUL & AUG & SEP & OCT & Hov & DEC \\
\hline 1 & 0.00 & 0.00 & 0.00 & 0.11 & 0.00 & 0.00 & 0.00 & 0.00 & $0.01(e)$ & 0.00 & 0.00 & 0.00 \\
\hline 2 & 0.00 & 0.00 & 0.21 & 0.03 & 0.00 & 0.00 & 0.00 & 0.09 & $0.09(\mathrm{e})$ & 0.21 & 0.00 & 0.00 \\
\hline 3 & 0.00 & 0.00 & $0.57(c)$ & 0.00 & 0.03 & 0.00 & 0.00 & 0.00 & $1.22(\mathrm{e})$ & 0.00 & 0.00 & 0.28 \\
\hline 4 & 0.80 & 0.00 & $0.27(\mathrm{e})$ & 0.05 & 0.51 & 0.00 & 0.00 & 0.94 & $0.00(e)$ & 0.00 & 0.41 & 4.32 \\
\hline 5 & 0.19 & 0.00 & 0.00 & 0.47 & 0.00 & 0.00 & 0.00 & 0.07 & $0.00(e)$ & 0.00 & 0.42 & 0.01 \\
\hline 6 & 0.00 & 0.00 & 0.00 & 0.00 & 0.00 & 0.00 & 0.00 & 1.60 & $0.00(c)$ & 0.00 & 0.00 & 0.00 \\
\hline 7 & 0.32 & 0.00 & 0.05 & 0.00 & 0.00 & 0.00 & 0.00 & 0.00 & $0.00(e)$ & 0.00 & 0.00 & 0.00 \\
\hline 8 & 0.33 & 0.00 & 0.02 & 0.00 & 0.02 & 0.00 & 0.00 & 0.00 & $0.00(c)$ & 0.00 & 0.00 & 0.00 \\
\hline 9 & 0.00 & 0.00 & 0.00 & 0.90 & 0.00 & 0.00 & 0.02 & 0.00 & 0.00 & 0.32 & 0.00 & 0.22 \\
\hline 10 & 0.02 & 0.00 & 0.03 & 0.00 & 0.00 & 0.00 & 0.00 & 0.00 & 0.00 & 0.00 & 0.00 & 0.70 \\
\hline 11 & 0.72 & 0.64 & 0.00 & 0.00 & 0.00 & 0.00 & 0.00 & 0.30 & 0.00 & 0.18 & 0.00 & 0.01 \\
\hline 12 & 0.05 & 0.06 & 0.17 & 0.00 & 0.00 & 0.00 & 0.00 & 0.31 & 0.00 & 0.00 & 0.00 & 0.00 \\
\hline 13 & 0.01 & 0.00 & 0.00 & 0.00 & 0.48 & 0.19 & 0.13 & 0.29 & 0.00 & 0.00 & 0.00 & 0.00 \\
\hline 14 & 0.00 & 0.00 & 0.12 & 0.00 & 0.00 & 0.76 & 0.04 & 0.00 & 0.00 & 0.00 & 1.06 & 0.31 \\
\hline 15 & 0.00 & 0.02 & 0.73 & 0.89 & 0.00 & 0.02 & 0.67 & 0.00 & 0.46 & 0.03 & 0.24 & 0.10 \\
\hline 16 & 0.00 & 0.66 & 0.01 & 0.01 & 0.01 & 0.00 & 0.00 & 0.00 & 0.08 & 0.16 & 0.02 & 0.00 \\
\hline 17 & 0.00 & 0.00 & 0.30 & 0.00 & 0.00 & 0.00 & 0.51 & 0.10 & 0.00 & 0.04 & 0.27 & 0.00 \\
\hline 18 & 0.00 & 0.00 & 0.00 & 0.00 & 0.48 & 0.17 & 0.00 & 0.44 & 0.00 & 0.00 & 0.00 & 0.01 \\
\hline 19 & 0.05 & 0.00 & 0.00 & 0.00 & 0.46 & 0.25 & 0.01 & 0.00 & 0.00 & 0.00 & 0.00 & 0.00 \\
\hline 20 & 0.05 & 0.02 & 0.09 & 0.86 & 0.00 & 0.00 & 0.00 & 0.11 & 0.00 & 0.00 & 0.00 & 0.57 \\
\hline 21 & 0.41 & 1.48 & 0.00 & 0.00 & 0.33 & 0.03 & 0.00 & 0.00 & 0.00 & 0.74 & 0.00 & 0.06 \\
\hline 22 & 0.00 & 0.00 & 0.14 & 0.00 & 0.00 & 0.00 & 0.00 & 0.00 & 0.00 & 0.00 & 0.00 & 0.00 \\
\hline 23 & 0.00 & 0.00 & 2.24 & 0.00 & 0.00 & 0.00 & 0.00 & 0.00 & 1.24 & 0.00 & 0.00 & 0.02 \\
\hline 24 & 1.05 & 0.00 & 0.00 & 0.00 & 0.00 & 0.00 & 0.00 & 0.00 & 0.00 & 0.00 & 0.00 & 0.00 \\
\hline 25 & 0.00 & 0.04 & 0.02 & 0.75 & 0.13 & 0.00 & 0.00 & $0.00(e)$ & 0.39 & 0.00 & 0.00 & 0.02 \\
\hline 26 & 0.00 & 0.42 & 0.60 & 0.19 & 0.06 & 0.00 & 0.00 & $0.00(e)$ & 0.30 & 0.00 & 0.61 & 0.00 \\
\hline 27 & 0.00 & 0.00 & 0.45 & 0.00 & 0.00 & 0.00 & 0.01 & $0.00(e)$ & 0.53 & 0.00 & 0.43 & 0.00 \\
\hline 28 & 0.00 & 0.00 & 0.00 & 0.00 & 0.00 & 0.00 & 0.00 & $0.00(\mathrm{e})$ & 0.00 & 0.00 & 0.00 & 0.83 \\
\hline 29 & 0.00 & & 0.00 & 0.00 & 0.02 & 0.00 & 0.00 & $0.00(e)$ & 0.00 & 0.24 & 0.00 & 0.03 \\
\hline 30 & 0.00 & & 0.00 & 0.00 & 0.11 & 1.21 & 0.00 & $0.00(\mathrm{e})$ & 0.00 & 0.46 & 0.00 & 0.00 \\
\hline 31 & 0.00 & & 0.92 & & 0.59 & & 0.00 & $0.00(0)$ & & 0.07 & & 0.00 \\
\hline TOTAL & 3.90 & 3.34 & 6.94 & 4.26 & 3.23 & 263 & 1.39 & 4.25 & 4.32 & 245 & 3.46 & 7.49 \\
\hline MEAN & 0.12 & 0.12 & 0.22 & 0.14 & 0.10 & 0.09 & 0.04 & 0.14 & 0.14 & 0.08 & .12 & 0.24 \\
\hline MAX & 1.05 & 1.48 & 224 & 0.90 & 0.59 & 1.21 & 0.67 & 1.60 & 1.24 & 0.74 & 1.06 & 4.32 \\
\hline
\end{tabular}

(e) - Data from station other than 1ST 
Table A.2. Daily precipitation totals at the Engineering Test Facility (ETF) raingage for the period January-December 1993

(units=in)

\begin{tabular}{|c|c|c|c|c|c|c|c|c|c|c|c|c|}
\hline DAY & JAN & FEB & MAR & APR & MAY & JUN & JUL & AUG & SEP & OCT & NOV & DEC \\
\hline 1 & 0.00 & 0.00 & 0.00 & 0.08 & 0.00 & $0.00(e)$ & 0.00 & 0.00 & 0.00 & 0.00 & 0.00 & 0.00 \\
\hline 2 & 0.00 & 0.00 & 0.23 & 0.05 & 0.00 & $0.00(\mathrm{e})$ & 0.00 & 0.07 & 0.06 & 0.28 & $0.00(\mathrm{c})$ & 0.00 \\
\hline 3 & 0.00 & 0.00 & 0.60 & 0.00 & 0.03 & $0.00(e)$ & 0.00 & $0.00(c)$ & 1.09 & 0.00 & $0.00(\mathrm{c})$ & 0.27 \\
\hline 4 & 0.62 & 0.00 & 0.30 & 0.01 & 0.54 & $0.00(e)$ & 0.00 & $0.93(c)$ & 0.00 & 0.00 & $0.40(e)$ & 4.53 \\
\hline 5 & 0.23 & 0.00 & 0.02 & 0.51 & 0.00 & $0.00(\mathrm{e})$ & 0.00 & $0.00(e)$ & 0.00 & 0.00 & $0.47(\mathrm{e})$ & 0.04 \\
\hline 6 & 0.00 & 0.00 & 0.00 & 0.00 & 0.00 & $0.00(\mathrm{c})$ & 0.00 & $1.57(\mathrm{e})$ & 0.00 & 0.00 & $0.00(\mathrm{c})$ & 0.00 \\
\hline 7 & 0.36 & 0.00 & 0.03 & 0.00 & 0.00 & $0.00(e)$ & 0.00 & $0.00(c)$ & 0.00 & 0.00 & $0.00(e)$ & 0.00 \\
\hline 8 & 0.36 & 0.00 & 0.02 & 0.00 & 0.02 & $0.00(e)$ & 0.00 & $0.00(c)$ & 0.00 & 0.00 & $0.00(e)$ & 0.00 \\
\hline 9 & 0.00 & 0.00 & 0.00 & 0.94 & 0.00 & 0.00 & 0.02 & $0.00(\mathrm{c})$ & 0.00 & 0.37 & $0.00(e)$ & 0.20 \\
\hline 10 & 0.03 & 0.00 & 0.00 & 0.00 & 0.00 & 0.03 & 0.00 & $0.00(e)$ & 0.00 & 0.00 & $0.00(e)$ & 0.71 \\
\hline 11 & 0.77 & 0.66 & 0.00 & 0.00 & 0.00 & 0.00 & 0.00 & 0.27 & 0.00 & 0.21 & 0.00 & 0.06 \\
\hline 12 & 0.06 & 0.05 & 0.14 & 0.00 & 0.00 & 0.00 & 0.00 & 0.33 & 0.00 & 0.01 & 0.00 & 0.00 \\
\hline 13 & 0.00 & 0.00 & 0.00 & 0.00 & 0.98 & 0.34 & 0.40 & 0.36 & 0.00 & 0.00 & 0.00 & 0.00 \\
\hline 14 & 0.00 & 0.01 & 0.49 & 0.00 & 0.00 & 0.60 & 0.00 & 0.00 & 0.00 & 0.00 & 1.23 & 0.35 \\
\hline 15 & 0.00 & 0.03 & 0.42 & 0.95 & 0.00 & 0.08 & 0.32 & 0.00 & 0.54 & 0.02 & 0.17 & 0.14 \\
\hline 16 & 0.00 & 0.66 & 0.03 & 0.04 & 0.00 & 0.00 & 0.00 & 0.00 & 0.05 & 0.11 & 0.02 & 0.00 \\
\hline 17 & 0.00 & 0.00 & 0.30 & 0.00 & 0.00 & 0.00 & 0.44 & 0.78 & 0.00 & 0.02 & 0.32 & 0.00 \\
\hline 18 & 0.00 & 0.00 & 0.00 & 0.00 & 0.73 & 0.15 & 0.00 & 0.28 & 0.00 & 0.00 & 0.00 & 0.01 \\
\hline 19 & 0.05 & 0.00 & 0.03 & 0.00 & 0.50 & 0.05 & 0.09 & 0.00 & 0.00 & 0.00 & 0.00 & 0.00 \\
\hline 20 & 0.06 & 0.02 & 0.11 & 0.92 & 0.00 & 0.00 & 0.00 & 0.02 & 0.00 & 0.00 & 0.00 & 0.61 \\
\hline 21 & 0.41 & 1.24 & 0.00 & 0.00 & 0.18 & 0.05 & 0.00 & 0.00 & 0.00 & 0.53 & 0.00 & 0.05 \\
\hline 22 & 0.00 & 0.00 & 0.11 & 0.00 & 0.00 & $0.00(e)$ & 0.00 & 0.00 & 0.00 & 0.00 & 0.00 & 0.00 \\
\hline 23 & 0.00 & 0.00 & 1.84 & 0.00 & 0.00 & $0.00(e)$ & 0.01 & 0.00 & 1.42 & 0.00 & 0.00 & 0.03 \\
\hline 24 & 1.19 & 0.00 & 0.02 & 0.00 & 0.00 & $0.00(e)$ & 0.00 & 0.00 & 0.00 & 0.00 & 0.00 & 0.00 \\
\hline 25 & 0.00 & 0.05 & 0.02 & 0.81 & 0.14 & $0.00(e)$ & 0.00 & 0.00 & 0.30 & 0.00 & 0.00 & 0.02 \\
\hline 26 & 0.00 & 0.38 & 0.67 & 0.16 & 0.05 & $0.00(\mathrm{c})$ & 0.00 & 0.00 & 0.30 & 0.00 & 0.65 & 0.00 \\
\hline 27 & 0.00 & 0.00 & 0.50 & 0.00 & 0.00 & $0.00(e)$ & 0.01 & 0.00 & 0.57 & 0.00 & 0.40 & 0.00 \\
\hline 28 & 0.00 & 0.00 & 0.00 & 0.00 & 0.00 & $0.00(c)$ & 0.00 & 0.00 & 0.00 & 0.00 & 0.00 & 0.86 \\
\hline 29 & 0.00 & & 0.00 & 0.00 & 0.00 & $0.13(e)$ & 0.00 & 0.00 & 0.00 & 0.31 & 0.00 & 0.04 \\
\hline 30 & 0.00 & & 0.00 & 0.00 & 0.26 & 1.13 & 0.00 & 0.00 & 0.00 & 0.46 & 0.00 & 0.00 \\
\hline 31 & 0.00 & & 0.99 & & 0.67 & & 0.00 & 0.00 & & 0.05 & & 0.00 \\
\hline TOTAL & 4.14 & 3.10 & 6.87 & 4.47 & 4.10 & 256 & 1.29 & 4.61 & 4.33 & 237 & 3.66 & 7.92 \\
\hline MEAN & 0.13 & 0.11 & 0.22 & 0.15 & 0.13 & 0.09 & 0.04 & 0.15 & 0.14 & 0.08 & 0.12 & 0.26 \\
\hline MAX & 1.19 & 1.24 & 1.84 & 0.95 & 0.98 & 1.13 & 0.44 & 1.57 & 1.42 & 0.53 & 1.23 & 4.53 \\
\hline
\end{tabular}

(e) - Data from station otber tha ETF 
Table A.3. Daily precipitation totals at the SWSA 7 (SW7) raingage for the period January-December 1993 (units=in)

\begin{tabular}{|c|c|c|c|c|c|c|c|c|c|c|c|c|}
\hline DAY & JAN & FEB & MAR & APR & MAY & JUN & IUL & AUG & SEP & OCT & NOV & DEC \\
\hline 1 & 0.00 & 0.00 & 0.00 & 0.08 & 0.00 & 0.00 & 0.00 & 0.00 & 0.00 & 0.00 & 0.00 & 0.00 \\
\hline 2 & 0.00 & 0.00 & 0.19 & 0.05 & 0.00 & 0.00 & 0.00 & 0.01 & 0.02 & 0.20 & 0.00 & 0.00 \\
\hline 3 & 0.00 & 0.00 & 0.56 & 0.00 & 0.01 & 0.00 & 0.00 & 0.00 & 1.02 & 0.00 & 0.00 & 0.24 \\
\hline 4 & 0.57 & 0.00 & 0.31 & 0.03 & 0.45 & 0.00 & 0.00 & 0.75 & 0.03 & 0.00 & 0.37 & 4.27 \\
\hline 5 & 0.17 & 0.00 & 0.00 & 0.45 & 0.00 & 0.00 & 0.00 & 0.03 & 0.00 & 0.00 & 0.48 & 0.02 \\
\hline 6 & 0.00 & 0.00 & 0.00 & 0.00 & 0.00 & 0.00 & 0.00 & 1.47 & 0.00 & 0.00 & 0.00 & 0.00 \\
\hline 7 & 0.31 & 0.00 & 0.04 & 0.00 & 0.00 & 0.00 & 0.00 & 0.00 & 0.00 & 0.00 & 0.00 & 0.00 \\
\hline 8 & 0.38 & 0.00 & 0.02 & $0 . \dot{00}$ & 0.00 & 0.00 & 0.00 & 0.00 & 0.00 & 0.00 & 0.00 & 0.00 \\
\hline 9 & 0.00 & 0.00 & 0.00 & 0.82 & 0.00 & 0.00 & 0.01 & 0.00 & 0.00 & 0.35 & 0.00 & 0.16 \\
\hline 10 & 0.04 & 0.00 & 0.02 & 0.00 & 0.00 & 0.00 & 0.00 & 0.00 & 0.00 & 0.00 & 0.00 & 0.73 \\
\hline 11 & 0.73 & 0.63 & 0.00 & 0.00 & 0.00 & 0.00 & 0.00 & 0.19 & 0.00 & 0.21 & 0.00 & 0.00 \\
\hline 12 & 0.04 & 0.05 & 0.27 & 0.00 & 0.00 & 0.00 & 0.00 & 0.26 & 0.00 & 0.00 & 0.00 & 0.00 \\
\hline 13 & 0.00 & 0.00 & 0.79 & 0.00 & 0.20 & 0.33 & 0.16 & 0.28 & 0.00 & 0.00 & 0.00 & 0.00 \\
\hline 14 & 0.00 & 0.00 & 0.24 & 0.00 & 0.00 & 0.92 & 0.00 & 0.00 & 0.00 & 0.00 & 0.96 & 0.33 \\
\hline 15 & 0.00 & 0.03 & 0.00 & 0.63 & 0.00 & 0.16 & 0.47 & 0.00 & 0.50 & 0.02 & 0.26 & 0.11 \\
\hline 16 & 0.00 & 0.60 & 0.01 & 0.03 & 0.02 & 0.00 & 0.02 & 0.00 & 0.06 & 0.10 & 0.02 & 0.00 \\
\hline 17 & 0.00 & 0.00 & 0.28 & 0.00 & 0.00 & 0.00 & 0.95 & 0.42 & 0.00 & 0.05 & 0.24 & 0.00 \\
\hline 18 & 0.00 & 0.00 & 0.00 & 0.00 & 0.68 & 0.05 & 0.00 & 0.07 & 0.00 & 0.00 & 0.00 & 0.01 \\
\hline 19 & 0.07 & 0.00 & 0.00 & 0.00 & 0.42 & 0.26 & 0.00 & 0.00 & 0.00 & 0.00 & 0.00 & 0.00 \\
\hline 20 & 0.04 & 0.03 & 0.09 & 0.87 & 0.05 & 0.00 & 0.00 & 0.06 & 0.00 & 0.00 & 0.00 & 0.59 \\
\hline 21 & 0.38 & 1.30 & 0.00 & 0.00 & 0.18 & 0.05 & 0.00 & 0.00 & 0.00 & 0.58 & 0.00 & 0.05 \\
\hline 22 & 0.00 & 0.00 & 0.08 & 0.00 & 0.00 & 0.00 & 0.00 & 0.00 & 0.00 & 0.00 & 0.00 & 0.00 \\
\hline 23 & 0.00 & 0.00 & 1.89 & 0.00 & 0.00 & 0.00 & 0.00 & 0.00 & 1.02 & 0.00 & 0.00 & 0.02 \\
\hline 24 & 1.06 & 0.00 & 0.00 & 0.00 & 0.00 & 0.00 & 0.00 & 0.00 & 0.00 & 0.00 & 0.00 & 0.00 \\
\hline 25 & 0.00 & 0.41 & 0.02 & 0.79 & 0.14 & 0.00 & 0.00 & 0.00 & 0.35 & 0.00 & 0.00 & 0.02 \\
\hline 26 & 0.00 & 0.14 & 0.62 & 0.13 & 0.03 & 0.00 & 0.00 & 0.00 & 0.26 & 0.00 & 0.66 & 0.00 \\
\hline 27 & 0.00 & 0.00 & 0.46 & 0.00 & 0.00 & 0.00 & 0.15 & 0.00 & 0.54 & 0.00 & 0.43 & 0.00 \\
\hline 28 & 0.00 & 0.00 & 0.00 & 0.00 & 0.00 & 0.00 & 0.00 & 0.00 & 0.00 & 0.00 & 0.00 & 0.80 \\
\hline 29 & 0.00 & & 0.00 & 0.00 & 0.09 & 0.00 & 0.00 & 0.00 & 0.00 & 0.29 & 0.00 & 0.03 \\
\hline 30 & 0.00 & & 0.00 & 0.00 & 0.12 & 0.66 & 0.00 & 0.00 & 0.00 & 0.43 & 0.00 & 0.00 \\
\hline 31 & 0.00 & & 0.86 & & 0.62 & & 0.00 & 0.00 & & 0.08 & & 0.00 \\
\hline TOTAL & 3.79 & 3.19 & 6.75 & 3.88 & 3.01 & 243 & 1.76 & 3.54 & 3.80 & 231 & 3.42 & 7.38 \\
\hline MEAN & 0.12 & 0.11 & 0.22 & 0.13 & 0.10 & 0.08 & 0.06 & 0.11 & 0.13 & 0.07 & 0.11 & 0.24 \\
\hline MAX & 1.06 & 1.30 & 1.89 & 0.87 & 0.68 & 0.92 & 0.95 & 1.47 & 1.02 & 0.58 & 0.96 & 4.27 \\
\hline
\end{tabular}


Table A.4. Daily precipitation totals for the 49-Trench (49T) raingage for the period January-December 1993 (units=in)

\begin{tabular}{|c|c|c|c|c|c|c|c|c|c|c|c|c|}
\hline DAY & SAN & FEB & MAR & APR & MAY & JUN & JUL & AUG & SEP & OCT & NOV & DEC \\
\hline 1 & 0.00 & 0.00 & 0.00 & 0.07 & 0.00 & $0.00(e)$ & 0.00 & 0.00 & 0.00 & 0.00 & $0.00(e)$ & 0.00 \\
\hline 2 & 0.00 & 0.00 & 0.22 & 0.04 & 0.00 & $0.00(e)$ & 0.00 & 0.07 & 0.06 & 0.25 & 0.00 & 0.00 \\
\hline 3 & 0.00 & 0.00 & 0.62 & 0.00 & 0.03 & $0.00(\mathrm{e})$ & 0.00 & 0.00 & 1.08 & 0.00 & 0.00 & 0.22 \\
\hline 4 & 0.56 & 0.00 & 0.26 & 0.04 & 0.48 & $0.00(\mathrm{e})$ & 0.00 & 0.93 & 0.00 & 0.00 & 0.40 & 4.31 \\
\hline 5 & 0.21 & 0.00 & 0.01 & 0.46 & 0.00 & $0.00(e)$ & 0.00 & 0.00 & 0.00 & 0.00 & 0.47 & 0.03 \\
\hline 6 & 0.00 & 0.00 & 0.00 & 0.00 & 0.00 & $0.00(e)$ & 0.00 & 1.57 & 0.00 & 0.00 & 0.00 & 0.00 \\
\hline 7 & 0.33 & 0.00 & 0.03 & 0.00 & 0.00 & $0.00(e)$ & 0.00 & 0.00 & 0.00 & 0.00 & 0.00 & 0.00 \\
\hline 8 & 0.34 & 0.00 & 0.01 & 0.00 & 0.02 & $0.00(c)$ & 0.00 & 0.00 & 0.00 & 0.00 & 0.00 & 0.00 \\
\hline 9 & 0.00 & 0.00 & 0.00 & 0.90 & 0.00 & 0.00 & 0.04 & 0.00 & 0.00 & 0.34 & 0.00 & 0.19 \\
\hline 10 & 0.03 & 0.00 & 0.00 & 0.00 & 0.00 & 0.02 & 0.00 & 0.00 & 0.00 & 0.00 & 0.00 & 0.67 \\
\hline 11 & 0.74 & 0.64 & 0.00 & 0.00 & 0.00 & 0.00 & $0.00(e)$ & 0.00 & 0.00 & 0.22 & 0.00 & 0.06 \\
\hline 12 & 0.05 & 0.04 & 0.16 & $0.00(e)$ & 0.00 & 0.00 & $0.00(e)$ & 0.39 & 0.00 & 0.01 & 0.00 & 0.00 \\
\hline 13 & 0.00 & 0.00 & 0.00 & $0.00(e)$ & 0.87 & 0.33 & $0.40(e)$ & 0.34 & 0.00 & 0.00 & 0.00 & 0.00 \\
\hline 14 & 0.00 & 0.01 & 0.63 & $0.00(e)$ & 0.00 & 0.68 & 0.00 & 0.00 & 0.00 & 0.00 & 1.09 & 0.32 \\
\hline 15 & 0.00 & 0.02 & 0.00 & $0.95(\mathrm{e})$ & 0.00 & 0.06 & 0.30 & 0.00 & 0.52 & 0.03 & 0.26 & 0.13 \\
\hline 16 & 0.00 & 0.62 & 0.03 & $0.04(e)$ & 0.00 & 0.00 & 0.00 & 0.00 & 0.05 & 0.09 & 0.01 & 0.00 \\
\hline 17 & 0.00 & 0.00 & 0.29 & $0.00(e)$ & 0.00 & 0.00 & 0.46 & 0.98 & 0.00 & 0.04 & 0.32 & 0.00 \\
\hline 18 & 0.00 & 0.00 & 0.00 & $0.00(e)$ & 0.58 & 0.15 & 0.00 & 0.10 & 0.00 & 0.00 & 0.00 & 0.02 \\
\hline 19 & 0.07 & 0.00 & 0.04 & $0.00(c)$ & 0.49 & 0.05 & 0.09 & 0.00 & 0.00 & 0.00 & 0.00 & 0.00 \\
\hline 20 & 0.06 & 0.02 & 0.10 & $0.92(e)$ & 0.00 & 0.00 & 0.00 & 0.03 & 0.00 & 0.00 & 0.00 & 0.56 \\
\hline 21 & 0.38 & 1.18 & 0.00 & 0.00 & 0.18 & 0.06 & 0.00 & 0.00 & 0.00 & 0.53 & 0.00 & 0.06 \\
\hline 22 & 0.00 & 0.00 & 0.09 & 0.00 & 0.00 & 0.00 & 0.00 & 0.00 & 0.00 & 0.00 & 0.00 & 0.01 \\
\hline 23 & 0.00 & 0.00 & 1.83 & 0.00 & 0.00 & 0.00 & 0.01 & 0.00 & 1.33 & 0.00 & 0.00 & 0.03 \\
\hline 24 & 1.10 & 0.00 & 0.00 & 0.00 & 0.00 & 0.00 & 0.00 & 0.00 & 0.00 & 0.00 & 0.00 & 0.00 \\
\hline 25 & 0.00 & 0.10 & 0.02 & 0.79 & 0.12 & 0.00 & 0.00 & 0.00 & 0.33 & 0.00 & 0.00 & 0.01 \\
\hline 26 & 0.00 & 0.38 & 0.63 & 0.11 & 0.05 & 0.00 & 0.00 & 0.00 & 0.31 & 0.00 & 0.61 & 0.00 \\
\hline 27 & 0.00 & 0.00 & 0.45 & 0.00 & 0.00 & 0.00 & 0.02 & 0.00 & 0.52 & 0.00 & 0.40 & 0.00 \\
\hline 28 & 0.00 & 0.00 & 0.00 & 0.00 & 0.00 & 0.00 & 0.00 & 0.00 & 0.00 & 0.00 & 0.00 & 0.78 \\
\hline 29 & 0.00 & & 0.00 & 0.00 & 0.01 & 0.13 & 0.00 & 0.00 & 0.00 & $0.31(c)$ & 0.00 & 0.04 \\
\hline 30 & 0.00 & & 0.00 & 0.00 & 0.20 & 0.99 & 0.00 & 0.00 & 0.00 & $0.46(\mathrm{e})$ & 0.00 & 0.00 \\
\hline 31 & 0.00 & & 0.92 & & 0.70 & & 0.00 & 0.00 & & $0.05(\mathrm{e})$ & & 0.00 \\
\hline TOTAL & 3.87 & 3.01 & 6.34 & 4.32 & 3.73 & 247 & 1.32 & 4.67 & 4.20 & 233 & 3.56 & 7.44 \\
\hline MEAN & 0.13 & 0.11 & 0.21 & 0.14 & 0.12 & 0.08 & 0.04 & 0.15 & 0.14 & 0.08 & 0.12 & 0.24 \\
\hline MAX & 1.10 & 1.18 & 1.83 & 0.95 & 0.87 & 0.99 & 0.46 & 1.57 & 1.33 & 0.53 & 1.09 & 4.31 \\
\hline
\end{tabular}

(e) - Dats from station other than 49T 
Table A.5. Daily precipitation totals at the SWSA 4 (SW4) raingage for the period January-December 1993

(units=in)

\begin{tabular}{|c|c|c|c|c|c|c|c|c|c|c|c|c|}
\hline DAY & JAN & FEB & MAR & APR & MAY & IUN & JUL & AUG & SEP & OCT & NOV & DEC \\
\hline 1 & 0.00 & 0.00 & 0.00 & $0.11(e)$ & 0.00 & 0.00 & 0.00 & 0.00 & 0.00 & 0.00 & 0.00 & 0.00 \\
\hline 2 & 0.00 & 0.00 & 0.23 & $0.03(e)$ & 0.00 & 0.00 & 0.00 & 0.07 & 0.09 & 0.29 & 0.00 & 0.00 \\
\hline 3 & 0.00 & 0.00 & 0.57 & $0.00(e)$ & 0.03 & 0.00 & 0.00 & 0.00 & 1.22 & 0.00 & 0.00 & 0.26 \\
\hline 4 & 0.56 & 0.00 & 0.27 & $0.05(e)$ & 0.51 & 0.00 & 0.00 & 1.03 & 0.00 & 0.00 & 0.35 & 4.27 \\
\hline 5 & 0.19 & 0.00 & 0.00 & $0.47(e)$ & 0.00 & 0.00 & 0.00 & 0.00 & 0.00 & 0.00 & 0.49 & 0.02 \\
\hline 6 & 0.00 & 0.00 & 0.00 & $0.00(c)$ & 0.00 & 0.00 & 0.00 & 1.66 & 0.00 & 0.00 & 0.00 & 0.00 \\
\hline 7 & 0.32 & 0.00 & 0.05 & $0.00(e)$ & 0.00 & 0.00 & 0.00 & 0.00 & 0.00 & 0.00 & 0.00 & 0.00 \\
\hline 8 & 0.33 & 0.00 & 0.02 & 0.00 & 0.02 & 0.00 & 0.00 & 0.00 & 0.00 & 0.00 & 0.00 & 0.00 \\
\hline 9 & 0.00 & 0.00 & 0.00 & 0.91 & 0.00 & 0.00 & 0.04 & 0.00 & 0.00 & 0.35 & 0.00 & 0.20 \\
\hline 10 & 0.04 & 0.00 & 0.01 & 0.00 & 0.00 & 0.00 & 0.00 & 0.00 & 0.00 & 0.00 & 0.00 & 0.68 \\
\hline 11 & 0.72 & 0.63 & 0.00 & 0.00 & 0.00 & 0.00 & 0.00 & 0.36 & 0.00 & 0.18 & 0.00 & 0.01 \\
\hline 12 & 0.06 & 0.06 & 0.14 & 0.00 & 0.00 & 0.00 & 0.00 & 0.53 & 0.00 & 0.00 & 0.00 & 0.00 \\
\hline 13 & 0.01 & 0.00 & 0.00 & 0.00 & 0.58 & 0.31 & 0.25 & 0.28 & 0.00 & 0.00 & 0.00 & 0.00 \\
\hline 14 & 0.00 & 0.00 & 0.19 & 0.00 & 0.00 & 0.75 & 0.00 & 0.00 & 0.00 & 0.00 & 1.10 & 0.33 \\
\hline 15 & 0.00 & 0.03 & 0.51 & 0.79 & 0.00 & 0.06 & 0.46 & 0.00 & 0.45 & 0.02 & 0.26 & 0.11 \\
\hline 16 & 0.00 & 0.63 & 0.02 & 0.02 & 0.00 & 0.00 & 0.00 & 0.00 & 0.08 & 0.12 & 0.02 & $0.00(e)$ \\
\hline 17 & 0.00 & 0.00 & 0.28 & 0.00 & 0.00 & 0.00 & 0.68 & 0.51 & 0.00 & 0.05 & 0.29 & $0.00(e)$ \\
\hline 18 & 0.00 & 0.00 & 0.00 & 0.00 & 0.56 & 0.11 & 0.00 & 0.29 & 0.00 & $0.00(\mathrm{e})$ & 0.00 & $0.01(\mathrm{c})$ \\
\hline 19 & 0.04 & 0.00 & 0.00 & 0.00 & 0.51 & 0.15 & 0.01 & 0.00 & 0.00 & $0.00(c)$ & 0.00 & $0.00(e)$ \\
\hline 20 & 0.05 & 0.02 & 0.09 & 0.80 & 0.00 & 0.00 & 0.00 & 0.08 & 0.00 & $0.00(e)$ & 0.00 & $0.57(\mathrm{e})$ \\
\hline 21 & 0.39 & 1.25 & 0.00 & 0.00 & 0.30 & 0.02 & 0.00 & 0.00 & 0.00 & 0.67 & 0.00 & $0.06(\mathrm{e})$ \\
\hline 22 & 0.00 & 0.00 & 0.11 & 0.00 & 0.00 & 0.00 & 0.00 & 0.00 & 0.00 & 0.00 & 0.00 & $0.00(\mathrm{c})$ \\
\hline 23 & 0.00 & 0.00 & 206 & 0.00 & 0.00 & 0.00 & 0.00 & 0.00 & 1.23 & 0.00 & 0.00 & 0.02 \\
\hline 24 & 1.05 & 0.00 & 0.00 & 0.00 & 0.00 & 0.00 & 0.00 & 0.00 & 0.00 & 0.00 & 0.00 & 0.00 \\
\hline 25 & 0.00 & 0.00 & 0.01 & 0.74 & 0.12 & 0.00 & 0.00 & 0.00 & 0.37 & 0.00 & 0.00 & 0.03 \\
\hline 26 & 0.00 & 0.41 & 0.56 & 0.19 & 0.05 & 0.02 & 0.00 & 0.00 & 0.35 & 0.00 & 0.60 & 0.00 \\
\hline 27 & 0.00 & 0.00 & 0.44 & 0.00 & 0.00 & 0.00 & 0.01 & 0.00 & 0.56 & 0.00 & 0.42 & 0.00 \\
\hline 28 & 0.00 & 0.00 & 0.00 & 0.00 & 0.00 & 0.00 & 0.00 & 0.00 & 0.00 & 0.00 & 0.00 & 0.82 \\
\hline 29 & 0.00 & & 0.00 & 0.00 & 0.04 & 0.13 & 0.00 & 0.00 & 0.00 & 0.25 & 0.00 & 0.03 \\
\hline 30 & 0.00 & & 0.00 & 0.00 & 0.14 & 1.07 & 0.00 & 0.00 & 0.00 & 0.44 & 0.00 & 0.00 \\
\hline 31 & 0.00 & & $0.92(e)$ & & 0.67 & & 0.00 & 0.00 & & 0.06 & & 0.00 \\
\hline TOTAL & 3.76 & 3.03 & 6.48 & 4.11 & 3.53 & 262 & 1.46 & 4.81 & 4.35 & 243 & 3.53 & 7.42 \\
\hline MEAN & 0.12 & 0.11 & 0.21 & 0.14 & 0.11 & 0.09 & 0.05 & 0.16 & 0.15 & 0.08 & 0.12 & 0.24 \\
\hline MAX & 1.05 & 1.25 & 206 & 0.91 & 0.67 & 1.07 & 0.68 & 1.66 & 1.23 & 0.67 & 1.10 & 4.27 \\
\hline
\end{tabular}

(e) - Data from station other than SW4 
Table A6. Daily precipitation totals at the Ish Creek (ISH) raingage for the period January-December 1993

(units=in)

\begin{tabular}{|c|c|c|c|c|c|c|c|c|c|c|c|c|}
\hline DAY & JAN & FEB & MAR & APR & MAY & JUN & JUL & AUG & SEP & OCT & NOV & DEC \\
\hline 1 & 0.00 & 0.00 & 0.00 & 0.09 & 0.00 & $0.00(e)$ & $0.00(e)$ & 0.00 & 0.00 & 0.00 & 0.00 & $0.00(c)$ \\
\hline 2 & 0.00 & 0.00 & 0.21 & 0.06 & 0.00 & $0.00(e)$ & $0.00(e)$ & 0.17 & 0.12 & 0.19 & 0.00 & $0.00(e)$ \\
\hline 3 & 0.00 & 0.00 & 0.58 & 0.00 & 0.02 & $0.00(c)$ & $0.00(\mathrm{e})$ & 0.00 & 1.62 & 0.00 & 0.00 & $0.27(\mathrm{e})$ \\
\hline 4 & 0.70 & 0.00 & 0.29 & 0.05 & 0.51 & $0.00(e)$ & $0.00(e)$ & 1.01 & 0.00 & 0.00 & 0.38 & $4.53(\mathrm{c})$ \\
\hline 5 & 0.20 & 0.00 & 0.03 & 0.48 & 0.00 & $0.00(\mathrm{c})$ & $0.00(e)$ & 0.03 & 0.00 & 0.00 & 0.46 & $0.04(\mathrm{e})$ \\
\hline 6 & 0.00 & 0.00 & 0.00 & 0.01 & 0.00 & $0.00(e)$ & $0.00(e)$ & 1.46 & 0.00 & 0.00 & 0.00 & $0.00(e)$ \\
\hline 7 & 0.33 & 0.00 & 0.05 & 0.00 & 0.00 & $0.00(e)$ & $0.00(e)$ & 0.00 & 0.00 & 0.00 & 0.00 & $0.00(e)$ \\
\hline 8 & 0.32 & 0.00 & 0.01 & 0.00 & 0.05 & $0.00(e)$ & $0.00(e)$ & 0.00 & 0.00 & 0.00 & 0.00 & $0.00(\mathrm{e})$ \\
\hline 9 & 0.00 & 0.00 & 0.00 & 0.90 & 0.00 & $0.00(c)$ & $0.02(e)$ & 0.00 & 0.00 & 0.32 & 0.00 & $0.20(e)$ \\
\hline 10 & 0.03 & 0.00 & 0.00 & 0.01 & 0.00 & 0.00 & $0.00(c)$ & 0.00 & 0.00 & 0.00 & 0.00 & $0.71(c)$ \\
\hline 11 & 0.71 & 0.66 & 0.00 & 0.00 & 0.00 & 0.00 & $0.00(c)$ & 0.15 & 0.00 & 0.18 & 0.00 & $0.06(e)$ \\
\hline 12 & 0.06 & 0.05 & 0.09 & 0.00 & 0.00 & 0.00 & $0.00(\mathrm{e})$ & 0.16 & 0.00 & 0.00 & 0.00 & $0.00(c)$ \\
\hline 13 & 0.00 & 0.00 & 0.00 & 0.00 & 0.56 & 0.64 & $0.40(e)$ & 0.25 & 0.00 & 0.00 & 0.00 & $0.00(c)$ \\
\hline 14 & 0.00 & 0.03 & 0.44 & 0.00 & 0.00 & 0.46 & $0.00(e)$ & 0.00 & 0.00 & 0.00 & 1.07 & $0.35(c)$ \\
\hline 15 & 0.00 & 0.03 & 0.97 & 0.73 & 0.00 & 0.06 & .31 & 0.00 & 0.39 & 0.02 & 0.23 & $0.14(e)$ \\
\hline 16 & 0.00 & 0.68 & 0.02 & 0.04 & 0.03 & 0.00 & 0.04 & 0.00 & 0.06 & 0.17 & 0.03 & $0.00(c)$ \\
\hline 17 & 0.00 & 0.00 & 0.31 & 0.00 & 0.00 & 0.00 & 0.63 & 0.38 & 0.00 & 0.05 & 0.34 & $0.00(e)$ \\
\hline 18 & 0.00 & 0.00 & 0.00 & 0.00 & 0.41 & 0.26 & 0.00 & 0.25 & 0.00 & 0.00 & 0.00 & $0.01(c)$ \\
\hline 19 & 0.06 & 0.00 & 0.04 & 0.00 & 0.39 & 0.05 & 0.13 & 0.00 & 0.00 & 0.00 & 0.00 & $0.00(e)$ \\
\hline 20 & 0.06 & 0.02 & 0.10 & $0.92(\mathrm{e})$ & 0.00 & 0.00 & 0.00 & 0.09 & 0.00 & 0.00 & 0.00 & $0.61(e)$ \\
\hline 21 & 0.39 & 1.43 & 0.01 & $0.00(e)$ & 0.12 & 0.03 & 0.00 & 0.00 & 0.00 & 0.59 & 0.00 & $0.05(e)$ \\
\hline 22 & 0.00 & 0.00 & 0.15 & $0.00(e)$ & 0.00 & 0.00 & 0.00 & 0.00 & 0.00 & 0.00 & 0.00 & $0.00(\mathrm{e})$ \\
\hline 23 & 0.00 & 0.00 & 237 & $0.00(\mathrm{c})$ & 0.00 & 0.00 & 0.02 & 0.00 & 1.24 & 0.00 & 0.00 & 0.01 \\
\hline 24 & 1.05 & 0.00 & 0.01 & $0.00(e)$ & 0.00 & 0.00 & 0.00 & 0.00 & 0.00 & 0.00 & 0.00 & 0.00 \\
\hline 25 & 0.00 & 0.02 & 0.02 & $0.81(\mathrm{c})$ & 0.16 & 0.00 & 0.00 & 0.05 & 0.23 & 0.00 & 0.00 & 0.01 \\
\hline 26 & 0.00 & 0.46 & 0.66 & $0.16(e)$ & 0.06 & 0.00 & 0.00 & 0.00 & 0.28 & 0.00 & 0.55 & 0.00 \\
\hline 27 & 0.00 & 0.00 & 0.42 & $0.00(e)$ & 0.00 & 0.00 & 0.00 & 0.00 & 0.53 & 0.00 & 0.42 & 0.00 \\
\hline 28 & 0.00 & 0.00 & 0.00 & $0.00(c)$ & 0.00 & 0.00 & 0.00 & 0.00 & 0.00 & 0.00 & 0.00 & $0.86(\mathrm{e})$ \\
\hline 29 & 0.00 & & 0.00 & $0.00(c)$ & 0.06 & $0.13(e)$ & 0.00 & 0.00 & 0.00 & 0.24 & 0.00 & $0.04(e)$ \\
\hline 30 & 0.00 & & $0.00(c)$ & $0.00(c)$ & 0.07 & $1.13(c)$ & 0.00 & 0.00 & 0.00 & 0.49 & 0.00 & $0.00(e)$ \\
\hline 31 & 0.00 & & $0.99(c)$ & & 0.67 & & 0.00 & 0.00 & & 0.07 & & $0.00(e)$ \\
\hline TOTAL & 3.91 & 3.38 & 7.77 & 4.26 & 3.11 & 276 & 1.55 & 4.00 & 4.47 & 232 & 3.48 & 7.89 \\
\hline MEAN & 0.13 & 0.12 & 0.25 & 0.14 & 0.10 & 0.09 & 0.05 & 0.13 & 0.15 & 0.07 & 0.12 & 0.25 \\
\hline MAX & 1.05 & 1.43 & 237 & 0.92 & 0.67 & 1.13 & 0.63 & 1.46 & 1.62 & 0.59 & 1.07 & 4.53 \\
\hline
\end{tabular}

(e) - Dath from station other than ISH 
Table A.7 Daily precipitation totals at the Walker Branch Watershed (RG1) raingage for the period January-December 1993

(units=in)

\begin{tabular}{|c|c|c|c|c|c|c|c|c|c|c|c|c|}
\hline DAY & JAN & FEB & MAR & APR & MAY & JUN & JUL & AUG & SEP & OCT & Nov & DEC \\
\hline 1 & 0.00 & 0.00 & 0.00 & 0.10 & 0.00 & 0.00 & 0.00 & 0.00 & 0.00 & 0.00 & 0.02 & 0.00 \\
\hline 2 & 0.00 & 0.00 & 0.18 & 0.09 & 0.00 & 0.00 & 0.00 & 0.01 & 0.04 & 0.11 & 0.00 & 0.00 \\
\hline 3 & 0.00 & 0.00 & 0.57 & 0.00 & 0.01 & 0.00 & $0.00(e)$ & 0.00 & 1.59 & 0.01 & 0.00 & 0.22 \\
\hline 4 & 0.49 & 0.00 & 0.39 & 0.01 & 0.43 & 0.00 & $0.00(e)$ & 0.26 & 0.01 & 0.00 & 0.34 & 4.60 \\
\hline 5 & 0.17 & 0.00 & 0.04 & 0.41 & 0.00 & 0.00 & $0.00(e)$ & 0.00 & 0.00 & 0.00 & 0.51 & 0.02 \\
\hline 6 & 0.00 & 0.00 & 0.00 & 0.00 & 0.00 & 0.00 & $0.00(e)$ & 1.49 & 0.00 & 0.00 & 0.00 & 0.00 \\
\hline 7 & 0.28 & 0.00 & 0.02 & 0.00 & 0.00 & 0.00 & $0.00(\mathrm{c})$ & 0.00 & 0.00 & 0.00 & 0.00 & 0.00 \\
\hline 8 & 0.36 & 0.00 & 0.02 & 0.00 & 0.02 & 0.00 & $0.00(\mathrm{e})$ & 0.00 & 0.00 & 0.00 & 0.00 & 0.00 \\
\hline 9 & 0.00 & 0.00 & 0.00 & 0.80 & 0.00 & 0.00 & $0.00(e)$ & 0.00 & 0.00 & 0.27 & 0.00 & 0.22 \\
\hline 10 & 0.03 & 0.00 & 0.00 & 0.01 & 0.00 & 0.00 & $0.00(e)$ & 0.00 & 0.00 & 0.00 & 0.00 & 0.75 \\
\hline 11 & 0.74 & 0.60 & 0.00 & 0.00 & 0.00 & 0.00 & $0.00(c)$ & 0.12 & 0.00 & 0.15 & 0.00 & 0.00 \\
\hline 12 & 0.05 & 0.10 & 0.18 & 0.00 & 0.00 & 0.00 & $0.00(\mathrm{c})$ & 0.16 & 0.00 & 0.00 & 0.00 & 0.00 \\
\hline 13 & 0.00 & 0.00 & 0.39 & 0.00 & 0.28 & 0.32 & $0.29(\mathrm{c})$ & 0.39 & 0.00 & 0.00 & 0.00 & 0.00 \\
\hline 14 & 0.00 & 0.00 & 0.37 & 0.00 & 0.00 & 0.41 & 0.05 & 0.00 & 0.00 & 0.00 & 0.87 & 0.31 \\
\hline 15 & 0.00 & 0.05 & 0.00 & 0.68 & 0.00 & 0.05 & 0.33 & 0.00 & 0.70 & 0.00 & 0.24 & 0.09 \\
\hline 16 & 0.00 & 0.69 & 0.00 & 0.05 & 0.01 & 0.00 & 0.00 & 0.00 & 0.27 & 0.19 & 0.01 & 0.00 \\
\hline 17 & 0.00 & 0.00 & 0.27 & 0.00 & 0.00 & 0.00 & 0.41 & 0.50 & 0.00 & 0.07 & 0.34 & 0.00 \\
\hline 18 & 0.00 & 0.00 & 0.00 & 0.00 & 0.50 & 0.01 & 0.00 & 0.04 & 0.00 & 0.00 & 0.00 & 0.02 \\
\hline 19 & 0.00 & 0.00 & 0.00 & 0.00 & 0.37 & 0.38 & 0.36 & 0.00 & 0.00 & 0.00 & 0.00 & 0.00 \\
\hline 20 & 0.01 & 0.01 & 0.06 & 0.82 & 0.03 & 0.00 & 0.00 & 0.03 & 0.00 & 0.00 & 0.00 & 0.60 \\
\hline 21 & 0.38 & 1.62 & 0.01 & 0.00 & 0.22 & $0.00(e)$ & 0.00 & 0.00 & 0.00 & 0.48 & 0.00 & 0.03 \\
\hline 22 & 0.00 & 0.00 & 0.07 & 0.00 & 0.00 & $0.00(e)$ & 0.00 & 0.00 & 0.00 & 0.00 & 0.00 & 0.00 \\
\hline 23 & 0.00 & 0.00 & 222 & 0.00 & 0.00 & $0.00(\mathrm{c})$ & 0.00 & 0.00 & 0.93 & 0.00 & 0.00 & 0.03 \\
\hline 24 & 1.00 & 0.00 & 0.00 & 0.00 & 0.00 & 0.00 & 0.00 & 0.00 & 0.00 & 0.00 & 0.00 & 0.00 \\
\hline 25 & 0.00 & 0.30 & 0.00 & 0.70 & 0.09 & 0.00 & 0.01 & 0.00 & 0.30 & 0.00 & 0.00 & 0.03 \\
\hline 26 & 0.00 & 0.16 & 0.52 & 0.16 & 0.02 & 0.00 & 0.00 & 0.00 & 0.45 & 0.00 & 0.63 & 0.00 \\
\hline 27 & 0.00 & 0.00 & 0.52 & 0.00 & 0.00 & 0.00 & 1.05 & 0.00 & 0.48 & 0.00 & 0.46 & 0.00 \\
\hline 28 & 0.00 & 0.00 & 0.00 & 0.00 & 0.00 & $0.00(\mathrm{e})$ & 0.00 & 0.00 & 0.00 & 0.00 & 0.00 & 0.86 \\
\hline 29 & 0.00 & & 0.00 & 0.00 & 0.27 & $0.00(e)$ & 0.00 & 0.00 & 0.00 & 0.25 & 0.00 & 0.04 \\
\hline 30 & 0.00 & & 0.00 & 0.00 & 0.09 & 0.39 & 0.00 & 0.00 & 0.00 & 0.45 & 0.00 & 0.00 \\
\hline 31 & 0.00 & & 0.50 & & 0.61 & & 0.00 & 0.00 & & 0.08 & & 0.00 \\
\hline TOTAL & 3.51 & 3.53 & 6.33 & 3.83 & 295 & 1.56 & 250 & 3.00 & 4.77 & 206 & 3.42 & 7.82 \\
\hline MEAN & 0.11 & 0.13 & 0.20 & 0.13 & 0.10 & 0.05 & 0.08 & 0.10 & 0.16 & 0.07 & 0.11 & 0.25 \\
\hline MAX & 1.00 & 1.62 & 222 & 0.83 & 0.61 & 0.41 & 1.05 & 1.49 & 1.59 & 0.48 & 0.87 & 4.60 \\
\hline
\end{tabular}

(e) - Data from station other than RG1 
Table A.8. Daily precipitation totals at the Walker Branch Watershed (RG3) raingage for the period January-December 1993

(units=in)

\begin{tabular}{|c|c|c|c|c|c|c|c|c|c|c|c|c|}
\hline DAY & JAN & FEB & MAR & APR & MAY & JUN & ЛU & AUG & SEP & OCr & Nov & DEC \\
\hline 1 & $0.00(e)$ & $0.00(e)$ & 0.00 & 0.08 & 0.00 & 0.00 & 0.00 & 0.00 & 0.00 & 0.00 & 0.02 & 0.00 \\
\hline 2 & $0.00(\mathrm{e})$ & $0.00(e)$ & 0.18 & 0.10 & 0.00 & 0.00 & 0.00 & 0.03 & 0.03 & 0.14 & 0.00 & 0.00 \\
\hline 3 & $0.00(e)$ & $0.00(e)$ & 0.58 & 0.00 & 0.01 & 0.00 & 0.00 & 0.00 & 1.56 & 0.01 & 0.00 & 0.24 \\
\hline 4 & $0.49(e)$ & $0.00(e)$ & 0.30 & 0.02 & 0.44 & 0.00 & 0.00 & 0.30 & 0.02 & 0.00 & 0.36 & 4.59 \\
\hline 5 & $0.17(\mathrm{e})$ & $0.00(e)$ & 0.02 & 0.40 & 0.00 & 0.00 & 0.00 & 0.00 & 0.00 & 0.00 & 0.53 & 0.03 \\
\hline 6 & 0.00 & $0.00(\mathrm{e})$ & 0.00 & 0.00 & 0.00 & 0.00 & 0.00 & 1.47 & 0.00 & 0.00 & 0.00 & 0.00 \\
\hline 7 & 0.30 & $0.00(c)$ & 0.03 & 0.00 & 0.00 & 0.00 & 0.00 & 0.00 & 0.00 & 0.00 & 0.00 & 0.00 \\
\hline 8 & 0.34 & $0.00(e)$ & 0.01 & 0.00 & 0.04 & 0.00 & 0.00 & 0.00 & 0.00 & 0.00 & 0.00 & 0.00 \\
\hline 9 & 0.00 & $0.00(e)$ & 0.00 & 0.84 & 0.00 & 0.00 & 0.00 & 0.00 & 0.00 & 0.27 & 0.00 & 0.21 \\
\hline 10 & 0.03 & 0.00 & 0.00 & 0.02 & 0.00 & 0.00 & 0.00 & 0.00 & 0.00 & 0.00 & 0.00 & 0.73 \\
\hline 11 & 0.72 & 0.60 & 0.00 & 0.00 & 0.00 & 0.00 & 0.00 & 0.05 & 0.00 & 0.17 & 0.00 & 0.00 \\
\hline 12 & 0.05 & 0.09 & 0.20 & 0.00 & 0.00 & 0.00 & 0.00 & 0.22 & 0.00 & 0.00 & 0.00 & 0.00 \\
\hline 13 & 0.00 & 0.02 & 0.66 & 0.00 & 0.31 & 0.33 & 0.29 & 0.35 & 0.00 & 0.00 & 0.00 & 0.00 \\
\hline 14 & 0.00 & 0.00 & 0.10 & 0.00 & 0.00 & 0.39 & 0.16 & 0.00 & 0.00 & 0.00 & 0.80 & 0.28 \\
\hline 15 & 0.00 & 0.05 & 0.00 & 0.70 & 0.00 & 0.05 & 0.13 & 0.00 & 0.68 & 0.00 & 0.24 & 0.09 \\
\hline 16 & 0.00 & 0.67 & 0.00 & 0.04 & 0.02 & 0.00 & 0.00 & 0.00 & 0.33 & 0.22 & 0.02 & 0.00 \\
\hline 17 & 0.00 & 0.00 & 0.25 & 0.00 & 0.00 & 0.00 & 0.28 & 0.40 & 0.00 & 0.09 & 0.36 & 0.00 \\
\hline 18 & 0.00 & 0.00 & 0.00 & 0.00 & 0.66 & 0.02 & 0.00 & 0.06 & 0.00 & 0.00 & 0.00 & 0.01 \\
\hline 19 & 0.04 & 0.00 & 0.00 & 0.00 & 0.27 & 0.42 & 0.46 & 0.00 & 0.00 & 0.00 & 0.00 & 0.00 \\
\hline 20 & 0.03 & 0.02 & 0.07 & 0.81 & 0.07 & 0.00 & 0.00 & 0.01 & 0.00 & 0.00 & 0.00 & 0.59 \\
\hline 21 & 0.36 & 1.72 & 0.00 & 0.00 & 0.20 & 0.00 & 0.00 & 0.00 & 0.00 & 0.49 & 0.00 & 0.03 \\
\hline 22 & 0.00 & 0.00 & 0.08 & 0.00 & 0.00 & 0.00 & 0.00 & 0.00 & 0.00 & 0.00 & 0.00 & 0.00 \\
\hline 23 & 0.00 & 0.00 & 229 & 0.00 & 0.00 & 0.00 & 0.00 & 0.00 & 0.89 & 0.00 & 0.00 & 0.02 \\
\hline 24 & 1.03 & 0.00 & 0.00 & 0.00 & 0.00 & 0.00 & 0.00 & 0.00 & 0.00 & 0.00 & 0.00 & 0.00 \\
\hline 25 & 0.00 & 0.31 & 0.00 & 0.75 & 0.12 & 0.00 & 0.02 & 0.13 & 0.33 & 0.00 & 0.00 & 0.02 \\
\hline 26 & $0.00(e)$ & 0.14 & 0.49 & 0.10 & 0.01 & 0.00 & 0.00 & 0.00 & 0.55 & 0.00 & 0.62 & 0.00 \\
\hline 27 & $0.00(e)$ & 0.00 & 0.51 & 0.00 & 0.00 & 0.00 & 1.15 & 0.00 & 0.48 & 0.00 & 0.44 & 0.00 \\
\hline 28 & $0.00(e)$ & 0.00 & 0.00 & 0.00 & 0.00 & 0.00 & 0.00 & 0.00 & 0.00 & 0.00 & 0.00 & 0.87 \\
\hline 29 & $0.00(\mathrm{e})$ & & 0.00 & 0.00 & 0.12 & 0.00 & 0.00 & 0.00 & 0.00 & 0.26 & 0.00 & 0.03 \\
\hline 30 & $0.00(e)$ & & 0.00 & 0.00 & 0.15 & 0.44 & 0.00 & 0.00 & 0.00 & 0.44 & 0.00 & 0.00 \\
\hline 31 & $0.00(\mathrm{e})$ & & 0.54 & & 0.58 & & 0.00 & 0.00 & & 0.07 & & 0.00 \\
\hline TOTAL & 3.56 & 3.62 & 6.31 & 3.86 & 3.00 & 1.65 & 249 & 3.02 & 4.87 & 216 & 3.39 & 7.74 \\
\hline MEAN & 0.12 & 0.13 & 0.20 & 0.13 & 0.10 & 0.06 & 0.08 & 0.10 & 0.16 & 0.07 & 0.11 & 0.25 \\
\hline MAX & 1.03 & 1.72 & 229 & 0.84 & 0.66 & 0.44 & 1.15 & 1.47 & 1.56 & 0.49 & 0.80 & 4.59 \\
\hline
\end{tabular}

(c) - Data from station otber than RG3 
Table A.9. Daily precipitation totals at the Bear Creek Burial Ground (BUR) raingage for the period January-December 1993

(units=in)

\begin{tabular}{|c|c|c|c|c|c|c|c|c|c|c|c|c|}
\hline DAY & JAN & FEB & MAR & APR & MAY & JUN & JU. & AUG & SEP & OCT & NOV & DEC \\
\hline 1 & 0.00 & 0.00 & 0.00 & 0.12 & 0.00 & 0.00 & 0.00 & 0.00 & 0.00 & 0.00 & $0.02(e)$ & 0.00 \\
\hline 2 & 0.00 & 0.00 & 0.21 & 0.06 & 0.00 & 0.00 & 0.00 & 0.05 & 0.09 & 0.22 & $0.00(e)$ & 0.00 \\
\hline 3 & 0.00 & 0.00 & 0.61 & 0.00 & 0.00 & 0.00 & 0.00 & 0.00 & 1.64 & 0.01 & $0.00(e)$ & 0.25 \\
\hline 4 & 0.63 & 0.00 & 0.38 & 0.05 & 0.46 & 0.00 & 0.00 & 0.41 & 0.00 & 0.00 & 0.36 & 5.07 \\
\hline 5 & 0.19 & 0.00 & 0.03 & 0.39 & $0.00(e)$ & 0.00 & 0.00 & 0.15 & 0.00 & 0.00 & 0.49 & 0.05 \\
\hline 6 & 0.00 & 0.00 & 0.00 & 0.00 & $0.00(c)$ & 0.00 & 0.00 & 1.25 & 0.00 & 0.00 & 0.00 & 0.00 \\
\hline 7 & 0.34 & 0.00 & 0.04 & 0.00 & $0.00(e)$ & 0.00 & 0.00 & 0.00 & 0.00 & 0.00 & 0.00 & 0.00 \\
\hline 8 & 0.34 & 0.00 & 0.02 & 0.00 & $0.04(c)$ & 0.00 & 0.00 & 0.00 & 0.00 & 0.00 & $0.00(e)$ & 0.00 \\
\hline 9 & 0.00 & 0.00 & 0.00 & 0.85 & $0.00(\mathrm{e})$ & 0.00 & 0.00 & 0.00 & 0.00 & 0.36 & $0.00(e)$ & 0.29 \\
\hline 10 & 0.03 & 0.00 & 0.00 & 0.02 & $0.00(e)$ & 0.00 & 0.00 & 0.00 & 0.00 & 0.00 & $0.00(e)$ & 0.71 \\
\hline 11 & 0.78 & 0.66 & 0.00 & 0.00 & $0.00(e)$ & 0.00 & 0.00 & 0.20 & 0.00 & 0.14 & 0.00 & 0.00 \\
\hline 12 & 0.12 & 0.09 & 0.09 & 0.00 & $0.00(\mathrm{e})$ & 0.00 & 0.00 & 0.22 & 0.00 & $0.00(\mathrm{c})$ & 0.00 & 0.00 \\
\hline 13 & 0.02 & 0.00 & 0.01 & 0.00 & 0.45 & 0.60 & 0.47 & 0.37 & 0.00 & $0.00(e)$ & 0.00 & 0.00 \\
\hline 14 & 0.00 & 0.00 & 0.18 & 0.00 & 0.00 & 0.53 & 0.33 & 0.01 & 0.00 & 0.00 & 0.86 & 0.32 \\
\hline 15 & 0.00 & 0.04 & 0.61 & 0.88 & 0.00 & 0.04 & 0.14 & 0.00 & 0.82 & 0.00 & 0.25 & 0.09 \\
\hline 16 & 0.00 & 0.71 & 0.01 & 0.02 & 0.01 & 0.00 & 0.00 & 0.00 & 0.72 & 0.22 & 0.02 & 0.00 \\
\hline 17 & 0.00 & 0.01 & 0.32 & 0.00 & 0.00 & 0.00 & 0.56 & 0.25 & 0.00 & 0.09 & 0.47 & 0.00 \\
\hline 18 & 0.00 & 0.00 & 0.00 & 0.00 & 0.52 & 0.04 & 0.00 & 0.28 & $0.00(c)$ & 0.00 & 0.00 & 0.02 \\
\hline 19 & 0.03 & 0.00 & 0.00 & 0.00 & 0.45 & 0.26 & 0.46 & 0.00 & $0.00(\mathrm{e})$ & 0.00 & 0.00 & 0.00 \\
\hline 20 & 0.05 & 0.03 & 0.11 & 0.87 & 0.08 & 0.00 & 0.00 & 0.04 & $0.00(c)$ & 0.00 & 0.00 & 0.62 \\
\hline 21 & 0.41 & 1.88 & 0.00 & 0.00 & 0.18 & 0.03 & 0.00 & 0.00 & $0.00(e)$ & 0.36 & 0.00 & 0.03 \\
\hline 22 & 0.00 & 0.00 & 0.14 & 0.00 & 0.00 & 0.00 & 0.00 & 0.00 & $0.00(c)$ & 0.00 & 0.00 & 0.00 \\
\hline 23 & 0.00 & 0.00 & 262 & 0.00 & 0.00 & 0.00 & 0.00 & 0.00 & 0.86 & 0.00 & 0.00 & 0.02 \\
\hline 24 & 1.13 & 0.00 & 0.01 & 0.00 & 0.00 & 0.00 & 0.00 & 0.00 & 0.00 & 0.00 & 0.00 & 0.00 \\
\hline 25 & 0.00 & 0.01 & 0.02 & 0.81 & 0.14 & 0.00 & 0.05 & 0.00 & 0.33 & 0.00 & 0.00 & 0.02 \\
\hline 26 & 0.00 & 0.45 & 0.59 & 0.11 & 0.02 & 0.02 & 0.00 & 0.00 & 0.54 & 0.00 & 0.62 & 0.00 \\
\hline 27 & 0.00 & 0.00 & 0.58 & 0.00 & 0.00 & 0.00 & 0.89 & 0.00 & 0.49 & 0.00 & 0.47 & 0.00 \\
\hline 28 & 0.00 & 0.00 & 0.00 & 0.00 & 0.00 & 0.00 & 0.00 & 0.00 & 0.00 & 0.00 & 0.00 & 0.88 \\
\hline 29 & 0.00 & & 0.00 & 0.00 & 0.42 & 0.00 & 0.00 & 0.00 & 0.00 & 0.26 & 0.00 & 0.03 \\
\hline 30 & 0.00 & & 0.00 & 0.00 & 0.23 & 0.58 & 0.00 & 0.00 & 0.00 & 0.39 & 0.00 & 0.00 \\
\hline 31 & 0.00 & & 0.51 & & 0.63 & & 0.00 & 0.00 & & 0.07 & & 0.00 \\
\hline TOTAL & 4.07 & 3.88 & 7.09 & 4.18 & 3.63 & 210 & 290 & 3.23 & 5.49 & 212 & 3.56 & 8.40 \\
\hline MEAN & 0.13 & 0.14 & 0.23 & 0.14 & 0.12 & 0.07 & 0.09 & 0.10 & 0.18 & 0.07 & 0.12 & 0.27 \\
\hline MAX & 1.13 & 1.88 & 262 & 0.88 & 0.63 & 0.60 & 0.89 & 1.25 & 1.64 & 0.39 & 0.86 & 5.07 \\
\hline
\end{tabular}

(c) - Data from station other than BUR 
Table A.10. Daily precipitation totals at the NOAAVATDD raingage in Oak Ridge for the period January-December 1993

(units=in)

\begin{tabular}{|c|c|c|c|c|c|c|c|c|c|c|c|c|}
\hline DAY & JAN & FEB & MAR & APR & MAY & JUN & JUL & AUG & SEP & OCT & NOV & DEC \\
\hline 1 & 0.00 & 0.00 & 0.00 & $0.00(t)$ & 0.00 & 0.00 & 0.00 & 0.00 & 0.00 & 0.00 & 0.00 & 0.00 \\
\hline 2 & 0.00 & 0.00 & 0.18 & 0.11 & 0.00 & 0.00 & 0.00 & 0.07 & 0.10 & 0.26 & 0.00 & 0.00 \\
\hline 3 & 0.00 & 0.00 & 0.59 & 0.05 & $0.00(t)$ & 0.00 & 0.00 & 0.00 & 1.71 & 0.00 & $0.00(t)$ & 0.18 \\
\hline 4 & 0.47 & 0.00 & 0.43 & 0.02 & 0.50 & $0.00(t)$ & 0.00 & $0.00(t)$ & 0.04 & 0.00 & 0.46 & 4.89 \\
\hline 5 & 0.18 & 0.00 & 0.00 & 0.44 & 0.00 & $0.00(t)$ & 0.00 & 0.01 & 0.00 & 0.00 & 0.56 & 0.04 \\
\hline 6 & 0.00 & 0.00 & 0.00 & 0.00 & 0.00 & 0.00 & 0.00 & 1.34 & 0.00 & 0.00 & 0.00 & 0.00 \\
\hline 7 & 0.34 & 0.00 & 0.04 & 0.00 & 0.00 & 0.00 & 0.00 & 0.00 & 0.00 & 0.00 & 0.00 & 0.00 \\
\hline 8 & 0.38 & 0.00 & 0.01 & 0.00 & 0.48 & 0.00 & 0.00 & 0.00 & $0.00(t)$ & $0.00(t)$ & 0.00 & 0.00 \\
\hline 9 & 0.00 & 0.00 & 0.00 & 0.76 & 0.00 & 0.00 & 0.00 & 0.00 & 0.01 & 0.39 & $0.00(t)$ & 0.20 \\
\hline 10 & 0.06 & 0.00 & 0.00 & 0.00 & 0.00 & 0.02 & $0.00(t)$ & 0.00 & 0.00 & 0.00 & 0.00 & 0.91 \\
\hline 11 & 0.81 & 0.63 & 0.00 & 0.00 & 0.00 & 0.00 & 0.00 & 0.43 & 0.00 & 0.11 & 0.00 & $0.00(t)$ \\
\hline 12 & 0.05 & 0.10 & 0.22 & 0.00 & 0.00 & $0.00(t)$ & 0.02 & 0.35 & 0.00 & 0.00 & 0.00 & 0.00 \\
\hline 13 & 0.09 & 0.00 & 0.70 & 0.00 & 0.11 & 0.22 & 0.18 & 0.82 & 0.00 & 0.00 & 0.00 & 0.00 \\
\hline 14 & 0.00 & 0.00 & 0.00 & 0.00 & 0.00 & 0.60 & 0.06 & 0.02 & 0.00 & 0.00 & 1.00 & 0.22 \\
\hline 15 & 0.00 & 0.05 & 0.00 & 0.61 & 0.00 & 0.06 & 0.27 & 0.00 & 1.08 & $0.00(t)$ & 0.36 & 0.10 \\
\hline 16 & 0.00 & 0.66 & 0.00 & $0.00(t)$ & 0.10 & 0.00 & $0.00(t)$ & 0.00 & 0.58 & 0.15 & 0.03 & 0.00 \\
\hline 17 & 0.00 & 0.00 & 0.33 & 0.00 & 0.00 & 0.00 & 0.40 & 0.10 & 0.00 & 0.15 & 0.60 & 0.00 \\
\hline 18 & 0.00 & 0.00 & 0.00 & 0.00 & 0.70 & 0.01 & 0.00 & 0.03 & 0.00 & 0.05 & 0.00 & 0.03 \\
\hline 19 & 0.03 & 0.00 & 0.00 & 0.00 & 0.47 & 0.38 & 0.20 & 0.00 & 0.00 & 0.00 & $0.00(t)$ & 0.00 \\
\hline 20 & 0.10 & 0.09 & 0.00 & 0.76 & 0.12 & 0.00 & 0.00 & 0.08 & $0.00(t)$ & 0.00 & $0.00(t)$ & 0.64 \\
\hline 21 & 0.41 & 2.13 & 0.00 & 0.05 & 0.05 & 0.02 & 0.00 & 0.00 & 0.00 & 0.35 & 0.00 & 0.03 \\
\hline 22 & 0.00 & 0.00 & 0.05 & 0.00 & 0.00 & 0.00 & 0.01 & 0.00 & 0.00 & 0.00 & 0.00 & $0.00(t)$ \\
\hline 23 & 0.00 & 0.00 & 237 & 0.00 & 0.00 & 0.00 & 0.00 & 0.00 & 0.24 & 0.00 & 0.00 & 0.05 \\
\hline 24 & 1.06 & 0.00 & 0.00 & 0.00 & 0.00 & 0.05 & 0.00 & 0.00 & 0.00 & 0.00 & 0.00 & 0.00 \\
\hline 25 & 0.00 & 0.47 & 0.03 & 0.74 & 0.14 & 0.00 & 0.03 & $0.00(t)$ & 0.42 & 0.00 & $0.00(t)$ & $0.00(t)$ \\
\hline 26 & 0.00 & 0.00 & 0.53 & 0.16 & 0.05 & 0.02 & 0.00 & 0.00 & 0.48 & 0.00 & 0.56 & 0.00 \\
\hline 27 & 0.00 & 0.00 & 0.57 & 0.00 & 0.00 & $0.00(t)$ & 0.82 & 0.00 & 0.46 & 0.00 & 0.52 & 0.00 \\
\hline 28 & 0.00 & 0.00 & 0.00 & 0.00 & 0.00 & 0.00 & 0.00 & 0.00 & 0.00 & 0.00 & 0.00 & 0.99 \\
\hline 29 & 0.00 & & 0.00 & 0.00 & 0.64 & 0.00 & 0.00 & 0.00 & 0.00 & 0.19 & 0.00 & 0.01 \\
\hline 30 & 0.00 & & 0.00 & 0.00 & 0.30 & 0.22 & 0.00 & 0.00 & 0.00 & 0.40 & 0.00 & 0.00 \\
\hline 31 & 0.00 & & 0.37 & & 0.63 & & 0.00 & 0.00 & & 0.10 & & 0.00 \\
\hline TOTAL & 3.98 & 4.13 & 6.42 & 3.70 & 4.29 & 1.60 & 1.99 & 3.25 & 5.12 & 215 & 4.09 & 8.29 \\
\hline MEAN & 0.13 & 0.15 & 0.21 & 0.12 & 0.14 & 0.05 & 0.06 & 0.11 & 0.17 & 0.07 & 0.14 & 0.27 \\
\hline MAX & 1.06 & 213 & 237 & 0.76 & 0.70 & 0.60 & 0.82 & 1.34 & 1.71 & 0.40 & 1.00 & 4.89 \\
\hline
\end{tabular}

(t) - Trace 
Appendix B

DESCRIPTIONS OF SURFACE WATER MONITORING STATIONS

IN THE WHITE OAK CREEK WATERSHED 



\section{White Oak Dam (WOD, X15, MS5)}

Physical description: Station is at the outfall of WOL where WOC flows under State Highway 95, $1 \mathrm{~km}(0.6 \mathrm{mi})$ above the confluence with the Clinch River. Waters impounded by WOD flow through two $5.5 \mathrm{~m}$ (18ft) sluice gates, through a $12.2 \mathrm{~m}(40 \mathrm{ft})$ wide channel; across a triangular, concrete, broad-crested weir (high-flow control); and finally, across a stainless steel, sharp-crested (trapezoidal) weir (low-flow control) before spilling into the White Oak Creek embayment. The notch (crest) elevations on the broad- and sharp-crested weirs are about $226.8 \mathrm{~m}(744.0 \mathrm{ft})$ and $226.6 \mathrm{~m}(743.5 \mathrm{ft}) \mathrm{MSL}$, respectively. Normal pool elevation for WOL is about 227.1 (745 ft) MSL. Maximum lake elevation (without overtopping the gates) with the gates closed is about $228.6 \mathrm{~m}$ (750 ft) MSL. Crest elevation of WOD is about $230.13 \mathrm{~m}$ (755.05 ft) MSL at its lowest point near the longitudinal center (Tschantz, 1987).

Monitoring status: ESPS collects daily (totalizer) discharge data by ultrasonic flow meters for compliance purposes. ESD's Surface Water Hydrology Group collects stage height data at four sensor locations, including lake level, for conversion to discharge data.

\section{White Oak Creek (WOC, X14, MS3)}

Physical description: Station is on WOC above the confluence with MB. Water flows into a stilling pool impounded by a concrete sill; through twin stainless steel, sharpcrested, $100^{\circ} \mathrm{V}$-notch weirs contained in the sill; into a $11.0 \mathrm{~m}$ (36 ft) wide channel; then across a rectangular, concrete, broad-crested weir before finally spilling back into the natural channel downstream from the station. The elevations of the top of the V-notch weirs, the crests of the V-notch weirs, and the broad-crested weir are about $230.21 \mathrm{~m}$, $229.45 \mathrm{~m}$, and $229.21 \mathrm{~m}(755.48,753.00$, and $752.23 \mathrm{ft}) \mathrm{MSL}$, respectively.

Monitoring status: ESPS collects daily (totalizer) discharge data by ultrasonic flow meters for compliance purposes. ESD's Surface Water Hydrology Group collects stage height data at three sensor locations for conversion to discharge data.

\section{Melton Branch (MB, X13, MS4)}

Physical description: Station is on MB above the confluence with WOC. Water flows are impounded by a concrete sill, through a stainless steel, sharp-crested, $120^{\circ} \mathrm{V}$-notch

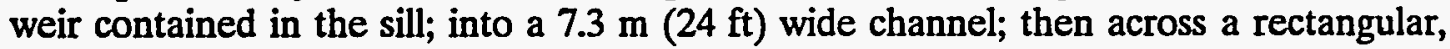
concrete, broad-crested weir before finally spilling into a tailwater pool downstream from the station. The elevations of the top of the V-notch weir, the crests of the V-notch weir, and the broad-crested weir are about $230.3 \mathrm{~m}, 229.6 \mathrm{~m}$, and $229 \mathrm{~m}$ (755.90, 753.67, and $752.31 \mathrm{ft}$ ) MSL, respectively.

Monitoring status: ESPS collects daily (totalizer) discharge data by ultrasonic flow meters for compliance purposes. ESD's Surface Water Hydrology Group collects stage height data at three sensor locations for conversion to discharge data. 


\section{White Oak Creek Headwaters (WOCHW)}

Physical description: Station is in the upper reaches of WOC, north of Bethel Valley Road and upstream from any ORNL facility discharges. Therefore, this station is considered a background monitoring station for WOC. The control device is a compound, stainless steel, critical-flow flume.

Monitoring status: Instrumentation includes a Stevens model 7001 float-type gage housed over $a$ stilling well and equipped with a digital punch, stage-height recorder. ESD's Surface Water Hydrology Group operates electronic and mechanical data loggers; maintains instrumentation; collects punch-tapes and electronic data storage packs; processes tapes and storage packs; and generates, verifies, and stores discharge data. ESPS operates a flow totalizer at this station.

\section{East Seep (ESP)}

Physical description: Station is in WAG 7 on the east seep tributary to the headwaters of WOL. The control device is a stainless steel, sharp-crested, $90^{\circ} \mathrm{V}$-notch weir.

Monitoring status: ESD's Surface Water Hydrology Group operates electronic and mechanical data loggers; maintains instrumentation; collects punch tapes and electronic data storage packs; processes tapes and storage packs; and generates, verifies, and stores discharge data.

\section{West Seep (WSP)}

Physical description: Station is in WAG 2 bordering the east slope of WAG 6 on the west seep tributary to the headwaters of WOL. The control device is a compound, stainless steel, sharp-crested, weir consisting of a $120^{\circ} \mathrm{V}$-notch, low-flow section and a rectangular, high-flow section.

Monitoring status: Instrumentation includes a Stevens model 7001 float-type gage housed over a stilling well and equipped with a digital punch, stage-height recorder. ESD's Surface Water Hydrology Group maintains instrumentation; collects punch tapes; processes the tapes; and generates, verifies, and stores discharge data.

\section{Raccoon Creek}

Physical description: Station is in the upper reaches of Raccoon Creek, approximately $0.4 \mathrm{~km}(0.25 \mathrm{mi})$ west of State Highway $95,0.15 \mathrm{~km}(0.1 \mathrm{mi})$ south of New Zion Patrol Road, and $2.1 \mathrm{~km}$ (1.3 mi) upstream from the mouth at Clinch River kilometer 31.5 (mile 19.5). The control device is a stainless steel, sharp-crested weir in three sections: a $56^{\circ}$ $V$-notch in the center of the channel for stages from 0 to $1.25 \mathrm{ft}$; and a vertical extension of the V-notch and two rectangular weir plates with end contractions, one on each side of the V-notch, for stages from 1.25 to $2.5 \mathrm{ft}$.

Monitoring status: Instrumentation includes a Stevens model 7001 float-type gage housed over a stilling well and equipped with a digital punch, stage-height recorder. 
ESD's Surface Water Hydrology Group maintains instrumentation; collects punch tapes; processes the tapes; and generates, verifies, and stores discharge data.

\section{Ish Creek}

Physical description: Station is at the bridge on New Zion Patrol Road, $2.7 \mathrm{~km}$ (1.7 mi) west of State Highway 95 and $0.6 \mathrm{~km}(0.4 \mathrm{mi})$ upstream from the mouth at Clinch River kilometer 30.7 (mile 19.1). The low-flow control device is a stainless steel, critical flow flume, and the high-flow control device is the rectangular, concrete, culvert (bridge) opening.

Monitoring status: Monitoring by ESD was discontinued at the end of February 1993.

\section{Melton Branch Tributary (HRT)}

Physical description: Station is on the tributary to MB in the vicinity of the old Homogenous Reactor Test Facility. The control device is a stainless steel, sharp-crested, $90^{\circ} \mathrm{V}$-notch weir.

Monitoring status: Instrumentation includes an Omnidata Easy Logger (electronic data logger) with a submerged pressure transducer installed in the approach channel for measuring stage. ESD's Surface Water Hydrology Group maintains the instrumentation, retrieves data storage packs, and downloads and archives data.

10. WAG4-2 (MS1)

Physical description: Station is on the upper reaches of an unnamed tributary to White Oak Creek that runs along the southern boundary of SWSA 4. Access to the site is through SWSA 4 from Lagoon Road. The control device is a Plasti-fab, prefabricated fiberglass, $5 \mathrm{~cm}(2 \mathrm{in}), 45^{\circ}$ trapezoidal flume.

Monitoring status: Instrumentation includes an Omnidata Easy Logger (electronic data logger) with a submerged pressure transducer installed in the stilling pool for measuring stage. ESD's Surface Water Hydrology Group maintains the instrumentation; retrieves data storage packs; and downloads and archives data.

\section{WAG4-2A (T2A)}

Physical description: Station is just above the mouth of an unnamed tributary to White Oak Creek that runs along the southern boundary of SWSA 4 in the vicinity of the old intermediate detention pond. The control device is a Plasti-Fab prefabricated fiberglass, $12.7 \mathrm{~cm}$ (5 in), $45^{\circ}$ trapezoidal flume.

Monitoring status: Instrumentation includes an Omnidata Easy Logger (electronic data logger) with a submerged pressure transducer installed in the approach channel for measuring stage. ESD's Surface Water Hydrology Group maintains the instrumentation, retrieves data storage packs, and downloads and archives data. 
12. Melton Branch (MB2)

Physical description: Station is on MB upstream from the confluence with the HRT (Homogenous Rector Test Facility) tributary. The control device is a $1.83 \mathrm{~m}(6 \mathrm{ft})$ wide, stainless steel, sharp-crested, trapezoidal weir.

Monitoring status: ESPS operates a flow totalizer at this station.

\section{Melton Branch Tributary (HRTF)}

Physical description: Station is on the tributary to Melton Branch in the vicinity of the old Homogenous Reactor Test Facility upstream from the confluence with MB and downstream from station HRT (\#14 below). The control device is a Manning $0.46 \mathrm{~m}$ (18 in), prefabricated fiberglass Palmer-Bowlus flume.

Monitoring status: No monitoring is conducted at this station. Some limited stage data were collected by ESD from August 1989 to January 1990 for an independent study on storm-flow sampling. These data are available in electronic files but have not been processed.

14. WAG 6 Tributaries (FA, FB, DA, and DB)

Physical description: Stations are on the four drainages in WAG 6 (all draining into White Oak Lake). Proceeding west to east: station FA is a $5 \mathrm{~cm}(2 \mathrm{in}), 60^{\circ}$ trapezoidal flume; station $\mathrm{FB}$ is a $15 \mathrm{~cm}$ (6 in) parshall flume; station DA is a $0.46 \mathrm{~m}$ (18 in) parshall flume; and station DB consists of $15 \mathrm{~cm}$ and $0.91 \mathrm{~m}$ (6 in and $36 \mathrm{in}$ ) parshall flumes in series. All flumes are prefabricated fiberglass flumes with dual $0.3 \mathrm{~m}$ (12 in) stilling wells for upstream (H1) and downstream (H2) head measurements.

Monitoring status: ESD's Surface Water Hydrology Group collected data at all four stations for a brief period, from about late April to early June of 1990. All four stations were reinstrumented in the spring of 1992 by the Interim Corrective Measures (ICM) monitoring program for discharge data collection and water quality sampling.

\section{White Oak Creek and Clinch River Confluence}

Physical description: Station is at the mouth of WOC on the Clinch River at Clinch River mile 20.8. Station is a stage recorder only (no control device).

Monitoring status: Instrumentation includes an Omnidata Easy Logger (electronic data logger) with a submerged pressure transducer installed in the approach channel for measuring stage. ESD's Surface Water Hydrology Group maintains the instrumentation, retrieves data storage packs, and downloads and archives data. 
16. First Creek (GS1, USGS \#03536450)

Physical description: Station is on the First Creek tributary to WOC (above) between Burial Ground Road and the confluence with the Northwest tributary. The control device is a compound, stainless steel, critical-flow flume.

Monitoring status: USGS instrumentation includes a Stevens model 7001 float-type gage housed over a stilling well and equipped with a digital punch, stage-height recorder. The gage collects raw stage data at 5-min intervals for conversion to hourly average discharge values.

\section{Upper Melton Branch (GS2, USGS \#03537100)}

Physical description: Station is in the upper reaches of MB near the proposed SWSA 7, 1.6 kilometers ( 1 mile) southeast of ORNL, just upstream from the HFIR complex. The control device is a "natural" concrete overflow sill with a broad, flat, triangular notch.

Monitoring status: USGS instrumentation includes a Stevens model 7001 float-type gage housed over a stilling well and equipped with a digital punch, stage-height recorder that collects raw stage data at 15 -min intervals for conversion to hourly average discharge values.

18. 7500 Bridge (MS2A, GS3, USGS \#03536550)

Physical description: Station is on WOC below the confluence with First Creek and Northwest Tributary where Melton Valley Drive meets Lagoon Road. The control device is a compound stainless steel sharp-crested weir consisting of a low-flow trapezoidal section, a trapezoidal transition section, and a rectangular high-flow section.

Monitoring status: USGS instrumentation includes a bubbler gage equipped with a digital punch, stage-height recorder that transmits stage data via a satellite telemetry system to the USGS data base in Nashville, TN. Stage or converted discharge data are available in near real-time for immediate access, and are also processed to produce online computer summaries of data. This site also has a raingage that is part of the DCP system in use. In addition, ESPS operates a flow totalizer at this station.

\section{Northwest Tributary (NWT, GS4, USGS \#03536440)}

Physical description: Station is on the Northwest tributary to WOC above the confluence with First Creek, southwest of the fish ponds behind Building 1504, ORNL. The control device is a concrete and stainless steel, short-crested triangular weir.

Monitoring status: USGS instrumentation includes a bubbler gage equipped with a digital punch, stage-height recorder. The gage collects raw stage data at 15-min intervals for conversion to hourly average discharge values. ESPS operates a flow totalizer at this station. 
20. White Oak Creek Parshall Flume (MS2, GS5, USGS \#03536380)

Physical description: Station is at the existing MS2 concrete and stainless steel, parshall flume on WOC in the main plant area downstream from the confluence with Fifth Creek and upstream from the STP outfall.

Monitoring status: USGS instrumentation includes a Stevens model 7001 float-type gage housed over a stilling well and mounted at the upstream side of the concrete structure containing the flume, near the left bank. The gage is equipped with a digital punch, stage-height recorder that collects raw stage data at 15 -min intervals for conversion to hourly average discharge values.

21. Upper White Oak Creek (GS6, USGS \#03536320)

Physical description: Station is on WOC east of the east gate outside the main plant area and north of the point where WOC crosses White Oak Avenue, near Building 6000, ORNL. The control is a natural bedrock outcropping in the stream.

Monitoring status: The USGS instrumentation includes a Stevens model 7001 float-type gage housed in an instrument shelter over a stilling well on the right bank of the stream. The gage is equipped with a digital punch, stage-height recorder that collects raw stage data at 15 -min intervals for conversion to hourly average discharge values.

22. Melton Branch Tributary (East Seven, E7C, GS16, USGS \#03537050)

Physical description: Station is on the east tributary (East Seven Creek) to MB adjacent to the proposed SWSA 7. The control device is a prefabricated fiberglass H-flume.

Monitoring status: USGS monitoring was discontinued at the end of September 1993.

23. Melton Branch Tributary (Center Seven, C7C, GS17, USGS \#03537200)

Physical description: Station is at the center of three tributaries (Center Seven Creek) to MB, adjacent to the proposed SWSA 7. The low-flow control device is a stainless steel, sharp-crested, $90^{\circ} \mathrm{V}$-notch weir and the high-flow control device is a $0.76 \mathrm{~m}$ $(2.5 \mathrm{ft})$, fiberglass $\mathrm{H}$-flume.

Monitoring status: USGS monitoring was discontinued at the end of September 1993. ESD monitoring (collection of stage data) was discontinued at the end of December 1993.

24. Melton Branch Tributary (West Seven, W7C, GS18, USGS \#03537300)

Physical description: Station is on the west tributary (West Seven Creek) to MB adjacent to the proposed SWSA 7. The control device is a combination stainless steel rectangular $/ 90^{\circ} \mathrm{V}$-notch weir.

Monitoring status: USGS monitoring was discontinued at the end of September 1993. 
25. Walker Branch East (WBE)

Physical description: Station is on the east fork of Walker Branch about $0.9 \mathrm{~km}(0.6 \mathrm{mi})$ upstream from the mouth of Walker Branch at Clinch River and Bethel Valley Road; 0.05 $\mathrm{km}(0.03 \mathrm{mi})$ upstream from the confluence of the east and west forks of Walker Branch; and about $3.5 \mathrm{~km}$ (2.2 mi) northeast of the 7000 area of ORNL. The control device is a $120^{\circ} \mathrm{V}$-notch stainless steel weir set in a concrete dam.

Monitoring status: Instrumentation includes a Stevens model 7001 float-type gage housed over a stilling well and equipped with a digital punch, stage-height recorder. ESD's Surface Water Hydrology Group maintains the instrumentation; collects punch-tapes; processes the tapes; and generates, verifies, and stores discharge data.

\section{Walker Branch West (WBW)}

Physical description: Station is on the west fork of Walker Branch about $0.9 \mathrm{~km}(0.6 \mathrm{mi})$ upstream from the mouth of Walker Branch at Clinch River and Bethel Valley Road; 0.05 $\mathrm{km}(0.03 \mathrm{mi})$ upstream from the confluence of the east and west forks of Walker Branch; and about $3.5 \mathrm{~km}(2.2 \mathrm{mi})$ northeast of the 7000 area of ORNL. The control device is a $120^{\circ} \mathrm{V}$-notch stainless steel weir set in a concrete dam.

Monitoring status: Instrumentation includes a Stevens model 7001 float-type gage housed over a stilling well and equipped with a digital punch, stage-height recorder. ESD's Surface Water Hydrology Group maintains the instrumentation; collects punch-tapes; processes the tapes; and generates, verifies, and stores discharge data. 
Appendix C

DAIIY STREAMFLOW FOR MONITORING STATIONS

IN WHITE OAK CREEK WATERSHED 

Table C.1. Daily streamflow (cfs) at the White Oak Creek (MS3) monitoring station for the period January-December 1993

\begin{tabular}{|c|c|c|c|c|c|c|c|c|c|c|c|c|}
\hline DAY & JAN & FEB & MAR & APR & MAY & JUN & JUL & AUG & SEP & OCT & Nov & DEC \\
\hline 1 & 9.64 & 7.58 & 9.73 & 21.9 & 8.33 & 5.60 & 6.80 & 5.14 & 5.09 & 4.45 & 4.73 & 5.62 \\
\hline 2 & 8.30 & 7.14 & 10.3 & 16.7 & 7.54 & 5.31 & 5.67 & 5.47 & 5.73 & 4.79 & 4.49 & 5.25 \\
\hline 3 & 7.54 & 6.85 & 13.9 & 13.6 & 7.32 & 5.31 & 5.37 & 5.51 & 7.64 & 4.48 & 4.78 & 5.34 \\
\hline 4 & 10.3 & 6.63 & 38.0 & 121 & 10.8 & 5.34 & 5.23 & 8.62 & 10.6 & 4.35 & 5.44 & 158 \\
\hline 5 & 19.0 & 6.58 & 19.9 & 16.5 & 7.64 & 5.05 & 5.07 & 5.75 & 5.09 & 4.32 & 11.9 & 45.7 \\
\hline 6 & 125 & 6.12 & 14.6 & 126 & 6.90 & 4.45 & 5.06 & 17.8 & 4.65 & 4.41 & 6.19 & 19.5 \\
\hline 7 & 120 & 6.11 & 123 & 11.3 & 6.64 & 4.94 & 5.26 & 6.75 & 4.94 & 4.55 & 5.66 & 11.4 \\
\hline 8 & 23.4 & 6.14 & 10.7 & 10.4 & 6.41 & 4.89 & 6.49 & 6.05 & 5.04 & 4.80 & 5.09 & 9.05 \\
\hline 9 & 15.8 & 6.11 & 9.87 & 25.9 & 5.76 & 5.09 & 5.33 & 5.65 & 5.15 & 5.79 & 5.01 & 8.12 \\
\hline 10 & 129 & 5.96 & 9.18 & 18.8 & 6.08 & 5.24 & 5.33 & 5.42 & 4.73 & 4.54 & 4.77 & 23.4 \\
\hline 11 & 26.3 & 9.05 & 8.15 & 14.7 & 6.27 & 5.13 & 5.28 & 5.87 & 4.34 & 4.71 & 4.64 & 123 \\
\hline 12 & 20.8 & 9.27 & 8.02 & 12.5 & 5.71 & 4.92 & 5.61 & 6.07 & 4.07 & 4.67 & 4.79 & 9.64 \\
\hline 13 & 16.1 & 6.98 & 9.73 & 11.0 & 7.29 & 6.29 & 5.82 & 6.91 & 4.15 & 4.45 & 5.01 & 8.31 \\
\hline 14 & 129 & 6.26 & 9.31 & 10.2 & 6.04 & 5.32 & 5.86 & 5.60 & 4.03 & 4.36 & 9.23 & 8.87 \\
\hline 15 & 11.4 & 6.01 & 9.09 & 17.8 & 5.43 & 11.0 & 8.48 & 5.20 & 5.88 & 4.68 & 14.3 & 9.07 \\
\hline 16 & 10.4 & 19.3 & 126 & 13.5 & 5.30 & 5.91 & 6.05 & 4.82 & 5.06 & 5.54 & 6.97 & 7.46 \\
\hline 17 & 9.09 & 12.1 & 29.8 & 10.6 & 5.78 & 5.39 & 8.22 & 4.77 & 4.86 & 4.76 & 8.43 & 6.92 \\
\hline 18 & 8.36 & 9.76 & 221 & 9.67 & 5.97 & 5.29 & 5.57 & 6.64 & 4.59 & 5.01 & 6.95 & 6.81 \\
\hline 19 & 7.69 & 8.93 & 16.4 & 9.27 & 10.1 & 7.15 & 5.94 & 4.96 & 4.51 & 4.61 & 6.11 & 6.15 \\
\hline 20 & $7 / 31$ & 8.33 & 13.8 & 16.4 & 5.91 & 5.03 & 6.11 & 5.04 & 4.53 & 4.98 & 5.63 & 8.73 \\
\hline 21 & 11.7 & 54.2 & 11.9 & 14.7 & 6.55 & 5.55 & 6.36 & 4.64 & 4.61 & 9.22 & 5.30 & 11.9 \\
\hline 22 & 8.53 & 29.7 & 11.0 & 120 & 5.44 & 5.47 & 5.67 & 4.59 & 4.46 & 5.29 & 5.15 & 8.65 \\
\hline 23 & 7.54 & 18.0 & 11.4 & 10.9 & 4.97 & 5.42 & 5.38 & 4.76 & 10.4 & 4.70 & 5.61 & 7.72 \\
\hline 24 & 36.5 & 13.6 & 49.5 & 9.71 & 5.55 & 5.32 & 5.15 & 4.82 & 5.58 & 4.44 & 5.50 & 6.59 \\
\hline 25 & 19.9 & 124 & 25.2 & 10.7 & 5.79 & 5.26 & 5.07 & 4.79 & 7.36 & 4.61 & 5.11 & 6.35 \\
\hline 26 & 15.3 & 14.4 & 229 & 229 & 5.52 & 5,30 & 5.20 & 4.88 & 6.99 & 4.81 & 7.36 & 6.07 \\
\hline 27 & 125 & 11.6 & 44.7 & 125 & 5.17 & 4.92 & 5.29 & 4.73 & 9.89 & 4.53 & 120 & 5.77 \\
\hline 28 & 10.9 & 10.4 & 26.3 & 11.4 & 5.31 & 5.24 & 5.73 & 4.64 & 5.42 & 4.55 & 7.91 & 129 \\
\hline 29 & 9.46 & & 18.4 & 10.3 & 5.13 & 5.55 & 5.69 & 4.72 & 4.95 & 4.70 & 6.59 & 15.4 \\
\hline 30 & 8.57 & & 14.8 & 9.51 & 4.98 & 10.6 & 5.53 & 4.87 & 4.66 & 7.72 & 5.75 & 11.0 \\
\hline 31 & 7.95 & & 28.1 & & 8.01 & & 5.34 & 4.96 & & 5.11 & & 9.85 \\
\hline TOTAL & 410 & 324 & 654 & 409 & 199 & 171 & 178 & 180 & 169 & 153 & 196 & 478 \\
\hline MEAN & 13.2 & 11.6 & 21.1 & 13.7 & 6.44 & 5.71 & 5.77 & 5.82 & 5.64 & 497 & 6.54 & 15.4 \\
\hline MAX & 36.5 & 54.2 & 114 & 25.9 & 10.8 & 11.0 & 8.48 & 17.8 & 10.6 & 9.22 & 14.3 & 158 \\
\hline $\mathbf{M N}$ & 7.31 & 596 & 8.02 & 9.27 & 4.97 & 4.45 & 5.06 & 4.59 & 4.03 & 4.32 & 4.49 & 4.25 \\
\hline $\begin{array}{c}\text { RUNOFF } \\
\text { (iv) }\end{array}$ & 4.23 & 3.34 & 6.74 & 4.22 & 206 & 1.76 & 1.84 & 1.86 & 1.74 & 1.59 & 202 & 4.93 \\
\hline
\end{tabular}


Table C2. Daily streamflow (cfs) at the Melton Branch (MS4) monitoring station for the period January-December 1993

\begin{tabular}{|c|c|c|c|c|c|c|c|c|c|c|c|c|}
\hline DAY & JAN & FEB & MAR & APR & MAY & JUN & JUL & AUG & SEP & OCT & Nov & DEC \\
\hline 1 & 278 & 216 & 268 & 9.95 & 1.63 & .99 & .79 & .34 & .48 & .26 & .39 & .63 \\
\hline 2 & 243 & 1.80 & 288 & 5.64 & 1.54 & .68 & .58 & 39 & .44 & .33 & .37 & .64 \\
\hline 3 & 2.29 & 1.67 & 4.32 & 3.93 & 1.48 & .63 & .54 & .38 & .61 & .35 & .35 & .58 \\
\hline 4 & 3.16 & 1.75 & 17.4 & 3.47 & 282 & .60 & .49 & .68 & .85 & 32 & .39 & 73.1 \\
\hline 5 & 8.65 & 1.74 & 5.72 & 5.97 & 1.50 & .57 & .48 & .46 & .26 & 31 & 215 & 16.1 \\
\hline 6 & 4.47 & 1.71 & 3.62 & 4.52 & 1.22 & .56 & .47 & 256 & .24 & .21 & .68 & 3.69 \\
\hline 7 & 3.67 & 1.53 & 271 & 3.72 & 1.08 & .64 & .43 & .45 & .25 & .20 & .50 & 1.96 \\
\hline 8 & 110 & 1.47 & 239 & 3.21 & 1.00 & .64 & .64 & .26 & .26 & .23 & .47 & 1.34 \\
\hline 9 & 5.97 & 1.45 & 1.92 & 10.3 & .94 & .59 & .81 & .25 & .25 & 37 & .36 & 1.08 \\
\hline 10 & 4.18 & 1.31 & 1.72 & 7.38 & .89 & .63 & .90 & .15 & .26 & .28 & .37 & 8.92 \\
\hline 11 & 120 & 204 & 1.50 & 4.18 & .86 & .64 & .57 & .19 & .21 & .28 & .50 & 3.74 \\
\hline 12 & 8.48 & 3.41 & 1.50 & 3.08 & .83 & .62 & .72 & .92 & .24 & .31 & .43 & 210 \\
\hline 13 & 5.07 & 202 & 234 & 250 & 1.50 & .61 & 1.46 & 1.71 & .25 & .24 & .42 & 1.66 \\
\hline 14 & 3.73 & 1.60 & 207 & 2.13 & .84 & .45 & .78 & 1.30 & .28 & .22 & 1.40 & 1.86 \\
\hline 15 & 3.11 & 1.45 & 230 & 4.16 & .67 & 2.45 & .55 & 1.16 & .48 & 31 & 4.29 & 269 \\
\hline 16 & 257 & 7.26 & 4.10 & 3.94 & .66 & .51 & .45 & .91 & .39 & .37 & 1.28 & 1.92 \\
\hline 17 & 238 & 3.74 & 15.7 & 256 & .76 & .39 & 1.30 & .70 & .36 & .38 & 1.29 & 1.45 \\
\hline 18 & 219 & 274 & 7.91 & 212 & 1.00 & .37 & .68 & .78 & .32 & 32 & 1.07 & 1.22 \\
\hline 19 & 204 & 211 & 4.57 & 1.79 & 4.14 & .52 & .60 & 54 & 29 & .32 & .71 & 1.07 \\
\hline 20 & 1.76 & 202 & 3.51 & 5.26 & 1.12 & .55 & 52 & .56 & .32 & .28 & .53 & 204 \\
\hline 21 & 3.75 & 24.8 & 298 & 6.28 & 1.06 & .60 & .41 & .56 & .35 & .90 & .41 & 4.95 \\
\hline 22 & 3.01 & 8.98 & 269 & 3.41 & .90 & .61 & 33 & .56 & .23 & .41 & .42 & 272 \\
\hline 23 & 262 & 4.08 & 40.9 & 245 & .66 & .52 & .34 & .56 & 1.34 & .32 & .40 & 205 \\
\hline 24 & 20.0 & 298 & 13.3 & 205 & .53 & .52 & .33 & .60 & .44 & .31 & .40 & 1.64 \\
\hline 25 & 7.56 & 273 & 6.02 & 234 & .87 & .57 & .33 & .53 & .60 & .30 & 38 & 1.46 \\
\hline 26 & 4.68 & 4.40 & 5.96 & 10.1 & .89 & .55 & .33 & .58 & .55 & .29 & .88 & 1.17 \\
\hline 27 & 3.53 & 3.90 & 19.6 & 3.65 & .80 & .47 & .33 & .57 & 1.24 & .27 & 3.48 & 1.17 \\
\hline 28 & 3.03 & 3.12 & 8.09 & 262 & .74 & .49 & .28 & .57 & 31 & .25 & 1.76 & 3.93 \\
\hline 29 & 267 & & 4.87 & 212 & .70 & .51 & 31 & .56 & .21 & .28 & 1.03 & 7.20 \\
\hline 30 & 234 & & 3.70 & 1.89 & .72 & 1.07 & 32 & .56 & .17 & .96 & .81 & 3.35 \\
\hline 31 & 210 & & 8.91 & & 1.77 & & .34 & .56 & & .51 & & 241 \\
\hline TOTAL & 147 & 99.9 & 207 & 126 & 36.1 & 19.6 & 17.4 & 20.9 & 125 & 10.7 & 28.0 & 159 \\
\hline MEAN & 4.75 & 3.57 & 6.70 & 4.23 & 1.16 & 0.65 & 56 & .67 & .42 & 34 & .93 & S.16 \\
\hline MAX & 20.0 & 24.8 & 40.9 & 10.3 & 4.14 & 245 & 1.46 & 256 & 1.34 & .96 & 4.29 & 73.1 \\
\hline MIN & 1.76 & 1.31 & 1.50 & 1.79 & 0.53 & 0.37 & .28 & .15 & .17 & .20 & 35 & 58 \\
\hline $\begin{array}{l}\text { RUNOFF } \\
\text { (in) }\end{array}$ & 3.62 & 246 & 5.12 & 3.12 & 0.89 & 0.48 & .43 & 51 & .31 & .26 & .69 & 3.94 \\
\hline
\end{tabular}


Table C.3. Daily streamflow (cfs) at the White Oak Dam (MS5) monitoring station for the period January-December 1993

\begin{tabular}{|c|c|c|c|c|c|c|c|c|c|c|c|c|}
\hline DAY & JAN & FEB & MAR & APR & MAY & JUN & JUL & AUG & SEP & OCT & Nov & DEC \\
\hline 1 & $\mathbf{1 3 . 4}$ & 9.83 & 13.6 & 45.3 & 10.8 & 8.26 & 13.0 & 4.75 & 5.46 & 4.86 & 6.07 & 6.73 \\
\hline 2 & 11.5 & 9.22 & 13.2 & 25.7 & 9.58 & 6.43 & 11.1 & 4.88 & 5.86 & 4.95 & 5.52 & 6.25 \\
\hline 3 & 10.4 & 8.69 & 14.6 & 18.9 & 9.14 & 5.95 & 9.94 & 5.27 & 6.36 & 5.30 & 5.37 & 6.24 \\
\hline 4 & 10.4 & 8.47 & 57.2 & 15.8 & 129 & 6.01 & 9.40 & 7.14 & 125 & 4.78 & 5.72 & 226 \\
\hline 5 & 28.3 & 8.42 & 30.5 & 21.1 & 10.5 & 5.80 & 8.87 & 7.36 & 6.59 & 4.79 & 128 & 100 \\
\hline 6 & 18.0 & 8.17 & 20.0 & 18.5 & 8.76 & 5.27 & 8.45 & 15.6 & 5.29 & 4.71 & 9.26 & 24.4 \\
\hline 7 & 14.6 & 7.91 & 15.7 & 14.8 & 8.11 & 5.21 & 8.28 & 9.15 & 5.08 & 4.69 & 7.02 & 14.7 \\
\hline 8 & 324 & 7.83 & 14.1 & 13.3 & 7.60 & 5.44 & 9.22 & 6.47 & 5.21 & 4.86 & 6.20 & 121 \\
\hline 9 & 24.0 & 7.65 & 129 & 30.7 & 7.13 & 5.47 & 8.60 & 5.70 & 5.26 & 5.40 & 5.84 & 10.5 \\
\hline 10 & 17.5 & 7.26 & 11.9 & 322 & 6.93 & 5.68 & 8.21 & 5.37 & 5.09 & 5.89 & 5.65 & 29.6 \\
\hline 11 & 31.5 & 8.14 & 10.8 & 20.1 & 7.22 & 5.63 & 7.88 & 5.39 & 4.77 & 4.89 & 5.51 & 20.0 \\
\hline 12 & 34.8 & 14.0 & 10.1 & 15.9 & 6.89 & 5.54 & 7.82 & 6.40 & 4.44 & 5.33 & 5.53 & 13.5 \\
\hline 13 & 23.0 & 10.5 & 13.0 & 13.4 & 8.52 & 6.01 & 8.12 & 7.59 & 4.30 & 4.94 & 5.54 & 11.2 \\
\hline 14 & 17.0 & 8.76 & 127 & 11.4 & 9.64 & 6.39 & 8.57 & 6.66 & 4.33 & 4.71 & 6.25 & 10.7 \\
\hline 15 & 14.4 & 7.89 & 11.9 & 17.1 & 6.98 & 123 & 10.4 & 6.05 & 5.63 & 4.80 & 21.7 & 13.2 \\
\hline 16 & 13.7 & 225 & 15.0 & 23.7 & 6.43 & 7.45 & 9.48 & 5.56 & 6.06 & 5.51 & 11.1 & 11.3 \\
\hline 17 & 121 & 16.6 & 43.3 & 14.6 & 6.48 & 6.02 & 10.7 & 5.43 & 5.40 & 5.33 & 9.83 & 9.82 \\
\hline 18 & 10.9 & 13.6 & 36.6 & 13.7 & 6.72 & 5.65 & 10.4 & 8.67 & 5.08 & 5.39 & 9.32 & 9.05 \\
\hline 19 & 10.0 & 11.8 & 23.2 & 126 & 14.5 & 7.12 & 9.32 & 6.64 & 4.71 & 5.13 & 7.51 & 8.34 \\
\hline 20 & 9.47 & 11.0 & 18.1 & 16.7 & 9.31 & 5.98 & 9.33 & 6.01 & 4.64 & 5.14 & 6.60 & 9.43 \\
\hline 21 & 13.1 & 59.6 & 15.4 & 26.9 & 7.89 & 5.75 & 9.54 & 5.81 & 4.64 & 8.65 & 5.86 & 17.4 \\
\hline 22 & 129 & 50.4 & 14.1 & 16.6 & 7.65 & 7.02 & 10.0 & 5.42 & 4.51 & 7.28 & 5.47 & 13.6 \\
\hline 23 & 10.9 & 24.1 & 139 & 14.1 & 6.22 & 8.57 & 8.13 & 5.41 & 2.41 & 5.72 & 5.53 & 11.7 \\
\hline 24 & 50.0 & 16.9 & 84.5 & 23.5 & 6.11 & 9.22 & 5.27 & 5.41 & 9.41 & 5.15 & 5.55 & 9.87 \\
\hline 25 & 33.3 & 14.2 & 35.5 & 122 & 6.48 & 8.97 & 5.10 & 5.43 & 7.76 & 5.04 & 5.45 & 9.07 \\
\hline 26 & 20.4 & 17.1 & 26.6 & 34.0 & 6.93 & 8.90 & 4.95 & 5.58 & 7.50 & 5.12 & 6.31 & 8.59 \\
\hline 27 & 15.6 & 16.2 & 66.9 & 17.9 & 6.28 & 8.85 & 4.96 & 5.46 & 11.5 & 5.12 & 14.1 & 8.03 \\
\hline 28 & 14.0 & 13.9 & 40.9 & 14.4 & 6.06 & 8.94 & 5.17 & 5.44 & 7.26 & 4.97 & 124 & 122 \\
\hline 29 & 127 & & 25.6 & 13.0 & 5.99 & 9.10 & 5.18 & 5.31 & 5.70 & 5.14 & 8.83 & 25.1 \\
\hline 30 & 11.3 & & 19.5 & 121 & 5.93 & 10.9 & 5.10 & 5.31 & 5.03 & 8.57 & 7.34 & 15.4 \\
\hline 31 & 10.3 & & 26.3 & & 9.22 & & 4.98 & 5.37 & & 7.27 & & 13.2 \\
\hline TOTAL & 561 & 420 & 892 & 570 & 248 & 213 & 255 & 196 & 182 & 169 & 235 & 698 \\
\hline MEAN & 18.1 & 15.0 & 28.8 & 19.0 & 8.03 & 7.13 & 8.24 & 6.33 & 6.09 & 5.46 & 7.84 & 225 \\
\hline MAX & 50.0 & 59.6 & 139 & 45.3 & 14.5 & 123 & 13.0 & 15.6 & 125 & 8.65 & 21.7 & 226 \\
\hline $\mathrm{MmN}$ & 9.47 & 7.26 & 10.1 & 11.4 & 5.93 & 5.21 & 4.95 & 4.75 & 4.30 & 4.69 & 5.37 & 6.21 \\
\hline $\begin{array}{l}\text { RUNOFP } \\
\text { (ii) }\end{array}$ & 3.40 & 254 & 5.40 & 3.45 & 1.50 & 1.29 & 1.54 & 1.19 & 1.11 & 1.02 & 1.42 & 4.22 \\
\hline
\end{tabular}


Table C.4. Daily streamflow (cfs) at the White Oak Creek Headwaters (WOCHW) monitoring station for the period January-December 1993

\begin{tabular}{|c|c|c|c|c|c|c|c|c|c|c|c|c|}
\hline DAY & JAN & FEB & MAR & APR & MAY & JUN & JUL & AUG & SEP & $\mathrm{OCT}$ & Nov & DEC \\
\hline 1 & 1.61 & 1.03 & 1.40 & 3.05 & 1.23 & 38 & .23 & .096 & .072 & .11 & .13 & .20 \\
\hline 2 & 1.33 & .86 & 1.35 & 264 & 1.06 & .36 & .19 & .097 & .085 & .099 & .11 & .17 \\
\hline 3 & 1.12 & .75 & 1.46 & 237 & .95 & .34 & .18 & .098 & .17 & .099 & .099 & .16 \\
\hline 4 & 1.06 & .68 & 4.62 & 213 & 1.00 & .33 & .18 & .16 & .31 & .099 & .10 & 18.8 \\
\hline 5 & 1.85 & .64 & 3.88 & 222 & .85 & .31 & .18 & .15 & .14 & .099 & .35 & 8.65 \\
\hline 6 & 1.80 & .63 & 281 & 206 & .77 & .29 & .16 & .41 & .12 & $.094(\mathrm{e})$ & 20 & 276 \\
\hline 7 & 1.82 & .61 & 235 & 1.92 & .72 & .29 & .15 & .19 & .11 & $.088(e)$ & .14 & 1.83 \\
\hline 8 & 259 & .58 & 207 & 1.85 & .67 & .27 & .14 & .16 & .11 & $.092(e)$ & .11 & 1.36 \\
\hline 9 & 260 & .53 & 1.74 & 247 & .62 & .27 & .14 & .15 & .11 & $.11(e)$ & .11 & 1.00 \\
\hline 10 & 227 & .50 & 1.52 & 292 & .58 & .27 & .14 & .14 & .11 & $.10(e)$ & .11 & 1.89 \\
\hline 11 & 286 & .56 & 1.27 & 274 & .55 & .26 & .14 & .15 & .11 & $.10(e)$ & .11 & 1.82 \\
\hline 12 & 3.52 & .70 & 1.09 & 239 & .54 & .27 & .14 & .16 & .096 & $.10(e)$ & .11 & 1.54 \\
\hline 13 & 288 & .63 & 1.10 & 209 & .59 & 30 & .14 & .17 & .088 & .088 & .11 & 1.25 \\
\hline 14 & 233 & .60 & 1.01 & 1.84 & .56 & .36 & .15 & .16 & .088 & .088 & .20 & 1.06 \\
\hline 15 & 201 & .56 & .87 & 1.95 & .50 & .38 & .21 & .14 & .14 & .088 & .57 & .99 \\
\hline 16 & 1.75 & 1.37 & .98 & 202 & .46 & 29 & .17 & .13 & .14 & .11 & .28 & .82 \\
\hline 17 & 1.50 & 1.47 & 279 & 1.85 & .45 & $.26(\mathrm{e})$ & .22 & .11 & .13 & .11 & .31 & .72 \\
\hline 18 & 1.21 & 1.47 & 4.03 & 1.72 & .43 & $.25(\mathrm{e})$ & .19 & .21 & .11 & .11 & .27 & .66 \\
\hline 19 & 1.00 & 1.35 & 3.10 & 1.59 & .55 & $29(e)$ & .17 & $.13(e)$ & .11 & .099 & .22 & .59 \\
\hline 20 & .86 & 1.23 & 251 & 1.72 & .47 & $.25(e)$ & .16 & $.13(e)$ & .092 & .099 & .18 & .61 \\
\hline 21 & 99 & 5.34 & 215 & 207 & .48 & $.25(\mathrm{e})$ & .14 & $.12(e)$ & .088 & .19 & .15 & .98 \\
\hline 22 & .95 & 6.89 & 1.89 & 1.96 & .44 & $.23(e)$ & .13 & $.11(e)$ & .088 & .14 & .14 & 1.03 \\
\hline 23 & .90 & 3.66 & 18.0 & 1.88 & .40 & .21 & .13 & $.10(e)$ & .19 & .14 & .12 & .98 \\
\hline 24 & 266 & 260 & 11.6 & 1.70 & .38 & .20 & .12 & $.10(\mathrm{e})$ & .16 & .14 & .12 & .83 \\
\hline 25 & 3.44 & 2.17 & 6.15 & 1.56 & .37 & .19 & .11 & .11 & .17 & .13 & .11 & .76 \\
\hline 26 & 274 & 206 & 4.21 & 231 & .35 & .19 & .11 & .11 & 20 & .10 & .19 & .62 \\
\hline 27 & 2.25 & 1.79 & 7.64 & 1.99 & .33 & .18 & .13 & .095 & 32 & .088 & .46 & .52 \\
\hline 28 & 1.89 & 1.57 & 5.86 & 1.86 & .33 & .18 & .13 & .094 & .17 & .088 & 39 & .71 \\
\hline 29 & 1.56 & & 3.80 & 1.69 & 34 & .18 & .11 & .089 & .14 & .089 & 31 & 1.50 \\
\hline 30 & 1.27 & & 286 & 1.47 & .34 & .25 & .10 & .083 & .11 & .19 & .24 & 1.49 \\
\hline 31 & 1.12 & & 287 & & .47 & & .094 & .081 & & .16 & & $1.42(\mathrm{e})$ \\
\hline TOTAI & 57.7 & 428 & 108 & 620 & 17.8 & 8.08 & 4.70 & $4.23(e)$ & 4.09 & $3.44(e)$ & 6.08 & $57.7(\mathrm{e})$ \\
\hline MEAN & 1.86 & 1.53 & 3.51 & 207 & .57 & .27 & .15 & $.14(e)$ & .14 & $.11(e)$ & 20 & $1.86(\mathrm{c})$ \\
\hline MAX & 3.52 & 6.89 & 18.0 & 3.05 & 1.23 & .38 & .23 & .41 & .32 & .19 & .57 & 18.8 \\
\hline MWN & .86 & .50 & .87 & 1.47 & .33 & .18 & .094 & .081 & .072 & .088 & .099 & .16 \\
\hline $\begin{array}{l}\text { RUNOFF } \\
\text { (ii) }\end{array}$ & 268 & 1.99 & 5.06 & 38 & .11 & .05 & .22 & $.20(e)$ & .19 & $.16(e)$ & 28 & $268(e)$ \\
\hline
\end{tabular}

(c) - Estimated data. 
Table C5. Daily streamflow (cfs) at the East Seep monitoring station for the period January-December 1993

\begin{tabular}{|c|c|c|c|c|c|c|c|c|c|c|c|c|}
\hline DAY & JAN & FEB & MAR & APR & MAY & JUN & JUL & AUG & SEP & OCT & Nov & DEC \\
\hline 1 & .049 & .024 & .052 & .18 & .019 & .016 & $<.01$ & 0 & 0 & $<.01$ & $<.01$ & $<.01$ \\
\hline 2 & .043 & .019 & .054 & .089 & .017 & $<.01$ & $<.01$ & 0 & 0 & $<.01$ & $<.01$ & $<.01$ \\
\hline 3 & .040 & .019 & .086 & .064 & .016 & $<.01$ & $<.01$ & 0 & $<.01$ & $<.01$ & $<.01$ & $<.01$ \\
\hline 4 & .063 & .018 & .26 & .053 & .045 & $<.01$ & $<.01$ & $<.01$ & $<.01$ & $<.01$ & $<.01$ & 1.36 \\
\hline 5 & .12 & .019 & .099 & .085 & .015 & $<.01$ & 0 & $<.01$ & $<.01$ & $<.01$ & .047 & .27 \\
\hline 6 & .080 & .018 & .068 & .062 & .012 & $<.01$ & 0 & .049 & 0 & $<.01$ & $<.01$ & .059 \\
\hline 7 & .071 & .016 & .058 & .054 & .010 & $<.01$ & 0 & $<.01$ & 0 & $<.01$ & $<.01$ & .023 \\
\hline 8 & .17 & .016 & .049 & .045 & $<.01$ & $<.01$ & 0 & $<.01$ & 0 & $<.01$ & $<.01$ & .013 \\
\hline 9 & .095 & .016 & .038 & .17 & $<.01$ & $<.01$ & 0 & $<.01$ & 0 & $<.01$ & $<.01$ & .012 \\
\hline 10 & .069 & .016 & .035 & .11 & $<.01$ & $<.01$ & 0 & $<.01$ & 0 & $<.01$ & $<.01$ & .13 \\
\hline 11 & .18 & .043 & .030 & .069 & $<.01$ & $<.01$ & 0 & $<.01$ & 0 & $<.01$ & $<.01$ & .052 \\
\hline 12 & .14 & .049 & .035 & .053 & $<.01$ & $<.01$ & 0 & $<.01$ & 0 & $<.01$ & $<.01$ & .029 \\
\hline 13 & .084 & .032 & .050 & .046 & .043 & $<.01$ & $<.01$ & .013 & 0 & $<.01$ & $<.01$ & .020 \\
\hline 14 & .063 & .027 & .043 & .038 & .021 & .015 & $<.01$ & $<.01$ & 0 & $<.01$ & .037 & .030 \\
\hline 15 & .054 & .023 & .050 & .091 & .015 & .026 & $<.01$ & $<.01$ & $<.01$ & $<.01$ & .080 & .039 \\
\hline 16 & .048 & .12 & .082 & .078 & .012 & $<.01$ & .012 & $<.01$ & 0 & $<.01$ & .010 & .025 \\
\hline 17 & .038 & .067 & .26 & .058 & .010 & $<.01$ & $<.01$ & $<.01$ & 0 & $<.01$ & .016 & .019 \\
\hline 18 & .029 & .046 & .14 & .049 & .019 & $<.01$ & $<.01$ & .033 & 0 & $<.01$ & $<.01$ & .016 \\
\hline 19 & .024 & .036 & .082 & .045 & .085 & $<.01$ & $<.01$ & $<.01$ & 0 & 0 & $<.01$ & .014 \\
\hline 20 & .023 & .035 & .067 & .086 & .022 & $<.01$ & $<.01$ & $<.01$ & 0 & 0 & $<.01$ & .033 \\
\hline 21 & .062 & 30 & .059 & .077 & .024 & $<.01$ & $<.01$ & $<.01$ & 0 & $<.01$ & $<.01$ & .061 \\
\hline 22 & .039 & .15 & .054 & .049 & .017 & $<.01$ & $<.01$ & $<.01$ & 0 & $<.01$ & $<.01$ & .036 \\
\hline 23 & .033 & .075 & .69 & .033 & .013 & $<.01$ & $<.01$ & $<.01$ & .021 & $<.01$ & $<.01$ & .025 \\
\hline 24 & 31 & .058 & .21 & .030 & .010 & $<.01$ & $<.01$ & $<.01$ & $<.01$ & $<.01$ & $<.01$ & .019 \\
\hline 25 & .12 & .055 & .098 & .045 & .014 & $<.01$ & $<.01$ & $<.01$ & $<.01$ & $<.01$ & $<.01$ & .018 \\
\hline 26 & .067 & .083 & .11 & .13 & .013 & $<.01$ & 0 & 0 & $<.01$ & $<.01$ & .015 & .014 \\
\hline 27 & .051 & .068 & .29 & .052 & $<.01$ & $<.01$ & 0 & 0 & .030 & $<.01$ & .056 & .012 \\
\hline 28 & .040 & .059 & .13 & .036 & $<.01$ & $<.01$ & 0 & 0 & $<.01$ & $<.01$ & .021 & .055 \\
\hline 29 & .031 & & .082 & .027 & $<.01$ & $<.01$ & 0 & 0 & $<.01$ & $<.01$ & $<.01$ & .085 \\
\hline 30 & .026 & & .064 & .023 & $<.01$ & .018 & 0 & 0 & $<.01$ & .014 & $<.01$ & .044 \\
\hline 31 & .026 & & .17 & & .049 & & 0 & 0 & & $<.01$ & & .029 \\
\hline TOTAL & 230 & 1.51 & 3.59 & 202 & .56 & .13 & .041 & .14 & .087 & .061 & .36 & 256 \\
\hline MEAN & .074 & .054 & .12 & .067 & .018 & $<.01$ & $<.01$ & $<.01$ & $<.01$ & $<.01$ & .012 & .083 \\
\hline MAX & 31 & 30 & .69 & .18 & .085 & .026 & .012 & .049 & .030 & .014 & .080 & 1.36 \\
\hline $\mathbf{M m}$ & .023 & .016 & .030 & .023 & $<.01$ & $<.01$ & 0 & 0 & 0 & 0 & $<.01$ & $<.01$ \\
\hline $\begin{array}{l}\text { RUNOFP } \\
\text { (in) }\end{array}$ & 285 & 1.88 & 4.45 & 251 & .70 & .16 & .05 & .16 & .10 & .07 & .42 & 298 \\
\hline
\end{tabular}


Table C.6. Daily streamflow (cfs) at the West Seep monitoring station for the period January-December 1993

\begin{tabular}{|c|c|c|c|c|c|c|c|c|c|c|c|c|}
\hline DAY & JAN & FEB & MAR & APR & MAY & JUN & JUL & AUG & SEP & OCT & NOV & DEC \\
\hline 1 & .30 & .18 & .41 & 1.82 & .37 & .12 & .072 & 0 & $.010(e)$ & .016 & .055 & .073 \\
\hline 2 & .26 & .16 & .43 & .93 & .36 & .069 & 27 & 0 & .016 & .019 & .045 & .066 \\
\hline 3 & .23 & .15 & .66 & .63 & .36 & .053 & .019 & 0 & .055 & .025 & .043 & .065 \\
\hline 4 & 36 & .14 & 3.14 & .49 & .47 & .048 & .015 & .059 & .18 & .020 & .041 & 16.0 \\
\hline 5 & 1.27 & .13 & 1.10 & .82 & .33 & .040 & .013 & .014 & .048 & .016 & .37 & 277 \\
\hline 6 & .70 & .13 & .65 & .70 & .31 & .034 & .011 & .40 & .033 & .015 & .13 & .60 \\
\hline 7 & so & .13 & .49 & .56 & .31 & .033 & $<.01$ & .037 & .022 & .012 & .059 & .28 \\
\hline 8 & 1.66 & .12 & .40 & .47 & .30 & .029 & $<.01$ & .017 & .019 & .015 & .041 & .19 \\
\hline 9 & .92 & .12 & 32 & 1.87 & .29 & .026 & $<.01$ & .012 & .021 & .033 & .032 & .15 \\
\hline 10 & .55 & .12 & .31 & 1.57 & .29 & .024 & $<.01$ & .010 & .019 & .029 & .030 & 1.49 \\
\hline 11 & 1.68 & .26 & .28 & .81 & .29 & .022 & $<.01$ & .026 & .011 & .020 & .027 & .67 \\
\hline 12 & 1.41 & .38 & 28 & .54 & .29 & .024 & $<.01$ & .084 & .010 & .019 & .024 & .35 \\
\hline 13 & .76 & 25 & .36 & .44 & .37 & .061 & .011 & .12 & $<.01$ & .016 & .024 & .25 \\
\hline 14 & .49 & .21 & 31 & .40 & .17 & .069 & .014 & .042 & .011 & .020 & .23 & .29 \\
\hline 15 & .40 & .19 & .35 & 1.20 & .16 & .23 & .039 & .020 & .023 & .024 & .82 & .45 \\
\hline 16 & .35 & 1.38 & .66 & 1.81 & .16 & .047 & .018 & .014 & .031 & .038 & .19 & .34 \\
\hline 17 & .28 & .74 & 3.29 & 1.35 & .11 & .033 & .094 & .012 & .024 & .041 & .18 & .26 \\
\hline 18 & .22 & .45 & 1.75 & 1.17 & .10 & .026 & .026 & .25 & .015 & .040 & .14 & .22 \\
\hline 19 & .19 & 35 & .88 & 1.06 & .49 & .042 & .017 & .031 & .012 & .020 & .11 & .18 \\
\hline 20 & .17 & 29 & .61 & 1.49 & .14 & .024 & .013 & .109 & $<.01$ & .020 & .081 & .31 \\
\hline 21 & .43 & 3.25 & .49 & 1.82 & .16 & .030 & $<.01$ & .016 & .011 & .15 & .055 & .83 \\
\hline 22 & .34 & 1.76 & .43 & 1.35 & .12 & .028 & $<.01$ & .016 & $<.01$ & .071 & .043 & .48 \\
\hline 23 & .30 & $\pi$ & 9.21 & 1.12 & .090 & .019 & $<.01$ & $<.01$ & .16 & .038 & .043 & .32 \\
\hline 24 & 3.23 & .48 & 259 & 1.00 & .071 & .018 & $<.01$ & $.010(e)$ & .044 & .036 & .043 & .24 \\
\hline 25 & 1.27 & .41 & 1.04 & 1.03 & .093 & .018 & $<.01$ & $.010(c)$ & .080 & .036 & .039 & .20 \\
\hline 26 & .64 & .60 & .91 & 226 & .096 & .017 & $<.01$ & $.010(e)$ & .097 & .034 & .12 & .16 \\
\hline 27 & .43 & .60 & 3.31 & 1.23 & .063 & .013 & $<.01$ & $.010(e)$ & .25 & .030 & .54 & .14 \\
\hline 28 & .32 & .50 & 1.44 & .67 & .053 & .012 & $<.01$ & $.010(\mathrm{e})$ & .041 & .031 & .31 & .56 \\
\hline 29 & .25 & & .79 & .41 & .050 & .021 & $<.01$ & $.010(e)$ & .023 & .031 & .16 & 1.27 \\
\hline 30 & .21 & & .52 & .38 & .056 & .13 & 0 & $.010(c)$ & .016 & .16 & .10 & .57 \\
\hline 31 & .19 & & 1.34 & & .25 & & 0 & $.010(\mathrm{c})$ & & .10 & & 36 \\
\hline TOTAL & 20.3 & 14.2 & 38.8 & 31.4 & 6.79 & 1.36 & .45 & $1.30(\mathrm{e})$ & $1.31(\mathrm{c})$ & 1.18 & 4.12 & 30.2 \\
\hline MEAN & .65 & .51 & 1.25 & 1.05 & .22 & .045 & .015 & $.042(\mathrm{c})$ & $.044(\mathrm{e})$ & .038 & .14 & .97 \\
\hline MAX & 3.23 & 3.25 & 9.21 & 2.26 & .49 & .23 & .094 & 40 & 25 & .16 & .82 & 16.0 \\
\hline MIN & .17 & .12 & .28 & 38 & .050 & .012 & 0 & 0 & $<.01$ & .012 & .024 & .065 \\
\hline $\begin{array}{l}\text { RUNOFF } \\
\text { (ii) }\end{array}$ & 3.02 & 212 & 5.77 & 4.67 & 1.01 & .20 & .07 & $.19(e)$ & $.19(e)$ & .18 & .61 & 4.49 \\
\hline
\end{tabular}

(c) - Extimated data. 
Table C.7. Daily streamflow (cfs) at the Raccoon Creek monitoring station for the period January-December 1993

\begin{tabular}{|c|c|c|c|c|c|c|c|c|c|c|c|c|}
\hline DAY & JAN & FEB & MAR & APR & MAY & JUN & JUL & AUG & SEP & OCT & Nov & DEC \\
\hline 1 & .14 & .091 & .26 & .99 & .078 & .051 & .053 & $.010(\mathrm{e})$ & $<.01$ & $<.01$ & .022 & .028 \\
\hline 2 & .12 & .065 & .29 & .46 & .066 & .029 & .015 & $.010(c)$ & $<.01$ & $<.01$ & .016 & .024 \\
\hline 3 & .11 & .052 & .68 & .26 & .064 & .026 & .012 & $.010(e)$ & .015 & .019 & .011 & .022 \\
\hline 4 & .18 & .049 & 3.28 & .18 & .18 & .022 & .012 & $.020(\mathrm{c})$ & .13 & .023 & $<.01$ & 16.7 \\
\hline 5 & .67 & .047 & .71 & .60 & .076 & .031 & .014 & $.060(e)$ & .011 & .010 & .29 & 3.49 \\
\hline 6 & .38 & .046 & .36 & .32 & .086 & .034 & $<.01$ & $.060(e)$ & .018 & $<.01$ & .050 & 1.65 \\
\hline 7 & .24 & .043 & 22 & .20 & .062 & .037 & $<.01$ & $.030(e)$ & .020 & $<.01$ & .025 & .43 \\
\hline 8 & 1.64 & .040 & .17 & .16 & .047 & .033 & $<.01$ & $.020(\mathrm{e})$ & $<.01$ & $<.01$ & .017 & .12 \\
\hline 9 & .53 & .036 & .12 & 1.85 & .041 & .013 & $<.01$ & $.010(e)$ & $<.01$ & $<.01$ & .014 & .063 \\
\hline 10 & .28 & .035 & .092 & .79 & .036 & .016 & .011 & $.010(\mathrm{e})$ & $<.01$ & .013 & .012 & 1.44 \\
\hline 11 & 231 & .14 & .070 & .38 & .033 & .022 & .012 & $.010(e)$ & $<.01$ & .028 & .014 & .31 \\
\hline 12 & .98 & 34 & .063 & .26 & .031 & .020 & .012 & .013 & $<.01$ & .022 & .012 & .15 \\
\hline 13 & .52 & .12 & .12 & .17 & .046 & .030 & .011 & .030 & $<.01$ & .012 & $<.01$ & .096 \\
\hline 14 & .27 & .093 & .12 & .12 & .052 & .028 & $<.01$ & .018 & $<.01$ & $<.01$ & .19 & .13 \\
\hline 15 & .19 & .086 & .16 & .68 & .035 & .074 & .013 & .011 & $<.01$ & $<.01$ & .84 & .25 \\
\hline 16 & .15 & 1.37 & .43 & .44 & .028 & .021 & .012 & $<.01$ & $<.01$ & .014 & .094 & .13 \\
\hline 17 & .12 & 30 & 255 & .19 & .024 & .017 & $<.01$ & $<.01$ & $<.01$ & .012 & .11 & .085 \\
\hline 18 & .090 & .18 & 1.22 & .13 & .024 & .013 & $<.01$ & .072 & $<.01$ & .013 & .076 & .066 \\
\hline 19 & .077 & .13 & .65 & .10 & .19 & .013 & $<.01$ & .016 & $<.01$ & .015 & .045 & .055 \\
\hline 20 & .070 & .12 & .41 & .64 & .043 & .015 & $<.01$ & .011 & $<.01$ & .010 & .032 & .16 \\
\hline 21 & 39 & 4.54 & 32 & .51 & .040 & .025 & $<.01$ & .013 & $<.01$ & .075 & .025 & .57 \\
\hline 22 & .20 & 1.35 & .24 & .21 & .034 & .024 & $<.01$ & $<.01$ & $<.01$ & .026 & .02 & .17 \\
\hline 23 & .12 & .58 & 10.5 & .15 & .025 & .010 & $<.01$ & .011 & .067 & .016 & .023 & .10 \\
\hline 24 & 3.18 & 35 & 226 & .11 & .020 & $<.01$ & $<.01$ & .012 & .017 & .010 & .017 & .076 \\
\hline 25 & .78 & 29 & 81 & .12 & .020 & .018 & $<.01$ & $<.01$ & .013 & .010 & .014 & .064 \\
\hline 26 & .39 & .49 & .78 & 1.32 & .022 & .025 & $<.01$ & $<.01$ & .023 & $<.01$ & .046 & .049 \\
\hline 27 & 23 & .44 & 3.43 & .23 & .016 & .029 & $<.01$ & $<.01$ & .16 & $<.01$ & .47 & .044 \\
\hline 28 & .16 & .30 & 1.14 & .15 & .017 & .034 & $<.01$ & $<.01$ & .021 & $<.01$ & .15 & .57 \\
\hline 29 & .12 & & .63 & .11 & .016 & .029 & $<.01$ & $<.01$ & .013 & $<.01$ & .061 & .79 \\
\hline 30 & .098 & & 35 & .093 & .020 & .12 & $<.01$ & $<.01$ & $<.01$ & .063 & .038 & .21 \\
\hline 31 & .093 & & 1.10 & & .082 & . & $.010(c)$ & $<.01$ & & .029 & & .13 \\
\hline TOTAL & 14.8 & 11.7 & 33.6 & 11.9 & 1.55 & .86 & $31(e)$ & $S 1(e)$ & .61 & .50 & 276 & 28.2 \\
\hline MEAN & .48 & .42 & 1.08 & .40 & .050 & .029 & $.010(e)$ & $.017(\theta)$ & .020 & .016 & .092 & .91 \\
\hline MAX & 3.18 & 4.54 & 10.5 & 1.85 & .19 & .12 & .053 & .072 & .16 & .075 & .84 & 16.7 \\
\hline $\mathbf{M N N}$ & .070 & .035 & .063 & .093 & .016 & $<.01$ & $<.01$ & $<.01$ & $<.01$ & $<.01$ & $<.01$ & .022 \\
\hline $\begin{array}{l}\text { RUNOFF } \\
\text { (ii) }\end{array}$ & 1.67 & 1.32 & 3.79 & 1.34 & .17 & .10 & $.04(\mathrm{c})$ & $.06(0)$ & .07 & .06 & 31 & 3.17 \\
\hline
\end{tabular}


Table C.8. Daily streamflow (cfs) at the Ish Creek monitoring station for the period January-February 1993

\begin{tabular}{|c|c|c|}
\hline DAY & JAN & FEB $^{1}$ \\
\hline 1 & 1.44 & .86 \\
\hline 2 & 1.02 & .65 \\
\hline 3 & .86 & .57 \\
\hline 4 & 1.04 & .53 \\
\hline 5 & 3.41 & .50 \\
\hline 6 & 263 & .49 \\
\hline 7 & 229 & .47 \\
\hline 8 & 3.52 & .44 \\
\hline 9 & 3.06 & .40 \\
\hline 10 & 239 & 37 \\
\hline 11 & 3.65 & .52 \\
\hline 12 & 4.06 & 1.15 \\
\hline 13 & 3.07 & .67 \\
\hline 14 & 234 & 56 \\
\hline 15 & 201 & .51 \\
\hline 16 & 1.68 & 262 \\
\hline 17 & 1.27 & 226 \\
\hline 18 & .90 & 1.93 \\
\hline 19 & .73 & 1.57 \\
\hline 20 & .65 & 1.36 \\
\hline 21 & 1.21 & 6.27 \\
\hline 22 & 1.02 & 6.11 \\
\hline 23 & .85 & 3.59 \\
\hline 24 & 4.67 & 254 \\
\hline 25 & 4.28 & 216 \\
\hline 26 & 297 & 215 \\
\hline 27 & 231 & 1.90 \\
\hline 28 & 1.88 & 1.63 \\
\hline 29 & 1.42 & \\
\hline 30 & .97 & \\
\hline 31 & .90 & \\
\hline TOTAL & 64.5 & 44.8 \\
\hline MEAN & 208 & 1.50 \\
\hline MAX & 4.67 & 6.27 \\
\hline MIN & .65 & .37 \\
\hline RUNOFF (in) & 252 & 1.75 \\
\hline
\end{tabular}

'Monitoring station was not accessible after February 28, 1993 
Table C.9. Daily streamflow (cfs) at monitoring station Walker Branch East weir (WBE) for the period January-December 1993

\begin{tabular}{|c|c|c|c|c|c|c|c|c|c|c|c|c|}
\hline DAY & JAN & FEB & MAR & APR & MAY & JUN & JUL & AUG & SEP & $\mathrm{OCT}$ & Nov & DEC \\
\hline 1 & .43 & .19 & .36 & .66 & .34 & .10 & .04 & $<.01$ & 0 & $<.01$ & $<.01$ & .02 \\
\hline 2 & .34 & .15 & .36 & .62 & .27 & .08 & .03 & 0 & 0 & $<.01$ & $<.01$ & .01 \\
\hline 3 & .27 & .11 & .37 & .58 & .22 & .06 & .03 & $<.01$ & $<.01$ & $<.01$ & $<.01$ & .01 \\
\hline 4 & .24 & .10 & 1.33 & .54 & 23 & .06 & .03 & $<.01$ & .04 & $<.01$ & $<.01$ & 4.20 \\
\hline 5 & .25 & .10 & 1.24 & .54 & .19 & .06 & .03 & $<.01$ & $<.01$ & $<.01$ & .07 & 211 \\
\hline 6. & .35 & .10 & .79 & .49 & .17 & .06 & .03 & .06 & 0 & $<.01$ & .07 & .60 \\
\hline 7 & .41 & .09 & .61 & .49 & .15 & .05 & .03 & .01 & 0 & 0 & .03 & .35 \\
\hline 8 & .58 & .08 & .50 & .48 & .15 & .05 & .03 & $<.01$ & 0 & $<.01$ & .02 & 22 \\
\hline 9 & .89 & .07 & .40 & .59 & .13 & .05 & .03 & $<.01$ & 0 & $<.01$ & .01 & .10 \\
\hline 10 & .78 & .06 & 35 & 1.06 & .15 & .06 & .03 & $<.01$ & 0 & $<.01$ & $<.01$ & .21 \\
\hline 11 & .71 & .07 & 32 & .91 & .15 & .07 & .04 & $<.01$ & 0 & $<.01$ & $<.01$ & .41 \\
\hline 12 & 1.22 & .11 & .24 & .72 & .13 & .05 & .04 & .01 & 0 & $<.01$ & $<.01$ & .38 \\
\hline 13 & 1.05 & .11 & .25 & 59 & .13 & .08 & .04 & .02 & 0 & $<.01$ & .01 & .30 \\
\hline 14 & .75 & .11 & 22 & .48 & .13 & .10 & .05 & .02 & 0 & $<.01$ & .02 & .20 \\
\hline 15 & .58 & .11 & .16 & .46 & .12 & .07 & .04 & .01 & .01 & 0 & .12 & .13 \\
\hline 16 & .47 & 25 & .17 & .49 & .11 & .04 & .02 & $<.01$ & .02 & $<.01$ & .15 & .10 \\
\hline 17 & 37 & .52 & .95 & .50 & .12 & .04 & .02 & $<.01$ & .02 & $<.01$ & .08 & .09 \\
\hline 18 & .26 & .47 & 1.48 & .51 & .10 & .03 & .02 & .02 & .01 & $<.01$ & .04 & .09 \\
\hline 19 & .17 & .39 & .94 & .48 & .14 & .05 & .03 & .01 & $<.01$ & $<.01$ & .04 & .08 \\
\hline 20 & .13 & .34 & .68 & .44 & .10 & .04 & .04 & $<.01$ & $<.01$ & $<.01$ & .02 & .09 \\
\hline 21 & .14 & 1.88 & .53 & .57 & .09 & .05 & .02 & $<.01$ & 0 & .04 & .01 & .15 \\
\hline 22 & .15 & 260 & .44 & .69 & .08 & .05 & .02 & $<.01$ & 0 & .03 & .01 & .21 \\
\hline 23 & .15 & 1.17 & 4.70 & 59 & .08 & .04 & .02 & $<.01$ & .02 & $<.01$ & $<.01$ & .23 \\
\hline 24 & .69 & .71 & 3.46 & so & .07 & .04 & .02 & 0 & .01 & $<.01$ & $<.01$ & 21 \\
\hline 25 & 1.26 & .53 & 1.63 & .42 & .08 & .03 & .02 & $<.01$ & .01 & $<.01$ & $<.01$ & .15 \\
\hline 26 & .82 & .44 & 1.07 & .56 & .07 & .03 & .02 & $<.01$ & .04 & $<.01$ & .01 & .09 \\
\hline 27 & .58 & .38 & 1.76 & .64 & .07 & .03 & .04 & 0 & .09 & $<.01$ & .08 & .07 \\
\hline 28 & .43 & .36 & 1.72 & .56 & .07 & .02 & .03 & $<.01$ & .01 & $<.01$ & .11 & .09 \\
\hline 29 & 35 & & 1.11 & .47 & .07 & .02 & .03 & $<.01$ & $<.01$ & $<.01$ & .06 & .25 \\
\hline 30 & .26 & & .79 & .40 & .08 & .03 & .01 & 0 & $<.01$ & .03 & .03 & .45 \\
\hline 31 & 20 & & .70 & & .12 & & $<.01$ & 0 & & .02 & & .38 \\
\hline TOTAL & 15.25 & 11.58 & 29.63 & 17.02 & 4.10 & 1.54 & .84 & 22 & .30 & .16 & 1.06 & 11.97 \\
\hline MEAN & .49 & .41 & .96 & 57 & .13 & .05 & .03 & .01 & .01 & .01 & .04 & .39 \\
\hline MAX & 1.26 & 260 & 4.70 & 1.06 & 34 & .10 & .05 & .06 & .09 & .04 & .15 & 4.20 \\
\hline MIN & .13 & .06 & .16 & .40 & .07 & .02 & $<.01$ & 0 & 0 & 0 & 0 & .01 \\
\hline $\begin{array}{l}\text { RUNOFF } \\
\text { (iv) }\end{array}$ & 247 & 1.87 & 4.79 & 275 & .66 & .25 & .14 & .03 & .05 & .03 & .17 & 1.94 \\
\hline
\end{tabular}


Table C.10. Daily streamflow (cfs) at monitoring station Walker Branch West weir (WBW) for the period January-December 1993

\begin{tabular}{|c|c|c|c|c|c|c|c|c|c|c|c|c|}
\hline DAY & JAN & FEB & MAR & APR & MAY & JUN & JUL & AUG & SEP & OCT & Nov & DEC \\
\hline 1 & so & .35 & .49 & .77 & .46 & .24 & .20 & .16 & .15 & .15 & .15 & .15 \\
\hline 2 & .42 & .29 & .49 & .73 & .41 & .23 & .19 & .16 & .15 & .16 & .15 & .15 \\
\hline 3 & .36 & .26 & .49 & .70 & 39 & .23 & .19 & .18 & .18 & .19 & .15 & .15 \\
\hline 4 & 36 & .25 & 1.12 & .66 & .38 & .23 & .19 & .23 & .18 & .18 & .18 & 266 \\
\hline 5 & .47 & .25 & 1.20 & .66 & .34 & 22 & .19 & .26 & .16 & .18 & .23 & 1.69 \\
\hline 6 & 52 & .25 & 90 & .63 & 32 & .21 & .18 & .24 & .16 & .17 & .20 & .73 \\
\hline 7 & .55 & .25 & .75 & .63 & .32 & .21 & .18 & .17 & .15 & .15 & .20 & .44 \\
\hline 8 & .74 & 24 & .63 & .60 & .31 & .21 & .18 & .16 & .15 & .15 & .20 & .31 \\
\hline 9 & .81 & .23 & .52 & .69 & .29 & .21 & .18 & .16 & .15 & .16 & .20 & .21 \\
\hline 10 & .78 & 22 & .47 & .95 & .29 & .21 & .18 & .16 & .15 & .15 & .20 & .37 \\
\hline 11 & .85 & 25 & .40 & .96 & .29 & .21 & .18 & .17 & .15 & .15 & .20 & .47 \\
\hline 12 & 1.06 & .27 & 36 & .82 & .29 & .21 & .18 & .17 & .15 & .15 & .20 & .42 \\
\hline 13 & .94 & .25 & .41 & .70 & .30 & .22 & .18 & .18 & .15 & .15 & .20 & .35 \\
\hline 14 & .73 & .25 & .34 & .61 & .28 & 22 & .18 & .16 & .15 & .15 & .23 & .28 \\
\hline 15 & .61 & .25 & .30 & .64 & 27 & .22 & .19 & .16 & .17 & .15 & .25 & .24 \\
\hline 16 & .53 & .43 & .35 & .71 & .27 & .21 & .18 & .16 & .16 & .15 & .21 & .23 \\
\hline 17 & .44 & .55 & .87 & .71 & .27 & .21 & .19 & .16 & .15 & .15 & .21 & .21 \\
\hline 18 & .34 & .57 & 1.28 & .64 & .27 & .20 & .18 & .18 & .15 & .15 & .20 & .21 \\
\hline 19 & .30 & .49 & .96 & 56 & .29 & 22 & .19 & .16 & .15 & .15 & .20 & .20 \\
\hline 20 & .27 & .45 & .78 & 56 & .26 & .20 & .18 & .16 & .15 & .15 & .19 & 21 \\
\hline 21 & 31 & 1.30 & .64 & .67 & .25 & .20 & .18 & .16 & .15 & .17 & .19 & 29 \\
\hline 22 & 32 & 1.98 & .56 & .73 & 25 & .20 & .18 & .16 & .15 & .16 & .16 & .34 \\
\hline 23 & 32 & 1.18 & 3.04 & .70 & .25 & .20 & .17 & .16 & .18 & .15 & .13 & .32 \\
\hline 24 & .66 & .87 & 272 & .61 & .25 & .20 & .17 & .16 & .15 & .15 & .13 & .28 \\
\hline 25 & 1.15 & .70 & 1.54 & .56 & .25 & .20 & .18 & .16 & .16 & .15 & .13 & .26 \\
\hline 26 & 90 & 59 & 1.17 & .65 & .28 & .20 & .17 & .17 & .17 & .15 & .15 & .20 \\
\hline 27 & .71 & 51 & 1.56 & .67 & .33 & .20 & .21 & .16 & .18 & .15 & .18 & .19 \\
\hline 28 & .57 & 50 & 1.55 & .65 & .29 & .20 & .18 & .16 & .15 & .16 & .17 & 22 \\
\hline 29 & .47 & & 1.17 & .59 & 24 & .20 & .17 & .16 & .15 & .15 & .15 & .41 \\
\hline 30 & 38 & & .95 & .53 & .23 & .20 & .17 & .15 & .15 & .16 & .15 & .47 \\
\hline 31 & .36 & & .84 & & .27 & & .17 & .15 & & .15 & & .45 \\
\hline TOTAL & 17.73 & 13.95 & 28.81 & 20.27 & 9.18 & 6.32 & 5.61 & 5.30 & 4.66 & 4.80 & 5.47 & 13.10 \\
\hline MEAN & .57 & .50 & .93 & .67 & 30 & .21 & .18 & .17 & .16 & .16 & .18 & .42 \\
\hline MAX & 1.15 & 1.98 & 3.04 & .96 & .46 & .24 & .21 & .26 & .18 & .19 & .25 & 266 \\
\hline $\mathrm{MmN}$ & .27 & .22 & .30 & .53 & .23 & .20 & .17 & .15 & .15 & .15 & .13 & .15 \\
\hline $\begin{array}{l}\text { RUNOFF } \\
\text { (in) }\end{array}$ & 4.40 & 3.47 & 7.14 & 5.03 & 228 & 1.57 & 1.40 & 1.32 & 1.16 & 1.20 & 1.36 & 3.25 \\
\hline
\end{tabular}


Table C.11. Daily streamflow (cfs) at monitoring station GS1 (USGS 03536450) for the period January-December 1993

\begin{tabular}{|c|c|c|c|c|c|c|c|c|c|c|c|c|}
\hline DAY & JAN & FEB & MAR & APR & MAY & JUN & JUL & AUG & SEP & OCT & Nov & DEC \\
\hline 1 & 1.1 & .77 & 1.1 & 21 & .95 & .33 & .41 & .18 & .17 & 30 & .30 & .30 \\
\hline 2 & .88 & .67 & 1.2 & 1.8 & .84 & .31 & .33 & .20 & .18 & 32 & .28 & 28 \\
\hline 3 & .73 & .56 & 1.7 & 1.6 & .75 & 31 & .28 & .19 & .54 & .27 & 30 & .29 \\
\hline 4 & .85 & .53 & 3.4 & 1.4 & 1.0 & .30 & .26 & 57 & 1.4 & .26 & 36 & 13 \\
\hline 5 & 1.9 & 52 & 22 & 1.9 & .69 & .28 & .25 & .24 & .54 & .27 & 1.2 & 4.4 \\
\hline 6 & 1.4 & 52 & 1.8 & 1.5 & .63 & .26 & .24 & 1.7 & .49 & .26 & .48 & 21 \\
\hline 7 & 1.5 & .49 & 1.6 & 1.3 & .60 & .27 & .24 & 38 & .41 & 25 & 38 & 1.3 \\
\hline 8 & 25 & .47 & 1.3 & 1.3 & 56 & .27 & .58 & .30 & 25 & .25 & .33 & .96 \\
\hline 9 & 1.8 & .43 & 1.2 & 28 & .52 & .25 & 22 & 25 & 23 & .37 & 30 & .70 \\
\hline 10 & 1.6 & .41 & 1.1 & 21 & .47 & .24 & 22 & 20 & .17 & .25 & .28 & 24 \\
\hline 11 & 25 & .77 & .91 & 1.8 & .43 & .33 & .23 & .25 & .15 & .28 & .27 & 1.3 \\
\hline 12 & 22 & .73 & .85 & 1.6 & .41 & .52 & .23 & .27 & .15 & .25 & .26 & 1.1 \\
\hline 13 & 1.9 & $.56(\mathrm{e})$ & .99 & 1.4 & .56 & .58 & .23 & .36 & .16 & .24 & 25 & .83 \\
\hline 14 & 1.6 & $52(\theta)$ & .97 & 1.3 & .42 & .54 & 22 & .21 & .20 & .25 & 1.8 & .81 \\
\hline 15 & 1.4 & $.50(e)$ & .92 & 20 & .39 & .94 & .48 & .20 & .40 & .24 & .75 & .80 \\
\hline 16 & 1.2 & $1.7(\mathrm{c})$ & 1.4 & 1.5 & 37 & .58 & .25 & .19 & .30 & 30 & .62 & .63 \\
\hline 17 & 1.0 & 1.2 & 29 & 1.3 & 35 & 57 & .51 & .19 & .28 & .25 & .67 & 54 \\
\hline 18 & .78 & 1.2 & 24 & 1.2 & .41 & .47 & .27 & .40 & .25 & .25 & $.43(e)$ & so \\
\hline 19 & .63 & 1.1 & 21 & 1.2 & .77 & 39 & .26 & 20 & .24 & .25 & $.38(e)$ & .44 \\
\hline 20 & .60 & .99 & 1.8 & 1.9 & .38 & .25 & .24 & .20 & .24 & 26 & .34 & .81 \\
\hline 21 & 1.1 & $S .0$ & 1.5 & 1.5 & .43 & .26 & .24 & .18 & .25 & .72 & 29 & 1.1 \\
\hline 22 & .79 & 3.0 & 1.3 & 1.4 & .34 & .25 & .23 & .18 & .23 & .32 & .26 & .91 \\
\hline 23 & .73 & 22 & 10 & 1.3 & 33 & .24 & 20 & .18 & 1.0 & .28 & .25 & .80 \\
\hline 24 & 22 & 1.7 & 5.5 & 1.2 & .33 & .25 & .21 & .18 & 39 & 28 & 23 & .67 \\
\hline 25 & 21 & 1.6 & 3.1 & 1.4 & 34 & .25 & .21 & .18 & 52 & .28 & 23 & .61 \\
\hline 26 & 1.8 & 1.7 & 29 & 23 & 34 & .24 & .21 & .17 & .53 & .27 & 53 & 50 \\
\hline 27 & 1.6 & 1.3 & 4.4 & 1.4 & 32 & 23 & .20 & .17 & .99 & .34 & 1.0 & .42 \\
\hline 28 & 1.4 & 1.2 & 29 & 1.3 & 32 & .24 & .19 & .17 & .48 & .25 & .58 & 1.3 \\
\hline 29 & 1.2 & & 23 & 1.2 & 31 & 23 & .20 & .17 & .40 & .27 & .43 & 1.5 \\
\hline 30 & .95 & & 1.9 & 1.1 & 30 & .97 & .19 & .17 & .34 & .64 & 35 & 1.2 \\
\hline 31 & .81 & & 27 & & .57 & & .18 & .17 & & 34 & & 1.0 \\
\hline TOTAL & 4275 & 3234 & 70.34 & 47.1 & 15.43 & 11.15 & 8.23 & 8.60 & 11.88 & 9.36 & 14.13 & 43.50 \\
\hline MEAN & 1.38 & 1.15 & 227 & 1.57 & 50 & .37 & 27 & 28 & .40 & 30 & .47 & 1.40 \\
\hline MAX & 25 & 5.0 & 10 & 28 & 1.0 & .97 & .58 & 1.7 & 1.4 & .72 & 1.8 & 13 \\
\hline MIN & .60 & .41 & .85 & 1.1 & 30 & .23 & .18 & .17 & .15 & .24 & 23 & 28 \\
\hline $\begin{array}{l}\text { RUNOFF } \\
\text { (in) }\end{array}$ & 4.82 & 0.25 & 10.47 & 5.31 & 1.75 & 1.25 & .96 & .96 & 1.32 & 1.05 & 1.59 & 4.89 \\
\hline
\end{tabular}

(c) - Extimated data 
Table C.12 Daily streamflow (cfs) at monitoring station GS2 (USGS 03537100) for the period January-December 1993

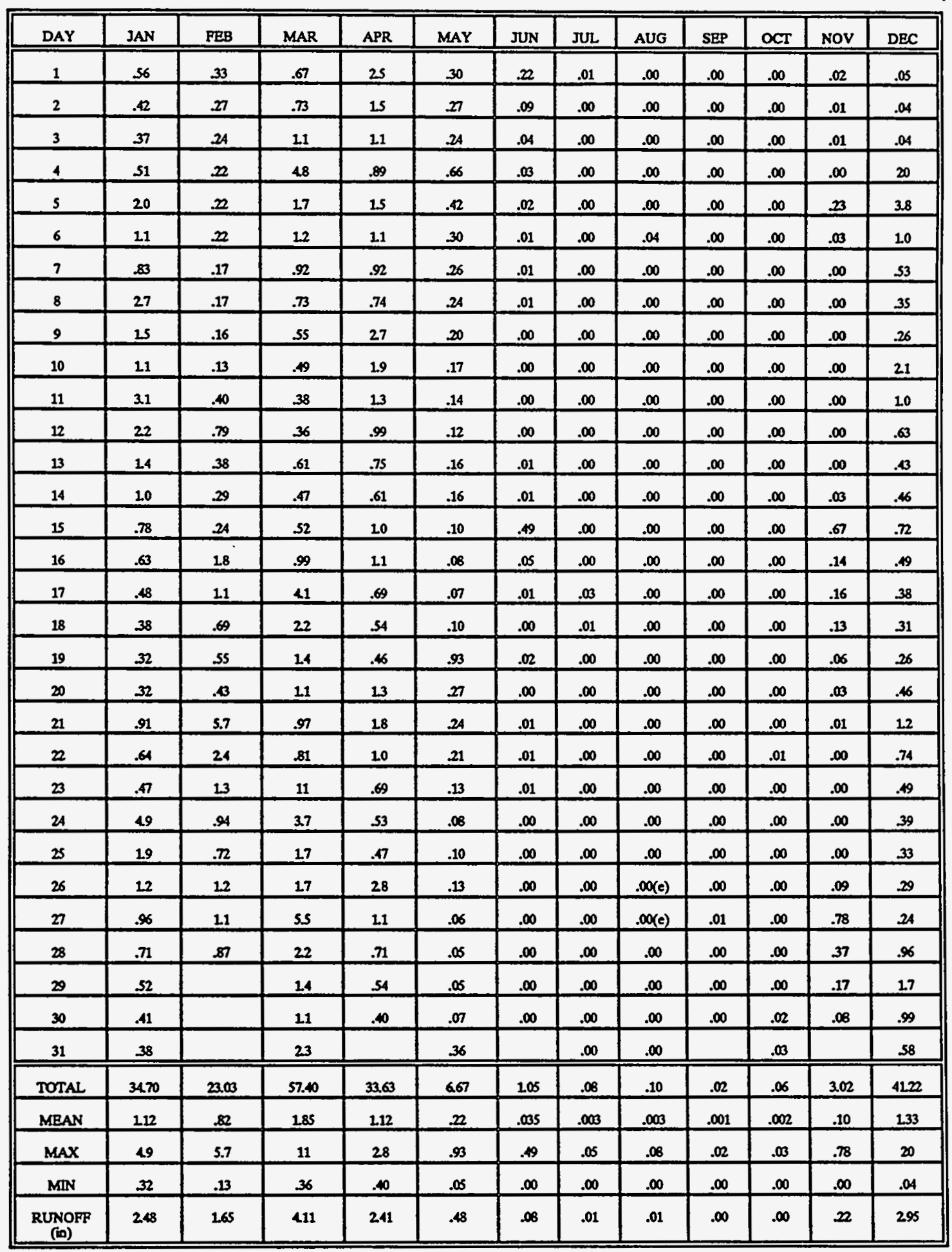

(c) - Estionated data 
Table C.13. Daily streamflow (cfs) at monitoring station GS3 (USGS 03536550) for the period January-December 1993

\begin{tabular}{|c|c|c|c|c|c|c|c|c|c|c|c|c|}
\hline DAY & JAN & FEB & MAR & APR & MAY & JUN & JUL & AUG & SEP & OCT & Nov & DEC \\
\hline 1 & 9.5 & 7.3 & 9.6 & 21 & 8.7 & 5.4 & 7.1 & 4.5 & 5.1 & 4.3 & 4.7 & 5.2 \\
\hline 2 & 7.9 & 6.8 & 10 & 17 & 7.7 & 5.2 & 5.9 & 5.0 & 5.6 & 4.7 & 4.3 & 4.8 \\
\hline 3 & 7.4 & 6.5 & 14 & 14 & 7.2 & 5.3 & 5.5 & 5.2 & 7.4 & 4.3 & 4.5 & 5.0 \\
\hline 4 & 11 & 6.2 & 34 & 13 & 11 & 5.6 & 5.3 & 8.2 & 10 & 4.1 & 5.3 & 116 \\
\hline 5 & 18 & 6.2 & 20 & 17 & 7.4 & 5.2 & 5.2 & 5.4 & 4.9 & 4.1 & 12 & 38 \\
\hline 6 & 12 & 5.8 & 15 & 13 & 6.9 & 4.7 & 5.0 & 16 & 4.6 & 4.2 & 59 & 16 \\
\hline 7 & 12 & 5.8 & 13 & 12 & 6.7 & 5.3 & 5.2 & 6.2 & 4.8 & 4.3 & 5.2 & 11 \\
\hline 8 & 22 & 5.8 & 11 & 11 & 6.4 & 5.3 & 7.0 & 5.6 & 5.0 & 4.4 & 4.6 & 8.9 \\
\hline 9 & 16 & 5.7 & 10 & 24 & 5.9 & 5.5 & 5.5 & 5.2 & 5.0 & 5.6 & 4.7 & 7.9 \\
\hline 10 & 13 & 5.7 & 9.3 & 20 & 6.3 & 5.6 & 5.3 & 5.1 & 4.6 & 4.3 & 4.5 & 22 \\
\hline 11 & 24 & 8.9 & 8.2 & 16 & 6.6 & 5.5 & 5.2 & 5.7 & 4.3 & 4.3 & 4.4 & 12 \\
\hline 12 & 20 & 8.6 & 7.9 & 14 & 5.9 & 5.2 & 5.5 & 6.0 & 4.0 & 4.3 & 4.6 & 9.2 \\
\hline 13 & 16 & 6.6 & 9.3 & 12 & 7.3 & 6.6 & 5.7 & 7.0 & 4.2 & 4.1 & 4.8 & 8.1 \\
\hline 14 & 13 & 5.8 & 9.0 & 11 & 6.0 & 5.4 & 5.6 & 5.6 & 4.2 & 4.1 & 8.8 & 8.6 \\
\hline 15 & 11 & 5.6 & 8.9 & 17 & 5.5 & 11 & 8.4 & 5.3 & 6.3 & 4.2 & 14 & 8.7 \\
\hline 16 & 10 & 19 & 12 & 14 & 5.5 & 6.0 & 5.4 & 5.0 & 5.3 & 5.1 & 6.7 & 7.2 \\
\hline 17 & 8.7 & 11 & 28 & 11 & 6.0 & 5.5 & 7.8 & 5.0 & 4.8 & 4.3 & 8.0 & 6.7 \\
\hline 18 & 7.9 & 9.4 & 22 & 9.9 & 6.3 & 5.5 & 4.9 & 7.0 & 4.6 & 4.6 & 6.3 & 6.2 \\
\hline 19 & 7.2 & 8.5 & 17 & 9.8 & 10 & 7.5 & 5.2 & 5.2 & 4.4 & 4.2 & 5.6 & 5.8 \\
\hline 20 & 6.9 & 8.1 & 14 & 16 & 5.9 & 5.2 & 5.3 & 5.3 & 4.4 & 4.4 & 5.0 & 87 \\
\hline 21 & 11 & 45 & 12 & 15 & 6.4 & 5.7 & 5.5 & 4.8 & 4.4 & 8.7 & 4.6 & 11 \\
\hline 22 & 8.0 & 29 & 11 & 13 & 5.4 & 5.8 & 5.3 & 4.6 & 4.2 & 4.8 & 4.5 & 8.2 \\
\hline 23 & 6.9 & 18 & 87 & 12 & 5.0 & 5.9 & 5.4 & 4.9 & 9.9 & 4.5 & 4.8 & 7.4 \\
\hline 24 & 29 & 14 & 14 & 10 & 5.5 & 5.8 & 4.9 & 4.9 & 5.3 & 4.1 & 4.8 & 6.2 \\
\hline 25 & 19 & 13 & 26 & 11 & 5.6 & 5.6 & 4.8 & 4.9 & 7.3 & 4.3 & 4.5 & 6.0 \\
\hline 26 & 15 & 14 & 23 & 22 & 5.4 & 5.6 & 5.0 & 4.9 & 6.9 & 4.7 & 6.9 & 5.9 \\
\hline 27 & 12 & 11 & 40 & 23 & 5.3 & 5.3 & 5.1 & 4.9 & 9.7 & 4.3 & 11 & 5.6 \\
\hline 28 & 11 & 10 & 26 & 12 & 5.4 & 5.6 & 5.4 & 4.8 & 5.2 & 4.2 & 7.1 & 13 \\
\hline 29 & 9.2 & & 19 & 11 & 5.1 & 5.7 & 5.3 & 4.7 & 4.9 & 4.4 & 6.0 & 14 \\
\hline 30 & 8.3 & & 15 & 10 & 4.9 & 10 & 5.1 & 4.8 & 4.6 & 7.5 & 5.3 & 9.6 \\
\hline 31 & 7.6 & & 26 & & 7.8 & & 4.9 & 4.9 & & 5.0 & & 8.5 \\
\hline TOTAL & 390.5 & 307.3 & 611.2 & 421.7 & 201.0 & 177.5 & 1727 & 176.6 & 165.9 & 144.4 & 183.4 & 411.4 \\
\hline MEAN & 126 & 11.0 & 19.7 & 14.1 & 6.48 & 5.92 & 5.57 & 5.70 & 5.53 & 4.66 & 6.11 & 13.3 \\
\hline MAX & 29 & 45 & 87 & 24 & 11 & 11 & 8.4 & 16 & 10 & 87 & 14 & 116 \\
\hline $\mathrm{MmN}$ & 6.9 & 5.6 & 7.9 & 9.8 & 4.9 & 4.7 & 4.8 & 4.5 & 4.0 & 4.1 & 4.3 & 4.8 \\
\hline $\begin{array}{l}\text { RUNOFF } \\
\text { (in) }\end{array}$ & 4.43 & 259 & 8.77 & 4.49 & 221 & 201 & 1.92 & 1.92 & 1.92 & 1.64 & 2.08 & 4.53 \\
\hline
\end{tabular}


Table C.14. Daily streamflow (cfs) at monitoring station GS4 (USGS 03536440) for the period January-December 1993

\begin{tabular}{|c|c|c|c|c|c|c|c|c|c|c|c|c|}
\hline DAY & JAN & FEB & MAR & APR & MAY & JUN & JUL & AUG & SEP & OCT & Nov & DEC \\
\hline 1 & .71 & .44 & .73 & 24 & .43 & .24 & 31 & .19 & .35 & .21 & 20 & 30 \\
\hline 2 & .59 & .40 & .73 & 1.5 & .36 & .24 & .28 & .20 & .34 & .20 & .19 & 30 \\
\hline 3 & 51 & .38 & 1.4 & 1.0 & .32 & .20 & .24 & .23 & .50 & .19 & .17 & .34 \\
\hline 4 & .80 & 33 & 5.7 & .80 & .61 & .24 & .22 & .41 & .67 & .17 & .20 & 24 \\
\hline 5 & 25 & .33 & 24 & 1.3 & .34 & .24 & .21 & .22 & .34 & .17 & .65 & 6.2 \\
\hline 6 & 1.4 & .29 & 1.5 & 1.0 & .31 & .18 & .21 & .92 & 33 & .17 & .29 & 1.7 \\
\hline 7 & 1.1 & .28 & 1.1 & .81 & .30 & .25 & .23 & .33 & .33 & .16 & .22 & 1.1 \\
\hline 8 & 3.0 & .26 & .90 & .72 & .24 & .30 & .22 & .28 & .27 & .18 & .20 & .72 \\
\hline 9 & 1.8 & .27 & .73 & 3.2 & 2 & .25 & .24 & .28 & .29 & .21 & .20 & .63 \\
\hline 10 & 1.3 & .28 & .63 & 24 & .23 & .26 & .22 & .30 & 38 & .17 & .19 & .55 \\
\hline 11 & 3.3 & .48 & .51 & 1.5 & .28 & .27 & .21 & .35 & .32 & .19 & .18 & 27 \\
\hline 12 & 26 & .87 & .49 & 1.1 & .24 & .24 & 21 & .38 & 31 & .19 & .19 & 1.2 \\
\hline 13 & 1.8 & .49 & .58 & .80 & .34 & .26 & .24 & .41 & .28 & .16 & .17 & .79 \\
\hline 14 & 1.2 & .40 & .57 & .65 & .26 & .24 & .24 & .31 & .20 & .16 & .45 & .60 \\
\hline 15 & .94 & 35 & .55 & 1.8 & .23 & .43 & .35 & .29 & 32 & .17 & 1.4 & .62 \\
\hline 16 & .75 & 23 & 1.0 & 1.5 & .20 & .24 & .25 & 28 & 25 & .20 & .44 & .87 \\
\hline 17 & .62 & 1.1 & 4.5 & .88 & .25 & 36 & .35 & .31 & 24 & .17 & .46 & .64 \\
\hline 18 & .54 & .79 & 3.3 & .69 & .30 & .24 & .24 & .51 & .22 & .17 & .42 & .53 \\
\hline 19 & 59 & .64 & 21 & .57 & 57 & 30 & .25 & .31 & .21 & .17 & 34 & .45 \\
\hline 20 & 50 & .55 & 1.6 & 1.5 & 31 & 2 & .26 & .32 & .21 & .16 & 28 & .57 \\
\hline 21 & .94 & 8.2 & 1.2 & 15 & .38 & 22 & .24 & 30 & 23 & .39 & .26 & 1.1 \\
\hline 22 & .69 & 4.1 & 1.0 & .93 & .27 & .23 & .23 & .29 & 22 & .21 & .24 & .59 \\
\hline 23 & .53 & 20 & 19 & .75 & .24 & .21 & .25 & .27 & 53 & .17 & .24 & .45 \\
\hline 24 & 5.8 & 1.3 & 6.7 & .61 & .23 & 23 & .23 & 32 & 25 & .16 & 25 & 37 \\
\hline 25 & 27 & 1.0 & 29 & .64 & .27 & .24 & .21 & $30(e)$ & 32 & .16 & 23 & .33 \\
\hline 26 & 1.6 & 1.1 & 22 & 27 & .26 & .23 & .21 & .29 & .33 & .17 & .39 & .28 \\
\hline 27 & 1.1 & 1.0 & 6.3 & 1.1 & 22 & 20 & .21 & 35 & .53 & .94 & 1.0 & .26 \\
\hline 28 & .82 & .79 & 3.0 & .81 & .23 & .23 & .27 & .33 & .25 & .16 & .63 & 1.0 \\
\hline 29 & .66 & & 1.8 & .64 & .21 & .26 & .25 & .33 & .20 & .19 & .41 & 1.6 \\
\hline 30 & .52 & & 1.3 & .55 & .19 & .55 & .24 & 33 & .20 & 37 & 35 & .81 \\
\hline 31 & .46 & & 24 & & .34 & & .20 & .34 & & .22 & & .60 \\
\hline TOTAL & 4237 & 30.72 & 78.82 & 36.35 & 9.18 & 7.80 & 7.52 & 10.31 & 9.42 & 6.71 & 10.84 & 5220 \\
\hline MEAN & 1.37 & 1.10 & 254 & 1.21 & .30 & 26 & .24 & .33 & 31 & .22 & 36 & 1.68 \\
\hline MAX & 5.8 & 8.2 & 19 & 3.2 & .61 & .55 & .35 & .92 & .67 & .94 & 1.4 & 24 \\
\hline MIN & .46 & .26 & .49 & .55 & .19 & .18 & 20 & .19 & 20 & .16 & .17 & .26 \\
\hline $\begin{array}{l}\text { RUNOFF } \\
\text { (in) }\end{array}$ & 236 & 0.49 & 5.98 & 202 & 0.52 & .43 & .36 & .57 & .48 & .38 & .60 & 289 \\
\hline
\end{tabular}


Table C.15. Daily streamflow (cfs) at monitoring station GS5 (USGS 03536380) for the period January-December 1993

\begin{tabular}{|c|c|c|c|c|c|c|c|c|c|c|c|c|}
\hline DAY & JAN & FEB & MAR & APR & MAY & JUN & JUL & AUG & SEP & OCT & Nov & DEC \\
\hline 1 & 5.3 & 4.2 & 5.2 & 12 & 4.6 & 26 & 29 & 1.9 & 21 & 1.9 & 22 & 22 \\
\hline 2 & 4.5 & 3.8 & 5.7 & 9.5 & 4.2 & 24 & 24 & 20 & 23 & 22 & 20 & 22 \\
\hline 3 & 4.1 & 3.5 & 8.3 & 7.7 & 3.9 & 24 & 21 & 20 & 3.8 & 19 & 20 & 22 \\
\hline 4 & 6.4 & 3.3 & 20 & 6.9 & 6.0 & 24 & 2.0 & 3.9 & 5.3 & 1.8 & 23 & 76 \\
\hline 5 & 10 & 3.2 & 12 & 9.5 & 3.9 & 22 & 20 & 21 & 1.8 & 1.8 & 6.4 & 25 \\
\hline 6 & 6.5 & 3.1 & 9.0 & 7.0 & 3.6 & 21 & 20 & 9.3 & 1.6 & 1.7 & 26 & 9.0 \\
\hline 7 & 6.8 & 3.0 & 7.3 & 6.3 & 3.3 & 23 & 21 & 24 & 1.8 & 1.8 & 22 & 5.9 \\
\hline 8 & 13 & 3.0 & 6.3 & 6.0 & 3.1 & 23 & 21 & 22 & 21 & 1.7 & 21 & 4.6 \\
\hline 9 & 9.3 & 29 & 5.4 & 14 & 3.0 & 23 & 20 & 21 & 20 & 26 & 21 & 3.9 \\
\hline 10 & 7.7 & 29 & 4.9 & 10 & 3.1 & 23 & 21 & 21 & 20 & 1.8 & 20 & 13 \\
\hline 11 & 15 & 4.9 & 4.4 & 8.9 & 3.1 & 21 & 20 & 25 & 1.9 & 20 & 20 & 6.4 \\
\hline 12 & 12 & 4.4 & 4.4 & 2.4 & 3.1 & 1.8 & 21 & 25 & 1.9 & 1.9 & 20 & 5.0 \\
\hline 13 & 9.5 & 3.5 & 5.2 & 6.4 & 4.1 & 27 & 22 & 3.2 & 1.8 & 1.8 & 1.9 & 4.1 \\
\hline 14 & 7.6 & 3.2 & 4.9 & 5.8 & 3.2 & 1.9 & 21 & 22 & 1.8 & 1.8 & 4.7 & 4.5 \\
\hline 15 & 6.4 & 3.1 & 3.9 & 10 & 3.0 & 5.7 & 4.2 & 21 & 3.0 & 1.8 & 6.9 & 4.5 \\
\hline 16 & 5.8 & 11 & 6.9 & 7.5 & 3.0 & 21 & 22 & 21 & 23 & 22 & 3.1 & 3.7 \\
\hline 17 & 5.0 & 5.9 & 16 & 6.2 & 29 & 20 & 3.9 & 20 & 20 & 1.9 & 3.9 & 3.4 \\
\hline 18 & 4.4 & 5.5 & 13 & 5.6 & 3.4 & 20 & 22 & 3.2 & 20 & 1.9 & 29 & 3.3 \\
\hline 19 & 4.0 & 4.9 & 9.8 & 5.3 & 5.6 & 3.5 & 22 & 21 & 1.9 & 1.9 & 26 & 3.0 \\
\hline 20 & 3.8 & 4.6 & 8.0 & 9.5 & 3.1 & 22 & 21 & 21 & 1.9 & 20 & 22 & 4.9 \\
\hline 21 & 6.5 & 30 & 6.8 & 8.2 & 3.5 & 25 & 21 & 1.9 & 28 & 4.7 & 21 & 5.5 \\
\hline 22 & 4.3 & 17 & 6.2 & 7.1 & 29 & 24 & 21 & 1.8 & 1.8 & 21 & 20 & 4.1 \\
\hline 23 & 3.9 & 11 & 57 & 6.4 & 28 & 24 & 21 & 1.8 & 5.7 & 1.9 & 20 & 3.7 \\
\hline 24 & 19 & 8.1 & 27 & 5.5 & 29 & 23 & 20 & 1.9 & 24 & 1.8 & 20 & 3.4 \\
\hline 25 & 12 & 7.2 & 15 & 6.2 & 29 & 22 & 20 & 1.9 & 3.5 & 1.9 & 1.9 & 3.3 \\
\hline 26 & 8.7 & 7.9 & 14 & 12 & 29 & 21 & 21 & 19 & 3.4 & 20 & 3.6 & 3.0 \\
\hline 27 & 7.3 & 6.4 & 24 & 7.0 & 26 & 20 & 21 & 19 & 5.2 & 1.9 & 5.9 & 29 \\
\hline 28 & 6.3 & 5.5 & 15 & 6.3 & 24 & 22 & 20 & 1.9 & 24 & 20 & 3.4 & 7.6 \\
\hline 29 & 5.3 & & 11 & 5.6 & 25 & 22 & 20 & 20 & 21 & 22 & 28 & 7.4 \\
\hline 30 & 4.7 & & 8.9 & 5.0 & 23 & 5.3 & 20 & 20 & 20 & 4.1 & 24 & 5.3 \\
\hline 31 & 4.3 & & 16 & & 4.2 & & 1.9 & 20 & & 25 & & 4.6 \\
\hline TOTAL & 229.4 & 177.0 & 3625 & 230.8 & 105.1 & 74.9 & 69.3 & 75.0 & 75.6 & 65.5 & 86.2 & 237.6 \\
\hline MEAN & 7.40 & 6.32 & 11.7 & 7.69 & 3.39 & 250 & 224 & 242 & 252 & 211 & 287 & 7.66 \\
\hline MAX & 19 & 30 & 57 & 14 & 6.0 & 5.7 & 4.2 & 9.3 & 5.7 & 4.7 & 6.9 & 76 \\
\hline MnN & 3.8 & 29 & 4.4 & 5.0 & 23 & 1.8 & 1.9 & 1.8 & 1.6 & 1.7 & 1.9 & 22 \\
\hline $\begin{array}{l}\text { RUNOFF } \\
\text { (in) }\end{array}$ & 4.06 & 1.62 & 8.33 & 4.09 & 1.86 & 1.33 & 1.34 & 1.34 & 1.34 & 1.16 & 1.53 & 4.21 \\
\hline
\end{tabular}


Table C.16. Daily streamflow (cfs) at monitoring station GS6 (USGS 03536320) for the period January-December 1993

\begin{tabular}{|c|c|c|c|c|c|c|c|c|c|c|c|c|}
\hline DAY & JAN & FEB & MAR & APR & MAY & JUN & JUL & AUG & SEP & OCT & Nov & DEC \\
\hline 1 & 1.1 & .48 & 1.1 & 3.5 & 1.0 & .13 & .15 & .02 & .02 & .05 & .09 & .09 \\
\hline 2 & .81 & .30 & 1.2 & 26 & .81 & .10 & .07 & .03 & .03 & .11 & .07 & .07 \\
\hline 3 & .54 & .17 & 22 & 20 & .62 & .08 & .07 & .02 & .46 & .05 & .05 & .10 \\
\hline 4 & 1.2 & .12 & 7.3 & 1.8 & 1.1 & .08 & .05 & .40 & .97 & .04 & .18 & 40 \\
\hline 5 & 24 & .12 & 3.9 & 25 & .50 & .08 & .05 & .05 & .06 & .03 & 1.1 & 11 \\
\hline 6 & 1.5 & .11 & 25 & 1.7 & .37 & .06 & .06 & 1.8 & .04 & .03 & .15 & 23 \\
\hline 7 & 1.6 & .11 & 20 & 1.5 & 30 & .07 & .06 & .13 & .04 & .03 & .09 & 1.0 \\
\hline 8 & 3.9 & .10 & 1.6 & 1.4 & .23 & .06 & .06 & .06 & .03 & .03 & .07 & .53 \\
\hline 9 & 25 & .19 & 1.3 & 4.4 & .17 & .05 & .06 & .05 & .03 & .20 & .06 & .20 \\
\hline 10 & 20 & .10 & 1.2 & 3.1 & .12 & .04 & .06 & .04 & .03 & .06 & .05 & 3.5 \\
\hline 11 & 5.0 & .63 & .93 & 25 & .12 & .03 & .06 & .14 & .02 & .12 & .05 & 1.3 \\
\hline 12 & 3.9 & .49 & .82 & 20 & .13 & .04 & .06 & .14 & .02 & .07 & .05 & .87 \\
\hline 13 & 28 & 20 & 1.1 & 1.7 & 37 & .30 & .07 & .35 & .02 & .05 & .04 & .50 \\
\hline 14 & 20 & .15 & 1.0 & 1.4 & .24 & .06 & .05 & .11 & .02 & .04 & 1.0 & 51 \\
\hline 15 & 1.6 & .13 & .95 & 26 & .15 & 1.2 & so & .05 & .26 & .05 & .99 & .52 \\
\hline 16 & 1.3 & 25 & 1.5 & 1.8 & .10 & .09 & .07 & .04 & .10 & .17 & .19 & .22 \\
\hline 17 & .98 & 1.2 & 5.0 & 1.5 & .09 & .08 & .42 & .03 & .04 & .11 & .42 & .16 \\
\hline 18 & .68 & 1.1 & 4.4 & 1.4 & .19 & .06 & .09 & .53 & .03 & .10 & .17 & .13 \\
\hline 19 & .42 & .99 & 3.0 & 1.2 & .87 & .33 & .07 & .07 & .02 & .08 & .11 & .11 \\
\hline 20 & .24 & .79 & 23 & 27 & .20 & .08 & .04 & .09 & .02 & .07 & .08 & .65 \\
\hline 21 & 1.0 & 12 & 1.8 & 21 & .36 & .10 & .04 & .05 & .02 & .82 & .07 & .77 \\
\hline 22 & .50 & 6.9 & 1.5 & 1.8 & .16 & .07 & .03 & .03 & .02 & .11 & .06 & .41 \\
\hline 23 & .39 & 3.5 & 29 & 1.6 & .11 & .06 & .02 & .03 & .88 & .07 & .06 & .28 \\
\hline 24 & 6.6 & 22 & 13 & 1.4 & .09 & .06 & .02 & .03 & .10 & .06 & .05 & .15 \\
\hline 25 & 3.5 & 1.8 & 5.6 & 1.6 & .14 & .06 & .02 & .02 & .43 & .05 & .05 & .14 \\
\hline 26 & 25 & 21 & 4.7 & 3.7 & .11 & .05 & .02 & .02 & .38 & .05 & .55 & .11 \\
\hline 27 & 1.8 & 1.5 & 11 & 1.8 & .09 & .04 & .08 & .02 & .74 & .04 & .99 & .10 \\
\hline 28 & 1.4 & 1.2 & 5.8 & 1.6 & .08 & .04 & .02 & .03 & .10 & .04 & $2 n$ & 1.5 \\
\hline 29 & 1.0 & & 3.6 & 1.4 & .12 & .05 & .02 & .03 & .06 & .10 & .16 & 1.5 \\
\hline 30 & $\pi 7$ & & 25 & 1.2 & .08 & .61 & .01 & .02 & .04 & .62 & .11 & .99 \\
\hline 31 & .60 & & 5.2 & & .56 & & .02 & .02 & & .17 & & .76 \\
\hline TOTAL & 56.53 & 41.09 & 129.00 & 61.5 & 9.58 & 4.16 & 242 & 4.45 & 5.03 & 3.62 & 7.38 & 70.47 \\
\hline MEAN & 1.82 & 1.47 & 4.16 & 205 & .31 & .14 & .078 & .14 & .17 & .12 & 25 & 227 \\
\hline MAX & 6.6 & 12 & 29 & 4.4 & 1.1 & 1.2 & .50 & 1.8 & .97 & .82 & 1.1 & 40 \\
\hline $\mathrm{MmN}$ & 24 & .10 & .82 & 1.2 & .08 & .03 & .01 & .02 & .02 & .03 & .04 & .07 \\
\hline $\begin{array}{l}\text { RUNOFF } \\
\text { (in) }\end{array}$ & 1.61 & 1.17 & 3.66 & 1.75 & .27 & .12 & .07 & .13 & .14 & .10 & .21 & 200 \\
\hline
\end{tabular}


Table C.17 Daily streamflow (cfs) at monitoring station GS16 (USGS 03537050) for the period January-September 1993

\begin{tabular}{|c|c|c|c|c|c|c|c|c|c|}
\hline DAY & JAN & FEB & MAR & APR & MAY & JUN & JUL & AUG & SEP' \\
\hline 1 & $.20(e)$ & .13 & .27 & 1.4 & .11 & .06 & .01 & .00 & .00 \\
\hline 2 & $.14(\mathrm{e})$ & .11 & 31 & .60 & .09 & .02 & .00 & .00 & .00 \\
\hline 3 & $.12(e)$ & .10 & .59 & .37 & .08 & .01 & .00 & .00 & .00 \\
\hline 4 & $.20(e)$ & .09 & 29 & .29 & .28 & .01 & .00 & .00 & .00 \\
\hline 5 & $1.0(e)$ & .09 & .71 & .67 & .10 & .01 & .00 & .00 & .00 \\
\hline 6 & $.60(e)$ & .08 & .40 & .44 & .06 & .01 & .00 & .08 & .00 \\
\hline 7 & .35 & .08 & 30 & 32 & .04 & .01 & .00 & .01 & .00 \\
\hline 8 & 1.7 & .08 & .25 & .26 & .03 & .01 & .00 & .00 & .00 \\
\hline 9 & .70 & .08 & .20 & 1.5 & .03 & .01 & .00 & .00 & .00 \\
\hline 10 & .41 & .07 & .18 & .94 & .02 & .01 & .00 & .00 & .00 \\
\hline 11 & 1.8 & .23 & .15 & .44 & .01 & .01 & .00 & .00 & .00 \\
\hline 12 & 1.1 & .40 & .16 & .29 & .01 & .01 & .00 & .01 & .00 \\
\hline 13 & .57 & .21 & $.2 n$ & .22 & .02 & .01 & .00 & .01 & .00 \\
\hline 14 & .35 & .16 & .23 & .21 & .03 & .01 & .00 & .00 & .00 \\
\hline 15 & .26 & .14 & $.2 n$ & .45 & .01 & .28 & .00 & .00 & .00 \\
\hline 16 & .22 & 2.1 & 59 & 38 & .01 & .02 & .00 & .00 & .00 \\
\hline 17 & .18 & .48 & 27 & .21 & .01 & .01 & .03 & .00 & .00 \\
\hline 18 & .15 & .29 & 1.1 & .17 & .01 & .01 & .01 & $.0 !$ & .00 \\
\hline 19 & .14 & 22 & 53 & .16 & .38 & .01 & .01 & .00 & .00 \\
\hline 20 & .14 & .19 & .40 & .77 & .06 & .01 & .00 & .00 & .00 \\
\hline 21 & .46 & 3.8 & 32 & 1.0 & .06 & .01 & .00 & .00 & .00 \\
\hline 22 & .30 & 1.2 & .28 & .42 & .05 & .01 & .00 & .00 & .00 \\
\hline 23 & .23 & .47 & $7.4(\mathrm{e})$ & .27 & .02 & .01 & .00 & .00 & .01 \\
\hline 24 & 3.2 & .29 & $1.0(e)$ & 20 & .01 & .00 & .00 & .00 & .00 \\
\hline 25 & .93 & .26 & so(e) & .19 & .02 & .00 & .00 & .00 & .01 \\
\hline 25 & .49 & .54 & so(e) & 1.7 & .03 & .00 & .00 & .00 & .01 \\
\hline 27 & 29 & .48 & $3.0(e)$ & .42 & .01 & .00 & .00 & .00 & .02 \\
\hline 28 & 22 & 34 & $.70(e)$ & .25 & .01 & .00 & .00 & .00 & .00 \\
\hline 29 & .18 & & $.40(e)$ & .18 & .01 & .00 & .00 & .00 & .00 \\
\hline 30 & .15 & & $.35(c)$ & .14 & .01 & .01 & .00 & .00 & .00 \\
\hline 31 & .15 & & 1.2 & & .15 & & .00 & .00 & \\
\hline TOTAL & 16.93 & 11.71 & 28.16 & 14.86 & 1.77 & 0.58 & .06 & .12 & .05 \\
\hline MEAN & .55 & .42 & .91 & .50 & .057 & .019 & .002 & .004 & .002 \\
\hline MAX & 3.2 & 3.8 & 2.4 & 1.7 & 38 & .28 & .03 & .08 & .02 \\
\hline MIN & .12 & .07 & .15 & .14 & .01 & .00 & .00 & .00 & .00 \\
\hline $\begin{array}{l}\text { RUNOFP } \\
\text { (ii) }\end{array}$ & 262 & 1.82 & 4.36 & 230 & .27 & .09 & .01 & .02 & .01 \\
\hline
\end{tabular}

'Monitoring was diccontinued on Seplember 30, 1993

(e) - Estimated dats. 
Table C.18 Daily streamflow (cfs) at monitoring station GS17 (USGS03537200) for the period Janaury-September 1993

\begin{tabular}{|c|c|c|c|c|c|c|c|c|c|}
\hline DAY & JAN & FEB & MAR & APR & MAY & JUN & JUL & AUG & SEP: \\
\hline 1 & $.08(e)$ & .06 & .11 & .48 & .08 & .04 & .02 & .00 & .00 \\
\hline 2 & $.06(e)$ & .05 & .11 & .23 & .07 & .02 & .01 & .00 & .00 \\
\hline 3 & $.05(\mathrm{c})$ & .05 & .17 & .16 & .07 & .02 & .01 & .00 & .00 \\
\hline 4 & $.10(e)$ & .05 & .86 & .13 & .12 & .02 & .01 & .01 & .02 \\
\hline 5 & $.40(e)$ & .04 & .25 & .22 & .06 & .01 & .01 & .01 & .00 \\
\hline 6 & $.12(e)$ & .04 & .15 & .18 & .05 & .01 & .01 & .07 & .00 \\
\hline 7 & .13 & .04 & .11 & .15 & .05 & .01 & .01 & .01 & .00 \\
\hline 8 & .44 & .04 & .10 & .12 & .04 & .01 & .00 & .01 & .00 \\
\hline 9 & .23 & .04 & .09 & .44 & .04 & .01 & .00 & .00 & .00 \\
\hline 10 & .14 & .04 & .08 & .36 & .04 & .01 & .00 & .00 & .00 \\
\hline 11 & .47 & .08 & .07 & .19 & .04 & .01 & .00 & .01 & .00 \\
\hline 12 & .37 & .10 & .07 & .13 & .03 & .01 & .00 & .01 & .00 \\
\hline 13 & .18 & .08 & .09 & .11 & .04 & .01 & .01 & .02 & .00 \\
\hline 14 & .12 & .07 & .08 & .10 & .04 & .01 & .01 & .01 & .00 \\
\hline 15 & .10 & .06 & .09 & .17 & .03 & .12 & .01 & .01 & .01 \\
\hline 16 & .08 & .30 & .17 & .18 & .03 & .02 & .01 & .00 & .01 \\
\hline 17 & .07 & .18 & .84 & .13 & .03 & .01 & .05 & .00 & .01 \\
\hline 18 & .06 & .11 & .39 & .11 & .04 & .01 & .01 & .01 & .00 \\
\hline 19 & .06 & .09 & .19 & .10 & .14 & .02 & .01 & .00 &.$\infty 0$ \\
\hline 20 & .05 & .08 & .14 & .22 & .04 & .01 & .01 & .00 & .00 \\
\hline 21 & .12 & 1.0 & .12 & 34 & .05 & .01 & .01 & .00 & .00 \\
\hline 22 & .09 & .42 & .10 & .18 & .04 & .01 & .00 & .00 & .00 \\
\hline 23 & $.07(e)$ & .17 & 22 & .13 & .03 & .01 & .00 & .00 & .03 \\
\hline 24 & $.45(\mathrm{e})$ & .11 & .57 & .10 & .03 & .01 & .00 & .00 & .01 \\
\hline 25 & $.30(c)$ & .10 & 22 & .11 & .03 & .01 & .00 & .00 & .01 \\
\hline 26 & $.16(e)$ & .15 & 22 & .49 & .04 & .01 & .00 & .00 & .01 \\
\hline 27 & .11 & .15 & .93 & .19 & .03 & .01 & .00 & .00 & .03 \\
\hline 28 & .09 & .13 & .34 & .13 & .02 & .01 & .00 & .00 & .01 \\
\hline 29 & .08 & & .19 & .11 & .02 & .01 & .00 & .00 & .01 \\
\hline 30 & .07 & & .14 & .09 & .02 & .02 & .00 & .00 & .00 \\
\hline 31 & .06 & & .37 & & .07 & & .00 & .00 & \\
\hline TOTAL & 4.91 & 3.83 & 9.56 & 5.78 & 1.46 & .50 & .21 & .18 & .16 \\
\hline MEAN & .16 & .14 & 31 & .19 & .047 & .017 & .007 & .006 & .005 \\
\hline MAX & .47 & 1.0 & 22 & .49 & .14 & .12 & .05 & .07 & .03 \\
\hline MIN & .05 & .04 & .07 & .09 & .02 & .01 & .00 & .00 & .00 \\
\hline RUNOFF (in) & 261 & 204 & 5.08 & 3.07 & .78 & .27 & .11 & .10 & .09 \\
\hline
\end{tabular}


Table C.19 Daily streamflow (cfs) at monitoring station GS18 (USGS03537300) for the period January-September 1993

\begin{tabular}{|c|c|c|c|c|c|c|c|c|c|}
\hline & JAN & FEB & MAR & APR & MAY & JUN & JUL & AUG & SEP' \\
\hline 1 & .16 & .08 & .25 & 1.2 & .09 & .03 & $.00(e)$ & .00 & .00 \\
\hline 2 & .12 & .06 & .24 & .68 & .07 & .01 & $.00(\mathrm{e})$ & .00 & .00 \\
\hline 3 & .10 & .05 & .35 & .44 & .07 & .01 & $.00(\mathrm{e})$ & .00 & .00 \\
\hline 4 & .19 & .05 & 1.7 & .42 & .20 & .00 & $.00(\mathrm{e})$ & .00 & .00 \\
\hline 5 & .82 & .05 & .62 & .61 & .10 & .00 & $.00(e)$ & .00 & .00 \\
\hline 6 & .22 & .05 & .40 & 58 & .05 & .00 & $.00(\varepsilon)$ & .08 & .00 \\
\hline 7 & .33 & .04 & 29 & .43 & .03 & .00 & $.00(e)$ & .00 & .00 \\
\hline 8 & 1.8 & .04 & .22 & .28 & .02 & .00 & $.00(e)$ & .00 & .00 \\
\hline 9 & .58 & .04 & .15 & .86 & .02 & .00 & $.00(\mathrm{e})$ & .00 & .00 \\
\hline 10 & .17 & .04 & .13 & .77 & .02 & .00 & $.00(c)$ & .00 & .00 \\
\hline 11 & 1.5 & .12 & .10 & .49 & .01 & .00 & $.00(\mathrm{e})$ & .00 & .00 \\
\hline 12 & 1.2 & 24 & .10 & 34 & .01 & .00 & $.00(e)$ & .00 & .00 \\
\hline 13 & .41 & .13 & .17 & .23 & .03 & .00 & $.00(\mathrm{c})$ & .00 & .00 \\
\hline 14 & .34 & .10 & .13 & .17 & .06 & .00 & .00 & $.00(e)$ & .00 \\
\hline 15 & .17 & .08 & .18 & .35 & .03 & .13 & .00 & $.00(\mathrm{e})$ & .00 \\
\hline 16 & .17 & .63 & .40 & .49 & .01 & .01 & .00 & $.00(\mathrm{e})$ & .00 \\
\hline 17 & .13 & .47 & 1.7 & .33 & .01 & .00 & .02 & $.00(e)$ & .00 \\
\hline 18 & .10 & .29 & 1.4 & .23 & .02 & .00 & .00 & $.00(e)$ & .00 \\
\hline 19 & .08 & .18 & .49 & .17 & .28 & .01 & .00 & $.00(c)$ & .00 \\
\hline 20 & .08 & .15 & 29 & .41 & .06 & .00 & .00 & $.00(e)$ & .00 \\
\hline 21 & .28 & 23 & .28 & .72 & .05 & .00 & .00 & $.00(e)$ & .00 \\
\hline 22 & .23 & .94 & .13 & .46 & .04 & .00 & .00 & $.00(e)$ & .00 \\
\hline 23 & .18 & .47 & 5.7 & .30 & .02 & .00 & .00 & $.00(e)$ & .01 \\
\hline 24 & 1.8 & 30 & 1.8 & .20 & .01 & .00 & .00 & $.00(e)$ & .00 \\
\hline 25 & .72 & 22 & .86 & .18 & .01 & $.00(c)$ & .00 & $.00(e)$ & .00 \\
\hline 26 & .43 & .31 & .85 & 1.0 & .02 & $.00(0)$ & .00 & $.00(\theta)$ & .00 \\
\hline 27 & .28 & .36 & 28 & .48 & .01 & $.00(e)$ & .00 & $.00(e)$ & .04 \\
\hline 28 & .18 & .34 & 1.4 & .29 & .01 & $.00(e)$ & .00 & .00 & .00 \\
\hline 29 & .13 & & $.80(e)$ & .18 & .00 & $.00(e)$ & .00 & .00 & .00 \\
\hline 30 & .10 & & $.30(c)$ & .12 & .01 & $.00(e)$ & .00 & .00 & .00 \\
\hline 31 & .09 & & .74 & & .07 & & .00 & .00 & \\
\hline TOTAL & 13.09 & 8.13 & 24.97 & 23.24 & 1.44 & 0.20 & 0.02 & 0.08 & 0.05 \\
\hline MEAN & .42 & .29 & .81 & .44 & .046 & .007 & .001 & .003 & .002 \\
\hline MAX & 1.8 & 23 & 5.7 & 1.2 & .28 & .13 & .02 & .08 & .04 \\
\hline MIN & .08 & .04 & .10 & .12 & .00 &.$\infty$ & .00 & .00 & .00 \\
\hline RUNOFP (in) & 3.25 & 202 & 6.19 & 3.28 & 36 & .05 & .00 & .02 & .01 \\
\hline
\end{tabular}


Appendix D

REVISIONS AND ADDITIONS TO RATING TABLES FOR MONITORING STATIONS IN WHITE OAK CREEK WATERSHED 
Table D.15 Rating table for the critical-flow flume at the First Creek station (GS1, USGS 03536450) located above the confluence with Northwest tributary

\begin{tabular}{|c|c|c|c|c|c|c|c|c|c|c|}
\hline \multirow{2}{*}{$\begin{array}{c}\text { GAGE } \\
\text { HEIGHT } \\
\text { (ft) } \\
\end{array}$} & \multicolumn{10}{|c|}{$\begin{array}{l}\text { DISCHARGE } \\
\text { (cfs) }\end{array}$} \\
\hline & 0.00 & 0.01 & 0.02 & 0.03 & 0.04 & 0.05 & 0.06 & 0.07 & 0.08 & 0.09 \\
\hline 0.3 & & & 0.000 & 0.007 & 0.014 & 0.022 & 0.031 & 0.038 & 0.045 & 0.054 \\
\hline 0.4 & 0.065 & 0.073 & 0.082 & 0.092 & 0.103 & 0.115 & 0.125 & 0.136 & 0.147 & 0.159 \\
\hline 0.5 & 0.172 & 0.184 & 0.196 & 0.209 & 0.223 & 0.237 & 0.252 & 0.268 & 0.285 & 0.302 \\
\hline 0.6 & 0.320 & 0.340 & 0.360 & 0.382 & 0.404 & 0.427 & 0.453 & 0.481 & 0.509 & 0.539 \\
\hline 0.7 & 0.570 & 0.599 & 0.629 & 0.660 & 0.593 & 0.726 & 0.760 & 0.796 & 0.833 & 0.871 \\
\hline 0.8 & 0.910 & 0.946 & 0.984 & 1.02 & 1.06 & 1.10 & 1.14 & 1.19 & 1.23 & 1.27 \\
\hline 0.9 & 1.32 & 1.37 & 1.42 & 1.48 & 1.53 & 1.59 & 1.65 & 1.71 & 1.77 & 1.84 \\
\hline 1.0 & 1.90 & 1.96 & 2.01 & 2.07 & 2.13 & 2.19 & 2.25 & 2.32 & 2.38 & 2.45 \\
\hline 1.1 & 2.51 & 2.58 & 2.65 & 2.72 & 2.79 & 2.86 & 2.94 & 3.01 & 3.09 & 3.16 \\
\hline 1.2 & 3.24 & 3.32 & 3.40 & 3.49 & 3.57 & 3.65 & 3.74 & 3.83 & 3.92 & 4.01 \\
\hline 1.3 & 4.10 & 4.19 & 4.29 & 4.38 & 4.48 & 4.58 & 4.68 & 4.78 & 4.89 & 4.99 \\
\hline 1.4 & 5.10 & 5.21 & 5.31 & 5.42 & 5.53 & 5.64 & 5.75 & 5.87 & 5.98 & 6.10 \\
\hline 1.5 & 6.22 & 6.34 & 6.46 & 6.58 & 6.70 & 6.83 & 6.96 & 7.08 & 7.21 & 7.35 \\
\hline 1.6 & 7.48 & 7.61 & 7.75 & 7.89 & 8.03 & 8.17 & 8.31 & 8.46 & 8.60 & 8.75 \\
\hline 1.7 & 8.90 & 9.05 & 9.21 & 9.36 & 9.52 & 9.68 & 9.84 & 10.00 & 10.17 & 10.33 \\
\hline 1.8 & 10.50 & 10.66 & 10.81 & 10.97 & 11.13 & 11.29 & 11.45 & 11.62 & 11.78 & 11.95 \\
\hline 1.9 & 12.12 & 12.29 & 12.46 & 12.63 & 12.81 & 12.98 & 13.16 & 13.34 & 13.52 & 13.70 \\
\hline
\end{tabular}


Table D.15 (continued)

\begin{tabular}{|c|c|c|c|c|c|c|c|c|c|c|}
\hline \multirow{2}{*}{$\begin{array}{c}\text { GAGE } \\
\text { HEIGHT } \\
\text { (ft) } \\
\end{array}$} & \multicolumn{10}{|c|}{$\begin{array}{c}\text { DISCHARGE } \\
\text { (cfs) }\end{array}$} \\
\hline & 0.00 & 0.01 & 0.02 & 0.03 & 0.04 & 0.05 & 0.06 & 0.07 & 0.08 & 0.09 \\
\hline 2.0 & 13.88 & 14.07 & 14.25 & 14.44 & 14.63 & 14.82 & 15.01 & 15.21 & $\mathbf{1 5 . 4 0}$ & 15.60 \\
\hline 2.1 & 15.80 & 16.09 & 16.38 & 16.67 & 16.97 & 17.27 & 17.57 & 17.88 & 18.19 & 18.51 \\
\hline 2.2 & 18.83 & 19.16 & 19.49 & 19.82 & 20.16 & 20.50 & 20.87 & 21.25 & 21.64 & 22.03 \\
\hline 2.3 & 22.43 & 22.83 & 23.23 & 23.64 & 24.06 & 24.49 & 24.91 & 25.35 & 25.79 & 26.23 \\
\hline 2.4 & 26.68 & 27.14 & 27.60 & 28.07 & 28.55 & 29.03 & 29.52 & 30.01 & 30.51 & 31.01 \\
\hline 2.5 & 31.53 & 32.05 & 32.57 & 33.10 & 33.64 & 34.18 & 34.73 & 35.29 & 35.86 & 36.43 \\
\hline 2.6 & 37.01 & 37.59 & 38.18 & 38.78 & 39.39 & 40.00 & 40.83 & 41.67 & 42.53 & 43.40 \\
\hline 2.7 & 44.29 & 45.19 & 46.11 & 47.04 & 47.99 & 48.95 & 49.93 & 50.92 & 51.93 & 52.96 \\
\hline 2.8 & 54.00 & 54.96 & 55.94 & 56.93 & 57.03 & 58.95 & 59.98 & 61.03 & 62.09 & 63.16 \\
\hline 2.9 & 64.25 & 65.36 & 66.48 & 67.61 & 68.76 & 69.93 & 71.11 & 72.31 & 73.52 & $\mathbf{7 4 . 7 5}$ \\
\hline 3.0 & 76.00 & 77.24 & 78.49 & 79.77 & 81.05 & 82.36 & 83.68 & 85.02 & 86.37 & 87.74 \\
\hline 3.1 & 89.13 & 90.54 & 91.96 & 93.40 & 94.86 & 96.34 & 97.83 & 99.35 & 100.9 & 102.4 \\
\hline 3.2 & 104.0 & 105.6 & 107.1 & 108.7 & 110.4 & 112.0 & 113.7 & 115.3 & 117.0 & 118.8 \\
\hline 3.3 & 120.5 & 122.3 & 124.0 & 125.8 & 127.6 & 129.5 & 131.3 & 133.2 & 135.1 & 137.1 \\
\hline 3.4 & 139.0 & 140.7 & 142.3 & 144.0 & 145.7 & 147.4 & 149.1 & 150.9 & 152.6 & 154.4 \\
\hline 3.5 & 156.2 & 158.0 & 159.8 & 161.6 & 163.5 & 165.3 & 157.2 & 169.1 & 171.0 & 173.0 \\
\hline 3.6 & 174.9 & 176.9 & 178.8 & 180.8 & 182.8 & 184.9 & 186.9 & 189.0 & 191.1 & 193.2 \\
\hline
\end{tabular}


Table D.15 (continued)

\begin{tabular}{|c|c|c|c|c|c|c|c|c|c|c|}
\hline $\begin{array}{c}\text { GAGE } \\
\text { HEIGHT } \\
\text { (ft) }\end{array}$ & \multicolumn{10}{|c|}{$\begin{array}{c}\text { DISCHARGE } \\
\text { (cfs) }\end{array}$} \\
\hline \hline & 0.00 & 0.01 & 0.02 & 0.03 & 0.04 & 0.05 & 0.06 & 0.07 & 0.08 & 0.09 \\
\hline \hline 3.7 & 195.3 & 197.4 & 199.5 & 201.7 & 203.9 & 206.1 & 208.3 & 210.5 & 212.8 & 215.1 \\
\hline 3.8 & 217.4 & 219.7 & 222.0 & 224.3 & 226.7 & 229.1 & 231.5 & 233.9 & 236.3 & 238.8 \\
\hline 3.9 & 241.3 & 243.8 & 246.3 & 248.8 & 251.4 & 254.0 & 256.6 & 259.2 & 261.8 & 264.5 \\
\hline 4.0 & 267.1 & 269.8 & 272.5 & 275.3 & 278.0 & 280.8 & 283.6 & 286.4 & 289.3 & 292.1 \\
\hline 4.1 & 295.0 & & & & & & & & & \\
\hline
\end{tabular}

Offset ${ }^{*}=0.32$

"Offset is the difference between the staff gage reading and stage at zero flow. 
Table D.18 Rating table for the short-crested V-notch weir at the Northwest Tributary (NWT, GS4, USGS 03536440) station located above the confluence with First Creek

\begin{tabular}{|c|c|c|c|c|c|c|c|c|c|c||}
\hline $\begin{array}{c}\text { GAGE } \\
\text { HEIGHT } \\
\text { (ft) }\end{array}$ & \multicolumn{10}{|c|}{$\begin{array}{c}\text { DISCHARGE } \\
\text { (cfs) }\end{array}$} \\
\hline & 0.00 & 0.01 & 0.02 & 0.03 & 0.04 & 0.05 & 0.06 & 0.07 & 0.08 & 0.09 \\
\hline \hline 0.2 & .100 & .113 & .127 & .142 & .158 & .175 & .193 & .212 & .233 & .254 \\
\hline 0.3 & .277 & .300 & .325 & .351 & .379 & .407 & .437 & .468 & .501 & .534 \\
\hline 0.4 & .569 & .606 & .643 & .683 & .723 & .765 & .808 & .853 & .899 & .947 \\
\hline 0.5 & .996 & 1.05 & 1.10 & 1.15 & 1.21 & 1.27 & 1.32 & 1.38 & 1.45 & 1.51 \\
\hline 0.6 & 1.57 & 1.64 & 1.71 & 1.78 & 1.85 & 1.92 & 2.00 & 2.08 & 2.16 & 2.24 \\
\hline 0.7 & 2.32 & 2.40 & 2.49 & 2.58 & 2.66 & 2.76 & 2.85 & 2.94 & 3.04 & 3.14 \\
\hline 0.8 & 3.24 & 3.34 & 3.45 & 3.55 & 3.66 & 3.77 & 3.89 & 4.00 & 4.12 & 4.23 \\
\hline 0.9 & 4.35 & 4.48 & 4.60 & 4.73 & 4.86 & 4.99 & 5.12 & 5.25 & 5.39 & 5.53 \\
\hline 1 & 5.67 & 5.82 & 5.96 & 6.11 & 6.26 & 6.41 & 6.57 & 6.72 & 6.88 & 7.04 \\
\hline 1.1 & 7.20 & 7.37 & 7.54 & 7.71 & 7.88 & 8.05 & 8.23 & 8.41 & 8.59 & 8.78 \\
\hline 1.2 & 8.96 & 9.15 & 9.34 & 9.54 & 9.73 & 9.93 & 10.13 & 10.33 & 10.54 & 10.75 \\
\hline 1.3 & 10.96 & 11.17 & 11.38 & 11.60 & 11.82 & 12.04 & 12.27 & 12.50 & 12.73 & 12.96 \\
\hline 1.4 & 13.19 & 13.43 & 13.67 & 13.92 & 14.16 & 14.41 & 14.66 & 14.91 & 15.17 & 15.43 \\
\hline 1.5 & 15.69 & 15.95 & 16.22 & 16.49 & 16.76 & 17.03 & 17.31 & 17.59 & 17.87 & 18.16 \\
\hline 1.6 & 18.45 & 18.74 & 19.03 & 19.33 & 19.62 & 19.93 & 20.23 & 20.54 & 20.85 & 21.16 \\
\hline 1.7 & 21.48 & 21.79 & 22.12 & 22.44 & 22.77 & 23.10 & 23.43 & 23.76 & 24.10 & 24.44 \\
\hline & & & & & & & & & \\
\hline
\end{tabular}


Table D.18 (continued)

\begin{tabular}{|c|c|c|c|c|c|c|c|c|c|c|}
\hline \multirow{2}{*}{$\begin{array}{l}\text { GAGE } \\
\text { HEIGHT } \\
\text { (fi) }\end{array}$} & \multicolumn{10}{|c|}{$\begin{array}{c}\text { DISCHARGE } \\
\text { (cFs) }\end{array}$} \\
\hline & 0.00 & 0.01 & 0.02 & 0.03 & 0.04 & 0.05 & 0.06 & 0.07 & 0.08 & 0.09 \\
\hline 1.8 & 24.79 & 25.13 & 25.48 & 25.84 & 26.19 & 26.55 & 26.91 & 27.28 & 27.65 & 28.02 \\
\hline 1.9 & 28.39 & 28.77 & 29.14 & 29.53 & 29.91 & 30.30 & 30.69 & 31.09 & 31.48 & 31.88 \\
\hline 2 & 32.29 & 32.69 & 33.10 & 33.52 & 33.93 & 34.35 & 34.77 & 35.20 & 35.63 & 36.06 \\
\hline 2.1 & 36.49 & 36.93 & 37.37 & 37.82 & 38.26 & 38.71 & 39.17 & 39.62 & 40.08 & 40.54 \\
\hline 2.2 & 41.01 & 41.48 & 41.95 & 42.43 & 42.91 & 43.39 & 43.88 & 44.36 & 44.86 & 45.35 \\
\hline 2.3 & 45.85 & 46.35 & 46.86 & 47.37 & 47.88 & 48.39 & 48.91 & 49.43 & 49.96 & 50.49 \\
\hline 2.4 & 51.02 & 51.55 & 52.09 & 52.63 & 53.18 & 53.73 & 54.28 & 54.83 & 55.39 & 55.95 \\
\hline 2.5 & 56.52 & 57.09 & 57.66 & 58.24 & 58.82 & 59.40 & 59.88 & 60.57 & 61.17 & 61.76 \\
\hline 2.6 & 62.36 & 62.97 & 63.57 & 64.18 & 64.80 & 65.42 & 66.04 & 66.66 & 67.29 & 67.92 \\
\hline 2.7 & 68.56 & 69.20 & 69.84 & 70.48 & 71.13 & 71.79 & 72.44 & 73.10 & 73.77 & 74.44 \\
\hline 2.8 & 75.11 & 75.78 & 76.46 & 77.14 & 77.83 & 78.52 & 79.21 & 79.91 & 80.61 & 81.31 \\
\hline 2.9 & 82.02 & 82.73 & 83.45 & 84.17 & 84.89 & 85.61 & 86.34 & 87.08 & 87.82 & 88.56 \\
\hline 3 & 89.30 & 90.05 & 90.80 & 91.56 & 92.32 & 93.08 & 93.85 & 94.62 & 95.40 & 96.18 \\
\hline 3.1 & 96.96 & 97.75 & 98.54 & 99.33 & 100.1 & 100.9 & 101.7 & 102.5 & 103.4 & 104.2 \\
\hline 3.2 & 105.0 & 105.8 & 106.6 & 107.4 & 108.2 & 109.0 & 109.8 & 110.6 & 111.4 & 112.2 \\
\hline 3.3 & 113.0 & 113.9 & 114.7 & 115.5 & 116.3 & 117.2 & 118.0 & 118.9 & 119.7 & 120.6 \\
\hline 3.4 & 121.4 & 122.3 & 123.1 & 124.0 & 125.7 & 127.3 & 129.0 & 130.7 & 132.4 & 134.2 \\
\hline
\end{tabular}


Table D.18 (continued)

\begin{tabular}{|c|c|c|c|c|c|c|c|c|c|c||}
\hline $\begin{array}{c}\text { GAGE } \\
\text { HEIGHT } \\
\text { (ft) }\end{array}$ & \multicolumn{9}{|c|}{$\begin{array}{c}\text { DISCHARGE } \\
\text { (cfs) }\end{array}$} \\
\hline \hline & 0.00 & 0.01 & 0.02 & 0.03 & 0.04 & 0.05 & 0.06 & 0.07 & 0.08 & 0.09 \\
\hline \hline 3.5 & 135.9 & 137.7 & 139.5 & 141.3 & 143.1 & 145.0 & 146.9 & 148.7 & 150.6 & 152.6 \\
\hline 3.6 & 154.5 & 156.5 & 158.4 & 160.4 & 162.5 & 164.5 & 166.6 & 168.6 & 170.7 & 172.9 \\
\hline 3.7 & 175.0 & 177.4 & 179.8 & 182.2 & 184.7 & 187.2 & 189.7 & 192.2 & 194.8 & 197.4 \\
\hline 3.8 & 200.0 & & & & & & & & & \\
\hline
\end{tabular}


Table D.22 Rating table for the H-flume at Center Seven station (GS17, USGS 03537200) located on the center tributary to Melton Branch adjacent to SWSA 7

\begin{tabular}{|c|c|c|c|c|c|c|c|c|c|c|}
\hline \multirow{2}{*}{$\begin{array}{c}\text { GAGE } \\
\text { HEIGHT } \\
\text { (it) } \\
\end{array}$} & \multicolumn{10}{|c|}{$\begin{array}{l}\text { DISCHARGE } \\
\text { (cfs) }\end{array}$} \\
\hline & 0.00 & 0.01 & 0.02 & 0.03 & 0.04 & 0.05 & 0.06 & 0.07 & 0.08 & 0.09 \\
\hline 1.0 & .000 & .001 & .003 & .004 & .006 & .007 & .009 & .012 & .016 & .022 \\
\hline 1.1 & .029 & .034 & .039 & .045 & .051 & .057 & .064 & .072 & .080 & .087 \\
\hline 1.2 & .094 & .102 & .111 & .120 & .129 & .138 & .149 & .160 & .169 & .179 \\
\hline 1.3 & .190 & .201 & .212 & .224 & .237 & .250 & .263 & .277 & .291 & .305 \\
\hline 1.4 & .321 & .337 & .354 & .371 & .389 & .408 & .428 & .448 & .470 & .492 \\
\hline 1.5 & .515 & .539 & .564 & .585 & .607 & .630 & .653 & .677 & .701 & .726 \\
\hline 1.6 & .753 & .779 & .807 & .835 & .865 & .895 & .926 & .957 & .990 & 1.02 \\
\hline 1.7 & 1.06 & 1.09 & 1.13 & 1.16 & 1.19 & 1.23 & 1.26 & 1.30 & 1.33 & 1.37 \\
\hline 1.8 & 1.41 & 1.44 & 1.48 & 1.52 & 1.56 & 1.61 & 1.65 & 1.69 & 1.73 & 1.78 \\
\hline 1.9 & 1.83 & 1.87 & 1.92 & 1.97 & 2.01 & 2.06 & 2.11 & 2.15 & 2.20 & 2.25 \\
\hline 2.0 & 2.30 & 2.36 & 2.41 & 2.46 & 2.51 & 2.56 & 2.62 & 2.67 & 2.73 & 2.78 \\
\hline 2.1 & 2.84 & 2.89 & 2.95 & 3.01 & 3.07 & 3.13 & 3.19 & 3.26 & 3.32 & 3.38 \\
\hline 2.2 & 3.45 & 3.52 & 3.58 & 3.65 & 3.72 & 3.79 & 3.86 & 3.93 & 4.01 & 4.08 \\
\hline 2.3 & 4.16 & 4.23 & 4.31 & 4.39 & 4.47 & 4.55 & 4.63 & 4.72 & 4.80 & 4.89 \\
\hline 2.4 & 4.97 & 5.06 & 5.14 & 5.22 & 5.30 & 5.38 & 5.46 & 5.54 & 5.63 & 5.71 \\
\hline 2.5 & 5.80 & 5.89 & 5.97 & 6.06 & 6.15 & 6.24 & 6.33 & 6.43 & 6.52 & $6.61^{\circ}$ \\
\hline 2.6 & 6.71 & 6.81 & 6.90 & 7.00 & 7.10 & 7.20 & 7.30 & 7.41 & 7.51 & 7.61 \\
\hline
\end{tabular}


Table D.22 (continued)

\begin{tabular}{|c|c|c|c|c|c|c|c|c|c|c|}
\hline \multirow{2}{*}{$\begin{array}{c}\text { GAGE } \\
\text { HEIGHT } \\
\text { (f) }\end{array}$} & \multicolumn{10}{|c|}{$\begin{array}{l}\text { DISCHARGE } \\
\text { (cfs) }\end{array}$} \\
\hline & 0.00 & 0.01 & 0.02 & 0.03 & 0.04 & 0.05 & 0.06 & 0.07 & 0.08 & 0.09 \\
\hline 2.7 & 7.72 & 7.83 & 7.94 & 8.04 & 8.15 & 8.27 & 8.38 & 8.49 & 8.61 & 8.72 \\
\hline 2.8 & 8.84 & 8.96 & 9.08 & 9.20 & 9.32 & 9.44 & 9.56 & 9.69 & 9.81 & 9.94 \\
\hline 2.9 & 10.07 & 10.20 & 10.34 & 10.48 & 10.62 & 10.76 & 10.91 & 11.05 & 11.20 & 11.35 \\
\hline 3.0 & 11.50 & 11.63 & 11.76 & 11.90 & 12.03 & 12.16 & 12.30 & 12.44 & 12.58 & 12.72 \\
\hline 3.1 & 12.86 & 13.00 & 13.14 & 13.28 & 13.43 & 13.58 & 13.72 & 13.87 & 14.02 & 14.17 \\
\hline 3.2 & 14.32 & 14.47 & 14.63 & 14.78 & 14.94 & 15.10 & 15.26 & 15.42 & 15.58 & 15.74 \\
\hline 3.3 & 15.90 & 16.07 & 16.23 & 16.40 & 16.57 & 16.74 & 16.91 & 17.08 & 17.25 & 17.42 \\
\hline 3.4 & 17.60 & 17.78 & 17.97 & 18.16 & 18.34 & 18.53 & 18.72 & 18.92 & 19.11 & 19.30 \\
\hline 3.5 & 19.50 & 20.09 & 20.71 & 21.33 & 21.98 & 22.64 & 23.32 & 24.02 & 24.74 & 25.47 \\
\hline 3.6 & 26.23 & 27.01 & 27.81 & 28.63 & 29.47 & 30.33 & 31.22 & 32.13 & 33.06 & 34.02 \\
\hline 3.7 & 35.00 & 35.48 & 35.96 & 36.44 & 36.94 & 37.43 & 37.94 & 38.44 & 38.96 & 39.48 \\
\hline 3.8 & 40.00 & & & & & & & & & \\
\hline
\end{tabular}

Offset $^{\circ}=1.00$

"Offset is the difference between the staff gage reading and stage at zero flow. 
Table D.25 Rating table for East Fork and West Fork weirs located on Walker Branch in the Walker Branch Watershed

\begin{tabular}{|c|c|c|c|c|c|c|c|c|c|c|}
\hline \multirow{2}{*}{$\begin{array}{c}\text { GAGE } \\
\text { HEIGHT } \\
\text { (ft) } \\
\end{array}$} & \multicolumn{10}{|c|}{$\begin{array}{l}\text { DISCHARGE } \\
\text { (cfs) }\end{array}$} \\
\hline & 0.00 & 0.01 & 0.02 & 0.03 & 0.04 & 0.05 & 0.06 & 0.07 & 0.08 & 0.09 \\
\hline 0.2 & 0.086 & 0.097 & 0.109 & 0.121 & 0.135 & 0.149 & 0.164 & 0.180 & 0.196 & 0.214 \\
\hline 0.3 & 0.232 & 0.252 & 0.272 & 0.294 & 0.316 & 0.339 & 0.363 & 0.388 & 0.415 & 0.442 \\
\hline 0.4 & 0.470 & 0.499 & 0.530 & 0.561 & 0.594 & 0.627 & 0.662 & 0.698 & 0.735 & 0.773 \\
\hline 0.5 & 0.812 & 0.852 & 0.894 & 0.937 & 0.980 & 1.026 & 1.072 & 1.119 & 1.168 & 1.218 \\
\hline 0.6 & 1.269 & 1.322 & 1.375 & 1.430 & 1.486 & 1.544 & 1.603 & 1.663 & 1.724 & 1.787 \\
\hline 0.7 & 1.851 & 1.917 & 1.983 & 2.052 & 2.121 & 2.192 & 2.264 & 2.338 & 2.413 & 2.489 \\
\hline 0.8 & 2.567 & 2.647 & 2.727 & 2.809 & 2.893 & 2.978 & 3.065 & 3.153 & 3.242 & 3.333 \\
\hline 0.9 & 3.426 & 3.520 & 3.615 & 3.712 & 3.811 & 3.911 & 4.012 & 4.115 & 4.220 & 4.326 \\
\hline 1 & 4.434 & 4.543 & 4.654 & 4.767 & 4.881 & 4.997 & 5.114 & 5.233 & 5.354 & 5.476 \\
\hline 1.1 & 5.600 & 5.725 & 5.852 & 5.981 & 6.112 & 6.244 & 6.378 & 6.513 & 6.650 & 6.789 \\
\hline 1.2 & 6.930 & 7.072 & 7.216 & 7.362 & 7.509 & 7.658 & 7.809 & 7.962 & 8.116 & 8.272 \\
\hline 1.3 & 8.430 & 8.590 & 8.751 & 8.915 & 9.080 & 9.247 & 9.415 & 9.586 & 9.758 & 9.932 \\
\hline 1.4 & 10.108 & 10.286 & 10.465 & 10.647 & 10.830 & 11.015 & 11.202 & 11.391 & 11.582 & 11.774 \\
\hline 1.5 & 11.969 & 12.165 & 12.363 & 12.563 & 12.765 & 12.969 & 13.175 & 13.383 & 13.593 & 13.804 \\
\hline 1.6 & 14.018 & 14.234 & 14.451 & 14.670 & 14.892 & 15.115 & 15.341 & 15.568 & 15.797 & 16.028 \\
\hline 1.7 & 16.262 & 16.497 & 16.734 & 16.973 & 17.215 & 17.458 & 17.703 & 17.951 & 18.200 & 18.452 \\
\hline 1.8 & 18.705 & 18.961 & 19.218 & 19.478 & 19.739 & 20.003 & 20.269 & 20.537 & 20.807 & 21.079 \\
\hline
\end{tabular}


Table D.25 (continued)

\begin{tabular}{||c|c|c|c|c|c|c|c|c|c|c||}
\hline $\begin{array}{c}\text { GAGE } \\
\text { HEIGHT } \\
\text { (ft) }\end{array}$ & \multicolumn{10}{|c|}{$\begin{array}{c}\text { DISCHARGE } \\
\text { (cfs) }\end{array}$} \\
\hline & 0.00 & 0.01 & 0.02 & 0.03 & 0.04 & 0.05 & 0.06 & 0.07 & 0.08 & 0.09 \\
\hline \hline 1.9 & 21.353 & 21.629 & 21.908 & 22.188 & 22.471 & 22.756 & 23.043 & 23.332 & 23.623 & 23.916 \\
\hline 2 & 24.211 & 24.509 & 24.809 & 25.110 & 25.414 & 25.721 & 26.029 & 26.339 & 26.652 & 26.967 \\
\hline 2.1 & 27.284 & 27.603 & 27.925 & 28.249 & 28.575 & 28.903 & 29.233 & 29.566 & 29.900 & 30.237 \\
\hline 2.2 & 30.577 & 30.918 & 31.262 & 31.608 & 31.956 & 32.307 & 32.659 & 33.014 & 33.372 & 33.731 \\
\hline 2.3 & 34.093 & 34.457 & 34.824 & 35.193 & 35.564 & 35.937 & 36.313 & 36.691 & 37.071 & 37.453 \\
\hline 2.4 & 37.838 & 38.226 & 38.615 & 39.007 & 39.402 & 39.798 & 40.197 & 40.599 & 41.002 & 41.408 \\
\hline 2.5 & 41.817 & & & & & & & & & \\
\hline
\end{tabular}




\section{DISTRIBUTION}

1. L. J. Allison

2. L. D. Bates

3. F. P. Baxter

4. B. A. Berven

5-9. D. M. Borders

10. H. L. Boston

11. N. Bowden

12. A. L. Brenkert

13. B. A. Bryan

14. R. B. Clapp

15. P. M. Craig

16. J. H. Cushman

17. V. H. Dale

18. T. A Fontaine

19. C. J. Ford

20. D. E. Fowler

21-25. B. J. Frederick

26. S. M. Gregory

27. R. K. Gryder

28. A. L. Halleran

29. S. E. Herbes

30. D. S. Hicks

31. S. G. Hildebrand

32. W. R. Hill

33. R. L. Hinzman

34. D. D. Huff

35. M. A. Huston

36. E. J. Jackson

37. P. Kanciruk

38. R. H. Ketelle

39. B. L. Kimmel

40. R. H. Kingrea

41. A. J. Kuhaida

42. J. M. Loar

43. J. D. Marsh

44-46. D. M. Matteo

47-51. W. L. McCalla
52. T. D. Moore

53. C. M. Morrissey

54. P. J. Mulholland

55. J. B. Murphy

56-57. P. T. Owen

58. D. J. Pridmore

59-63. D. K. Reece

64. D. E. Reichle

65. R. M. Rush

66. W. E. Sanford

67. P. A. Schrandt

68. J. A. Shaakir-Ali

69. F. E. Sharples

70. D. S. Shriner

71. M. M. Stevens

72. A. J. Stewart

73. S. H. Stow

74. M. F. Tardiff

75. A. L. Thomas

76. L. E. Toran

77. C. K. Valentine

78. D. R. Watkins

79-83. J. A. Watts

84. S. A. White

85. R. F. Winterfield

86. S. L Winters

87. D. A. Wolf

88. P. S. Wood

89-93. K S. Ziegler

94. T. F. Zondlo

95. ORNL Patent Section

96. Central Research Library

97-111. ESD Library

112. ORNL Y-12 Technical Library

113-115. ORNL ER Doc. Mgmt. Center

116-118. Central ER Doc. Mgmt. Center

119. Laboratory Records Department

120. Office of Assistant Manager for Energy Research and Development, DOE Oak Ridge Operations Office, P.O. Box 2001, Oak Ridge, TN 37831-8600

121. S. A. Blair, Ogden Env. \& Energy Services, 1009 Commerce Park, Suite 100, Oak Ridge, TN 37830

122. G. W. Bodenstein, DOE Federal Bldg. Rm. 2115, Oak Ridge, TN 37830

123. R. N. Farvolden, Professor, Department of Earth Sciences, University of Waterloo, Waterloo, Ontario N2L 3G1 Canada

124. D. W. Freckman, Director, College of Natural Resources, 101 Natural Resources Building, Colorado State University, Fort Collins, CO 80523

125. G. Y. Jordy, Director, Office of Program Analysis, Office of Energy Research, ER-30, G-226, U.S. Department of Energy, Washington, D.C. 20545 
126. A. Patrinos, Director, Environmental Sciences Division, Office of Health and Environmental Research, ER-74, U.S. Department of Energy, Washington, D.C. 20585

127. G. S. Sayler, Professor, 10515 Research Drive, Suite 100, The University of Tennessee, Knoxville, TN 37932-2567

128. J. D. Weaver, USGS, 810 Broadway, Suite 500, Nashville, TN 37203

129. F. J. Wobber, Environmental Sciences Division, Office of Health and Environmental Research, ER-74, U.S. Department of Energy, Washington, D.C. 20585

130. V. Yucel, Bechtel National Inc., 151 Lafayette Dr., Oak Ridge, TN 37830

131-132. Office of Scientific and Technical Information, P.O. Box 62, Oak Ridge, TN 37831 